REGINA STELA CORRÊA VIEIRA

\title{
O CUIDADO COMO TRABALHO: \\ uma interpelação do Direito do Trabalho a partir da perspectiva de gênero
}

\author{
Tese de Doutorado \\ Orientador: Prof. Dr. Homero Batista Mateus da Silva
}

UNIVERSIDADE DE SÃO PAULO

FACULDADE DE DIREITO

São Paulo - SP

2018 



\title{
REGINA STELA CORRÊA VIEIRA
}

\section{O CUIDADO COMO TRABALHO: \\ uma interpelação do Direito do Trabalho a partir da perspectiva de gênero}

\begin{abstract}
Tese apresentada à Banca Examinadora do Programa de Pós-Graduação em Direito, da Faculdade de Direito da Universidade de São Paulo, como requisito parcial para obtenção do título de Doutora em Direito, na área de concentração Direito do Trabalho e da Seguridade Social, sob a orientação do Prof. Dr. Homero Batista Mateus da Silva.
\end{abstract}

Versão corrigida em 22/10/2018. A versão original, em formato eletrônico (PDF), encontra-se disponível na CPG da Unidade

São Paulo - SP 
Catalogação da Publicação

Serviço de Biblioteca e Documentação

Faculdade de Direito da Universidade de São Paulo

Vieira, Regina Stela Corrêa.

Cuidado como trabalho: uma interpelação do Direito do Trabalho a partir da perspectiva de gênero / Regina Stela Corrêa Vieira; orientador Homero Batista Mateus da Silva - São Paulo, 2018.

$236 \mathrm{p}$.

Tese (Doutorado - Programa de Pós-Graduação em Direito, Área de Concentração Direito do Trabalho e da Seguridade Social), Faculdade de Direito, Universidade de São Paulo, 2018 .

1. Teoria Feminista do Direito do Trabalho. 2. Crítica jurídica. 3. Cuidado. 4. Trabalho doméstico. 5. Trabalho e gênero. I. Silva, Homero Batista Mateus, orient. II. Título. 
VIEIRA, Regina Stela Corrêa. Cuidado como trabalho: uma interpelação do Direito do Trabalho a partir da perspectiva de gênero. 2018. 236 p. Tese (Doutorado em Direito) Faculdade de Direito, Universidade de São Paulo, São Paulo, 2018.

Aprovada, com louvor, distinção e recomendação para publicação em 24 ago. 2018.

\section{BANCA EXAMINADORA}

Profa. Dra. Helena Hirata

Instituição: Centre de Recherches Sociologiques et Politiques de Paris

Julgamento: Aprovada

Prof. Dr. $\quad$ Pedro Augusto Gravatá Nicoli

Instituição: Universidade Federal de Minas Gerais

Julgamento: Aprovada

Profa. Dra. Patrícia Tuma Martins Bertolin

Instituição: Universidade Presbiteriana Mackenzie

Julgamento: Aprovada

Prof. Assoc. Jorge Luiz Souto Maior

Instituição: Universidade de São Paulo

Julgamento: Aprovada

Prof. Tit. Gilberto Bercovici

Instituição: Universidade de São Paulo

Julgamento: Aprovada 

Para as pessoas incriveis que tive a honra de conhecer ao longo desta pesquisa, em especial Eliete, Kota e Regina. 



\section{AGRADECIMENTOS}

À Faculdade de Direito da Universidade de São Paulo, pela oportunidade de realização da graduação, mestrado e doutorado em uma instituição pública de excelência.

Ao Prof. Homero Batista Mateus da Silva, que nos anos de convivência muito contribuiu para meu desenvolvimento acadêmico.

À Fundação de Amparo à Pesquisa do Estado de São Paulo (FAPESP), pela concessão da bolsa de doutorado no país (Processo $n^{\circ}$ 2016/18865-6) e da bolsa de estágio de pesquisa no exterior (BEPE Processo $n^{\circ}$ 2017/00743-4), dando apoio à realização desta pesquisa.

À Profa. Helena Hirata, que cotidianamente inspira e ensina, pela supervisão do estágio doutoral, pela participação na banca examinadora e pelo suporte em todos os momentos.

Ao Centre de Recherches Sociologiques et Politiques de Paris, equipe Genre, Travail, Mobilités, em nome de sua diretora, Profa. Carole Brugeilles, pelo acolhimento no estágio doutoral.

Ao Prof. Pedro Augusto Gravatá Nicoli, por toda a atenção, ajuda e brilho que tocam meu caminho desde nosso encontro no II Seminário Internacional Desfazendo o Gênero, pela participação na banca de qualificação, na banca avaliadora da tese e por me apresentar os estudos feministas do Direito do Trabalho.

À Profa. Patricia Tuma Martins Bertolin, precursora, pelo apoio constante e pela participação na banca de qualificação e na banca avaliadora deste doutorado.

Ao Prof. Jorge Luiz Souto Maior, referência no Largo São Francisco desde meu primeiro ano de graduação, por ser exemplo e amparo para muitas e muitos como eu, e por sua participação na banca avaliadora.

À Profa. Judy Fudge e à Profa. Cristina Carrasco, que tiveram tempo de me receber para debater alguns pontos desta tese.

Aos professores Flávio Roberto Batista, Samuel Rodrigues Barbosa e Tarso de Melo, em nome dos quais agradeço aos professores e professoras presentes em minha trajetória, que gentilmente oferecem alento e incentivo.

À Bruna Angotti, companheira e parceira, por ter ouvido, lapidado e incentivado toda a pesquisa - a ponto de trazer um livro do Canadá e levar de volta! - e, ainda, pela revisão na reta final.

À Juliana Miasso, amiga de vida, sem a qual não teria conseguido passar a temporada de estudos em Paris, fase tão importante para esta pesquisa seguir em frente.

Ao Marco Antonio Almeida Ruiz, pelo incansável suporte e pela revisão atenta destas páginas.

À Cecilia Ugartemendía e Eduardo Saad Diniz, pelo auxílio em cada etapa e atenção sempre que precisei de ajuda. 
À Fabiana Sanches Grecco, que esteve comigo em momentos singulares da pesquisa, como nas entrevistas com Cristina Carrasco e Betânia Ávila, e em especial por me ajudar a interpretar as críticas da Profa. Bila Sorj como impulso para as conclusões da tese.

À Sarah de Roure, que me apresentou Cristina Carrasco e Silvia Federici.

Ao Núcleo Direito e Democracia do CEBRAP, em nome de Marcos Nobre, e em especial ao seu grupo de mulheres, que me permitiu viver uma construção cientifica que é coletiva e solidária, que pode ser compartilhada e prazerosa. Aqui nomeio Luciana Reis, Daniela Rozados, Elaini Silva, Fabíola Fanti, Gabriela Justino e Evorah Cardoso.

Ao Grupo de Pesquisa Trabalho e Capital, em nome de Giovanna Magalhães, Valdete Souto Severo e Gustavo Seferian.

À Juliana Bueno, que me deu apoio enquanto lecionei disciplina da UnB, já na metade desta pesquisa.

À Sabrina Marques, que abriu as portas para a entrevista com a Deputada Benedita da Silva e botou fé nas minhas aulas na UnB.

Ao Flávio Fleury, em nome de quem agradeço as/os estudantes que passaram pelas minhas aulas e que tanto me ensinaram.

À Leila Giovana Izidoro, pelo grande auxílio nas transcrições das entrevistas.

A Renan Quinalha, Thiago Barison, Daniela Vieira, Anna Paula Vencato, Murilo Vanucci, Flávio Higa, Mariana Valente, Natália Neris, Marina Ruzzi e a todas as amigas e amigos pelo apoio.

À Alexandra Elbakyan, criadora do Sci-hub, em nome de quem agradeço todas as ferramentas que democratizam o acesso a livros e artigos científicos.

A todas as entrevistadas, pelo tempo que dispuseram para enriquecer esta pesquisa.

Ao Sindicato das Trabalhadoras Domésticas de Campinas, em nome de Eliete, Regina e Kota, pelo acolhimento e por fazerem diferença no Brasil.

A todas as trabalhadoras e trabalhadores da FDUSP, que faço em nome de Cristiana Miranda e Mariene dos Santos, do DTBS, de toda a Secretaria da Pós-Graduação e de Maria Lúcia Castro, que nos deixou na reta final desta tese.

À Patricia e equipe do CTC Soluções Gráficas, que com toda atenção cuidou da impressão desta tese.

À minha tia Luiza Regina Corrêa, que me iniciou no mundo das letras e palavras.

À minha família - Barbara Corrêa, Carlos Vieira e Raquel Vieira -, sem a qual eu não teria começado, que entendeu cada minuto distante e que me ensinou o sentido do cuidar.

Ao Marco Braga, por estar ao meu lado e acreditar no meu trabalho sem pestanejar; por ser alicerce pra ficar, vento pra voar; por tudo. 
"Se va enredando, enredando

Como en el muro la hiedra

$Y$ va brotando, brotando

Como el musguito en la piedra"

(Violeta Parra, 1966) 



\section{RESUMO}

VIEIRA, Regina Stela Corrêa. Cuidado como trabalho: uma interpelação do Direito do Trabalho a partir da perspectiva de gênero. 2018. 236 p. Doutorado - Faculdade de Direito, Universidade de São Paulo, São Paulo, 2018.

A pesquisa analisa a exclusão da categoria cuidado das noções de trabalho presentes no Direito do Trabalho brasileiro e seu papel na criação de barreiras para a igualdade entre mulheres e homens. Partindo da constatação das desigualdades de gênero presentes no mundo do trabalho na atualidade e entendendo o cuidado como um nó central para compreender as relações de exploração e opressão às quais estão submetidas as mulheres, a proposta é olhar para o Direito do Trabalho como um ator que interfere neste processo, de forma a revisitar suas bases teóricas e categorias fundamentais, com o objetivo de testar a hipótese de que o conceito de trabalho presente na legislação trabalhista é masculino e excludente, ampliando barreiras no processo de promoção da igualdade. As reflexões teóricas acerca da conceituação e escopo do Direito do Trabalho, a partir de uma perspectiva de gênero, têm como base o pensamento acerca do cuidado já elaborado por autoras da sociologia do trabalho e da economia feminista e os fundamentos da teoria do Direito do Trabalho e da teoria feminista do Direito. As reflexões teóricas, feitas em conjunto com a elaboração de panorama da inserção do cuidado e os diretos a ele relativos no ordenamento jurídico nacional, têm apoio empírico na análise históricodocumental do processo legislativo de positivação de direitos relacionados ao cuidado na legislação trabalhista - especificamente na gênese da Consolidação das Leis do Trabalho (CLT) e na reforma decorrente da promulgação da Constituição de 1988 -, bem como em entrevistas com integrantes de movimentos e organizações de mulheres e sindicais que abordam o cuidado como pauta de mobilização e o articulam com demandas por alterações no quadro normativo nacional.

Palavras-chave: teoria feminista do Direito do Trabalho; crítica jurídica; cuidado; trabalho doméstico; trabalho e gênero. 



\begin{abstract}
Vieira, Regina Stela Corrêa. Care as labour: an interpellation of Labour Law from a gender perspective. 2018. 236 p. Doctorate - Faculty of Law, University of São Paulo, São Paulo, 2018.

The research analyses the exclusion of the category Care from the labour notions set forth in the Brazilian labour law and its role in creating barriers to women and men equality. Based on the observation of the existence of gender inequalities in the labour market nowadays and taking Care as a central nub to understand the exploitation and oppression relations to which women have constantly been subjected to, the proposal is to look at the labour law as an actor that interferes in this process, in a way that revisits its theoretical and fundamental categories, in order to test the hypothesis that the labour concept in labour law is masculine and exclusionary, increasing barriers to the process of promoting equality. From a gender perspective, the theoretical reflections on the labour law concept and their scope are based on the reflections of Care which have already been developed by the sociology of labour and feminist economics authors on the labour law theory and feminist legal theory fundamentals. The theoretical reflections, made in conjunction with a panorama about the insertion of Care and Care rights of the legal system, have empirical support in the historical and documentary analysis of the legislative process involving labour law rights related to Care - specifically the genesis of the Labour Code (CLT) and reform resulting from the enactment of the 1988 Brazilian Constitution - as well as in some interviews with women's and unions' movements and organizations which include Care on their mobilization agenda and articulate it with the growing demand for changes in the national legal framework.
\end{abstract}

Keywords: feminist labour law scholarship; legal critique; care; domestic labour; labour and gender. 



\section{RÉSUMÉ}

Vieira, Regina Stela Corrêa. Care en tant que travail: une interpellation du Droit du Travail à partir d'une perspective de genre. 2018. 236 p. Doctorat - Faculté de Droit, Université de São Paulo, São Paulo, 2018

L'étude analyse l'exclusion du concept de care des notions de travail existantes dans le Droit du Travail brésilien, ainsi que son rôle dans la création d'obstacles à l'égalité entre les femmes et les hommes. À partir de l'observation des inégalités entre les sexes sur le marché du travail actuel, et en admettant la notion de care comme un nœud central pour comprendre les rapports d'exploitation et d'oppression auxquels les femmes sont soumises, la proposition de cette étude est d'analyser le Droit du Travail en tant qu'acteur interférant dans ce processus, de façon à revoir ses catégories théoriques et fondamentales. Le but est de tester l'hypothèse selon laquelle le concept de travail, dans la législation en question, est masculin et d'exclusion, ce qui augmente les barrières à la promotion de l'égalité. Les réflexions théoriques sont basées sur les études autour du concept de care développées par des auteurs de la Sociologie du Travail et de l'Économie Féministe, ainsi que sur les fondements de la théorie féministe du Droit du Travail. À cela s'ajoute l'élaboration d'un panorama de la notion de care et des droits concernés par elle dans le système juridique national - avec un support empirique sur l'analyse historique et documentaire du processus législatif de positivation des droits relatifs au concept de care dans la législation du travail, ainsi que sur des entretiens avec des membres de mouvements et d'organisations féministes et syndicaux qui traitent le concept de care comme «l'ordre du jour» de la mobilisation, tout en l'articulant avec des demandes de changements dans le cadre juridique national.

Mots-clés : théorie féministe du droit du travail; critique juridique; care; travail domestique; travail et genre. 



\section{SUMÁRIO}

INTRODUÇÃ

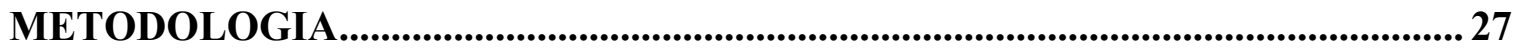

\section{CAPÍTULO 1}

Trabalho, gênero e cuidado: arcabouço interdisciplinar para análise ........................ 37

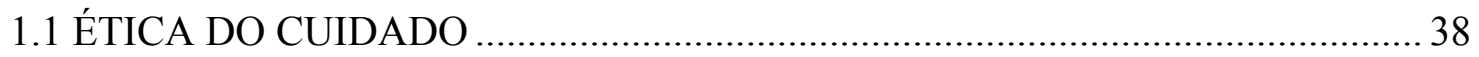

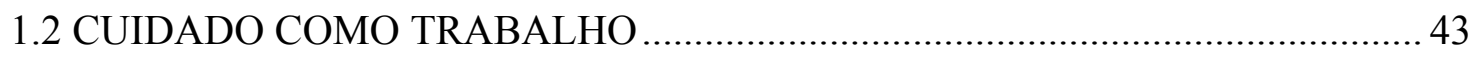

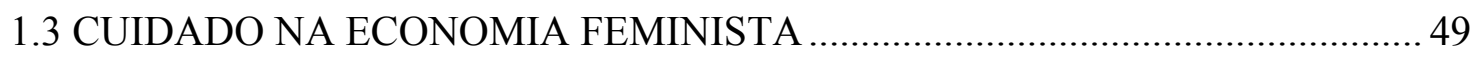

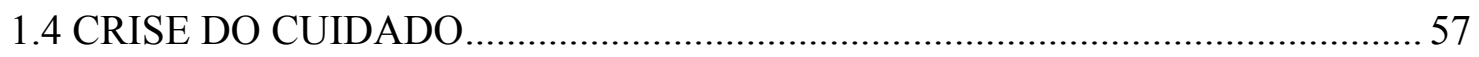

1.4.1 Cuidado no capitalismo financeiro globalizado .........................................5

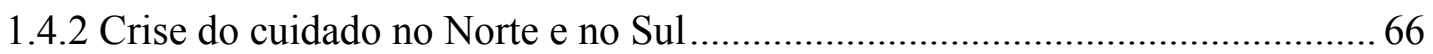

\section{CAPÍTULO 2}

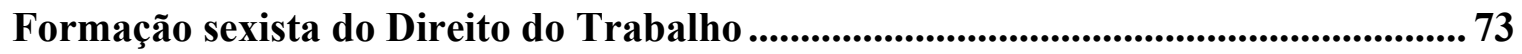

2.1 INTRODUÇÃO À TEORIA FEMINISTA DO DIREITO DO TRABALHO ....... 74

2.2 CRÍTICA À CONCEPÇÃO JURÍDICA DE ‘TRABALHO’ ................................. 79

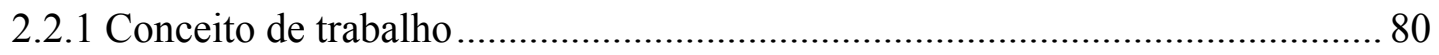

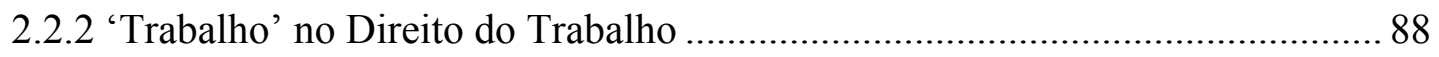

2.3 O CONTROVERSO MODELO DO TRABALHADOR UNIVERSAL .................97

2.4 O PARADIGMA DO TEMPO E AS FORMAS DE MENSURAÇÃO DO

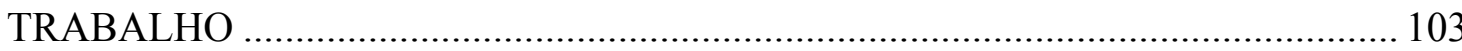

2.5 A CARGA DE GÊNERO CONTIDA NA NOÇÃO DE SALÁRIO ..................... 112

\section{CAPÍTULO 3}

Cuidado no Direito do Trabalho brasileiro.................................................................. 119

3.1 CONSIDERAÇÕES SOBRE O TRABALHO DE CUIDADO NO BRASIL....... 120

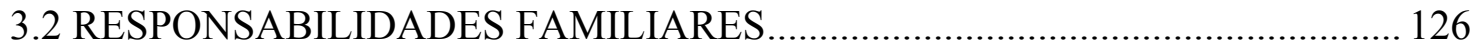

3.2.1 Intervalos, folgas e licenças para cuidado de filhas e filhos.......................... 129 
3.2.2 Direito à creche

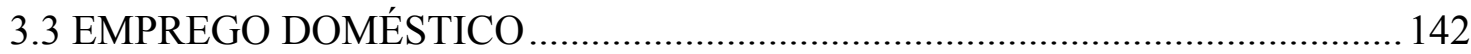

3.3.1 A exclusão do emprego doméstico da CLT e a Lei 5.859/1972 ..................... 144

3.3.2 Debates constituintes e os direitos das domésticas na Constituição de 1988.145

3.3.3 Passos até a Emenda Constitucional 72/2013 ........................................... 150

3.3.4 A regulamentação pela Lei Complementar 150/2015 …................................ 156

3.3.5 A organização das trabalhadoras domésticas enquanto categoria ................... 160

3.4 REGULAMENTAÇÃO DA PROFISSÃO DE CUIDADORA............................. 165

3.5 MERCANTILIZAÇÃO DO CUIDADO, FINANCEIRIZAÇÃO E REFORMA TRABALHISTA

\section{CAPÍTULO 4}

Rompimento e reconstrução de alicerces ..............................................................179

4.1 MARCAS DA SEGREGAÇÃO ENTRE TRABALHO E CUIDADO ................. 179

4.2 VIAS PARA REFORMULAÇÃO DO ESCOPO DA DISCIPLINA .................... 188

4.2.1 Justiça, responsabilidade e dependência..................................................... 189

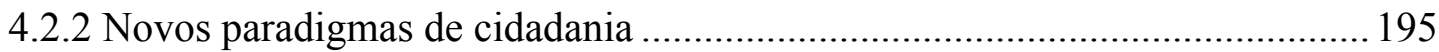

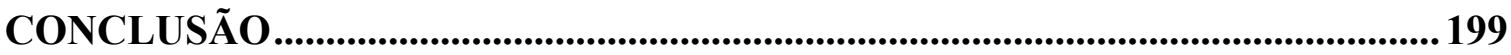

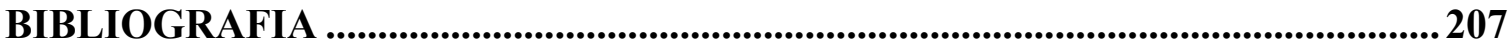

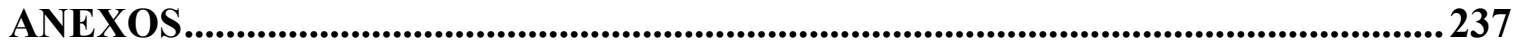




\section{INTRODUÇÃO}

O aumento da participação das mulheres no mercado de trabalho brasileiro, nas últimas décadas, não veio acompanhado de maior igualdade, tampouco maiores garantias e direitos para as trabalhadoras. Apesar de a taxa de atividade ${ }^{1}$ entre as mulheres ter uma significativa progressão, saindo de 18\% em 1970 (FCC, 2010) para 54,6\% em 2010, a diferença com relação aos homens ainda chama atenção, uma vez que a taxa de atividade deles no mesmo ano foi de 75,7\%, uma distância de mais de 20 pontos percentuais (IBGE, 2014, p. 108). Para a zona rural, esta diferença é ainda maior: a taxa de atividade dos homens foi de 72,2\%, mas de 45,5\% entre as mulheres (IBGE, 2014, p. 110).

Essa defasagem se mantém quando são analisadas as formas de inserção no mercado de trabalho por sexo. O período de 2000 a 2010 foi reconhecidamente de aumento da contratação formal, em que o número de pessoas empregadas passou de $50,5 \%$ para $58,6 \%$, todavia este crescimento foi inferior entre as mulheres: 6,6 pontos percentuais frente a 9,2 entre os homens (IBGE, 2014, p. 112). A distribuição no mercado de trabalho é também distinta: os homens concentram-se nos empregos com carteira assinada (46,5\%), no trabalho por conta própria $(24,7 \%)$ e informal $(17,1 \%)$; já mulheres estão em menor percentual nos empregos formais (39,8\%), também têm elevada alocação no trabalho por conta própria $(17,3 \%)$, mas possuem relevante concentração no emprego doméstico com ou sem carteira assinada $(15,1 \%)$ e no trabalho não remunerado $(2,1 \%)$ (IBGE, 2014, p. 114).

Somam-se a esse panorama a diferença entre as médias de horas semanais trabalhadas de homens e mulheres: em 2015, enquanto a jornada de trabalho remunerado deles era de 40,8 horas por semana, delas era de 34,9 horas, ou seja, inferior ao padrão de 8 horas diárias; já quanto ao tempo dedicado a afazeres domésticos, a média masculina é de 10 horas semanais, enquanto a feminina é de 20,5 horas (IBGE, 2016, p. 81). Isso significa que, a jornada total das mulheres é de 55,1 horas por semana, cinco a mais que a dos homens, equivalente a 50,5 (IBGE, 2016, p. 81).

Há ainda a defasagem de renda entre os sexos, uma vez que as mulheres recebem cerca de $76 \%$ do rendimento mensal dos homens (IBGE, 2016, p. 77), ou ainda a

\footnotetext{
${ }^{1}$ Que, conforme descrição do IBGE, mostra "a proporção da população em idade ativa que se encontra trabalhando ou procurando trabalho" (IBGE, 2014, p. 108).
} 
interferência gerada pela ausência de creches no nível de ocupação feminina - que é de $65,4 \%$ entre as mulheres com filhos de 0 a 3 anos que frequentam creches e de $41,2 \%$ entre aquelas cujos filhos não estão em creches (IBGE, 2014, p. 116). Tais números, quando dissecados por raça e região, apresentam discrepâncias ainda maiores.

Ademais, Lena Lavinas, Ana Carolina Cordilha e Gabriela Freitas da Cruz (2016, p. 101) apontam para a dimensão precária da inserção ocupacional na última década e seu impacto sobre as mulheres, tomando como exemplo a importância dos postos que remuneram até dois salários mínimos mensais no Brasil: entre 2006 e 2013, 84\% das admissões e $80 \%$ das demissões concentraram-se nessa faixa salarial, sendo que a proporção de vagas nesses postos de trabalho é maior para as mulheres - 88\% das mulheres contratadas no período, frente a $82 \%$ dos homens. Segundo as autoras, "a trajetória recente da economia brasileira (...) parece indicar que o desenvolvimento tal como vem ocorrendo é pouco amigável para as mulheres" (LAVINAS; CORDILHA; CRUZ, 2016, p. 108).

Esses dados revelam que a consolidação da presença feminina no mercado de trabalho não significou igualdade, uma vez que as mulheres permaneceram ocupando o segundo plano na sociedade, subordinadas à ideia de que o papel primordial feminino é o da manutenção do lar e da família. Além disso, caracterizam não apenas a desigualdade no modo de inserção das trabalhadoras, mas também a vulnerabilidade e precarização do trabalho feminino, em grande parte com alta rotatividade e redução dos direitos trabalhistas. Por conseguinte, nas palavras de Elisabeth Souza-Lobo (2011, p. 165), “a maior ou menor participação da mulher no mercado de trabalho não elimina a subordinação social das mulheres". ${ }^{2}$

Diversas áreas do conhecimento têm-se debruçado para compreender esse cenário de desigualdade e identificar as barreiras para as mulheres se estabelecerem como iguais no mundo do trabalho. ${ }^{3}$ A Teoria Feminista (FISHER; TRONTO, 1990; MOLINIER; LAUGIER; PAPERMAN, 2009; FRASER, 2016) e a Sociologia do Trabalho, do Gênero

\footnotetext{
${ }^{2}$ A precarização é válida para grande parte das trabalhadoras, contudo não para todas, vez que uma das tendências do trabalho assalariado feminino nas últimas décadas foi a bipolarização, ficando de um lado profissionais altamente qualificadas e com altos salários e, de outro, trabalhadoras expostas à precariedade (HIRATA, 2002).

3 "Mundo do trabalho" é uma expressão usual nos estudos do trabalho, empregada por autores como Eric J. Hobsbawn (2008), Ricardo Antunes (2008), Octavio Ianni (1994) e outros. Usa-se, aqui, para designar o universo do trabalho que contempla o mercado de trabalho, mas não se restringe a ele, assumindo um sentido mais amplo, a fim de incluir atividades não tradicionalmente consideradas "trabalho", especialmente o cuidado.
} 
e das Emoções (HOCHSCHILD, 1979, 2003; HIRATA; GUIMARÃES, 2012; ABREU; HIRATA; LOMBARDI, 2016) trazem grandes contribuições nas suas pesquisas voltadas à divisão sexual do trabalho e às formas de exercício das atividades relacionadas ao cuidado (ou care) pelas mulheres, além de abordarem debates sobre ética e teoria da justiça.

Outro enfoque, da Economia Feminista (CARRASCO, 1991, 2011; FEDERICI, 2012; FOLBRE, 2003), discute a invisibilidade do trabalho de cuidado e a necessidade do reconhecimento de seu papel central para a manutenção das condições de vida, desmascarando sua exploração pelo atual sistema econômico e colocando em questão o que se entende e como se mede riqueza e desenvolvimento na atual sociedade.

O ponto em comum dessas vertentes teóricas é que destacam o cuidado como variável central para a desigualdade de gênero e a complexa presença de mulheres no mercado de trabalho formal, uma vez que no sistema capitalista este tipo de atividade não é valorizada - e, por vezes, nem mesmo considerada "trabalho" -, gerando um grande desnível entre os sexos, pois o fardo de tais compromissos recai quase que exclusivamente sobre as mulheres. Ademais, colocam em cheque os paradigmas universais utilizados por diversas disciplinas ao longo de suas construções teóricas, lançando mão da perspectiva de gênero como meio de demonstrar que modelos de sujeito supostamente assexuados partem, em verdade, do estereótipo do homem (HIRATA; KERGOAT, 2008a, p. 44), o que se reflete na percepção das mulheres como desvio da norma.

O cuidado é um termo polissêmico, cujo conceito possui diversas dimensões e conflitos, podendo ter um significado mais amplo ou mais específico de acordo com a vertente. Utilizado para descrever "processos, relações e sentimentos entre pessoas que cuidam umas das outras", conota um campo de ações amplo e cobre várias dimensões da vida social, envolvendo desde "práticas, atitudes e valores relacionados com o afeto, o amor e a compaixão envolvidos nas relações intersubjetivas", até as ações do Estado e as políticas públicas voltadas aos segmentos da população tidos como dependentes (HIRATA; DEBERT, 2016, p. 7).

Apesar de o entendimento mais comum do cuidado estar relacionado às atividades de atenção a crianças, idosos e pessoas com deficiência, a multidimensionalidade do termo amplia esse escopo, colocando em questão, inclusive, a percepção do que é 
dependência para os seres humanos - uma vez que identificar determinados grupos como “dependentes” é ignorar que a dependência é inerente à condição humana, representativa da vulnerabilidade de todas as pessoas, que sempre demandarão cuidados, em níveis maiores ou menores dependendo da fase da vida (CARRASCO; BORDERÍAS; TORNS, 2011, p. 53).

No Brasil, a categoria cuidado é relativamente nova, tendo sido adotada especialmente nos debates que envolvem o envelhecimento populacional e a necessidade de provisionamento de cuidados para a população idosa. Ainda assim, as noções que o termo carrega historicamente se perpetuam no país, conforme afirmam Nadya Araújo Guimarães, Helena Hirata e Kurumi Sugita (2012, p. 82):

(...) se é certo que cuidado, ou atividade do cuidado, ou mesmo ocupações relacionadas ao cuidado, como substantivos, foram introduzidos mais recentemente na língua correspondente, as noções de 'cuidar' ou de 'tomar conta' têm vários significados, sendo expressões de uso cotidiano. (...) O 'cuidar da casa' (ou 'tomar conta da casa'), assim como o 'cuidar das crianças' (ou 'tomar conta das crianças') ou até mesmo o 'cuidar do marido', ou 'dos pais', têm sido tarefas exercidas por agentes subalternos e femininos, os quais (talvez por isso mesmo) no léxico brasileiro têm estado associados com a submissão, seja dos escravos (inicialmente), seja das mulheres, brancas ou negras (posteriormente).

Para esta pesquisa interessa mobilizar a categoria "cuidado" por ela, aparentemente, opor-se à categoria "trabalho" enquanto produtor de mercadorias, formando um par representativo da dicotomia público/privado, natureza/cultura, racional/emotivo, masculino/feminino. Importante elucidar que, ao tratar do cuidado, parte-se do pressuposto de que o sexo é uma construção social, do que decorre a recusa de qualquer explicação de cunho biológico ou essencialista para a diferenciação de práticas entre masculinas e femininas.

Desse modo, a partir de uma perspectiva materialista, entende-se que mulheres e homens não são duas coleções de indivíduos biologicamente diferentes, mas sim "dois grupos sociais envolvidos numa relação social específica: as relações sociais de sexo", as quais, como todas as relações sociais, "possuem uma base material, no caso o trabalho, e se exprimem por meio da divisão sexual do trabalho" (KERGOAT, 2009, p. 67). A divisão sexual do trabalho, por sua vez, caracteriza-se pela "designação prioritária dos homens à esfera produtiva e das mulheres à esfera reprodutiva e, simultaneamente, a 
apropriação pelos homens das funções de maior valor social adicionado" (HIRATA; KERGOAT, 2008b, p. 266).

Logo, o cuidado da casa e da família é predominantemente delineado como uma função feminina, pouco ou nada valorizada, a ser desempenhada por amor e vocação. Se houve uma visível evolução do trabalho assalariado feminino nas últimas décadas, demonstrada pelos dados anteriormente apresentados, e mesmo com desenvolvimento tecnológico que facilitou as tarefas domésticas, "a divisão sexual do trabalho doméstico e a atribuição deste último às mulheres, em realidade, continuou intacta" (HIRATA, 2002, p. 150), de modo que a tendência, na atualidade, é de "a maioria dos homens investir seu tempo prioritariamente no mercado de trabalho enquanto a maioria das mulheres se divide entre o trabalho remunerado e os cuidados da família" (SORJ; FONTES, 2012, p. 105).

A temática do trabalho das mulheres e o cuidado é alvo de pesquisas no campo do Direito, ainda que com alcance restrito, dentro da denominada Teoria Feminista do Direito do Trabalho, desenvolvida especialmente entre norte-americanas e britânicas ${ }^{4}$. Estes estudos dialogam com as críticas feministas ao salário-família feitas nos anos 1990 (FRASER, 1994; HORREL; HUMPHRIES, 1998) e avançam no sentido de revelar as estruturas jurídicas centradas no masculino e buscar uma legislação mais inclusiva, levando em conta experiências de grupos marginalizados (CRAIN, 1992; MORRIS; O’DONNEL, 1999), bem como a necessidade de inclusão do cuidado e do trabalho doméstico no escopo do Direito (FUDGE, 2014; CONAGHAN, 2014; WEST, 1999).

Entretanto, a transposição direta da visão dessas juristas feministas para o Direito brasileiro não é possível, afinal nossa realidade é indubitavelmente distinta, os pressupostos do Estado de bem-estar social, do qual essas teorias partem, nunca foram de fato implantados no Brasil - ou na América Latina (LAGARDE, 2003) - e as dinâmicas de trabalho, tal qual as particularidades na intersecção das relações de gênero, raça e classe na sociedade brasileira - no que se incluem, por exemplo, os desdobramentos do período colonial e da escravidão - conferem ao país características muito próprias.

Desse modo, a contribuição original da presente tese é dialogar com as pesquisas que já versaram sobre as barreiras para a igualdade de gênero no trabalho e constataram o cuidado como fonte central dessa exclusão e refletir sobre a maneira como os fundamentos do Direito do Trabalho corroboram com este quadro no Brasil. Desse modo,

\footnotetext{
${ }^{4}$ Interessante mencionar que em 2013, a Kent Law School, na Inglaterra, sediou o workshop "Gendering Labour Law", no qual foi formada a Gender Labour Law Research Network, com o objetivo de cultivar os estudos feministas e críticos em Direito do Trabalho (FUDGE; GRABHAM, 2014, p. 1).
} 
se as diversas correntes do pensamento feminista utilizaram variáveis sociais, econômicas e culturais para analisar a realidade do trabalho das mulheres no país, esta tese coloca o ordenamento jurídico nacional como mais um ator que tem seu papel nesse conjunto.

No meio jurídico nacional, os trabalhos debruçados sobre gênero e Direito do Trabalho avolumaram-se nos últimos anos, mas com enfoques diversos do aqui proposto ${ }^{5}$. A maioria dessas pesquisas voltam o olhar para aplicação das normas trabalhistas em análises que abordam o tratamento distinto conferido a homens e a mulheres na lei e no sistema judiciário (BARROS, 1995; NOBRE; RODRIGUEZ, 2012), a discriminação no trabalho (NOVAIS, 2004; MALLET, 2013) e a colocação das mulheres nos espaços profissionais, como sindicatos ou em cargos de destaque e chefia (THOME, 2012; BONELLI, 2013; BERTOLIN, 2017).

Entretanto, o Brasil carece de pesquisa que lance mão do cuidado para refletir sobre o próprio escopo do Direito do Trabalho, deixando visível que suas categorias básicas são marcadas pelo gênero, as quais, apesar de pretenderem-se universais, abordam o trabalho a partir de um padrão de indivíduo que não condiz com a realidade e que, centrando no recorte desta tese, é sexista. Assim, a formatação da maioria dos dispositivos legais pressupõe um homem trabalhador, formalmente empregado, que pode, por exemplo, ficar oito horas ininterruptamente no seu posto de trabalho, já que não precisa buscar os filhos na creche, ou que pode esperar um ano inteiro para gozar férias de 30 dias, já que não engravida ao longo de sua vida ativa.

A vinculação da proposta de pesquisa ao estudo do Direito é nítida, uma vez que se propõe a investigar a atual configuração do ordenamento jurídico brasileiro, em específico o modo como o cuidado é positivado ou excluído das normas trabalhistas, e sua influência para a desigualdade das mulheres no mundo do trabalho. Se, nas palavras de Tarso de Melo (2015, p. 770), a crítica jurídica tem como questão-chave "reconhecer o papel do Direito na dominação social" e ao mesmo tempo "reconhecer que se trata consequentemente de um campo importantíssimo para as lutas sociais", esta tese se adequa à disciplina.

\footnotetext{
${ }^{5}$ Esta constatação é fruto da somatória de três frentes. A primeira foi a busca detalhada na Biblioteca Digital de Teses e Dissertações (BDTD) do Instituto Brasileiro de Informação em Ciência e Tecnologia (IBICT) e na Biblioteca Digital da FAPESP, utilizando palavras-chave "direito do trabalho", "seguridade social" e "direitos sociais" associadas em pares com "gênero", "mulher", "feminismo" e "cuidado". A segunda frente foi a busca no catálogo geral da Biblioteca da Faculdade de Direito da Universidade de São Paulo (USP), utilizando as combinações "trabalho e gênero", "trabalho e mulher", "seguridade e gênero", "seguridade e Mulher" e a palavra-chave "cuidado". Por fim, leva-se em consideração as pesquisas realizadas para desenvolvimento desta tese e o conhecimento acumulado da professora e professores presentes na banca de exame de qualificação.
} 
Nesse sentido, o objetivo geral é revisitar, a partir da perspectiva de gênero, as bases teóricas e categorias fundamentais do Direito do Trabalho a fim de testar a hipótese principal de que o conceito de "trabalho" presente na legislação trabalhista é masculino e excludente, já que compreende apenas as atividades que podem ser enquadradas como exercidas na esfera pública ${ }^{6}$ ou realizadas em troca de pagamento, o que elimina, a priori, o cuidado exercido majoritariamente por mulheres, seja de forma exclusiva ou complementar ao trabalho remunerado, ampliando, desse modo, as barreiras no processo de promoção da igualdade de gênero.

Destarte, este estudo propõe-se a tecer crítica à noção de trabalho que alicerça o Direito do Trabalho brasileiro e, consequentemente, ao próprio escopo da disciplina, fazendo-se imprescindível enfatizar, desde esta introdução, que esse esforço vai no sentido de dar passos rumo ao fortalecimento e evolução do campo juslaboralista, que é alvo de constantes e duros ataques no Brasil e no mundo, sem, em momento nenhum, corroborar com qualquer argumento em prol da desregulamentação do trabalho.

A perspectiva de gênero e a utilização da categoria cuidado permitirão, assim, demonstrar a necessidade de que os fundamentos da Teoria do Direito do Trabalho passem a englobar homens e mulheres de modo isonômico, contemplando não somente demandas da produção, mas também demandas da reprodução da vida. Em termos sociais, abrirá caminhos de pesquisa sobre a possibilidade de mudança na forma como o Direito trata tempos e modos de mensurar trabalho, a fim de eliminar obstáculos à igualdade de gênero imbricados na legislação.

A linha de raciocínio que permitirá a realização do percurso aqui proposto passará por quatro capítulos. O Capítulo 1 aborda a tríade trabalho, gênero e cuidado com o intuito de formar o arcabouço teórico feminista da tese, apresentando vertentes interdisciplinares de análise do cuidado, subdividido em quatro abordagens: i) ética do cuidado; ii) cuidado como trabalho; iii) Economia Feminista; e iv) crise do cuidado. As três primeiras voltam-se para a reconstrução do caminho teórico de cada uma dessas vertentes, enquanto a última contextualiza a problemática do cuidado na conjuntura global das primeiras décadas do século XXI.

\footnotetext{
${ }^{6}$ Relevante esclarecer que ao falar de esfera pública, em contraposição ao espaço privado, toma-se como referência a divisão entre mercado e casa/família, sendo o primeiro considerado público e o segundo privado; perspectiva diversa é a que toma mercado e Estado como referência, em que aquele é relacionado ao privado e este ao público. Ou seja, o que as feministas chamam de trabalho no espaço público é o trabalho que não é doméstico e é normalmente remunerado, independente se a prestação de serviço se dá no setor privado ou no setor público
} 
Imbuído de tais bases teóricas, o Capítulo 2 busca demonstrar a formação sexista do Direito do Trabalho, tarefa que se inicia com a apresentação da Teoria Feminista do Direito do Trabalho, linha de pesquisa desenvolvida por pesquisadoras do campo juslaboralista na América do Norte e Grã-Bretanha. A partir das reflexões das estudiosas desse campo, o capítulo expõe as críticas acerca da concepção jurídica de "trabalho", do modelo de trabalhador universal adotado pela lei trabalhista, do paradigma do tempo cronológico como forma de mensurar o trabalho e, por fim, da carga de gênero contida na noção de salário.

O Capítulo 3 coloca em questão a forma como o cuidado é tratado pelo Direito do Trabalho no Brasil, começando com considerações sobre o trabalho de cuidado no país, para que não se percam de vista as peculiaridades do modelo brasileiro. $\mathrm{Na}$ sequência, examina o processo de elaboração de normas trabalhistas relativas às responsabilidades familiares, especificamente intervalo para amamentação, folgas para cuidar da saúde de pessoas da família, licença-maternidade, licença-paternidade e direito à creche. $\mathrm{O}$ mesmo é feito com as normas relativas ao trabalho doméstico remunerado, descrição que compartilha relatos históricos sobre a construção dos direitos trabalhistas dessa categoria, culminando na descrição do estado da arte da regulação da profissão de cuidadora. Para encerrar, são abordadas a comoditização do cuidado e a reforma trabalhista, com vistas a atualizar o debate de acordo com as recentes mudanças na lei.

Por fim, o Capítulo 4 agrega à análise anteriormente realizada a perspectiva das organizações de trabalhadoras domésticas e movimentos feministas sobre as normas trabalhistas relativas ao cuidado, buscando entender se o Direito do Trabalho é por elas considerado um meio de resposta para as demandas por igualdade de gênero. Diante disso, são esboçados caminhos para a reformulação do escopo da disciplina, centrados nos debates sobre dependência e cidadania, que também abrem espaço para o desenvolvimento das conclusões da tese.

Antes de tudo isso, porém, apresento no próximo item as notas metodológicas relativas à presente investigação, que demandou pesquisa bibliográfica, apreciação da legislação nacional em vigor, mapeamento e análise do processo legislativo por meio de pesquisa documental, bem como e realização de entrevistas. 


\section{METODOLOGIA}

O processo de escrita desta tese contou com diferentes materiais e métodos, que se consubstanciaram em etapas alternadas de pesquisa bibliográfica, apreciação da legislação nacional em vigor, mapeamento e análise do processo legislativo e entrevistas. Antes de pormenorizar a execução dessas etapas, porém, algumas notas a respeito das escolhas feitas ao longo desse percurso precisam ser feitas. Começo pela minha pretensão, que não foi tratar de conceitos e posicionamentos relacionados ao Direito do Trabalho em termos puramente teóricos e genéricos, mas refletir de maneira crítica a respeito do que a teoria jurídico-trabalhista não faz ou deixa à sua margem, apoiando-me nas bases e nas ausências que formam o ordenamento jurídico nacional, assim como na materialidade das vivências das mulheres que foram minhas interlocutoras ao longo de todo o curso da pesquisa.

Nesse sentido, respaldo-me em Sandra Harding (2004) e na Feminist Standpoint Theory ${ }^{7}$, que se atentam às relações entre a produção do conhecimento e as práticas de poder, reconhecendo que o fazer científico está sempre, em diversos aspectos, situado socialmente. Consequentemente, o conhecimento produzido de forma situada não é neutro, imparcial ou desinteressado, do que decorre a busca por dar espaço a grupos oprimidos valorizando suas experiências, fazendo também contraponto à ideia de que as preocupações feministas restringem-se a questões "das mulheres" em âmbito social ou político, devendo ser levados em consideração padrões do que conta como conhecimento, objetividade, ciência e método científico (HARDING, 2004, p. 2). ${ }^{8}$

Aplicada à presente tese, esse embasamento teórico explicita que o intuito aqui não é de apresentar um trabalho acabado e imutável, mas de oferecer uma compreensão mais abrangente do mundo do trabalho, fazendo o esforço de incluir múltiplos pontos de

\footnotetext{
${ }^{7}$ Para um panorama introdutório sobre epistemologia feminista e Feminist Standpoint Theory, cf.: ANDERSON, 2017.

${ }^{8}$ Conforme Harding (2004, p. 3) ressalta, a Feminist Standpoint Theory tem inspiração no projeto marxiano, que se apresentou como alternativa à ciência burguesa, ainda que não tenha avançado a ponto de considerar as mulheres como grupo social dentro do proletariado. Ao fazer "do proletariado, guiado pela teoria e pela luta de classes, o detentor do conhecimento por excelência, o único grupo capaz de usar a observação e a razão para apreender a verdadeira forma das relações sociais, inclusive as relações com a natureza", a epistemologia marxista rompeu pela primeira vez com a tradição iluminista que considerava que apenas homens que pertenciam à classe, à raça e à cultura "corretas" poderiam ser mentes humanas reflexivas e universalizantes, ou seja, sujeitos - não só objetos - do pensamento científico (HARDING, 1993, p. 17).
} 
vista, que fornecem percepções mais ricas sobre a operação e os efeitos das normas trabalhistas sobre diferentes grupos (CONAGHAN, 1999, p. 25).

Dessa escolha metodológica decorre, ainda, a opção pelo uso da primeira pessoa do singular, com o intuito de evitar o uso do sujeito indeterminado, com certa pretensão de fala "onisciente" ou imparcial, ou do plural majestático, eufemismo para a existência de um sujeito-enunciador". Adoto a lição de Maria José R. Faria Coracini (1991, p. 110), de que "apesar do desejo de imparcialidade e neutralidade (isenção de toda subjetividade), o discurso científico revela sua subjetividade no uso dos tempos verbais, no uso das formas modais, no uso das construções ativas e passivas", de modo que o uso do "eu" será também instrumento que permitirá uma narrativa mais clara do percurso desta pesquisa ${ }^{10}$.

Ademais, sempre que possível, procurei utilizar o feminino genérico para designar uma população predominantemente feminina. Por isso, ao falar de "trabalhadoras domésticas" ou "cuidadoras", incluo também os homens que integram a categoria, mas que estão em número bastante reduzido, uma vez que as mulheres correspondem a $93 \%$ do total de trabalhadores e trabalhadoras domésticas no Brasil (IPEA, 2011, p. 4).

Retomando as etapas executadas, no âmbito da pesquisa bibliográfica houve a seleção de obras que deram embasamento teórico para a análise a ser desenvolvida, abarcando: doutrinadores do Direito do Trabalho; autores das ciências sociais que estudam o conceito de trabalho; teóricas feministas do Direito e teóricas feministas do Direito do Trabalho; autoras da área da sociologia que estudam trabalho, gênero e cuidado; teóricas feministas que trabalham o cuidado; autoras da economia feminista.

Quanto à apreciação da legislação nacional em vigor, foi elaborado um panorama da inserção do cuidado e dos direitos a ele associados; os temas foram

\footnotetext{
${ }^{9}$ Donna Haraway (1995, p. 19) reforça essa escolha, tendo na base de sua teoria sobre os saberes localizados a crítica ao sujeito do conhecimento que reivindica ser o agente que realiza o "truque de Deus", ou seja, que é capaz de "ver tudo de lugar nenhum". "Acima de tudo, o conhecimento racional não tem a pretensão do descompromisso: de pertencer a todos os lugares e, portanto, a nenhum, de estar livre da interpretação, da representação, de ser inteiramente autocontido ou inteiramente formalizável. $\mathrm{O}$ conhecimento racional é um processo de interpretação crítica contínuo entre "campos" de intérpretes e decodificadores. O conhecimento racional é uma conversa sensível ao poder" (HARAWAY, 1995, p. 33).

${ }^{10}$ De maneira alguma isso implicará menor seriedade ou comprometimento desta pesquisadora. A esse respeito, do ponto de vista da Linguística: “(...) o conceito de objetividade/subjetividade é relativo, portanto, à comunidade interpretativa: para uns, não se rompe a objetividade usando a primeira pessoa (antes, ela é garantida pela função dêitica), para outros, a única estratégia aceitável, em termos de tempo e pessoa, é o uso de formas passivas e de sujeito indeterminado ou na pessoa" (CORACINI, 1991, p. 111).
} 
divididos em responsabilidades familiares, emprego doméstico e regulamentação de profissões do cuidado, com um recorte que se inicia na Consolidação das Leis do Trabalho, passa pela Lei 5.872/1972, Constituição de 1988, Emenda Constitucional 72/2013 e Lei Complementar 150/2015. Com o escopo teórico da etapa anterior, foi possível fazer transparecer o viés de gênero nas normas positivadas, bem como nos princípios e fundamentos que regem o Direito do Trabalho. Ademais, durante a execução da pesquisa, houve a necessidade de incluir algumas considerações sobre a Lei $13.467 / 2017$, por ela ter pautado o debate nacional nos últimos dois anos e por refletir alguns dos pontos conjunturais que estavam no horizonte de preocupações desta tese.

O mapeamento e análise do processo legislativo fundou-se em pesquisa documental nos acervos eletrônicos do Congresso Nacional e do Diário Oficial envolvendo a tramitação, a aprovação e o conteúdo de normas trabalhistas que versam sobre cuidado e responsabilidades familiares, a fim de compreender como e em quais circunstâncias temas como direito à creche, licença à gestante e licença-paternidade foram inseridos no ordenamento jurídico nacional e sob qual perspectiva. Foram três focos de análise: i) gênese da Consolidação das Leis do Trabalho $(\mathrm{CLT})^{11}$, que representa o momento no qual organizaram-se os direitos trabalhistas no Brasil e, logo, o trabalho passa a ser especificado na legislação; ii) processo de elaboração da Constituição de 1988, tendo em perspectiva a mobilização social, audiências públicas e encaminhamentos da Assembleia Nacional Constituinte de 1987 relativos à temática ${ }^{12}$; iii) atividade legislativa recente relativa ao trabalho doméstico e de cuidado, incluindo a Emenda Constitucional 72/2013 sobre igualdade do emprego doméstico e a Lei Complementar 150/2015.

Com relação à realização de entrevistas, primeiro é preciso frisar que, no Brasil, a luta pela socialização do trabalho doméstico é pauta histórica do movimento feminista e das mulheres organizadas em sindicatos, conscientes das barreiras que os encargos reprodutivos impõem a elas na sociedade, com registros de mobilizações relevantes em torno do tema desde o final dos anos 1970 (TELES, 1999, p. 103). Indispensável mencionar o papel central dos movimentos de mulheres durante a Assembleia Constituinte de 1987, decisivo para a inserção na Constituição de 1988 de direitos como

\footnotetext{
${ }^{11}$ Decreto Lei n. 5.452, de $1^{\circ}$ de maio de 1943, doravante chamado apenas CLT.

${ }^{12}$ No caso da Assembleia Constituinte de 1987, Mauro Márcio Oliveira (1993, p. 27) descreve a existência de três acervos distintos com registros de suas atividades e resultados: eletrônico, bibliográfico e arquivístico. Realizou-se a análise dos documentos existentes no acervo eletrônico e bibliográfico, incluindo bases-fonte, títulos publicados sobre a ANC e os Boletim e Jornal da Constituinte, sem a necessidade de recorrer aos demais para elucidar questões relativas a esta tese.
} 
licença-maternidade, licença-paternidade e assistência gratuita para crianças em creches e escolas infantis (TELES, 1999, p. 144).

Passadas algumas décadas, os movimentos de mulheres pluralizaram suas pautas, passando a focar especialmente demandas identitárias (BARBOSA, 2013, p. 28), porém continuaram a mobilizar grande parte de seus esforços na luta por efetivação e ampliação de direitos - vide, por exemplo, a conquista feminista que foi a Lei Maria da Penha para o combate da violência contra as mulheres (GROSSI; SARDENBERG, 2015, p. 497), ou a persistente reivindicação por direitos sexuais e reprodutivos. Nesse contexto, porém, não fica clara a compreensão que estes movimentos têm do direito, esclarecimento que tem o potencial de permitir aos juristas compreenderem as potencialidades e limitações da disciplina como instrumento para a igualdade de gênero.

Nesse caminho, documentos legislativos, a letra da lei e o debate teórico podem revelar parte dos intuitos e das relações de poder que interferem na elaboração do Direito e que dele são derivadas, mas não permitem captar como a sociedade enxerga e demanda do ordenamento jurídico. Assim, na busca por colocar em diálogo a pesquisa bibliográfica e documental com a prática social, foram realizadas entrevistas semiestruturadas (LETOURNEAU, 2009, p. 173) com integrantes de movimentos e organizações de mulheres e sindicais, com objetivo de verificar como o trabalho e o cuidado têm sido articulados por tais sujeitos em suas reivindicações.

Com efeito, foram selecionados grupos com inserção social relevante e demandas relativas à temática do cuidado e de trabalho das mulheres, com a ciência de que, por ser um recorte, seu alcance não consegue abranger todos os atores que possuem tais características. Os grupos selecionados foram: Federação Nacional das Trabalhadoras Domésticas - FENATRAD, Sindicato das/os Trabalhadoras/es Domésticas/os de Campinas e Região, Sindicato dos Trabalhadores Domésticos do Município de São Paulo - STDMSP, Federação Nacional dos Enfermeiros - FNE, Associação dos Cuidadores de Idosos da Região Metropolitana de São Paulo - ACIRMESP, Marcha das Margaridas, SOS Corpo - Instituto Feminista para Democracia e Sempreviva Organização Feminista SOF.

Justifica-se a seleção das organizações profissionais de trabalhadoras domésticas e de cuidado, em primeiro momento, pelo viés claramente sexista de sua composição, uma vez que $92 \%$ da força de trabalho no emprego doméstico é feminina (BRASIL, 2015, 
p. 17). Em termos particulares, a Federação Nacional das Trabalhadoras Domésticas, formada por 26 sindicatos representantes da categoria de 15 Estados brasileiros (FENATRAD, 2016), foi selecionada por sua marcante atuação na aprovação da Emenda Constitucional 72/2013, que buscou equiparar os direitos trabalhistas relativos ao emprego doméstico aos previstos para demais trabalhadores (BRASIL, 2011), sendo seu principal mote de ação política a valorização do trabalho doméstico. Da FENATRAD foram entrevistadas Creuza Maria Oliveira, secretária geral, e Luiza Batista Pereira, presidenta da Federação.

Quanto ao Sindicato das Trabalhadoras Domésticas de Campinas e Região, a escolha deve-se ao fato de ser historicamente um dos mais importantes do país, pois deriva da Associação de Empregadas Domésticas da cidade, fundada em 1961 por Laudelina de Campos Melo, figura representativa na reivindicação por direitos iguais para mulheres negras e trabalhadoras. Até os dias de hoje, o sindicato de Campinas é um dos mais atuantes no Brasil, tendo sido berço da estruturação do Conselho Nacional de Trabalhadoras Domésticas e da própria FENATRAD. Foram entrevistadas Eliete Ferreira da Silva, presidenta do sindicato, e Maria Regina Teodoro, integrante do sindicato desde 1995, tendo sido uma das representantes do Brasil na OIT nos debates sobre a Convenção $189 .{ }^{13}$

Já o Sindicato de Trabalhadoras Domésticas do Município de São Paulo (STDMSP) é um dos maiores do país em termos de estrutura e de fluxo de atendimento, reflexo de estar localizado na mais populosa cidade brasileira (AGÊNCIA IBGE, 2017). Com uma equipe jurídica bem estruturada, além da rotina de homologações de rescisões contratuais e atendimento para esclarecimento de dúvidas trabalhistas da categoria, o sindicato anualmente firma Convenção Coletiva de Trabalho com o Sindicato dos Empregadores Domésticos do Estado de São Paulo (SEDESP). Foi entrevistada Silvia Maria da Silva Santos, presidenta do sindicato.

A seleção da Federação Nacional dos Enfermeiros, formada por sindicatos de enfermeiros de 17 Estados brasileiros, justifica-se por sua defesa de pautas relativas ao trabalho de cuidado vinculado a enfermeiras, técnicas e auxiliares de enfermagem junto ao poder legislativo, inclusive em audiências públicas (BRASIL, 2015b). Dentre suas reivindicações, destaca-se a regulamentação da jornada de trabalho da enfermagem em 30

\footnotetext{
${ }^{13}$ Em 27 de abril de 2018, Eliete e Regina foram laureadas com a Medalha Laudelina de Campos Melo, oferecida pela Câmara Municipal de Campinas, em reconhecimento aos serviços prestados em favor dos direitos das mulheres e das trabalhadoras domésticas.
} 
horas, fundamentada na melhoria da qualidade da assistência prestada a pacientes, pois "as atividades desenvolvidas possuem características próprias, como o cuidar com qualidade profissional e responsabilidade, ambas imprescindíveis para salvar vidas" (FNE, 2014). Foi entrevistada Solange Aparecida Caetano, presidenta da Federação.

Em contraponto, o contato com Associação de Cuidadores de Idosos da Região Metropolitana de São Paulo (ACIRMESP) veio de sugestão da supervisora de pesquisa no exterior, Profa. Helena Hirata. O principal mote da associação é a regulamentação de profissões que envolvem o cuidado, como de cuidador ou gerontólogo, motivo pelo qual sua atuação é focada nos debates legislativos e no apoio de projetos de lei com esse foco, defendendo sua distinção (GIORGE, 2017). Da associação foi entrevistada sua presidenta, Lidia Nadir Giorge.

Dentre os movimentos e organizações de mulheres, a eleição da Marcha das Margaridas deve-se à sua construção como ação estratégica de trabalhadoras do campo e da floresta, coordenada pela Confederação de Trabalhadores Rurais - CONTAG, que mobiliza mulheres desde os anos 2000. A Marcha das Margaridas tem histórico de intenso diálogo com o Governo Federal e o Congresso Nacional, seja por meio da entrega de documentos com reivindicações (BRASIL, 2015a), seja por meio da participação em audiências públicas (BRASIL, 2016). O movimento reivindica autonomia econômica, trabalho e renda para as mulheres, no que se inserem demandas por "infraestrutura que contribua para a redução do trabalho das mulheres na esfera produtiva e reprodução", como "creches, escolas infantis, restaurantes e lavanderias comunitárias", visando a "socialização dos trabalhos domésticos" (CONTAG, 2015, p. 43). Foi entrevistada Alessandra da Costa Lunas, secretária das mulheres da CONTAG e organizadora da Marcha das Margaridas de 2015.

Quanto ao SOS Corpo - Instituto Feminista para a Democracia, sua seleção explica-se por ser uma organização da sociedade civil fundada em 1981, com sede em Recife, tendo reconhecida atuação em pesquisa e educação em áreas como direitos sexuais e reprodutivos e autonomia econômica das mulheres (SOS CORPO, 2018). De particular interesse para o presente estudo, o instituto, desde sua fundação, realiza trabalho junto a organizações de trabalhadoras domésticas, em especial na formação de integrantes para defesa de seus direitos (ÁVILA, 2017). A integrante do SOS Corpo entrevistada foi Maria Betânia Ávila, pesquisadora feminista reconhecida nacionalmente e coordenadora do instituto. 
Por fim, a Sempreviva Organização Feminista, organização não governamental que desde os anos 1980 atua na assessoria de movimentos de mulheres, organizações mistas e órgãos do governo, foi selecionada por ter uma abordagem que reflete sobre as imbricações entre relações econômicas e a cultura patriarcal, incluindo a economia feminista e o cuidado entre suas principais pautas (SOF, 2016). A SOF possui relevantes publicações sobre a temática, dentre as quais os livros "Trabalho doméstico e de cuidados: por outro paradigma de sustentabilidade da vida humana", de 2008, e "Feminismo, economia e política", de 2014. Entrevistei Nalu Faria, integrante da SOF desde 1986 e uma das coordenadoras das publicações da organização (TORNQUIST; FLEISCHER, 2012, p. 291).

Para essa etapa da investigação, que se propunha a verificar se a forma como o cuidado é tratado pelo Direito do Trabalho favorece a inclusão ou exclusão das mulheres do emprego e responder se a assimilação de profissões relacionadas ao cuidado pelo Direito eliminaria sua marcação de gênero e as valorizaria, surgiu ainda a necessidade de aprofundamento da pesquisa de campo, especialmente no que diz respeito à organização das trabalhadoras domésticas.

Por conta disso, embasada na formulação de Jeanne Favret-Saada (2005) sobre "ser afetada" - a respeito dos limites do fazer etnográfico, dos impactos da experiência da pessoa pesquisadora e do descompasso do tempo da análise teórica com o tempo da vivência -, participei de dois eventos que congregavam organizações de domésticas de todo o Brasil, que foram o Seminário "Lutas e Desafios das trabalhadoras Domésticas no Mundo do Trabalho", organizado pela Central Única dos Trabalhadores - CUT ${ }^{14}$, e a Assembleia Nacional da FENATRAD ${ }^{15}$, bem como passei a frequentar o Sindicato de Trabalhadoras Domésticas de Campinas e Região, auxiliando no trabalho de mobilização e apoio a outros sindicatos de domésticas do Estado. O método adotado foi a observação participante, apropriando-me dos ensinamentos de Ana Lúcia Pastore Schritzmeyer (2007, p. 119) de que a experiência etnográfica não pode ser uma busca por encaixar-se

\footnotetext{
${ }^{14}$ Realizado em São Paulo, no dia 4 de setembro de 2017, o seminário debateu as barreiras para a sindicalização da categoria, com participação de trabalhadoras domésticas de diversos Estados do Brasil, dirigentes sindicais da CUT e acadêmicas.

${ }^{15}$ Realizado em Brasília, entre os dias 14 e 17 de dezembro de 2017, teve a participação de sindicatos e associações de trabalhadoras domésticas de todas as regiões do país que compõem a FENATRAD. Nesta Assembleia, houve a oficialização da Federação enquanto entidade sindical, permitindo a mim melhor conhecer essas interlocutoras e compreender sua relação com as demandas legais.
} 
em modelos teóricos, mas sim de permitir vivências, percepções e afetos que compõem uma dentre várias narrativas possíveis.

Depois de realizadas e transcritas as entrevistas e as observações participantes, sua análise preliminar (MINAYO; DESLANDES; GOMES, 2009) foi combinada à pesquisa bibliográfica que formou o escopo teórico deste estudo. Na perspectiva jurídica, a fala das interlocutoras foi articulada à pesquisa documental, de modo a verificar quais normas trabalhistas referentes ao cuidado e às responsabilidades familiares foram mencionadas nas entrevistas, quais ficaram omissas e qual a percepção das entrevistadas sobre a efetividade do Direito e seu papel no combate travado por elas contra a desigualdades de gênero no trabalho.

Importante destacar que fatores conjunturais tiveram influência no resultado das entrevistas, de maneira que é possível dividi-las temporalmente no seguinte sentido: Creuza, Eliete, Lídia, Silvia, Nalu e Solange foram entrevistadas entre novembro de 2016 e janeiro de 2017, quando as reformas trabalhista e previdenciária impostas pelo governo de Michel Temer ainda não tinham ganhado força no debate político nacional; Alessandra e Maria Betânia foram entrevistadas entre março e abril de 2017, quando essas reformas já tramitavam no Congresso e estavam na iminência de serem aprovadas; Regina e Luiza foram entrevistadas depois da promulgação da Lei 13.467/2017. Isso teve interferência na perspectiva das entrevistadas sobre o Direito do Trabalho, que passou a ser defensiva, no sentido de garantir a continuidade de direitos historicamente conquistados, conforme será registrado ao longo do texto.

Além disso, para aprofundar o desenvolvimento teórico da tese, também foram realizadas entrevistas pessoais com duas professoras cuja área de pesquisa e produção foram pilares teóricos do presente trabalho ${ }^{16}$. A primeira delas foi Judy Fudge, professora da Faculdade de Direito da Universidade de Kent, fundadora da Rede de Pesquisa em Gênero e Direito do Trabalho (Gender Labour Law Research Network) e um dos maiores expoentes da crítica feminista voltada à disciplina, que neste trabalho chamo de Teoria Feminista do Direito do Trabalho (FUDGE; GRABHAM, 2014, p. 1).

Também tive a oportunidade de entrevistar Cristina Carrasco, da Universidade de Barcelona, pesquisadora mundialmente renomada na área da Economia Feminista.

\footnotetext{
${ }^{16}$ Estas entrevistas foram realizadas durante meu estágio de pesquisa doutoral no exterior, apoiado pela FAPESP (BEPE/Doutorado - Processo n ${ }^{\circ}$. 2017/00743-4), sob a supervisão da professora Helena Hirata no Centre de Recherches Sociologiques et Politiques de Paris, equipe Genre, Travail, Mobilités.
} 
Chilena exilada para a Espanha, além de ter sido a primeira a defender uma tese de doutorado em Economia sobre trabalho doméstico no país, Carrasco foi pioneira em fundar a disciplina "Mulheres e Economia", que posteriormente se desenvolveu até a criação do Instituto de Estudos de Mulheres e Gênero na mesma universidade (CARRASCO, 2017).

Por fim, no âmbito da análise legislativa, foram realizadas entrevistas com vistas a mapear os bastidores dos processos legislativos concernentes à ampliação de direitos trabalhistas para as trabalhadoras domésticas, a fim de melhor registrar as dinâmicas e os atores relevantes nos debates travados no Congresso Nacional. Nesse intuito, entrevistei Glaucia Fraccaro, professora da PUC-Campinas e diretora na Coordenadoria de Autonomia Econômica da Secretaria de Políticas para as Mulheres da Presidência da República no período de 2011 a 2012, tendo acompanhado parte da articulação política para aprovação da Emenda Constitucional 72/2013.

Com o mesmo objetivo, entrevistei a Deputada Federal Benedita da Silva, personagem central do Poder Legislativo no que se refere à temática dos direitos das trabalhadoras domésticas. Mencionada nas entrevistas com integrantes do movimento sindical como uma grande parceira na defesa e ampliação de direitos para a categoria, Benedita da Silva foi Deputada constituinte, Deputada Federal, a primeira Senadora negra e Ministra da Assistência Social no governo Lula (SILVA, s./d.). Em 2010, foi eleita novamente Deputada Federal, tendo pautado desde então os debates parlamentares em torno da Emenda Constitucional 72/2013 e da Lei Complementar 150/2015, além de ser relatora de projetos de lei que regulamentam profissões relacionadas ao cuidado.

A última entrevista realizada foi com Maria do Carmo Godinho Delgado, doravante Tatau Godinho, que além de doutora em Ciências Sociais e militante feminista, assumiu em 2005 a coordenação de ações temáticas da Secretaria de Política para as Mulheres da Presidência da República, tornando-se posteriormente secretária de políticas do trabalho e autonomia econômica da SPM, de 2011 a 2016 (COSTA, 2015, p. 13). Nesse período, participou direta e ativamente dos debates sobre ampliação de direitos trabalhistas para as trabalhadoras domésticas no período, incluindo a participação do Brasil nas etapas que levaram à aprovação da Convenção 189 pela OIT, o trâmite legislativo da Emenda Constitucional 72/2013 e da Lei Complementar 150/2015. 
Friso que a realização das entrevistas foi autorizada pela Comissão de Ética em Pesquisa da Faculdade de Direito da Universidade de São Paulo, em despacho de seu presidente, Prof. José Eduardo Campos de Oliveira Faria, de 23 de janeiro de 2017. As cópias dos termos de consentimento livre e esclarecido entregues às entrevistadas e assinados por elas, por mim e pelo orientador desta tese podem ser encontradas no item Anexos. 


\section{CAPÍTULO 1}

\section{TRABALHO, GÊNERO E CUIDADO: ARCABOUÇO INTERDISCIPLINAR PARA ANÁLISE}

Em busca por demonstrar a carga social e histórica presente nas noções que servirão de base para a interpelação do Direito do Trabalho aqui proposta, este capítulo tem como proposta refletir sobre a tríade trabalho, gênero e cuidado, levando em conta as relações de homens e mulheres no mundo do trabalho. Usado para descrever "processos, relações e sentimentos entre pessoas que cuidam umas das outras, como também de seres vivos e até mesmo de objetos, cobrindo várias dimensões da vida social" (HIRATA; DEBERT, 2016, p. 7), o cuidado (care) é considerado pelos estudos feministas como variável central para a opressão de gênero a partir da percepção de que as atividades a ele relacionadas são, predominantemente, desempenhadas por mulheres ou transferidas para mulheres de classes mais baixas, além de serem desvalorizadas pelo sistema econômico.

A fim de melhor compreender os debates em torno do cuidado, a divisão didática feita por Francesca Scrinzi (2016, p. 106) é um bom ponto de partida, na qual ela apresenta três formas de abordar o conceito a partir de enfoques das ciências sociais: o cuidado como ética (le care en tant qu'éthique); cuidado como trabalho (le care en tant que travail); e crise do cuidado (crise du care). Complementarmente, para formar o arcabouço teórico aqui pretendido, houve ainda a necessidade de incluir uma quarta vertente, a Economia Feminista, uma vez que a centralidade do discurso econômico sobre os debates em torno da regulação do trabalho exigem atenção - e crítica.

Dessa forma, ética do cuidado, trabalho como cuidado, o pensamento econômicofeminista sobre o cuidado e um panorama sucinto sobre a crise do cuidado pela qual o mundo passa na atualidade - com a devida distinção entre as realidades experimentadas por países do centro e da periferia - serão o foco de atenção dos próximos itens. Essas quatro abordagens estão densamente imbricadas, ao mesmo tempo em que possuem referências e desdobramentos próprios que merecem detalhamento, de modo a formar parte do embasamento teórico desta tese e permitir a análise do Direito do Trabalho a partir da perspectiva de gênero, tendo como baliza o cuidado em toda sua complexidade. 


\section{1 ÉTICA DO CUIDADO}

O campo de reflexão da ética do cuidado foi inaugurado pelo trabalho de Carol Gilligan, intitulado Uma voz diferente (In a different voice, 2003) e publicado nos Estados Unidos em 1982, que resultou de uma pesquisa sobre as experiência de homens e mulheres diante de conflitos morais. Partindo da crítica de que as teorias do desenvolvimento moral ouviam apenas as vozes dos homens, a autora afirma que o caminho moral das mulheres constatado empiricamente, a "voz diferente", seria a expressão do que ela chamou de ética do cuidado, diferenciando-a da ética da justiça, que na teoria de Lawrence Kohlberg era equiparada à maturidade moral (GILLIGAN, 2003, p. 27, 173). Segundo a autora,

Enquanto uma ética da justiça procede da premissa da igualdade - de que todos devem ser tratados da mesma forma -, uma ética de cuidado baseia-se na premissa da não-violência - de que ninguém deve ser ferido. $\mathrm{Na}$ representação da maturidade, ambas as perspectivas convergem na percepção de que, assim como a desigualdade afeta negativamente ambas as partes em um relacionamento desigual, a violência também é destrutiva para todos os envolvidos. Esse diálogo entre justiça e cuidado não apenas fornece uma melhor compreensão das relações entre os sexos, mas também dá origem a um retrato mais abrangente do trabalho adulto e das relações familiares (GILLIGAN, 2003, p. 174 , tradução nossa). ${ }^{17}$

Em outras palavras, a ética do cuidado "não se baseia em princípios universais, mas parte das experiências ligadas ao cotidiano e problemas morais de pessoas reais em suas vidas comuns" (LAUGIER; PAPERMAN, 2008, p. V, tradução nossa). Tratar-se-ia de uma "forma diferente de resolver dilemas morais, baseada não em critérios da lei e da imparcialidade, como acontece na ética da justiça, mas em critérios relacionais e contextuais" (MOLINIER, 2012, p. 29). No entanto, ao vincular essa percepção da moralidade à experiência das mulheres, Gilligan não se preocupou com o motivo pelo qual haveria a correlação de gênero por ela observada (TRONTO, 1993, p. 96), razão

\footnotetext{
${ }^{17}$ Excerto original: "While an ethic of justice proceeds from the premise of equality-that everyone should be treated the same-an ethic of care rests on the premise of nonviolence-that no one should be hurt. In the representation of maturity, both perspectives converge in the realization that just as inequality adversely affects both par- ties in an unequal relationship, so too violence is destructive for everyone involved. This dialogue between fairness and care not only provides a better understanding of relations between the sexes but also gives rise to a more comprehensive portrayal of adult work and family relationships".
} 
pela qual sua obra precursora serviu de referência para a área, mas também foi alvo de muitas críticas que a consideraram essencialista (SCRINZI, 2016, p. 108). ${ }^{18}$

Patricia Paperman e Sandra Laugier (2011, p. 10) explicam que, especialmente na França, a crítica à Gilligan ia no sentido de que a ética do cuidado por ela descrita não poderia ser feminista, por fazer uma distinção homem/mulher de conteúdo moral ao afirmar que as mulheres representam a atenção com o outro, enquanto os homens encarnariam a autonomia e a imparcialidade. Disso derivaria a acusação de que a ética do cuidado, por mostrar a importância social, moral e política das qualidades de atenção e das atividades de cuidado com outras pessoas, seria um reforço dos estereótipos de gênero $^{19}$ (PAPERMAN; LAUGIER, 2011, p. 10).

Para as autoras, porém, esse tipo de interpretação confirma a dificuldade de compreender e aceitar as implicações da ética do cuidado, a qual toca um ponto nevrálgico das relações sociais de sexo ao propor que a desvalorização de certas características associadas às mulheres seja reconsiderada (PAPERMAN; LAUGIER, 2011, p. 11). Destarte, também asseveram que "a ética do cuidado se baseia em uma análise das condições históricas que promoveram uma divisão do trabalho moral em virtude da qual as atividades de cuidado têm sido social e moralmente depreciadas". (PAPERMAN; LAUGIER, 2011, p. 12). Sendo assim,

[a] força da ética do cuidado foi, logo que introduzida por Gilligan, de dar lugar aos sentimentos e à preocupação com os outros, na política e na justiça: mas por falta de compreensão da dimensão política dos sentimentos e da experiência concreta do trabalho de cuidado, o chamado a uma "sociedade de cuidados" é tão vão quanto conformista. Ao fazer a pergunta "quem faz o que e como?" evitaríamos alguns malentendidos sobre a ideia de "cuidado mútuo" (PAPERMAN; LAUGIER, 2011 , p. 15, tradução nossa). ${ }^{20}$

\footnotetext{
${ }^{18}$ Outras críticas a Gilligan também foram elaboradas, como a de Patricia Hill Collins (2002, p. 6), que denuncia o fato de sua abordagem sobre o desenvolvimento moral estar assentada em mulheres brancas de classe-média.

${ }^{19}$ Lembrando que a categoria "gênero" foi adotada por parte do feminismo para se opor aos estereótipos do que seria a "natureza feminina" baseados no sexo dito biológico, explicitando a historicidade das diferenciações entre homens e mulheres. Para aprofundamento, cf.: SCOTT, 1995 e LOURO, 1996.

${ }^{20}$ Excerto original: "La force de l'éthique du care était, dès son introduction par Gilligan, de faire place aux sentiments, et au souci des autres, dans la politique et la justice: mais faute d'une compréhension de la dimension politique des sentiments, et de l'expérience concrète du travail de care, l'appel à une "société $d u$ soin » est aussi vain que conformiste. En posant la question " qui fait quoi e comment? ", on éviterait quelques malentendus sur l'idée d'un « soin mutuel »".
} 
Dando sequência ao raciocínio, Paperman e Laugier (2011, p. 17) afirmam que a potência da análise de Gilligan reside em evidenciar o caráter de gênero nos valores sociais e julgamentos morais e intelectuais, o que ela conseguiu ao mostrar empiricamente que os critérios que definem o que é bom ou mau, valioso ou desprezível são apresentados como universais, mas na verdade são critérios masculinos de uma sociedade patriarcal, ou seja, são "valores derivados da dominação masculina e destinados a confirmá-la”.

Joan Tronto (1987, p. 644-646) entende que a ética do cuidado descrita por Gilligan deve ser um foco de atenção para as feministas, mas critica o fato de Uma voz diferente deixar espaço para ser interpretada como prova da existência de uma "moralidade das mulheres". Assim, a autora sustenta que o debate sobre ética do cuidado deveria centrar-se não nas diferenças entre os sexos, mas no discurso sobre sua adequação como teoria moral em contraponto às vertentes majoritárias (TRONTO, 1987, p. 658). Em compensação, afirma que os limites da teoria de Gilligan impediram que ela cumprisse a proposta de transformar o lugar socialmente designado às mulheres e às demais pessoas que cuidam e se importam (TRONTO, 1993, p. 96).

Tendo em vista essa crítica e a necessidade de redefinir "fronteiras morais" (moral boundaries), Joan Tronto e Berenice Fisher (1990, p. 40) sugerem que o cuidado seja visto como uma "atividade da própria espécie, que inclui tudo o que fazemos para manter, continuar e reparar nosso 'mundo' para que possamos viver nele da melhor forma possível". No centro da definição das autoras, o cuidado é visto como um processo composto por quatro fases entrelaçadas (intertwining phases), sendo elas: importar-se com (caring about); tomar conta de (taking care of); oferecer cuidado (caregiving); e receber cuidado (care-receiving). Cada uma dessas fases exige, em diferentes níveis, fatores como tempo, recursos materiais, conhecimento e habilidades (TRONTO; FISHER, 1990, p. 41).

Em termos elucidativos, e incluindo as dimensões morais adicionadas posteriormente por Tronto (2007, p. 288), o importar-se com (caring about) é a fase em que as pessoas selecionam as características do ambiente que sustentam a sobrevivência e bem-estar, envolvendo a responsabilidade pelo trabalho que precisa ser feito, sem que haja limite de tempo para isso; tomar conta de (taking care of) envolve a necessidade de iniciar e manter atividades de cuidado, exigindo a qualidade moral de ser atencioso e que a pessoa seja capaz de julgar qual ação ela deve tomar em cada momento; oferecer 
cuidado (caregiving) compreende o trabalho concreto de manter e reparar o mundo, com maior comprometimento de tempo, bem como a exigência de um conhecimento mais detalhado e empírico, pois quem cuida precisa estar sempre pronto para alterar sua estratégia de cuidado; por fim, receber cuidado (care-receiving) é a resposta daqueles para os quais o cuidado é dirigido, cuja problemática está em encontrar um denominador comum que satisfaça as necessidades da pessoa que cuida e da pessoa que é cuidada (FISHER; TRONTO, 1990, p. 41-45).

Essa definição desafiou as divisões disciplinares que ligavam o cuidar de si como uma categoria psicológica, o cuidar de outros como uma categoria sociológica e o cuidar do planeta como uma categoria política ou econômica (TRONTO, 2007, p. 288). Assim, entender que o cuidado diz respeito não só a atividades altruístas, mas também a ter responsabilidade e comprometimento com a boa execução do trabalho, de forma a responder às necessidades elencadas para serem satisfeitas, permite mudar a visão do mundo, que deixa de ser "constituído de indivíduos autônomos que perseguem fins racionais e projetos de vida" e passa a ser feito também de "pessoas emaranhadas em redes de interesse e comprometidas com o atendimento das necessidades de outras pessoas ao seu redor" (TRONTO, 2007, p. 289). ${ }^{21}$

Carol Gilligan e Joan Tronto são expoentes da vertente de reflexão da ética do cuidado. Segundo Helena Hirata (2011a, p. 87-88), as duas autoras se aproximam por debaterem uma 'política do cuidado' no sentido de que a sociedade precisa cuidar de indivíduos, de modo a permitir que o cuidado se desvencilhe da carga de gênero que lhe é atribuída. Ou seja, suas formulações teóricas evidenciaram que "todas as atividades, incluindo aquelas que pensamos como políticas, envolvem uma dimensão de cuidado porque, além de atuar, nós precisamos nos auto-sustentar enquanto atores" (FISHER; TRONTO, 1990, p. 39, tradução nossa).

Para Patricia Paperman e Sandra Laugier (2011, p. 13-14), encontra-se nas autoras alinhadas à vertente ética do cuidado, começando por Gilligan e Tronto, uma crítica feminista das teorias morais e políticas majoritárias, notavelmente à teoria da

\footnotetext{
${ }^{21}$ Tronto (2007, p. 289) alerta, porém, para a necessidade de o cuidado não se limitar a um conceito, pois tendo apenas dimensões normativas ele pode ser instrumentalizado para explorar e dominar, como aconteceu na época colonial, que se apoiou no discurso do "cuidado" dos nativos que precisavam ser civilizados. Por isso, a autora defende que o cuidado seja orientado pelo propósito de tornar a sociedade o mais democrática possível (TRONTO, 2007, p. 290).
} 
justiça de John Rawls ${ }^{22}$ - que monopoliza a definição de justiça e nega a voz própria aos sujeitos que exprimem uma compreensão das questões morais que se afasta da voz dominante. O cuidado, assim, constituiria uma subversão política ${ }^{23}$, tendo como interesse permitir que vozes subalternas apareçam e que interfiram na decisão sobre o que tem ou não lugar no debate público (PAPERMAN; LAUGIER, 2011, p. 14).

Nesse sentido, Paperman e Pascale Molinier (2011, p. 190) explicam que a concepção universalista de justiça não teve sucesso em oferecer garantias para as reivindicações das categorias socialmente minoritárias, o que serve de ponto de partida para a ética do cuidado, que parte de um sujeito que "pensa e age a partir de uma experiência concreta materialmente estruturada pela atenção e atividades realizadas para os outros" (PAPERMAN; MOLINIER, p. 190). Segundo as autoras, prestar atenção às pessoas que trabalham com cuidado, sem desmerecer nem idealizá-las, permite colocar em evidência seu conhecimento sobre as formas de vulnerabilidade, de fragilidade humanas em todas as fases da vida, colocando em cheque ideais de autossuficiência que ludibriam a sociedade (PAPERMAN; MOLINIER, 2011, p. 191).

Portanto, o potencial da discussão em torno da ética do cuidado passa pela percepção de que as escolhas que definem as responsabilidades pelo cuidado - "quem cuida de quem" - estabelecem a maneira como uma determinada sociedade é organizada, de modo que pensar no cuidado é pensar na distribuição social e política das responsabilidades, permitindo repensar a justiça em nível mundial (MOLINIER; PAPERMAN, 2015, p. 47). Justamente a dificuldade de fazer tais reflexões levou o mundo a enfrentar o que hoje chama-se de crise do cuidado, que também será alvo deste capítulo.

\footnotetext{
${ }^{22}$ Ref.: Uma teoria da Justiça de John Rawls (2011). Sem pretensão de aprofundamento, cabe esclarecer que a teoria da justiça de Rawls, uma das mais influentes do século XX, assume a família como um núcleo de relações humanas justas, negligenciado a distribuição de poder, responsabilidade e privilégio associada às relações de gênero dentro dela (OKIN, 1989, p. 9); ele chegou a responder às críticas feministas, em especial de Susan Moller Okin (1989), afirmando que os princípios da justiça, por mais que não se apliquem diretamente à vida interior da família, continuariam capazes de proteger direitos e liberdades de seus membros e que há conceitos apropriados de justiça - que não são políticos - que se aplicariam diretamente ao interior de grupos e associações (RAWLS, 2001, p. 163-164). Ainda assim, as críticas feministas se mantiveram, entendendo fundamentalmente que se a família é a base da estrutura para o desenvolvimento moral, e esta não é justa em relação ao gênero, então toda a teoria de Rawls parece ser construída sobre fundamentos incertos (KYMLICKA, 2006, p. 345).

${ }^{23}$ Nesse sentido, as autoras defendem o seguinte: "Não se trata de voltar à ideia de que as mulheres seriam a origem - moral - do mundo, ou de essencializar qualquer coisa no registro moral de acordo com o sexo, mas dizer que muito do que hoje se entende por "mulher" foi constituído nas práticas do cuidado; mesmo que essas "mulheres" não tenham tido escolha, é pelo menos sensato considerar que essas práticas e experiências são também experiências de mulheres" (PAPERMAN; LAUGIER, 2011, p. 26).
} 
Com isso em mente, passo agora à descrição das outras formas de abordagem do cuidado, que permitirão organizar de maneira mais completa a compreensão desse conceito que se mostra muito mais amplo do que a priori pode-se deduzir. No próximo item, tratarei do cuidado enquanto trabalho, abordando em especial a perspectiva sociológica sobre o tema, que abre espaço para uma análise concreta sobre como as relações de gênero em torno do cuidado se desdobram socialmente e as consequências disso, dando continuidade à edificação da base teórica desta tese.

\subsection{CUIDADO COMO TRABALHO}

A problematização do cuidado como trabalho ganhou relevância no Brasil graças às pesquisas de Helena Hirata, professora que influenciou gerações de estudantes brasileiras ao redor do tema trabalho e gênero. Essa linha de pensamento é fruto dos estudos feministas materialistas dos anos 1970 e 1980, que introduziram as "categorias do sexo e de relações sociais de sexo no âmago da análise das relações de trabalho, assalariado e doméstico", de maneira a contribuir para "conhecimentos renovados sobre o trabalho" (HIRATA, KERGOAT, 2008a, p. 47-48).

Falar em cuidado no cotidiano remete normalmente às atividades de dedicar tempo e atenção a crianças, idosos, pessoas com deficiência ou enfermos, ou seja, um trabalho cujo foco é uma população tida como dependente. Tratarei mais adiante da crítica à difundida contraposição entre o "ser independente" e a dependência atrelada a determinados grupos sociais, todavia, neste momento, a atenção estará voltada à profunda imbricação entre trabalho de cuidado e o atual sistema sexo/gênero, edificada sobre uma divisão sexual do trabalho que designa o cuidado às mulheres (FISHER; TRONTO, 1990, p. 35-36).

Desde a década de 1970, as teóricas feministas tinham dentre seus principais enfoques o debate sobre o reconhecimento do trabalho doméstico como trabalho. Conforme pontuado por Guita Grin Debert e Mariana Marques Pulhez (2017, p.16-17), a “oposição entre trabalho produtivo e trabalho reprodutivo marcava a diferença entre a produção de bens e serviços com valor econômico de mercado e o conjunto de cuidados necessários para a sobrevivência e sustento da vida", atividades estas predominantemente realizadas por mulheres, cujo valor econômico não é reconhecido. 
Nos estudos das feministas materialistas na França e no Brasil, aqui citadas Helena Hirata e Danièle Kergoat (2007, p. 596), a divisão sexual do trabalho era o principal eixo teórico cuja ambição, muito além de denunciar as desigualdades entre os sexos, era de repensar o "trabalho", ancorado na ideia de que "trabalho doméstico era um 'trabalho' e que, portanto, a definição deste deveria obrigatoriamente incluir aquele”. Buscavam, desse modo, não somente articular as esferas produtiva e reprodutiva, mas centrar a ideia de trabalho na produção do viver (HIRATA; KERGOAT, 2007, p. 596).

A compreensão da realidade das relações de trabalho, nos termos de Iris Marion Young (1981, p. 50-51), passa necessariamente por uma abordagem feminista e pela elevação da categoria da divisão do trabalho entre os sexos a uma posição tão fundamental quanto classe. Uma análise do capitalismo a partir da divisão sexual do trabalho permite constatar que a marginalização das mulheres e seu funcionamento como força de trabalho secundária é uma característica fundamental para o sistema, ou seja, que as formas específicas de opressão de gênero que nele existem são essenciais à sua natureza (YOUNG, 1981, p. 58, 61).

É importante conceber que o trabalho de cuidado é uma tarefa de gênero, designada prioritariamente às mulheres, cujo desempenho não decorre de algum tipo de ligação ou vocação natural, nem é somente resultado da socialização das mulheres, mas decorre da atribuição cultural do trabalho reprodutivo doméstico não remunerado às mulheres, historicamente surgida da relação dialética entre patriarcado e capitalismo (SCHULTZ LEE, 2010, p. 649). Assim, conforme Kirsten Schultz Lee (2010, p. 649), identificar o trabalho de cuidado como "natural" das mulheres é uma forma de disfarçar a desigualdade material subjacente da divisão sexual do trabalho, reforçando a segregação ocupacional e a discriminação salarial.

Logo, o trabalho de cuidado não remunerado realizado pelas mulheres não pode ser intuído como um ato motivado simplesmente por amor, devendo-se considerar as dimensões coercitivas que o envolvem; ao mesmo tempo, é preciso incluir as emoções nas análises das atividades de cuidado que são remuneradas (SCRINZI, 2017, p. 107).

Com esse enfoque, a obra de Arlie Hochschild (1979, p. 561) é um referencial teórico, em especial sua abordagem do que chamou de "trabalho emocional" (emotion work), referindo-se ao "ato de tentar alterar em grau ou qualidade uma emoção ou sentimento" que ela observou no exercício de profissões como de secretária - que deve 
estar sempre alegre -, ou de professor - que deve gostar igualmente de todos os estudantes. Esse controle emocional e o enquadramento na postura exigidos por determinadas convenções sociais, segundo Hochschild (1979, p. 563), é um trabalho que demanda dos indivíduos forma contínua e particular. A autora, então, conclui:

O sentimento convencionalizado pode vir a assumir as propriedades de uma mercadoria. Quando profundos gestos de troca entram no setor de mercado e são comprados e vendidos como um aspecto da força de trabalho, os sentimentos são comodificados. (...) No entanto, a comodificação do sentimento pode não ter relevância igual para todas as classes sociais. Pode ser mais relevante para a classe média do que para a classe trabalhadora. A forma como cada classe socializa seus filhos pode, além disso, prepará-los para futuras demandas pela habilidade de administrar emoções (HOCHSCHILD, 1979, p. 569).

Angelo Soares (2012, p. 57) complementa o raciocínio, afirmando que o trabalho emocional é crucial para a realização e a compreensão do trabalho de cuidado, uma vez que é perpassado por múltiplas relações sociais e gira em torno das necessidades de outras pessoas, envolvendo afetos e outras emoções, positivas ou não. Segundo ele, para cuidar de alguém, a trabalhadora coloca em prática inúmeras qualificações que permanecem invisíveis e têm pouco reconhecimento social, mas quando essas qualificações não são mobilizadas, sua ausência é imediatamente sentida (SOARES, 2012, p. 57).

Destarte, o trabalho de cuidado inclui tanto tarefas estritamente materiais como limpar o chão, lavar a louça ou preparar refeições -, quanto tarefas que implicam um compromisso relacional (SCRINZI, 2016, p. 107). Consequentemente, traz ambiguidades que são éticas, psicológicas e também políticas, derivadas da "proximidade entre os corpos, presença da sexualidade, morte, excitação de afetos, recorrência de relações de dominação que não ocorrem jamais sem violência e sem humilhação" (DAMAMME ; HIRATA ; MOLINIER, 2017, p. 7, tradução nossa).

De acordo com Danièle Kergoat (2016, p. 17), o cuidado não se resume a uma atitude de atenção, mas é um trabalho que abrange "um conjunto de atividades materiais e de relações que consistem em oferecer uma resposta concreta às necessidades dos outros". Por isso, ela o define como "uma relação de serviço, apoio e assistência, remunerada ou não, que implica um sentido de responsabilidade em relação à vida e ao bem-estar de outrem" (KERGOAT, 2016, p. 17). Assim, o cuidado enquanto atividade concreta de trabalho exige uma análise imbricacional para ser apreendido, pois nele 
acontecem interações constantes, marcadas pela consubstancialidade ${ }^{24}$ entre gênero, raça e classe (KERGOAT, 2016, p. 19).

$\mathrm{Na}$ tentativa de somar a abordagem psicológica e a sociológica à concepção do cuidado enquanto trabalho, Pascale Molinier (2012, 30-41) propõe cinco descrições: "cuidado como gentleness", ou seja, o cuidado como resposta adequada à fragilidade do outro, "em situações que envolvem interações e onde o provedor do care sente-se investido de uma responsabilidade", o que demanda sensibilidade e capacidade de improvisar; "cuidado como um savoir-faire discreto", levando em conta que, quando bem feito, o trabalho de cuidado não se nota, pois quem cuida antecipa as necessidades da pessoa cuidada; "cuidado como trabalho sujo", dimensão que envolve o contato com fluidos corporais e evacuação de dejetos da vida cotidiana, atividades normalmente segregadas e socialmente invisibilizadas; "cuidado como trabalho inestimável", representando atividades que não são passíveis de precificação, mas que são imprescindíveis para a pessoa cuidada, como a presença e o sorriso; e "cuidado como narrativa ética", que representa a necessidade de politizar os relatos que envolvem as relações de cuidado, de modo não a idealizá-los, mas inscrevê-los em uma trama teórica em busca de mais justiça.

De maneira concreta, voltando a atenção especificamente para o cuidado enquanto trabalho remunerado, as características a ele atreladas são mundialmente muito semelhantes. A pesquisa comparativa entre Brasil, França e Japão, de Helena Hirata (2011b, p. 200, tradução nossa), mostra "uma tendência ao aumento das ocupações relacionadas aos cuidados, especialmente no atendimento domiciliar, inclusive em tempos de crise". Embora diferentes, o aspecto comum entre trabalhadoras do cuidado nos três países é a precariedade em sua carreira profissional e sua exclusão dos outros setores do mercado de trabalho ou dos empregos mais qualificados (HIRATA; MAKRIDOU; MATSUO, 2017, p. 51).

Parte dessa desvalorização do trabalho de cuidado está atrelada à ideia de que ele é composto de atividades "naturais", que "todo mundo pode fazer", o que é combatido por Pascale Molinier (2017, p. 55-59), que contesta a hierarquização e o sistema de reconhecimento social das profissões, utilizando, para isso, sua metodologia de análise do "trabalho vivido", inspirada na ergonomia e na psicodinâmica do trabalho.

\footnotetext{
${ }^{24}$ Para aprofundamento nos debates sobre consubstancialidade e interseccionalidade, inclusive para a confrontação das nomenclaturas, cf.: HIRATA, 2014a.
} 
Ela explica que o aumento da especialização foi estabelecido como um critério de profissionalização, mas que esse modelo de especialidade não pode ser transposto ao trabalho de cuidado, em especial porque as emoções e o afeto, nesse caso, são as formas como a ética profissional se revela nesse campo (MOLINIER, 2017, p. 61-62).

Desse modo, "profissionalismo" para uma cuidadora que realiza "trabalho sujo" é "preocupar-se com a pessoa cujas nádegas sujas estão sendo lavadas", ou seja, é executar bem seu serviço sem reificar o ser humano que está sendo cuidado (MOLINIER, 2017, p. 62, tradução nossa). A autora sustenta, então, que a técnica é uma dimensão presente no trabalho de cuidado, mas ela se soma ao que suas entrevistadas chamam de "trabalhar com o coração", que envolve a capacidade de empatia, atenção e presença que no cotidiano não são fáceis de serem mantidas entre as partes (MOLINIER, 2017, p. 63). Para exemplificar o nível de exigência dessas trabalhadoras, que não é captado pela legislação, Molinier (2017, p. 64) menciona o fato de as cuidadoras normalmente regularem seu equilíbrio emocional por meio do absenteísmo.

Por outro enfoque, considerando a responsabilidade pelo cuidado não remunerado, Bila Sorj e Adriana Fontes (2012, p. 107) apontam para a existência de uma notável vinculação entre as desigualdades no mercado de trabalho e no acesso diferenciado aos suportes de cuidado, sejam aqueles providos pelo Estado e pelo mercado ou na forma como se dá a divisão do trabalho dentro do lar. De acordo com as autoras, "a carência de mecanismos que permitam desfamiliarizar os cuidados ajudam a perpetuar a pobreza, uma vez que limita a inserção das mulheres no mercado de trabalho e, portanto, maior renda domiciliar" (SORJ; FONTES, 2012, p. 107).

Por fim, Pascale Molinier e Patricia Paperman (2015, p. 46) salientam que as relações de cuidado são interpessoais, independentemente se o trabalho for remunerado ou não, fazendo também parte "de um processo social mais amplo, que comporta diferentes fases ou momentos morais que envolvem protagonistas múltiplos (indivíduos, grupos e instituições), em relações frequentemente hierarquizadas”. Assim, defendem o cuidado como processo, abrangendo "o que se passa no nível da relação de cuidado direta (caregiving), a maneira como as necessidades de cuidado são consideradas em âmbito mais amplo (institucional, político) e como são considerados os meios para atendê-las" (MOLINIER; PAPERMAN, 2015, p. 46). 
Dessa maneira, os estudos em torno do trabalho de cuidado mostram-no também como relação social (rapport social) - englobando relações de trabalho, gênero, raça e também questões intersubjetivas, como afetos e desafetos -, que é normalmente encoberta porque traz à luz não só o excesso de intimidade e o lado "sujo" desse tipo de trabalho, mas também as engrenagens ocultas da dominação (HIRATA; MOLINIER, 2012, p. 11). Por isso, no nível político, a descrição do trabalho de cuidado "contém uma dimensão particularmente subversiva", pois torna público o que historicamente se tenta esconder ou condenar, revelando a história de mulheres pobres e isoladas que podem ser consideradas heroínas por lutarem para garantir seu sustento e o de seus filhos, ao mesmo tempo em que "ajudam a tornar nosso mundo habitável” (HIRATA; MOLINIER, 2012, p. 12).

As perspectivas apresentadas acerca do trabalho de cuidado colocam em destaque a função central dessas atividades no cotidiano da vida humana, sejam elas realizadas de forma remunerada ou não, dentro das casas, em instituições públicas ou privadas, por pessoas da família, babás, cuidadoras de idosos, trabalhadoras domésticas, técnicas ou auxiliares de enfermagem. ${ }^{25}$ Ainda assim, para a execução dos objetivos propostos por esta tese, importante incorporar as ferramentas críticas da Economia Feminista, em especial porque a Economia é a disciplina que goza, na atualidade, de maior poder social (CARRASCO, 2014, p. 17), fazendo com que argumentos ditos "econômicos" tenham grande influência e sejam usados para justificar medidas de redução dos direitos trabalhistas, o aumento das formas de exploração por meio da precarização e da redução de serviços públicos. É sobre esse tema que o próximo tópico se ocupará.

\footnotetext{
${ }^{25}$ Cabe chamar atenção para a existência da segregação ocupacional por sexo, realidade que, dentro de outros fatores, pode ser vista na maior concentração de mulheres em profissões relacionadas ao cuidado ou que exigem habilidades consideradas "femininas". Não é foco deste trabalho, por isso não me aprofundarei na questão, mas já tratei dela em minha dissertação de mestrado (VIEIRA, 2014). Para um panorama sobre o tema, cf.: YANNOULAS, 2003.
} 


\subsection{CUIDADO NA ECONOMIA FEMINISTA}

De início, com intuito de apresentar a Economia Feminista e situar o pensamento por ela elaborado, tomarei como referência as explicações de Cristina Carrasco, uma das autoras de maior referência nessa linha de estudos. Segundo ela, o que hoje se chama Economia Feminista tem uma história que começa no século XIX, quando as precursoras passaram a fazer o enfrentamento dos pensadores clássicos nos debates em torno do emprego feminino, defendendo que as mulheres das classes operárias precisavam de renda, uma vez que os salários masculinos não eram suficientes para manter a família (CARRASCO, 2014, p. 15).

O desenvolvimento da disciplina deu-se a partir dos 1970, coincidindo com a segunda onda do feminismo ${ }^{26}$, quando o "debate sobre o trabalho doméstico" teve início no movimento feminista e, posteriormente, na academia (CARRASCO, 2014, p. 15). Nessa chave de raciocínio, Carrasco $(2014$, p. 16) frisa que apesar de "economia" ter sua origem na palavra grega oikosnomia, que significava "gestão da casa", o trabalho realizado dentro da esfera doméstica não foi reconhecido como categoria econômica de modo que, para a Economia, somente o trabalho mercantil é considerado trabalho.

Assim, a Economia Feminista dedica-se a apresentar uma visão do mundo mais realista do que as visões oferecidas pela maioria das escolas do pensamento econômico ${ }^{27}$, propondo incorporar as experiências das mulheres, o que permite "reformular conceitos centrais de análise econômica, desenvolver novos quadros analíticos e elaborar políticas públicas que respondam à realidade" de todas as pessoas (CARRASCO, 2013, p. 42). Oferece, dessa forma, uma perspectiva que "amplia o circuito de trabalho, integrando o que pode ser designado como economia do cuidado", de modo a incluir a economia não monetizada nos circuitos econômicos (CARRASCO, 2014, p. 32). ${ }^{28}$

\footnotetext{
${ }^{26}$ Para uma breve exposição sobre as ondas do feminismo, cf.: VENCATO; VIEIRA, 2014. Ou, com maior aprofundamento, cf.: PISCITELLI, 2009.

${ }^{27}$ Sobre a história do pensamento econômico, cf.: HUNT; LAUTZENHEISER, 2011 e SCREPANTI; ZAMAGNI, 2012.

${ }^{28} \mathrm{O}$ processo que considera tanto o trabalho mercantil quanto o trabalho doméstico e de cuidado é denominado "circuito amplo do trabalho", o qual evidencia a relação dinâmica entre produção e reprodução de mercadorias e reprodução da força de trabalho (CARRASCO, 2014, p. 33). Para explicação pormenorizada desse circuito, que inclui o diagrama das trocas entre os âmbitos da produção mercantil e do desenvolvimento humano, cf:: PICCHIO, 2005a.
} 
Ainda que deixados de lado pelas teorias econômicas majoritárias, o trabalho doméstico e a gestão dos lares "reproduzem e cuidam de toda a população e, em particular, reproduzem a força de trabalho diária e geracional necessária à subsistência do sistema de produção capitalista", uma vez que "este sistema econômico não tem a capacidade de reproduzir a força de trabalho sob suas próprias relações de produção" (CARRASCO, 2013, p. 44). Caso contrário, de acordo com Carrasco (2013, p. 44), toda a população deveria ter a possibilidade de se reproduzir apenas com seu salário - que precisaria ser exorbitante -, sem a necessidade de realizar nenhum outro tipo de trabalho no âmbito privado.

Isso evidencia, nas palavras da autora, que a partir da esfera doméstica é fornecida às empresas "uma força de trabalho abaixo de seu custo real, já que no custo de reprodução dessa mão-de-obra as energias e o tempo dedicado a reproduzi-la, que vem dos lares, não são levados em consideração" (CARRASCO, 2013, p. 45). Por conseguinte, desvalorizar o trabalho doméstico e de cuidado garante que seu produto - a força de trabalho - seja também desvalorizado, podendo-se concluir que

(...) parte do lucro da empresa privada vem do uso da unidade doméstica - tratada como uma caixa preta - e não apenas da exploração no local de trabalho, como Karl Marx pensava, entre outros. O capitalismo se constrói, assim, sobre uma imensa massa de trabalho não assalariado, e nem baseada em relações contratuais, que torna possível a acumulação do capital (CARRASCO, 2013, p. 45). ${ }^{29}$

A definição de "cuidado" para a Economia Feminista, de acordo com Cristina Carrasco (2013, p. 40), carrega a dificuldade de se escolher uma terminologia que reflita a complexidade desse processo e toda a carga teórica, histórica e social que o acompanha. Segundo ela, a jornada em torno do conceito começou com o debate sobre a natureza do trabalho doméstico e sua relação com o modo de produção capitalista, no qual feministas marxistas sustentavam a tese de que o trabalho doméstico respondia a uma necessidade do capitalismo, uma vez que integrava a reprodução da força de trabalho; trata-se, pois, de um debate que tinha caráter eminentemente econômico e que enfatizava a reprodução

\footnotetext{
${ }^{29}$ Excerto original: "Por tanto, se puede fácilmente concluir que parte del beneficio de la empresa privada proviene de la utilización de la unidad doméstica - tratada como caja negra - y no solo de la explotación en el puesto de trabajo, como pensaba Carlos Marx, entre otros. El capitalismo se construye así sobre una inmensa masa de trabajo no asalariado ni basado en relaciones contractuales, que hace posible la acumulación de capital (...)."
} 
da força de trabalho, assim como deixava de lado a satisfação das necessidades humanas (CARRASCO, 2013, p. 40).

De acordo com Susan Himmelweit (1995, p. 4), o argumento na época - final dos anos 1960 - era que grande parte das tarefas domésticas para as quais as mulheres dedicavam seu tempo eram uma forma de trabalho. No entanto, a autora registra sua crítica ao fato de a definição de trabalho utilizada para embasar essa afirmação, ainda que deixasse claro que o trabalho doméstico não é remunerado e não produz mercadorias para o mercado, estava tomada acriticamente da caracterização dominante do trabalho na economia remunerada, ou seja, estava atrelada à forma dominante do trabalho capitalista assalariado na fábrica.

Na década seguinte, ganhou espaço a Campanha por um Salário para o Trabalho Doméstico (Wages for Housework), fundada em 1972, que, articulando e criticando categorias marxianas, buscava fazer com que a análise da "questão das mulheres" se transformasse na análise do trabalho doméstico como fator crucial para a definição de sua exploração no capitalismo (FEDERICI, 2012, prefácio). Segundo Silvia Federici (2017a, p. 10-11), que fazia parte do movimento e tornou-se também referência na área da Economia Feminista, as integrantes queriam refutar a ideia, sustentada por marxistas ortodoxos, de que o trabalho doméstico era um remanescente do passado, que não desempenhava "nenhuma função na organização capitalista do trabalho" e que a subordinação das mulheres podia ser atribuída à sua exclusão da "produção socialmente necessária". 30

A principal preocupação do movimento era demonstrar que, historicamente, a questão da "produtividade" está ligada à luta pelo poder social, denunciando que o capitalismo requer trabalho reprodutivo não remunerado para conter o custo da força de trabalho (FEDERICI, 2012, introdução). De modo efetivo, a campanha procurou abrir um espaço de mobilização feminista internacional que poderia forçar os Estados a

\footnotetext{
${ }^{30}$ De acordo com Federici (2017a, p. 11), essa ideia defendida por marxistas ortodoxos era baseada em $A$ origem da família, da propriedade privada e do Estado, de Friedrich Engels. Nessa obra, Engels (1984), a partir de referenciais antropológicos sobre os diferentes sistemas de parentesco, mostra a relação entre o surgimento da propriedade privada, sua atribuição ao "chefe" da família patriarcal e a dominação masculina. Os limites apontados pelas feministas ao texto de Engels dizem respeito à suposição de que haveria um padrão universal de família e à naturalização da divisão sexual do trabalho (ARAÚJO, 2000, p. 66). Ainda assim, Maria Lygia Quartim de Moraes (2000, p. 89) não descarta que nele a "condição social da mulher ganha um relevo especial, pois, a instauração da propriedade privada e a subordinação das mulheres aos homens são dois fatos simultâneos, marco inicial da luta de classes", momento em que o marxismo parece se abrir para a "opressão específica".
} 
reconhecerem "que o trabalho doméstico é trabalho - ou seja, uma atividade que deveria ser remunerada, pois, contribui para a produção da força de trabalho e produz capital, permitindo que todas as outras formas de produção aconteçam" (FEDERICI, 2012, introdução, tradução nossa).

Posteriormente, parte da literatura abandonou o termo "trabalho doméstico" e passou a usar "trabalho reprodutivo", em oposição ao trabalho mercantil, dito "produtivo" (CARRASCO, 2013, p. 41). Forte entre as feministas italianas, o conceito de reprodução social foi desenvolvido para que expressasse "o complexo processo de tarefas, trabalhos e energias, cujo objetivo seria a reprodução da população e das relações sociais e, em particular, a reprodução da força de trabalho", incluindo o trabalho doméstico de produção de bens materiais para o suprimento físico das pessoas, mas também o cuidado direto e a gestão das relações emocionais ${ }^{31}$ (CARRASCO; BORDERÍA; TORNS, 2011, p. 31).

Foi colocando a reprodução da vida no centro da análise do capitalismo que Silvia Federici (2017a) elaborou uma das mais aclamadas obras da Economia Feminista, Calibã e a Bruxa, publicada em 1998, que faz a reconstrução histórica do desenvolvimento do sistema e aborda a necessidade intrínseca a ele de realizar e perpetuar a separação entre os sexos dos trabalhos voltados para o mercado e daqueles voltados para suprir a necessidade das pessoas, tanto na acumulação original quanto em outros estágios. Nas palavras da autora:

\begin{abstract}
Observando o desenvolvimento capitalista do ponto de vista dos não assalariados - que trabalham nas cozinhas, nos campos e nas plantações, fora de relações contratuais, cuja exploração foi naturalizada, creditada a uma inferioridade natural -, Calibã e a bruxa desmistifica a natureza democrática da sociedade capitalista e a possibilidade de qualquer 'troca igualitária' dentro do capitalismo. Seu argumento é o de que o compromisso com o barateamento do custo da produção do trabalho, ao longo do desenvolvimento capitalista, exige o uso da máxima violência e da guerra contra as mulheres, que são o sujeito primário dessa produção (FEDERICI, 2017a, p. 13-14).
\end{abstract}

\footnotetext{
${ }^{31}$ David Ricardo e, posteriormente, Marx atrelaram reprodução social à reprodução da força de trabalho, necessária para que o próprio capital se reproduza, pois é o trabalho que permite a criação do mais-valor e, portanto, o acúmulo de riqueza (MERCURE; SPURK, 2005). Entretanto, o trabalho doméstico necessário para reproduzir a força de trabalho não foi considerado pelo referido enfoque, como explica Silvia Federici (2017b, p. 95-96): "Marx indica que a reprodução do trabalhador é parte essencial e condição da acumulação de capital. Não obstante, apenas a concebe sob o aspecto do 'consumo' e coloca sua realização somente dentro do circuito da produção de mercadorias. Os trabalhadores - segundo Marx - usam seus salários para comprar os bens necessário à sua vida e, ao consumi-los, se reproduzem. (...) Em nenhuma parte de $O$ Capital, Marx reconhece que a reprodução da força de trabalho envolve o trabalho não remunerado das mulheres - preparar comida, lavar a roupa, criar os filhos, fazer amor. Pelo contrário, ele insiste em retratar o assalariado como um reprodutor de si mesmo".
} 
De forma resumida, o argumento de Federici (2017a, p. 26, 30) é de que a caça às bruxas dos séculos XVI e XVII "constituiu um aspecto central da acumulação e da formação do proletariado moderno", tendo sido fundamental para o desenvolvimento do capitalismo, tanto quanto a colonização e a expropriação do campesinato europeu de suas terras. Por conseguinte, a acumulação primitiva ${ }^{32}$ - entendida como processo fundacional que revela as condições estruturais que tornaram possível a sociedade capitalista - inclui o "desenvolvimento de uma nova divisão sexual do trabalho", a "construção de uma nova ordem patriarcal, baseada na exclusão das mulheres do trabalho assalariado" e a "mecanização do corpo proletário e sua transformação, no caso das mulheres, em uma máquina de produção de novos trabalhadores” (FEDERICI, 2017 a, p. 25-26).

Diante disso, a conclusão da autora é de que o capitalismo está necessariamente ligado ao sexismo e ao racismo, porque utiliza-se da "difamação" da "natureza" daqueles a quem explora enquanto sistema econômico, como mulheres, negros e migrantes, para “justificar e mistificar as contradições incrustadas em suas relações sociais, que são a promessa de liberdade frente à realidade da coação generalizada, e a promessa de prosperidade frente à realidade de penúria generalizada" (FEDERICI, 2017a, p. 37).

Em proposta semelhante, Antonella Picchio (1992) construiu sua teoria com base na proposta de formular uma visão do sistema econômico capaz de abarcar o processo de reprodução social e da população, em particular das camadas mais pobres. Segundo ela, o processo de reprodução - tanto do sistema quanto das pessoas - requer mercadorias, produzidas pelo trabalho assalariado, mas também requer trabalho não remunerado necessário para cozinhar alimentos, limpar a casa, lavar as roupas e cuidar de corpos, trabalho este que é geralmente ignorado pelas análises do sistema econômico e dos sistemas de contabilidade nacional (PICCHIO, 2005b, p. 24).

Assim, as análises da Economia Feminista apresentadas até agora atentam à experiência das mulheres e reconhecem os valores próprios do trabalho doméstico como

\footnotetext{
32 Termo usado por Marx (2013, p. 786), em O Capital, para denominar o "processo histórico de separação entre produtor e meio de produção" que sustenta o desenvolvimento das relações capitalistas, constituindose "da separação entre o trabalhador e a propriedade das condições de realização de seu trabalho, processo que, por um lado, transforma em capital os meios sociais de subsistência e de produção e, por outro, converte os produtores diretos em trabalhadores assalariados". Acrescente-se que, se para Marx a acumulação primitiva estava marcadamente ligada à pré-história do capitalismo, muitos autores desde Rosa Luxemburgo atentam para sua continuidade ao longo de toda a geografia histórica do capitalismo (HARVEY, 2013, p. 291-292).
} 
valores humanos fundamentais, o que era invisibilizado pelo peso do mercado na sociedade patriarcal capitalista (CARRASCO, 2013, p. 41). Para algumas autoras, o aprofundamento do debate sobre o conteúdo das atividades realizadas no âmbito doméstico fez levantar aspectos subjetivos e o importante papel do "trabalho de cuidados", caracteristicamente seus elementos emocionais, que não podem ser transferidos para o mercado em sua totalidade (CARRASCO, 2017).

De acordo com Carrasco (2013, p. 47), ainda que as primeiras tentativas de conceituar o trabalho de cuidado tenham vindo da Sociologia, economistas feministas precursoras escreveram sobre o tema nos anos 1990, como Nancy Folbre e Susan Himmelweit. Esta última, em artigo de 1995, afirma que o reconhecimento da contribuição das atividades de cuidado para o bem-estar social, de forma a serem incorporadas nas análises econômicas, só é possível se acontecer fora da polarização trabalho/não-trabalho (HIMMELWEIT, 1995, p. 1). Em suas palavras:

Ao invés de reforçar essa dicotomia, insistindo em que, para serem reconhecidas as contribuições das mulheres para a sociedade, elas precisam se encaixar em uma categoria concebida em torno dos modos pelos quais os homens entram em uma economia capitalista, precisamos transcendê-la. Tanto em nosso trabalho teórico quanto na prática, podemos ser capazes de construir um futuro alternativo, deliberadamente criando um espaço para aquelas atividades que não podem ser encaixadas em nenhum dos polos daquela dicotomia (HIMMELWEIT, 1995, p. 15-16, tradução nossa). ${ }^{33}$

Quanto à Nancy Folbre (2003), seu emblemático livro de 1994 trazia no título a pergunta “quem paga pelas crianças?" (Who pays for the kids?), que chamava atenção para como os gastos com o cuidado de si, das crianças e de outros dependentes eram distribuídos entre os membros da sociedade, deixando clara a compreensão de que o sucesso do cuidado é pré-condição para a produção de bens e serviços, mas também um objetivo em si. Assim, a obra denunciava a falta de atenção dos economistas nas relações entre homens e mulheres e entre pais e filhos, o que resultou em análises falhas sobre o desenvolvimento econômico e social (FOLBRE, 2003, p. 1). ${ }^{34}$

\footnotetext{
${ }^{33}$ Excerto original: "Rather than reinforcing this dichotomy, by insisting that if women's contributions to society are to be recognized they have to fit into a category designed around the ways in which men enter into a capitalist economy, we need to transcend it. Both in our theoretical work and in practice, we may be able to construct an alternative future by deliberately carving out a space for those activities which cannot be fitted into either pole of that dichotomy".

${ }^{34}$ Compartilhando dessa percepção, algumas autoras defendem a valoração do trabalho doméstico e a importância de visibilizá-lo por meio de algum indicador relevante em economia, especialmente o PIB,
} 
De acordo com a autora, os economistas normalmente apreciam o conceito de “capital humano", mas excluem o tempo dedicado a cuidar da nova geração da categoria macroeconômica do investimento, além de que sua visão histórica do trabalho das mulheres na família como uma atividade de responsabilidade natural ou moral contribuiu para a desvalorização da reprodução social (FOLBRE, 2003, p. 3). Ela completa seu raciocínio afirmando que:

Os custos da reprodução social, embora difíceis de estimar, são fáceis de definir. Incluem despesas diretas em favor de dependentes, como crianças, doentes, deficientes e idosos. Incluem também os custos do tempo dedicado ao cuidado desses indivíduos e à manutenção diária dos adultos. As donas de casa costumam ser descritas como "dependentes", mas, na verdade, seus maridos, assim como seus filhos, dependem fundamentalmente delas para seu cuidado e sustento (FOLBRE, 2003, p. 4 , tradução nossa). ${ }^{35}$

Consoante Cristina Carrasco (2013, p. 47), diferente do trabalho mercantil cujo objetivo é a reprodução de um bem ou serviço que permita obter lucro econômico para a empresa privada e dinheiro para a pessoa que o executa, o trabalho realizado nos lares visa a cuidar "das pessoas ao longo do ciclo de vida, com as dependências específicas que cada etapa da vida implica”. Por não estar orientado ao mercado, a economia e a política não consideram o trabalho de cuidado como objeto de estudo, ignorando que as atividades a ele relacionadas ocupam parte importante do tempo e da energia das pessoas (CARRASCO, 2013, p. 47). A autora completa:

Por causa da relevância na manutenção dos corpos, do bem-estar das pessoas, da criação e recriação da vida, a chamada economia do cuidado, ou simplesmente cuidado, é reconhecida pela Economia Feminista como a área fundamental para a qual devem ser direcionados os objetivos sociais e econômicos. Se o trabalho de cuidado tem como

como fizeram Hildete Pereira de Melo, Claudio Monteiro Considera e Alberto Di Sabbato (2007) ao calcular que os afazeres domésticos corresponderiam a 11,2\% do PIB brasileiro no período 2001-2005. No entanto, como explica Florence Jany-Catrice (2016, p. 271), as críticas a este indicador são antigas e "alertam para o fato de que muitas dimensões não monetárias e não mercantis não são consideradas pelas contas macroeconômicas (voluntariado, atividades domésticas)", mas, apesar disso, ele continua sendo usado como paradigma internacional devido a uma "cegueira coletiva", "que opera pela crença nas virtudes infinitas do crescimento econômico". Carrasco, Borderías e Torns (2011, p. 69) afirmam que a dificuldade em propor a quantificação do trabalho doméstico e de cuidado decorre do fato de isso exigir que lhe seja atribuído um valor de troca, o que impede que se reconheça "o fato de que grande parte do trabalho realizado nas casas tem um valor de uso que não fica refletido em seu valor de troca". Para aprofundamento, cf.: MÉDA, 2008 e JANY-CATRICE; MÉDA, 2011/12.

${ }^{35}$ Excerto original: "The costs of social reproduction, however difficult to estimate, are easy to define. They include direct expenditures on behalf of dependents such as children, the sick, the disabled, and the elderly. They also include the costs of time devoted to the care of these individuals, and to the daily maintenance of adults. Housewives are often described as 'dependents,' but in fact their husbands, as well as their children, are quite dependent on them for care and nurturance". 
objetivo o cuidado da vida em seus aspectos físicos e emocionais, essa atividade deve ser utilizada como referência e não a atividade desenvolvida no mercado (CARRASCO, 2013, p. 48, tradução nossa). ${ }^{36}$

Assim, por mais que a contradição social entre lucros e salários seja extremamente relevante na crítica ao sistema capitalista, base da histórica luta de classes, ampliar a perspectiva permite verificar que existem outras tensões para além desta, interessando à Economia Feminista as contradições geradas pelo patriarcado (CARRASCO, 2013, p. 50). O mais relevante dessa perspectiva, nas palavras de Carrasco (2013, p. 51), "é a possibilidade de definir uma contradição social global: a que se estabelece entre capital e vida".

Portanto, a proposta da Economia Feminista é de uma mudança de paradigma, no sentido de que o objetivo social deveria ser as pessoas e não o capital, daí a importância de colocar o cuidado no centro do debate, e não a produção de mercado, garantindo que a responsabilidade por ele torne-se social e política, não mais privada ou individual (CARRASCO, 2013, p. 42). Fazendo isso, caminha-se para revalorizar o trabalho de cuidado e romper com a centralidade do trabalho mercantil como vértice do funcionamento social e como gerador de direitos sociais (CARRASCO, 2013, p. 52).

Enfim, fechados os três primeiros eixos de análise propostos por este capítulo, resta compreender a inserção das percepções do cuidado enquanto ética, enquanto trabalho e perante a Economia nas preocupações atuais relativas ao tema. Todas essas vertentes, de uma forma ou de outra, dialogam com a apreensão em torno da chamada "crise do cuidado", motivo de alerta em quase todo o mundo, marcado pelos novos arranjos familiares, as mudanças no mercado de trabalho, pelas influências do pensamento neoliberal nos Estados e os intercâmbios econômicos e de pessoas favorecidos pela globalização. Apresento no próximo item um pouco dessa problematização, buscando marcar como países do centro e da periferia vivenciam de modos diferentes a tal crise.

\footnotetext{
${ }^{36}$ Excerto original: "Por la relevancia en el mantenimiento de los cuerpos, el bienestar de las personas, la creación y recreación de la vida, la llamada economía del cuidado o sencillamente el cuidado, es reconocida desde la economía feminista como el ámbito fundamental al cual debieran dirigirse los objetivos sociales y económicos. Si el trabajo de cuidados tiene como objetivo el cuidado de la vida en sus aspectos tanto fisicos como emocionales, dicha actividad es la que debiera servir de referente y no la actividad desarrollada en el mercado".
} 


\subsection{CRISE DO CUIDADO}

A quarta abordagem aqui proposta diz respeito às novas configurações das relações de cuidado que tem sido observadas no mundo, que geram preocupação não apenas entre o movimento e as teóricas feministas, mas em praticamente todos os setores, inclusive da mídia. A chamada "crise do cuidado" está inserida em um contexto de aumento da expectativa de vida e envelhecimento demográfico da população, principalmente nos países ricos, somado à maior presença feminina no mercado de trabalho e à escassez da oferta pública de serviços de cuidado, o que de certa forma evidenciou que "a oferta de cuidado das mulheres não é infinita como poderia se supor" (CARRASCO; BORDERÍAS; TORNS, 2011, p. 55).

Essa crise originou processos migratórios de mulheres de países do Sul que passaram a suprir a demanda por babás, cuidadoras de idosos, trabalhadoras domésticas e prostitutas nos países do Norte, formando as "cadeias globais de cuidado" identificadas por Arlie Hochschild (2000), resposta que não só retarda o tratamento da escassez do cuidado como responsabilidade pública, como ainda torna mais aguda a bipolarização do emprego feminino ${ }^{37}$.

Para melhor organizar o raciocínio, começarei buscando localizar a questão do cuidado nos atuais arranjos do capitalismo, que envolvem a financeirização das economias e a globalização, de modo a permitir compreender, ainda que brevemente, o contexto que levou à crise do cuidado, em especial nos países ricos. Em seguida, como o recorte da tese demanda, o enfoque voltar-se-á para a realidade nos países do Sul, em especial o Brasil, que nunca teve oferta pública universal de cuidados para ser retirada, mas que também enfrenta profundos problemas que envolvem a questão do cuidado.

\footnotetext{
${ }^{37}$ Helena Hirata (2009, p. 30-31) explica o fenômeno da bipolarização do emprego feminino da seguinte forma: “(...) de um lado, estabelece-se um polo constituído por mulheres executivas de profissões intelectuais superiores, categorias que se feminizam (médicas, advogadas, juízas, arquitetas, jornalistas, professoras universitárias, pesquisadoras, assalariadas do ramo da publicidade e da arte etc.); do outro, mulheres que se mantêm nas ocupações tradicionalmente femininas: funcionárias públicas, da saúde, da educação, dos serviços aos particulares, auxiliares de enfermagem, enfermeiras, professoras primárias, profissionais do home care - que atendem pessoas idosas, doentes, crianças, e que fazem o trabalho doméstico como empregadas, faxineiras etc. Um dos resultados desse duplo processo é a exacerbação das desigualdades sociais e dos antagonismos, constatada tanto entre os homens e as mulheres quanto entre as próprias mulheres (...)."
} 


\subsubsection{Cuidado no capitalismo financeiro globalizado}

Nancy Fraser (2016, p. 99) sugere que a crise do cuidado deve ser interpretada como a expressão das contradições do capitalismo financeirizado, que sistematicamente vem minando a reprodução social. Ela embasa sua afirmação em duas ideias: "as tensões atuais sobre cuidado não são acidentais, mas têm raízes sistêmicas profundas na estrutura de nossa ordem social"; a referida crise é indicativo de que há "algo podre não só na forma atual, financeirizada do capitalismo, mas na sociedade capitalista per se" (FRASER, 2016, p. 99).

Traçando um raciocínio semelhante ao das economistas feministas descrito no item 1.3, a autora argumenta que o sistema capitalista depende que atividades de reprodução social não remuneradas produzam e mantenham vínculos sociais, pois elas são necessárias para a existência de trabalho assalariado, assim como para a acumulação de mais-valia e para o funcionamento do capitalismo enquanto tal, uma vez que não poderiam existir sem trabalho doméstico, educação das crianças, cuidado afetivo e outras atividades que permitem a formação de novas gerações de trabalhadores e o reabastecimento das atuais (FRASER, 2016, p. 101-102). Por esse motivo, ao destruir suas próprias condições de manutenção, a dinâmica de acumulação de capital "come seu próprio rabo" (eats its own tail) (FRASER, 2016, p. 103).

Fraser (2016, p. 104) pormenoriza seu raciocínio, explicando que o capitalismo global e financeirizado moveu indústrias para regiões de baixos salários, recrutou mulheres para a força de trabalho remunerada e promoveu o desinvestimento nos Estados de bem-estar social, externalizando o trabalho de cuidado para famílias e comunidades, de modo que diminuiu sua capacidade de realizá-lo. O resultado foi "uma nova e dividida organização da reprodução social, comodificada para aqueles que podem pagar por ela e privatizada para aqueles que não podem", uma vez que "pessoas da segunda categoria fornecem cuidado em troca de salários (baixos) para pessoas da primeira" (FRASER, 2016, p. 112).

Segundo ela, o efeito disso é a intensificação da contradição inerente ao capitalismo entre produção econômica e reprodução social, institucionalizando essa divisão em uma base de gênero, ao mesmo tempo em que, ideologicamente, redefine 
emancipação em termos produtivos do mercado, enquanto a reprodução aparece como um obstáculo para o avanço do sistema (FRASER, 2016, p. 113-114). Essa concepção simboliza a atual forma de contradição social do capitalismo:

Além de diminuir os serviços públicos e recrutar mulheres para o trabalho assalariado, o capitalismo financeiro reduziu os salários reais, aumentando o número de horas de trabalho remunerado por casa necessário para sustentar uma família e provocando uma disputa desesperada para transferir trabalho de cuidado para outros. Para preencher o 'déficit de cuidado', o regime importa trabalhadoras migrantes de países pobres para ricos. (...) Mas, para fazer isso, os migrantes devem transferir suas próprias responsabilidades familiares e comunitárias para outros cuidadores ainda mais pobres, que devem, por sua vez, fazer o mesmo - e assim por diante, em cada vez mais longas 'cadeias globais de cuidado'. Longe de preencher o déficit de cuidados, o resultado concreto é de deslocá-lo - das famílias mais ricas para as mais pobres, do Norte para o Sul Global (FRASER, 2016, p. 114). ${ }^{38}$

Saskia Sassen (2003, p. 254) chega a conclusões muito semelhantes às de Fraser quando se propõe a analisar a globalização de forma diversa da narrativa dominante, a qual enfatiza que nos domínios da economia informatizada e da comunicação instantânea não é mais importante o lugar onde se produzem valores, mas apenas a existência de um profissional altamente qualificado para exercer sua função. A autora revela, entretanto, que quando mulheres do Sul migram para o Norte em busca de trabalho, tais como babás, trabalhadoras domésticas ou prostitutas, elas participam de dois conjuntos de configurações dinâmicas: a cidade global e os circuitos de sobrevivência que emergiram do aprofundamento da miséria em outras regiões do globo (SASSEN, 2003, p. 225).

Sassen (2003, p. 225) explica que as cidades globais concentram algumas das principais funções e recursos da economia global, com elevada demanda por profissionais altamente remunerados, ao mesmo tempo em que as empresas e o estilo de vida desses profissionais geram a demanda por trabalhadores de baixa remuneração. Por isso, as cidades globais atraem um grande número de mulheres e imigrantes, que são incorporados no mercado de trabalho seja como zeladores e reparadores nas empresas ou

\footnotetext{
${ }^{38}$ Excerto original: "As well as diminishing public provision and recruiting women into waged work, financialized capitalism has reduced real wages, thus raising the number of hours of paid work per household needed to support a family and prompting a desperate scramble to transfer carework to others. To fill the 'care gap', the regime imports migrant workers from poorer to richer countries. (...) Far from filling the care gap, the net effect is to displace it - from richer to poorer families, from the Global North to the Global South".
} 
como trabalhadoras domésticas, babás e atendentes de lojas e restaurantes que recebem os profissionais de alta renda (SASSEN, 2003, p. 225).

Enquanto isso, "como as economias do Terceiro Mundo na periferia do sistema global lutam contra a dívida e a pobreza, elas constroem circuitos de sobrevivência nas costas das mulheres", que enviam remessas para casa, o que transforma essas trabalhadoras, consideradas atores econômicos sem valor, em peças cruciais para construir e expandir economias (SASSEN, 2003, p. 256). Isso leva Sassen (2003, p. 260) a sentenciar que "sua invisibilidade impede que as mulheres imigrantes emerjam como o forte proletariado que seguiu das formas anteriores de organização econômica".

De modo semelhante, a já mencionada Arlie Hochschild, aclamada socióloga das emoções, com a extensa pesquisa sobre a divisão do trabalho e do tempo demandado por responsabilidades familiares ${ }^{39}$, ao tratar das cadeias globais de cuidado, propõe tirar de foco a "frente da cena" da globalização e do livre mercado, com seus elegantes homens de negócios em Wall Street ou no Vale do Silício, para olhar os bastidores, em que ela encontra trabalhadoras imigrantes, cuja atividade deixa de ser construir estradas ou erguer prédios, "para se tornar o trabalho emocional de cuidar das pessoas", no que se inclui “enfrentar as dilacerantes rupturas na sua relação com a própria família e consigo mesma".

Ao analisar tais fluxos, Hochschild (2003, p. 20) afirma que muitas das trabalhadoras que migram são direcionadas ao emprego doméstico, frente a um número cada vez maior de mulheres no mercado de trabalho em países desenvolvidos, mas cujas carreiras estão moldadas no padrão masculino, que exige delas dedicação de muitas horas ao trabalho remunerado. Do outro lado, as migrantes também sofrem com longas jornadas de trabalho, ao mesmo tempo em que deixam seus filhos com as avós ou outras parentes em seus países de origem, transplantando o afeto (global heart transplant) para a família a ser cuidada (HOCHSCHILD, 2003, p. 22).

Perante essa realidade, a autora constata a mesma lógica imperialista de extração de recursos do Terceiro Mundo para enriquecer o Primeiro Mundo, afirmando que o amor e o cuidado se tornam o "novo ouro", com a diferença de que a remoção desse recurso

\footnotetext{
${ }^{39}$ Em seu mais recente trabalho, a autora mudou o foco: ao invés de continuar pesquisas que demonstravam a necessidade de respostas do Estado, como as políticas voltadas ao cuidado, ela passou a querer entender as pessoas que reivindicavam o oposto, sua redução extrema. Nesse caminho, ela dedicou-se a compreender a direita estadunidense - em especial os apoiadores do Tea Party - e o sentimento de "estranhos em sua própria terra" que carregam (HOCHSCHILD, 2016).
} 
não é à força, como em tempos coloniais, mas feita por uma forma de coerção mais sutil, que é a pressão econômica, pois a desigualdade entre países pobres e ricos as empurra a buscar trabalho fora de seu país natal por falta de opção (HOCHSCHILD, 2003, p. 26). Desse modo, sua conclusão é a seguinte:

O baixo valor atribuído ao trabalho de cuidado não resulta da ausência de necessidade, nem da simplicidade ou facilidade de fazê-lo. Pelo contrário, o declínio do valor da assistência à infância resulta de uma política cultural de desigualdade. Isso pode ser comparado ao declínio do valor dos produtos alimentares básicos em relação aos manufaturados no mercado internacional. Embora claramente mais necessárias para a vida, as culturas como trigo e arroz obtêm preços baixos e em queda, enquanto os produtos manufaturados são mais valorizados. Assim como o preço de mercado dos produtos primários mantém o Terceiro Mundo abaixo na comunidade das nações, o baixo valor de mercado do cuidado mantém o status das mulheres que o fazem - e, em última análise, de todas as mulheres - baixo (HOCHSCHILD, 2003, p. 29, tradução nossa). ${ }^{40}$

Olhando o mesmo fenômeno com lentes da Economia Feminista, Nancy Folbre (2006, p. 190) fala nas significativas dimensões internacionais da economia do cuidado, registrando que o aumento do capital e mobilidade do trabalho reduziram as implicações econômicas das fronteias nacionais. As desigualdades regionais e a pressão econômica levam adultos, criados e educados em países pobres, a emigrarem para trabalhar em países ricos, fornecendo "uma fonte de capital humano livre", não sendo suficientes as remessas que esses trabalhadores enviam para seus países de origem para pagar os custos (FOLBRE, 2006, p. 190). Ao mesmo tempo, entra em jogo um "dreno de cuidado" (care drain),

(...) Já que muitas mulheres em países pobres deixam suas famílias para trabalhar como babás ou cuidadoras de idosos em países ricos. As imigrantes ganham acesso a empregos melhores, mas suas comunidades de origem perdem cuidadoras. Os países anfitriões desfrutam dos benefícios do atendimento relativamente barato que as imigrantes oferecem. Ao mesmo tempo, a disponibilidade de imigrantes reduz a pressão para fornecer maior financiamento público para os cuidados dependentes (FOLBRE, 2006, p. 190). ${ }^{41}$

\footnotetext{
${ }^{40}$ Excerto original: "The low value placed on caring work results neither from an absence of need for it nor from the simplicity or ease of doing it. Rather, the declining value of child care results from a cultural politics of inequality. It can be compared with the declining value of basic food crops relative to manufactures goods on the international market. Though clearly more necessary to life, crops such as wheat and rice fetch low and declining prices, while manufactured goods are more highly valued. Just as the market price of primary produce keeps the Third World low in the community of nations, so the low market value of care keeps the status of women who do it - and, ultimately, all women - low".

${ }^{41}$ Excerto original: "A 'care drain' also comes into play as many women in poor countries leave their
} 
Ampliando essa análise, Silvia Federici (2012, cap. 9) sustenta que a globalização se apresentou como um processo de acumulação primitiva, tendo assumido, no Norte, a forma de "desconcentração e realocação industrial, também de flexibilização e precarização do trabalho, e produção just in time", ao passo que no Sul observou-se a produção pela via das maquiladoras, liberalização das importações e privatização das terras. Independente da forma, o objetivo teria sido o mesmo:

Ao destruir as economias de subsistência, separando os produtores dos meios de subsistência e tornando os milhões dependentes dos rendimentos monetários, mesmo quando não conseguem aceder ao emprego assalariado, a classe capitalista relança o processo de acumulação e corta o custo da produção de mão-de-obra. Segundo, a desterritorialização do capital e a financeirização das atividades econômicas, que a 'revolução dos computadores' tornou possível, criaram as condições pelas quais a acumulação primitiva se tornou um processo permanente, através do movimento quase instantâneo de capital em todo o mundo, quebrando as restrições impostas ao capital pela resistência dos trabalhadores à exploração. Em terceiro lugar, assistimos ao desinvestimento sistemático do Estado na reprodução da força de trabalho, implementado por meio de programas de ajuste estrutural e do desmantelamento do 'Estado de Bem-Estar Social'. Em quarto lugar, a apropriação e destruição corporativa de florestas, oceanos, águas, pescarias, recifes de coral, espécies animais e vegetais atingiu um ápice histórico (FEDERICI, 2012, cap. 9). ${ }^{42}$

Esse desenvolvimento afetou toda a população do planeta, ainda que em níveis diferentes, por isso Federici (2012, cap. 9) entende que a nova ordem global seria melhor descrita como um processo de recolonização, tendo sido testemunhados os "mais radicais processos de expropriação e pauperização e o mais radical desinvestimento do Estado na reprodução da força de trabalho". Salários caíram a níveis baixíssimos, populações

families behind in order to work as child care or elder care workers in rich countries. Migrants gain access to better employment, but their communities of origin lose caregivers. Host countries enjoy the benefits of the relatively inexpensive care that migrants provide. At the same time, the availability of migrants reduces the pressure to provide greater public funding for dependent care".

${ }^{42}$ Excerto original: "By destroying subsistence economies, by separating producers from the means of subsistence and making millions dependent on monetary incomes, even when unable to access waged employment, the capitalist class has relaunched the accumulation process and cut the cost of laborproduction. Second, the de-territorialization of capital and financialization of economic activities, which the "computer revolution" has made possible, have created the conditions whereby primitive accumulation has become a permanent process, through the almost instantaneous movement of capital across the world, breaking over and over the constraints placed on capital by workers' resistance to exploitation. Third, we have witnessed the systematic disinvestment by the state in the reproduction of the workforce, implemented through structural adjustment programs and the dismantling of the 'welfare state'. Fourth, the corporate appropriation and destruction of forests, oceans, waters, fisheries, coral reefs, animal and vegetable species has reached an historic peak". 
inteiras foram desmonetizadas enquanto suas terras foram tomadas e "onde os programas de austeridade e a grilagem de terras não puderam chegar, a guerra completou a tarefa, abrindo novos terrenos para a perfuração de petróleo e a exploração de diamante ou columbita-tantalita” (FEDERICI, 2012, cap. 9).

Federici (2012, cap. 9) interpreta os atuais fluxos migratórios como um indicador da crise da reprodução da força de trabalho no mundo, não havendo dúvida para ela de que se milhões de pessoas saem de seus países para um destino incerto, encarando duras viagens e a perspectiva da morte, é porque elas não conseguem se manter em condições de vida minimamente adequadas. Segundo ela, isso fica evidente quando considera-se que metade dos migrantes são mulheres, justamente aquelas que normalmente ficam, "porque são aquelas que se sentem mais responsáveis pela reprodução de suas famílias"; logo, "quando centenas de milhares deixam suas casas para enfrentar anos de humilhação e isolamento (...), sabemos que algo bastante dramático está acontecendo na organização da reprodução mundial" (FEDERICI, 2012, cap. 9).

Nesse contexto, o trabalho de cuidado não foi reduzido graças à tecnologia, mas redistribuído "nos ombros de diferentes sujeitos por meio de sua comercialização e globalização", sujeitos esses que continuam sendo majoritariamente mulheres (FEDERICI, 2012, cap. 9). Foram as mulheres que absorveram o "choque da globalização econômica", precisando "compensar com seu trabalho a deterioração das condições econômicas produzidas pela liberalização da economia mundial e o crescente desinvestimento dos Estados na reprodução da força de trabalho", que se somou à expansão do trabalho em domicílio e ao crescimento do emprego feminino para reforçar a condição de vulnerabilidade social e econômica das mulheres perante o capital (FEDERICI, 2012, cap. 9).

Em termos políticos, a crise do cuidado revelou o cuidado - ou a falta dele como um problema público (DAMAMME; HIRATA; MOLINIER, 2017, p. 5), sendo, para os países desenvolvidos, reflexo da política neoliberal nos Estados de bem-estar social, que gradualmente reduziram suas políticas públicas de fornecimento de creches para crianças, instituições de acolhimento para idosos e refeitórios públicos. Já para os países pobres, que "exportam" trabalhadores do cuidado para países ricos e que nunca forneceram serviços de saúde pública suficientes, os problemas decorrentes da crise do cuidado tem relação com a transferência, para outras mulheres, do dever de cuidar das crianças daquelas que emigraram. 
De acordo com Rhacel Salazar Parreñas (2003, p. 41), em um artigo que trata da crise do cuidado nas Filipinas, decorrente do número expressivo de mulheres naquele país que emigram para serem babás e empregadas domésticas - e que constitui a maior fonte de entrada de moeda estrangeira do país -, o conflito entre necessidade econômica e papéis de gênero faz com que as migrantes sejam vistas como mães más, reforçando um ideal de família nuclear incompatível com a realidade. Ao fazê-lo, desvia o foco das obrigações do poder público em prover cuidado coletivo para as crianças de famílias transnacionais, bem como do dever dos pais em relação a seus filhas e filhos (PARREÑAS, 2003, p. 53).

Com relação ao envelhecimento da população no mundo, sem precedentes na história da humanidade - a expectativa de vida global cresceu mais nos últimos 50 anos que nos cinco mil anteriores -, seu impacto na redução da população economicamente ativa e no aumento do número de aposentados desgasta as instituições do Estado-nação que precisam lidar com essa nossa configuração social (NEILSON, 2017, p. 31). Essa realidade, somada à financeirização neoliberal, têm impulsionado governos a apresentar reformas nos regimes nacionais de aposentadoria, incentivando planos previdenciários privados, baseados nos mercados financeiros globais, exposição a risco que prejudica os aposentados (NEILSON, 2017, p. 52).

É falacioso, no entanto, pensar que as pessoas idosas são unicamente receptoras do cuidado, não obstante elas tem historicamente sido provedoras também, pois dentro das casas em que mulheres assumem postos no mercado de trabalho, são suas mães, sogras ou outras parentes mais velhas que substituem sua presença no cuidado das crianças e que se ocupam das tarefas domésticas, permitindo que as mulheres mais jovens dediquem-se às atividades remuneradas (CARRASCO; BORDERÍAS; TORNS, 2011, p. 28).

Ademais, a crise do cuidado envolve também a imbricação entre esfera privada e mercantilização das emoções, própria do atual sistema econômico, em que se verifica a transformação do modo de expressar preocupação com o próximo por influência do mercado, bem como a segmentação das atividades de serviços às pessoas (MOLINIER; PAPERMAN, 2015, p. 52). A fim de ilustrar essa realidade, Pascale Molinier e Patricia Paperman $(2015$, p. 52) mencionam a profissão de passeador de cachorros, surgida da vontade das pessoas de terem cães, apesar de não terem tempo para cuidar deles - o que vale também para filhos, que vai desde a terceirização da recreação nas festas de 
aniversário até a possibilidade de se comprar um bebê "pronto" de uma barriga de aluguel.

Atualmente, por não produzirmos nossos próprios bens e sermos dependentes do dinheiro, há uma dependência mútua dos trabalhos e uma relação dinâmica entre o processo de produção e reprodução de mercadorias e o processo de reprodução da população, em especial da força de trabalho (CARRASCO, 2013 p. 45-46). Nas palavras de Cristina Carrasco (2013, p. 53), a crise econômica da atualidade tem gerado "uma redistribuição selvagem da renda e da riqueza e também dos tempos e trabalhos", que desencadeou um processo de reprivatização da reprodução social, com drástica redução dos gastos públicos em serviços de cuidado, educação e saúde, com o consequente aumento do trabalho que recai sobre as mulheres, incrementado com a redução da renda das famílias, sobretudo por conta do desemprego. Vê-se, portanto, que "o trabalho doméstico e de cuidados funciona como um amortecedor contra os efeitos devastadores da crise no bem-estar das pessoas" (CARRASCO, 2013, p. 53). ${ }^{43}$

A ideia promovida pela atual sociedade, profundamente desigual, é a de que o estilo de vida que devemos aspirar é daqueles que possuem mais dinheiro e mais bens de consumo, ainda que na prática isso também signifique um estilo de vida em que as atividades de cuidado e autocuidado fiquem relegadas frente às exigências contrapostas do tempo de trabalho e consumo (HIMMELWEIT, 1995, p. 10). O "problema" das necessidades que estão fora do padrão de consumo é que elas caem na invisibilidade e que elas são privadas e não possuem preço (HIMMELWEIT, 1995, p. 10).

No raciocínio de Susan Himmelweit (1995, p. 10), a exacerbação do tempo que se transforma em dinheiro faz com que ele seja contabilizado de forma a excluir aspectos não quantificáveis da vida, como o cuidado emocional e o apoio. Uma das consequências disso é que embora praticamente todos se sintam com pouco tempo e pouco dinheiro, os lares de quase todas as camadas sociais - com exceção dos mais ricos - buscam melhorar sua situação trocando ainda mais tempo por dinheiro (HIMMELWEIT, 1995, p. 12).

\footnotetext{
${ }^{43}$ Para enxergar a magnitude do problema, Cristina Carrasco, durante a entrevista concedida à Fabiana Grecco e a mim na cidade de Barcelona, em junho de 2017, fez a seguinte pergunta: "O que aconteceria se proibissem a contratação de pessoas para o trabalho doméstico?" Ela conjecturou que haveria conflito entre homens e mulheres, conflito com o Estado, conflito com os empregadores por conta dos tempos e jornadas de trabalho, entre outros. Ademais, ela completou, para as classes média e alta seria um grande problema, mas para pessoas pobres não se passaria nada, além de que o peso para países desenvolvidos, que dependem das cadeias globais de cuidado, também seria imenso - vide a Europa, que não consegue garantir a reprodução social sem o trabalho de mulheres imigrantes (CARRASCO, 2017).
} 
Verifica-se, assim, que a crescente mercantilização das necessidades reduziu a importância relativa daquelas que não adotam a forma de consumo, processo que tem sido alimentado pela desigualdade entre os lares - tanto na construção das referidas necessidades quando na possibilidade de contratar pessoal para atendê-las (HIMMELWEIT, 1995, p 13). A relação é simbiótica: “a comoditização das necessidades de consumo e a diminuição da importância de todas as outras necessidades" reforçaram a desigualdade "à medida que o dinheiro se torna o único meio desigualmente distribuído para todos os fins" (HIMMELWEIT, 1995, p 13).

\subsubsection{Crise do cuidado no Norte e no Sul}

A crise do cuidado descrita pela maioria das pesquisadoras voltadas ao tema tem como foco a realidade vivida pelos países do Norte, o que fica bastante claro em sua descrição. Nesse sentido, a narrativa da emergência de um déficit de cuidado, no sentido de que o número de pessoas que precisam de cuidado, entre idosos, pessoas portadoras de deficiência e outros dependentes, por exemplo, cresceu nas últimas décadas, enquanto a oferta de cuidado diminuiu, é válida para retratar os efeitos da referida crise em países desenvolvidos (GLENN, 2012, p. 183).

No caso dos Estados Unidos, Evelyn Nakano Glenn (2010, p. 183) descreve como resultado do déficit de cuidado o fato de que as pessoas mais vulneráveis não recebem a quantidade e qualidade do cuidado de que precisariam, os membros da família e amigos se sobrecarregam com essas responsabilidades e sacrificam sua própria saúde para fornecer cuidado a suas entes, bem como as cuidadoras remuneradas, em sua maioria negras e imigrantes, trabalham por baixos salários e sem proteção social e benefícios que garantam sua própria dignidade na velhice.

Quanto às sociedades europeias, as pressões decorrentes da crise do cuidado variam de acordo com os modelos de Estado de Bem-Estar Social, uma vez que cada modelo incorporou o cuidado de maneira diferente (DALY; LEWIS, 2000, p. 288). O modelo de prestação de serviços públicos de cuidado era a oferta abundante com organização local, porém tem migrado para a individualização e familiarização - como acontece no caso da assistência oferecida a pessoas dependentes, cuja tendência tem sido transformar-se no pagamento direto à pessoa que necessita de cuidados, para que ela 
contrate uma cuidadora particular -, distanciando os Estados da responsabilidade (DALY; LEWIS, 2000, p. 294).

No entanto, essa é a realidade no Norte, sendo fundamental para a presente tese olhar para a realidade do Sul, em especial a brasileira. Nesse sentido, Amaia Pérez Orozco (2014, p. 171-173) vê a crise do cuidado como multidimensional, tendo impactado o Sul global há mais tempo, desde a imposição de severas medidas neoliberais que derivaram uma crise da reprodução social, na qual o sustento da vida tanto na dimensão material quanto emocional torna-se incerto ou impossível. Com o caos financeiro de 2007-2008, consolidaram-se em vários países do Norte global políticas de austeridade, com "socialização dos riscos do processo de acumulação do capital mediante a reprivatização dos riscos do processo de sustentabilidade da vida”, surgindo assim uma crise da reprodução social no Norte, similar à vivida pelo Sul, e caracterizada pelo agravamento das situações de precariedade.

Há semelhanças compartilhadas em quase todos os países do globo, como aponta Silvia Federici (2012, cap. 10) ao descrever que quanto mais as mulheres dedicam-se a cuidar dos outros, menos cuidado elas recebem em troca, pois o trabalho de cuidado não remunerado não é contabilizado nos sistemas de previdência e o mesmo, porém remunerado, é tratado como uma 'subclasse' à qual são conferidos menos direitos, o que faz com que "em quase todos os lugares do mundo as mulheres encaram a velhice com menos recursos que os homens, mensurados em termos de suporte familiar e recursos monetários". 44

No caso do Brasil, o cuidado é assumido predominantemente por redes de solidariedade, sejam elas familiares ou comunitárias, sendo este uma responsabilidade de membros da família, em especial das mulheres, e também das trabalhadoras domésticas e cuidadoras em domicílio (GUIMARÃES; HIRATA; SUGITA, 2012, p. 90). Pelo ângulo das despesas familiares, a contratação de trabalhadoras domésticas é regra geral para as classes médias e altas, seja com mensalistas ou diaristas ou babás, o que gera como contrapartida a existência de um amplo contingente de trabalhadoras em condições de

\footnotetext{
${ }^{44}$ Dentro desse raciocínio, Federici (2012, cap. 10) faz a dura afirmação de que os asilos para pessoas de baixa renda (low-income nursing homes) são os campos de concentração do nosso tempo. Concordando ou não com a comparação, fato é que no Brasil a situação das Instituições de Longa Permanência para Idosos está longe do ideal de cuidado e socialização dessas pessoas, além de atender apenas $1 \%$ da população idosa no país (cf. CAMARANO, 2010) e oferecer condições precárias de trabalho para suas empregadas (cf. GUIMARÃES; HIRATA; SUGITA, 2012).
} 
trabalho precárias, o que implica a imbricação de relações de poder que precisam ser consideradas (SORJ; FONTES, 2012, p. 110).

Diferente da Europa ou da América do Norte, as atividades de cuidado remuneradas aqui são realizadas predominantemente por brasileiras, não por imigrantes. Segundo Hirata (2011a, p. 88), o perfil das trabalhadoras remuneradas do cuidado é o seguinte: “[n]os países em que há migração estrangeira, são as migrantes estrangeiras; nos países onde não há migração estrangeira, são as migrantes internas, como é o caso do Brasil"'.

Nadya Guimarães, Helena Hirata e Kurumi Sugita (2012, p. 86) narram que “ainda que o trabalho doméstico tenha sido assumido, até o fim do século XIX, por escravos africanos e seus descendentes" e que grandes fluxos de migrantes europeus e japoneses tenham chegado ao país, no início do século XX, para o trabalho industrial e agrícola, "o setor de emprego doméstico remunerado nutre-se hoje de assalariados de nacionalidade brasileira, muitas vezes originários do Nordeste, mas também de Minas Gerais, do Paraná ou de Santa Catarina”, ou seja, de migrantes internos. ${ }^{45}$

Também o mercado e o Estado são prestadores de cuidado no Brasil, ainda que em menores proporções. No caso do mercado, verifica-se a existência de empresas de home care, por exemplo, enquanto, no âmbito estatal, há grande dificuldade de estruturar programas eficazes e bem sustentados (GUIMARÃES; HIRATA; SUGITA, 2012, p. 96). A efetivação do direito à creche, como será visto em capítulo posterior, está longe de ser uma realidade; também a estruturação de políticas públicas para idosos e pessoas com deficiência mostra-se uma grande dificuldade. ${ }^{46}$

Com relação à população idosa, Guita Grin Debert (2016, p. 248) explica que da “representação do avanço da idade como um processo contínuo de perdas - em que os

\footnotetext{
${ }^{45}$ A melhor compreensão das relações imbricadas às migrações internas para o cuidado no Brasil talvez possa começar nas formulações de Francisco de Oliveira $(1972 ; 2003)$ sobre a especificidade da forma brasileira de subdesenvolvimento, na qual é funcional a manutenção das desigualdades regionais e a convivência entre o crescimento industrial e a manutenção do padrão 'primitivo' das atividades agropecuárias. Para aprofundamento a respeito das desigualdades regionais no país, cf. também: BERCOVICI, 2003.

${ }^{46}$ Ainda assim, algumas iniciativas interessantes, mesmo que limitadas, surgiram desde o final dos anos 1990, como os Agente Comunitários de Saúde e os Agentes de Proteção Social, integrados ao Programa Saúde da Família (GUIMARÃES; HIRATA; SUGITA, 2012, p. 90). Infelizmente, porém, o atual governo tem tentado reformular o Programa Nacional de Atenção Básica, com a redução da cobertura do Programa de Agentes Comunitárias da Saúde e novas regras para a atividade, o que se soma ao cenário de congelamento de gastos públicos devido à EC 95/2016, que afetarão a atenção básica e a saúde da família (OBSERVATÓRIO DE ANÁLISE POLÍTICA EM SAÚDE, 2018).
} 
indivíduos ficam relegados a uma situação de abandono, de desprezo e de ausência de papéis sociais" decorre do "processo de constituição da velhice como uma preocupação social e política", servindo de fundamento para a gerontologia e para a legitimação de direitos como a aposentadoria e as leis protetivas aos idosos. No caso do Brasil, ainda que o sistema de seguridade social da Constituição de 1988 e o Estatuto do Idoso prevejam um sistema integrado de proteção a esse setor considerado vulnerável, há "desigualdade social persistente no acesso aos direitos da cidadania” (DEBERT, 2016, p. 249).

Isso se soma à construção da imagem da "terceira-idade bem-sucedida", como uma etapa gratificante da vida, que transformou a "velhice" em um problema de indivíduos negligentes que não souberam adotar estilos de vida adequados, criando uma "cortina de fumaça" para as situações de dependência e perda de autonomia de etapas mais avançadas do envelhecimento (DEBERT, 2012, p. 218). Isso se reflete na dificuldade de provisão de políticas públicas adequadas a esses setores -, pois asilos públicos e conjuntos para idosos são oferecidos em número diminuto e, normalmente, funcionam em condições precárias -, o que leva a responsabilidade pela velhice avançada a recair sobre as famílias ${ }^{47}$ e, consequentemente, as mulheres (DEBERT, 2016, p. 252). Diante dessa realidade, a autora afirma:

O prolongamento da vida humana é um ganho coletivo, mas tem se transformado em uma ameaça à reprodução da vida social e um risco para o futuro da sociedade. As projeções sobre os custos da aposentadoria e da cobertura médica e assistencial do idoso são apresentados como um problema nacional, indicador da invisibilidade de um sistema que em um futuro próximo não poderá arcar com os gastos de atendimento. Nas situações em que o desemprego e o subemprego atingem contingentes cada vez maiores da população mais jovem, os custos implicados na velhice, especialmente aqueles envolvidos nas fases mas avançadas da vida, crescem na mesma proporção dos avanços tecnológicos postos em ação para prolongar a vida humana (DEBERT, 2016, p. 253).

Guita Grinn Debert (2016, p. 255) critica, então, a visão limitada dos ditos “experts” em contabilidade pública que só fazem sugerir diminuição de gastos públicos, redução dos vencimentos e aumento da idade das aposentadorias como soluções para garantir a viabilidade do sistema. Acusar a inviabilidade do sistema de financiamento dos

\footnotetext{
${ }^{47}$ A perversidade de a responsabilidade pelo cuidado dos idosos recair sobre as famílias, reflexo das ambiguidades e dificuldades dessas relações normalmente sem amparo material ou psicológico, é exemplificada por Guita Debert (2012, p. 217), que aponta a contradição entre a ideia gerontológica de que "é desejo universal dos velhos serem cuidados pela família" e os altos índices de violência registrados nas Delegacias de Proteção ao Idoso serem de familiares.
} 
custos da idade avançada e transformar os problemas da velhice em responsabilidade individual são ações que recusam a solidariedade entre gerações (DEBERT, 2016, p. 255), além de acelerarem o disparo de uma bomba-relógio anunciada de abandono e desemparo de contingentes assustadores de seres humanos na velhice. ${ }^{48}$

Ademais, Debert (2012, p. 218) chama atenção para o fato de que tratar a questão do cuidado dos idosos como um problema da família ou das contas públicas previdenciárias implica na objetificação dessas pessoas, como se elas deixassem de ter vida pública ou deixassem de ser sujeitos de direito em decorrência da velhice. Ela complementa, afirmando que "apostar que o bem-estar na velhice está na reclusão do lar e que a família terá o auxílio do Estado para contratar o empregado doméstico nacional ou imigrante é adiar inconsequentemente a reflexão e as propostas" que contribuam para uma experiência de envelhecimento digna (DEBERT, 2012, p. 231).

Por fim, fazendo uma ponte com o texto de Hochschild (2003) sobre a extração de amor e o cuidado do Sul para o Norte ser equiparável à extração do ouro em tempos coloniais, a mesma comparação entre o trabalho exercido nesse dois períodos não é tão simples como se pode imaginar. Nesse sentido, Guita Debert e Mariana Pulhez (2017, p. 15) alertam que "falar de práticas escravocratas é destituir os cuidadores da capacidade de agenciamento e obscurecer o fato de que para muitas mulheres os circuitos do cuidado (...) são as únicas agências disponíveis". Este tema será melhor desenvolvido no Capítulo 3 desta tese.

Com isso encerro o presente capítulo, ao longo do qual foi possível constatar que o "cuidado está relacionado com questões de cidadania, do direito de cuidar e ser cuidado" e localiza-se na intersecção entre dicotomias como público/privado, informal/formal, trabalho remunerado/não remunerado (DEBERT; PULHEZ, 2017, p. 7). Além disso, o trabalho de cuidado tem grandes implicações no bem-estar humano e, diante das mudanças sociais que foram abordadas, não há mais possibilidade de continuar

\footnotetext{
${ }^{48}$ Não é difícil ver sinais desses cavaleiros do apocalipse se aproximando, como ocorre no Japão, em que os gastos encolhidos do governo com a previdência geraram um aumento no número de idosos que cometem crimes para conseguirem reclusão em penitenciárias que oferecem comida, acomodações e serviços de saúde gratuitos (SASAKI, 2016). No Brasil, o projeto de reforma da previdência defendido pelo governo Temer (PEC 287/2016), a reforma trabalhista e outros processos de retirada de investimento público condenam a sociedade "às incertezas do mercado em todas as dimensões da vida social", o que fará que o país perca gerações, presentes e futuras, "que não terão nem condições de disputar a xepa da feira para sua sobrevivência imediata, enquanto poucos reinarão no mundo da ostentação vazia" (COHN, 2017). Para nota técnica sobre a PEC 287/2016, cf.: DIEESE, 2017; para abordagens críticas da mesma, cf.: LAVINAS, 2017; BATISTA, 2017.
} 
tratando-o como "naturalmente" abundante, tampouco de subestimá-lo enquanto área de estudo (FOLBRE; NELSON, 2000, p. 122).

As perspectivas feministas apresentadas convergem no diagnóstico e nas conclusões a respeito da relação entre trabalho, gênero e cuidado, demonstrando, cada uma com seu enfoque, que a desvalorização do cuidado é parte de um programa sistêmico de exploração do trabalho e opressão de gênero, sustentada por modelos ideais que valorizam o individualismo ao cuidado, o masculino ao feminino, a capacidade à vulnerabilidade. O próximo capítulo apresenta o esforço de reconstruir os fundamentos do Direito do Trabalho a partir da base teórica aqui delineada, dando enfoque à Teoria Feminista do Direito do Trabalho e traçando críticas a algumas das noções basilares da disciplina, como trabalho, tempo e remuneração. 


\section{CAPÍTULO 2 \\ FORMAÇÃO SEXISTA DO DIREITO DO TRABALHO}

O embasamento teórico do Capítulo 1 permitiu a percepção de que a forma como a sociedade organiza o cuidado pode favorecer ou dificultar a igualdade de gênero (SORJ; FONTES, 2012, p. 103), além de revelar o esforço comum das vertentes feministas apresentadas de ampliar e reinterpretar categorias de discursos teóricos que predominam na cultura ocidental, de maneira a tirar da invisibilidade as atividades socialmente designadas às mulheres. Sem sombra de dúvida, como diria Sandra Harding (1993, p. 8), "não foram propriamente as experiências das mulheres que fundamentaram qualquer das teorias a que recorremos", o que se desdobra na percepção de que categoriais mais fundamentais do pensamento social e econômico sofrem desvios sexistas, racistas, colonialistas, capacitistas.

Diante disso, permito-me passar para a discussão do cuidado no campo do Direito, a fim de utilizar a perspectiva feminista para desafiar os paradigmas sobre os quais o Direito do Trabalho fundou-se, que transplantam para o raciocínio juslaboralista uma série de estereótipos de gênero. O reflexo mais visível da desvalorização do trabalho de cuidado é sua histórica exclusão das normas de proteção ao trabalho, em especial quando se trata de trabalho de cuidado não remunerado, ou uma incidência reduzida e um tratamento específico, como acontece com a legislação acerca do emprego doméstico.

O papel da crítica feminista ao Direito é reconstruí-lo de modo que não sirva de base, tampouco reforce a dominação dos homens sobre as mulheres (MATTAR, 2001, p. 78). Assim, consoante Clare Dalton (1987, p. 2), envolver-se no pensamento jurídico feminista é relacionar investigações e atividades ligadas ao Direito a partir dessa perspectiva, de modo a comprometer-se com três tarefas: i) descrever a subordinação das mulheres, explorando sua natureza e extensão; ii) perguntar como - por meio de quais mecanismos - e porquê - por quais motivos - as mulheres continuam a ocupar esta posição e; iii) dedicar-se à promover uma mudança efetiva nesse campo de estudo.

Tomadas essas considerações, o percurso deste capítulo tem início na apresentação da área da Teoria Feminista do Direito do Trabalho, amplamente desenvolvida nos países anglófonos, mas que ainda é pouco conhecida no Brasil. Em seguida, as reflexões iniciadas por essa vertente teórica serão aplicadas às bases teóricas e 
categoriais fundamentais do Direito do Trabalho, com o intuito de revisitar a noção jurídica de "trabalho", o programa do trabalhador universal, o conceito de tempo e às formas de mensurá-lo, bem como os moldes usados para definir produtividade e fixar a remuneração e, por meio disso, promover a uma análise crítica. Isso será feito com a atenção voltada ao ordenamento jurídico-trabalhista nacional, ainda que o pano de fundo seja o Direito do Trabalho em uma perspectiva internacional.

\subsection{INTRODUÇÃO À TEORIA FEMINISTA DO DIREITO DO TRABALHO}

Meu ponto de partida e maior referência da Teoria Feminista do Direito do Trabalho é Judy Fudge ${ }^{49}$, cuja obra coloca como pressuposto central as contribuições teóricas feministas que estendem o conceito de trabalho além do trabalho remunerado, isto é, incluindo trabalho de cuidado não remunerado, em associação a uma perspectiva mais ampla da lei, reconhecida em seus aspectos normativos e institucionais, sua dimensão discursiva e suas relações dinâmicas e contraditórias com as atrizes e atores sociais (FUDGE, 2016, p. 10).

Segundo a autora, "as instituições jurídicas e as normas legais não refletem simplesmente as diferenças naturais entre os sexos, mas, na verdade, estão profundamente envolvidas em designar gênero para diferentes formas de trabalho", na medida em que a separação consignada no ordenamento jurídico entre trabalho remunerado e não remunerado ajudou a moldar a "participação das mulheres na força de trabalho e os tipos de arranjos empregatícios para os quais elas são relegadas, bem como o valor atribuído a esses diferentes tipos de trabalho" (FUDGE, 2016, p. 10). Dessa forma, as instituições jurídicas foram construídas ao mesmo tempo que promoveram "arranjos de trabalho e normas profundamente marcadas pelo gênero", como é o caso do contrato de trabalho (FUDGE, 2016, p. 11).

A maior aspiração das teóricas feministas do Direito do Trabalho é ajudar a revitalizar a área de estudos jurídico-trabalhista a partir da inserção de conceitos-chave para o feminismo "como trabalho, cuidado, gênero e reprodução social" (FUDGE; GRABHAM, 2014, p. 1). Além disso, as abordagens feministas vão além de uma disputa

\footnotetext{
${ }^{49}$ Leitura recomendada pelo Prof. Pedro Augusto Gravatá Nicoli, na banca de qualificação desta tese.
} 
demarcatória sobre as fronteiras da disciplina, questionando "o próprio ato de delinear diferentes jurisdições legais"; questionam, por exemplo, o motivo pelo qual o trabalho doméstico não remunerado é atribuído ao Direito de Família, ou a prostituição ao Direito Penal (FUDGE; GRABHAM, 2014, p. 2). Logo, importa saber quem são as pessoas protegidas pelo Direito do Trabalho, quais os locais e territórios por ele cobertos e, ainda, quem são os "trabalhadores" para quem a lei trabalhista foi criada (FUDGE, 2014, p. 2).

Um dos esforços centrais que permitiu o desenvolvimento dessa vertente teórica foi a demonstração de que a "jurisdição do Direito do Trabalho é histórica e contingente, não conceitual e universal", o que Judy Fudge (2014, p. 1), por exemplo, ilustra por meio do argumento de que o cuidado não remunerado e o trabalho doméstico realizado no interior dos domicílios perturbam o escopo pessoal da disciplina juslaboralista. Nas palavras da autora,

\begin{abstract}
Nossa concepção atual do Direito do Trabalho baseia-se em instituições e normas jurídicas que historicamente constituíram, e atualmente reforçam, uma série de dicotomias entre trabalho público e privado e trabalho assalariado e não remunerado, as quais sistematicamente desfavorecem as pessoas que se dedicam ao cuidado e ao trabalho doméstico e reforçam os papéis tradicionais de gênero. Ao pedir que o campo do Direito do Trabalho seja expandido para abranger a regulação de todos os dilemas recorrentes dos mercados de trabalho capitalistas e que seu objetivo normativo seja o de alcançar a igualdade democrática, estou adotando o projeto utópico de construir novos imaginários sociais. Muito do conhecimento sobre Direito do Trabalho é nostálgico do passado (FUDGE, 2016, p. 25-26, tradução nossa). ${ }^{50}$
\end{abstract}

De acordo com Joanne Conaghan (2014, p. 2), considerando a relevância da divisão sexual do trabalho para a organização social, seria de se prever que o gênero fosse considerado um fator de importância na teorização do Direito do Trabalho. No entanto, a realidade é que, com exceção dos estudos feministas na área, o gênero enquanto categoria de valor analítico é praticamente ausente na teoria juslaboralista, não desempenhando "nenhum papel (formal) na constituição e mapeamento da disciplina" e não aportando "nenhuma contribuição conceitual (reconhecida) para o quadro analítico central" (CONAGHAN, 2014, p. 3). Assim, ainda que o gênero seja "parte da realidade empírica

\footnotetext{
${ }^{50}$ Excerto original: "Our current conception of labour law is built upon legal institutions and norms that historically constituted and presently reinforce a series of dichotomies between public and private and waged and unwaged work that systematically disadvantage those who engage in care and domestic work and reinforce traditional gender roles. By calling for the field of labour law to be expanded to encompass the regulation of all of the recurring dilemmas of capitalist labour markets and its normative goal to be the achievement of democratic equality, I am embracing the utopian project of constructing new social imaginaries. Too much of labour law scholarship is nostalgic for the past".
} 
sobre a qual o Direito do Trabalho atua, mas não é uma parte definidora ou determinante" (CONAGHAN, 2014, p. 3).

Ora, é evidente que há uma série de normas voltadas especificamente às mulheres no ordenamento jurídico-trabalhista que vão desde a proteção à maternidade, até regras de não-discriminação de gênero e que tratam de evitar abusos sexistas, mas elas não mudam a realidade de que a teoria do Direito do Trabalho leva o gênero em consideração apenas em normas específicas; assim, a perspectiva de gênero não é transversal ao Direito do Trabalho, ficando isolada à temática das "mulheres" ou da "sexualidade", o que gera distorções sexistas em suas categorias fundamentais. Nesse sentido, consoante Fudge (1996, p. 239), o enfoque do Direito do Trabalho "sobre as características sexuais e reprodutivas das mulheres obscurece como a subordinação das mulheres é reproduzida e trata os homens como o padrão contra o qual as mulheres são julgadas".

A abordagem tradicional sobre a posição desigual das mulheres no mercado de trabalho, a partir dos anos 1970, permitiu que a legislação migrasse de um padrão de "proteção ao trabalho da mulher" que mostrava-se claramente sexista para uma tentativa de elaboração de dispositivos legais para amenizar a discriminação de gênero escancarada e cuidar de questões supostamente específicas, como a maternidade. ${ }^{51}$ Para Fudge (1996, p. 239), ao enfocar os "atributos distintivos das trabalhadoras, a legislação foi concebida para responder às diferentes necessidades das mulheres ou para neutralizar essas diferenças", sem conseguir superar seu caráter de gênero, perpetuando a estrutura hierárquica do mercado de trabalho.

A pretensão é deixar evidente que a perspectiva de gênero no Direito do Trabalho não se restringe à temática "das mulheres" ${ }^{\text {, }}$, pelo contrário, diz respeito a afastar o padrão normativo masculino que se pretende universal. Essa segregação fica evidente em manuais da disciplina, que tratam de questões como discriminação e responsabilidades familiares em tópicos especificamente voltados ao "Trabalho da

\footnotetext{
${ }^{51}$ Esse caminho no Direito do Trabalho brasileiro foi traçado em minha dissertação de mestrado, no qual abordo, por exemplo, a gradativa retirada das proibições ao trabalho feminino noturno, em subsolo e em atividades insalubres, a revogação de artigos visivelmente patriarcais da CLT em decorrência da promulgação da Constituição de 1988 e a mudança do paradigma da proteção para a promoção do trabalho feminino, do que derivam leis como a 9.799/1999, que proíbe a discriminação na contratação e a revista íntima. Cf. VIEIRA, 2014.

${ }^{52}$ A crítica se aplica, inclusive, aos juristas progressistas, que têm extrema dificuldade de entender que a crítica feminista do Direito é crítica do Direito, não um assunto apartado de interesse "das mulheres".
} 
Mulher", como se não fosse relevante para o mercado de trabalho "como um todo". Claro que pode-se alegar que eles seguem as divisões da CLT, mas independente disso, as questões de gênero - e de raça, e de sexualidade - deveriam ser tratadas de forma transversal.

Assim, mais do que assegurar normas jurídicas mais igualitárias entre os sexos sem deixar de reconhecer a importância dessas conquistas -, as teóricas feministas do Direito do Trabalho argumentam pela necessidade de se prestar atenção nos aspectos de gênero da organização social do trabalho, pois sem essa percepção o "campo de trabalho acadêmico não pode ser apropriadamente apreendido ou interrogado, nossos valores e objetivos não podem ser adequadamente perseguidos ou satisfatoriamente realizados" (CONAGHAN, 2014, p. 15).

Joanne Conaghan (2005, p. 26) chama a atenção para a separação entre trabalho e família forjada pelo Direito, retomando a interpretação de que Direito de Família e Direito do Trabalho seriam disciplinas separadas, o que deriva da "narrativa oficial" de que trabalho e família são esferas que operavam de forma autônoma e só recentemente convergiram por conta do aumento da participação das mulheres no mercado de trabalho. ${ }^{53} \mathrm{O}$ discurso juslaboralista é influenciado pela visão da relação apartada entre trabalho e família, refletindo-se nos arranjos de trabalho e nas leis que os regulavam, que tomaram como base a ideia de que os trabalhadores deveriam estar exclusivamente disponíveis aos empregadores durante a jornada de trabalho, numa relação que seria de longo prazo (CONAGHAN, 2005, p. 27-28). Ou seja, não se cogitava que "os trabalhadores" tivessem responsabilidades familiares.

Todavia, como destaca Conaghan (2005, p. 28), por trás da narrativa oficial, há uma história não oficial de interdependência, sendo a separação entre trabalho família produto de uma maneira particular de organização do trabalho, reforçado por mecanismos e instituições como a lei, que ofuscam a relação funcional entre essas esferas. Logo, a divisão trabalho/família sobre a qual repousa o Direito do Trabalho tem um viés de gênero, pois a alocação do trabalho de cuidado para a família foi o mecanismo-chave que permitiu que os trabalhadores, homens, se engajassem no trabalho remunerado de forma

\footnotetext{
${ }^{53}$ Para uma narrativa pormenorizada sobre as mudanças históricas nos regimes de reprodução social na organização capitalista, que delimitam as "lutas de fronteiras" entre o que é da alçada da família ou do mercado, cf.: FRASER, 2016.
} 
exclusiva e sem restrições de tempo (CONAGHAN, 2005, p. 29). Assim, nas palavras da autora:

\begin{abstract}
Adotar uma perspectiva feminista é, antes de mais nada, trazer uma percepção de gênero sobre os arranjos sociais e econômicos para enfrentar entendimentos de 'gênero neutro'. Ao destacar as suposições profundamente marcadas pelo gênero (embora em grande parte desarticuladas) que permeiam e informam o Direito do Trabalho, o feminismo contribui para uma melhor compreensão tanto do seu conteúdo quanto de suas implicações para as mulheres trabalhadoras. Ao mesmo tempo, o feminismo está preocupado não apenas em garantir que os aspectos de gênero do Direito do Trabalho sejam plenamente reconhecidos e articulados, mas também em explorar como sua submersão contribui para a construção e manutenção de arranjos prejudiciais às mulheres (CONAGHAN, 1999, p. 18, tradução nossa). ${ }^{54}$
\end{abstract}

Busca-se, portanto, um molde de ordenamento juslaboralista que na prática, não apenas na retórica, seja amigável às pessoas que assumem o trabalho de cuidado, particularmente as mulheres (WILLIAMS, 2005, p. 213). Dessa forma, as contribuições teóricas das pesquisadoras feministas do Direito do Trabalho envolvem o questionamento sobre como "trabalho" e "mercado de trabalho" são concebidos normativamente e ampliam as fronteiras do campo para além do trabalho remunerado, evoluindo de uma abordagem instrumental para uma abordagem conceitual das dimensões do Direito e das relações sociais que o permeiam (FUDGE, 2014, p. 2).

Esse é o passo da Teoria Feminista do Direito do Trabalho que interessa a esta tese, que é de migrar de uma abordagem de gênero que questiona acerca da igualdade ou desigualdade pontualmente identificável na legislação para uma interpelação profunda das categorias, conceitos e fundamentos que regem toda a disciplina. Evidentemente, não pretendo negar a importância da dimensão normativa das análises feministas do Direito do Trabalho, que inclusive abriram espaço para o que se apresenta aqui, mas alinho-me à esperança de Judy Fudge (2014, p. 2) de que "uma maior atenção às contribuições conceituais dos estudos feministas" pode permitir revitalizar e dar forças a uma disciplina que tem sofrido sucessivos ataques.

\footnotetext{
${ }^{54}$ Excerto original: "To adopt a feminist perspective is, first and foremost, to bring a gendered perception of social and economic arrangements to bear upon otherwise 'gender neutral' understandings. By highlighting the deeply gendered (albeit largely unarticulated) assumptions which pervade and inform labour law, feminism contributes to a better understanding both of the content of labour law and of its implications for women workers. At the same time, feminism is concerned not just with ensuring that the gendered aspects of labour law are fully recognised and articulated but, also, with exploring how their submergence contributes to the construction and maintenance of arrangements detrimental to women".
} 
Essas reflexões levam à busca dos modos de regular o trabalho, o que vai além de somente ampliar o escopo da legislação trabalhista para incluir o cuidado não remunerado. Em outras palavras, é preciso “desenvolver um novo imaginário do Direito do Trabalho que se baseie numa caracterização mais inclusiva dos processos e instituições sociais que constituem um mercado de trabalho" (FUDGE, 2016, p. 11). Dentro dessa nova lógica, não seria mais possível, por exemplo, que empregadores concebessem “empregos com base no pressuposto de que é de responsabilidade individual e particular do trabalhador adaptar suas responsabilidades de cuidado aos requisitos temporais do trabalho" (FUDGE, 2016, p. 24).

Assim, essas poucas linhas fazem pensar que o Direito do Trabalho deve ser capaz de garantir dignidade e valorização dos cuidados sem levar em consideração os modelos inicialmente forjados para explorar e oprimir as mulheres, superando dicotomias que historicamente servem ao status quo. Nos próximos itens, buscarei aprofundar essas análises brevemente mencionadas, a fim de criar um escopo teórico forte que dará embasamento e desenvolvimento acerca da crítica aqui proposta.

\subsection{CRÍTICA À CONCEPÇÃO JURÍDICA DE 'TRABALHO’}

O item anterior demonstrou a importância do esforço de articulação entre as esferas do mercado e da reprodução para o rompimento de barreiras sexistas do pensamento jurídico-trabalhista, o que, segundo Elisabete Dória Bilac (1989/90, p. 144), exige dois procedimentos: o primeiro é a necessidade de "ampliar o conceito de trabalho para além do espaço produtivo para fazê-lo abranger também as tarefas de reprodução, mesmo quando estas são realizas de forma concreta e não mercantilizada"; o segundo é entender o trabalho como atividade sexuada, ou seja, "nem na esfera da produção nem na da reprodução a relação 'trabalhador-atividade a ser realizada' coloca-se de forma indiferenciada em relação ao sexo". Transplantando essa lógica para a análise do Direito do Trabalho, na sequência serão apresentados o modo como "trabalho" e como “trabalhador” são mobilizados pela disciplina e suas deficiências.

Partimos do entendimento de Judy Fudge e Rosemary Owens (2006, p. 3-4), de que os regimes nacionais de regulação do trabalho baseiam-se em normas de emprego e em pressupostos sobre quem são os trabalhadores e o que eles precisam, derivados de um 
modelo industrial de emprego que, desde a década de 1940, era dominante nas democracias liberais industrializadas. Ademais, as leis trabalhistas e políticas nacionais baseavam-se na divisão do trabalho em que a responsabilidade primária pelo emprego remunerado era dos homens, enquanto às mulheres cabia o trabalho de cuidado não remunerado, refletindo e reforçando, assim, os estereótipos de gênero. ${ }^{55}$

A atenção aqui estará voltada a questionar o modelo normativo de relação de emprego que predominou ao longo do século XX, que é contínua, em tempo integral, na qual "o trabalhador tem um empregador, trabalha sob as premissas do empregador sob sua supervisão direta, normalmente em um setor sindicalizado, e tem acesso a benefícios sociais e direitos que completam o salário social" (VOSKO, 2006, p. 54). As políticas trabalhistas e sociais da maioria dos Estados, no período pós-Segunda Guerra Mundial, foram organizadas em torno desse tipo ideal, pois ainda que variassem entre os países, "as características gerais dessa norma de emprego são, em parte, produto da regulação internacional do trabalho" (VOSKO, 2006, p. 54).

O pano de fundo para essa investigação é o raciocínio de Joanne Conaghan (1999, p.19), que explica que a contribuição da lei para a opressão das mulheres é tanto funcional quanto discursiva, pois "as regras e princípios do Direito do Trabalho não apenas operam diretamente para regular os arranjos de trabalho", como também "operam discursivamente para construir, informar e autenticar entendimentos de gênero desses arranjos". Essa lógica é exemplificada pela ideia pré-concebida de que o envolvimento das mulheres com o trabalho remunerado é subordinado à sua necessidade ou desejo de procriar e de cuidar da prole, o que, por sua vez, contribui para manter e reforçar práticas sexualmente opressivas (CONAGHAN, 1999, p. 19).

\subsubsection{Conceito de trabalho}

“Trabalho" é a noção primordial que sustenta o Direito do Trabalho, confere a ele o estatuto de disciplina autônoma e delimita seu espaço de aplicação. A definição do

\footnotetext{
${ }^{55}$ Fudge e Owens (2006, p. 19-20) também ressaltam o papel da ordem econômica e da globalização em esvaziar a centralidade dos Estados-nação, que originalmente possuem o papel ativo da regulação do mercado de trabalho e são a base territorial das normas trabalhistas, defendendo a necessidade de regulamentar os mercados de trabalho mundiais para evitar que a pressão neoliberal faça com que as nações compitam na redução das proteções trabalhistas.
} 
conceito, porém, é alvo de disputas não apenas entre os juristas, mas também no campo da filosofia e das ciências sociais. Por isso, abordar as fronteiras que definem a noção moderna de "trabalho" é essencial na crítica aqui pretendida, uma vez que ele é a pedra fundamental sobre a qual esse sistema jurídico foi erguido e, por conseguinte, carrega consigo toda a carga ideológica transplantada para o Direito.

Os sentidos e conteúdos compreendidos no termo "trabalho" e sua historicidade são inúmeros, a ponto de precisarem uma tese à parte para que fosse possível abordar toda a complexidade dos debates no Ocidente. ${ }^{56}$ Assim, sugiro uma breve digressão sobre como o trabalho é visto no pensamento de dois autores centrais para o entendimento do sistema econômico nos moldes atuais, Adam Smith e Karl Marx, que são as principais referências para as críticas feministas que serão apresentadas neste item. ${ }^{57}$

Começando com Adam Smith, sem a pretensão de esgotar a leitura do autor, e com ajuda de Daniel Mercure (2003), é importante relembrar que, em A Riqueza das Nações, livro que orientou o nascimento e o desenvolvimento da Economia Política clássica, o autor defende que o trabalho humano é a principal fonte de riqueza e a sua divisão proporciona o aumento da potência produtiva e, portanto, o acúmulo de capital, ainda que limite a vida de uma parcela das pessoas a operações simples e repetitivas (MERCURE, p. 121-123).

Nesse caminho, Adam Smith (2003, p. 18) interpreta a divisão do trabalho como uma "consequência necessária" da "propensão na natureza humana" de trocar uma coisa pela outra. Para o autor, a divisão do trabalho permitiria ao "homem" aproximar-se dessa sua essência, que seria a do homo oeconomicus, o qual, por sua vez, é o protagonista da troca, seja enquanto produtor de mercadoria ou comprador de bens, numa sociedade que é, fundamentalmente, uma sociedade de mercado (MERCURE, p. 123, 129).

Ao abordar o homo oeconomicus, Adam Smith (2003, p. 18-19) ilustra a tal "propensão da natureza humana" à troca - origem da divisão do trabalho - com a seguinte sentença: "não é da benevolência do açougueiro, do cervejeiro ou do padeiro que esperamos nosso jantar, mas da consideração que eles têm pelos próprios interesses".

\footnotetext{
${ }^{56}$ Daniel Mercure e Jan Spurk (2005), em obra dedicada a reconstruir o trabalho na história do pensamento ocidental, partem da noção de trabalho nos filósofos gregos, passando por Santo Agostinho, as reformas protestantes, Adam Smith, Saint-Simon, Durkheim, Karl Marx, Max Weber e pensadores da Teoria Crítica, como Habermas.

${ }^{57}$ Cf.: CARRASCO, 2014.
} 
Assim, ele defende que a harmonia social é fundada em uma dinâmica em que os agentes individuais desconsideram o interesse geral (MERCURE, 2005, p. 129), conforme suas próprias palavras: “apelamos não à humanidade, mas ao amor-próprio, e nunca falamos de nossas necessidades, mas das vantagens que eles podem obter" (SMITH, 2003, p. 19).

O "homem econômico" criou a ilusão de que os seres humanos são indivíduos sem sexo, sem família e sem história, que agem no mercado de forma racional, com foco puramente na vantagem pessoal (FOLBRE; NELSON, 2000, p. 138), lógica que foi contestada posteriormente, especialmente - no que interessa para esta tese - pelas economistas feministas. ${ }^{58}$ Nancy Folbre (2009, p. 305), ao tratar das pesquisas que se propõe ir além do homem econômico (beyond economic man), relata o seguinte:

Esses ensaios explicam que o homem que sabe exatamente o que quer e como obtê-lo por conta própria é uma caricatura dependente das mulheres que o criaram como criança, cuidam de seus filhos e prometem cuidar dele na velhice. Nenhuma sociedade baseada no egoísmo poderia persistir e nenhuma sociedade poderia simplesmente aceitar o altruísmo como um dado (FOLBRE, 2009, p. 305). ${ }^{59}$

Assim, a lógica econômica é desafiada quando os mercados são analisados levando em conta o cuidado, já que por si só eles não são capazes de oferecer o volume e a quantidade do cuidado que é socialmente desejado para crianças, idosos e doentes (FOLBRE; NELSON, 2000, p. 138). Afinal, parece bastante simples tomá-lo como uma expressão natural e biológica do altruísmo familiar, diametralmente oposto ao interesse individual que o rege no mercado, ignorando as importantes dimensões econômicas do cuidado para a reprodução social (FOLBRE, 2014, p. 3).

Cristina Carrasco, Cristina Borderías e Teresa Torns (2011, p. 59) afirmam que a crítica possivelmente mais relevante à Economia clássica - e neoclássica - surge dos limites estabelecidos pela disciplina para seu objeto de estudo, pois fixa fronteiras que consideram somente a economia de mercado, excluindo do "econômico" o trabalho realizado dentro das casas e a relação com a natureza. Isso se soma à falsa ideia de

\footnotetext{
${ }^{58}$ No Direito, a escola de pensamento Law and Economics foi fundada a partir do modelo econômico neoclássico, incorporando os princípios do liberalismo político e na ideia de "homem econômico" de Adam Smith. A crítica a ela desenvolveu-se em diversas frentes, especialmente pelos Critical Legal Studies e, no Brasil, pelo Direito e Subdesenvolvimento. Para o confronto feminista à análise econômica do Direito, cf. FINEMAN; DOUGHERTY, 2005.

${ }^{59}$ Excerto original: "Those essays explain that the man who knows exactly what he wants and how best to get it on his own is a caricature dependent on the women who nurtured him as an infant, care for his children, and promise to care for him in old age. No society based on selfishness could persist, and neither could any society that simply takes altruism as a given".
} 
autonomia do sistema econômico, uma vez que ele depende da natureza e da reprodução da força de trabalho que se concretiza por meio do trabalho de cuidado, sem os quais não poderia existir (CARRASCO; BORDERÍAS; TORNS, 2011, p. 59).

Quanto a Adam Smith, talvez caiba dizer que ele nunca se casou e que viveu com a mãe durante a maior parte da vida, enquanto uma prima cuidava de suas finanças (MARÇAL, 2017, p. 25). Como dito por Katrine Marçal (2017, p. 26), ele conseguiu responder a apenas metade da questão fundamental da Economia, pois "o jantar dele não existia apenas por conta dos interesses pessoais dos comerciantes. O jantar de Adam Smith era servido porque a mãe dele garantia que a comida estivesse sempre à mesa".

O segundo autor relevante para este tópico é Karl Marx, cuja definição de trabalho divide-se em duas, sendo a primeira antropológica, segundo Hirata e Zarifian (2009, p. 251), em que "o trabalho é essencialmente um ato que passa entre o homem e a natureza", constituindo "uma característica genérica da ação humana". Já a segunda definição é uma reinterpretação da primeira, ao considerar que "as trocas entre homem e a natureza sempre se produzem em condições sociais determinadas", por conseguinte, no modo de produção capitalista, "trabalho" seria trabalho assalariado (HIRATA; ZARIFIAN, 2009, p. 252).

Compreendendo esse passo, "processo do trabalho" em $O$ Capital é definido como "atividade orientada a um fim - a produção de valores de uso -, apropriação do elemento natural para a satisfação das necessidades humanas” (MARX, 2013, p. 261). Nesse sentido, Marx trata especificamente do "trabalho assalariado enquanto relação social que organiza atividades humanas especificamente capitalistas", procedendo a separação entre trabalho concreto e abstrato, este que, por sua vez, "cria o valor e, por conseguinte, a mais-valia necessária à acumulação do capital” (MERCURE, 2005, 197).

O mérito dessa dupla definição é que ela situa a atividade do trabalho no ponto de imbricação entre dois tipos de relação, homem-natureza e homem-homem, mas é insuficiente, em especial porque também parte de um "modelo assexuado de trabalho", isto é, o sujeito do trabalho é masculino apresentado como universal, ao mesmo tempo em que abre espaço para que as relações "homem-homem" sejam naturalizadas, enquanto as condições sociais de trabalho são historicizadas, falhando por deixar de considerar, por exemplo, as relações sociais de sexo (HIRATA; ZARIFIAN, 2009, p. 252). 
Voltadas para a escolha de Marx de restringir-se à análise do trabalho executado no âmbito do mercado, as críticas feministas abundam. Silvia Federici (2017a, p. 12) é incisiva ao dizer que "os três tomos de $O$ capital foram escritos como se as atividades diárias que sustentam a reprodução da força de trabalho fossem de pouca importância para a classe capitalista" e como se o consumo dos bens comprados com o salário fossem suficientes para que os trabalhadores se reproduzam. Essa suposição ignora o trabalho das mulheres em preparar esses bens de consumo, bem como que muitos deles “- como açúcar, café e algodão - foram produzidos pelo trabalho escravo empregado, por exemplo, nas plantações de cana brasileiras" (FEDERICI, 2017a, p. 12).

Segundo a autora, o desinteresse de Marx pelo trabalho doméstico deve-se à sua naturalização e desvalorização, que o tornaram, em comparação com o trabalho industrial, "uma forma arcaica que em breve seria superada pelo progresso da industrialização" (FEDERICI, 2017b, p. 101). Ela explica que "Marx deixou a questão de gênero nãoteorizada porque, em parte, a 'emancipação das mulheres' tinha uma importância periférica em seu trabalho político", mas que, independente do motivo, ele de fato naturalizou o trabalho doméstico e idealizou o trabalho industrial "como a forma normativa de produção social e como potencial nivelador das desigualdades sociais" (FEDERICI, 2017b, p. 86). Portanto,

\footnotetext{
ele não conseguiu apreciar a importância estratégica, tanto para o desenvolvimento do capitalismo como para a luta contra ele, da esfera de atividades e relações pelos quais nossas vidas e a força de trabalho são reproduzidas, começando pela sexualidade, a procriação e, primeiro e principalmente, o trabalho doméstico não remunerado das mulheres (FEDERICI, 2017b, p. 86).
}

Continuando a crítica da Economia Feminista em relação à noção de trabalho da teoria marxiana, Cristina Carrasco (2013, p. 43) afirma que os salários pagos pelas empresas em troca do trabalho adquirido permitem adquirir uma série de bens e serviços, mas esses não são, de forma alguma, suficientes para reproduzir a força de trabalho. Por esse motivo, é absolutamente necessária a realização de outros trabalhos voltados a transformar os bens adquiridos no mercado, como alimentos, e realizar serviços de limpeza, gestão e atenção, trabalhos cuja fronteira com o trabalho mercantil é porosa, mudando de acordo com o desenvolvimento tecnológico e os níveis de renda das sociedades e das casas (CARRASCO, 2013, p. 43). 
Exemplo dessa porosidade é que, em épocas de crise como a atualidade, algumas atividades que o mercado incorporou - refeições em restaurantes, compra de produtos já processados, lavagem de roupa na lavanderia etc. - tendem a regressar para as casas. Há também casos em que pessoas realizam diversos tipos de trabalho simultaneamente, sem que haja limite claro entre cada um, ou ainda o trabalho voluntário, que também foge da lógica do interesse mercantil (CARRASCO, 2013, p. 43-44).

Com essas reflexões, as economistas feministas se propuseram a, "atravessando as fronteiras estreitas da economia e observando a realidade para além do paradigma de mercado", incorporar novas análises e, em particular, redefinir o conceito de trabalho (CARRASCO, 2013, p. 47). Nessa linha, Carrasco (2013, p. 46) chama atenção para o fato de que o modelo masculino de trabalho no mercado não é generalizável, já que implica liberdade de tempos e ações, o que não é compatível nem conciliável com as responsabilidades do cuidado e, consequentemente, evidencia que qualquer possibilidade de igualdade só será realizável com uma mudança de modelo, sem que se tente enquadrar as mulheres no modelo masculino de emprego.

Segundo a autora, "a constatação da importância do trabalho de cuidado para o bem-estar e o desenvolvimento das pessoas e das relações humanas" a leva a contrariar a valoração social e a afirmar que é "precisamente o trabalho de mercado que foi desvirtuado e desvalorizado ao eliminar a relação humana que incorporava a experiência feminina do trabalho" (CARRASCO, 2013, p. 49). Assim, o trabalho de mercado teria se tornado empobrecido por lhe ter sido retirada a faceta relacional, que é a parte mais humana do trabalho, do que deriva a importância de recuperar o reconhecimento das atividades que permitem a subsistência e a reprodução dentro do mínimo de humanidade (CARRASCO, 2013, p. 49-50). Carrasco (2013, p. 50, tradução nossa) conclui que

Embora o objetivo genérico [do trabalho de cuidado] seja o de cuidar de todas as pessoas, dar bem-estar à população; há também um objetivo mais específico próprio de uma sociedade patriarcal que é libertar os homens adultos do tempo e das responsabilidades familiares para que eles saiam para trabalhar livres de restrições ao mercado, ao espaço que tenha valor e reconhecimento social em uma sociedade capitalista. $\mathrm{O}$ funcionamento do mercado e do Estado pressupõe esse suporte vital que basicamente as mulheres realizam por meio de uma rede de interdependências - sem o qual não disporiam de força de trabalho socializada e emocionalmente estruturada e segura. ${ }^{60}$

\footnotetext{
${ }^{60}$ Excerto original: “Aunque el objetivo genérico sea el cuidar a todas las personas, dar bienestar a la población; también existe un objetivo más específico propio de una sociedad patriarcal y es liberar de
} 
A contribuição de Susan Himmelweit (1995, p. 5) vai em sentido parecido, sentenciando que "o desenvolvimento pode ser visto como a contínua imposição dessa noção de trabalho sobre outros", ou seja, do trabalho assalariado, dedicado à produção de bens manufaturados para o capital, ainda que essa noção de trabalho seja capaz de capturar de forma restrita e imperfeita a complexidade das relações reais de trabalho em qualquer época. Assim, esse conceito de trabalho é uma abstração, mas ainda assim possui um poder considerável, de modo que as relações de trabalho tendem a se conformar a ela cada vez mais (HIMMELWEIT, 1995, p. 6).

Outra característica do trabalho entendido nos moldes capitalistas, segundo Himmelweit (1995, p. 8), é a irrelevância de quem executa o trabalho, uma vez que deve haver separação entre trabalhador e trabalho para este não ser englobado no produto final, mas nem para todas as atividades domésticas essa separação é possível. Por mais que as formas menos pessoais de trabalho doméstico estejam sendo trocadas por mercadorias compradas, o cuidado das crianças e dos idosos continua a razão mais importante pela qual as mulheres reduzem seu tempo de dedicação ao trabalho remunerado (HIMMELWEIT, 1995, p. 9).

Segundo Danièle Kergoat (2016, p. 18), a crítica feminista permitiu caminhar para uma definição de trabalho não centrada unicamente na valorização do capital, de modo que o trabalho mudou de estatuto, passando de simples "produção de objetos e bens" para "produção do viver em sociedade", ou seja, passando a ser uma atividade política de transformação da natureza, da sociedade e de si mesmo. Ela explica que as teorizações da Sociologia feminista materialista

(...) modificaram a definição clássica de trabalho, demonstrando que o trabalho doméstico, gratuito e excluído do mercado, entrava plenamente na categoria do trabalho explorado, e que a figura do trabalhador 'livre para vender sua força de trabalho' não era a única figura explorada em nossas sociedades. Quanto ao conceito de divisão sexual do trabalho, ele permitiu fazer a ponte entre trabalho doméstico e trabalho assalariado (KERGOAT, 2016, p. 23).

tiempo y responsabilidades familiares a los hombres adultos para que salgan a trabajar libres de restricciones al mercado, al espacio que tiene valor y reconocimiento social en una sociedad capitalista. El funcionamiento del mercado y el Estado presupone ese soporte vital -que realizan básicamente las mujeres a través de una red de interdependencias- sin el cual no dispondrían de fuerza de trabajo socializada y emocionalmente estructurada y segura". 
Dóminique Méda (2010, cap. 1, tradução nossa) identifica e sintetiza três vertentes centrais para a formação do pensamento Ocidental: o trabalho é interpretado, no pensamento cristão, como a "atividade fundamental do homem, que ao mesmo tempo agrega valor ao mundo e a si mesmo, isto é, espiritualiza a natureza e permite o aprofundamento das relações com os outros"; já o pensamento humanista defende uma concepção de trabalho muito próxima da anterior, entendendo-o como "a atividade humana que expressa no mais alto grau a liberdade criativa do homem"; de modo similar, o "pensamento marxista atual, independente da vertente, continua a defender vigorosamente a ideia de que o trabalho é uma categoria central e que constitui a essência do homem". Ademais, interessante destacar que o tal "homem" que executa o "trabalho" nas diferentes vertentes de pensamento descritas por Méda, por mais que seus teóricos reforcem se tratar de um ser humano universal - que corresponderia a qualquer pessoa, independente do gênero, da raça, da classe, da idade e de qualquer outro fator social -, de fato não o é.

Chegando ao contexto da globalização, Isabel Georges (2017, p. 127-128) faz um apanhado dos estudos sobre trabalho na atualidade, descrevendo que desde o final dos anos 1970, o emprego tem perdido sua representatividade na vida de um contingente cada vez maior de pessoas, despossando-se de seu estatuto enquanto gerador de direitos e de proteção social em especial nas sociedades em que o trabalho formal nunca foi generalizado, como no Brasil. Esse diagnóstico de avanço da precarização já foi dado por Robert Castel (1995; 2009) ao falar da desconstrução da sociedade salarial e da institucionalização da precarização, Ricardo Antunes (2009), que apontou as metamorfoses da centralidade do trabalho, e também por Guy Standing (2014) e Ruy Braga (2012), voltados à narrativa da emergência do que chamaram de precariado.

Com todos esses meandros, observa-se que a ideia de trabalho predominante é limitada às atividades relevantes para a contabilidade nacional, tratando-se, portanto, de uma definição restritiva de trabalho que exclui parte substancial dos trabalhos efetuados na vida social, em especial o de cuidado não remunerado (HIRATA, KERGOAT, 2008a, p. 41-42), fruto das correntes teóricas que influenciam com grande peso o pensamento ocidental. Essa visão foi adotada para além da teoria, configurando o imaginário que valoriza o "pescar" ao "dar o peixe" 61 , predominante também do Direito, conforme será

\footnotetext{
${ }^{61}$ Referência ao paralelo feito por Lucy Williams (2005, p. 197), a partir do ditado de que não se pode dar o peixe, mas ensinar a pescar, ao qual ela dirige a seguinte pergunta: mas o que constitui 'pescar' e por que
} 
abordado no próximo tópico.

\subsection{2 'Trabalho' no Direito do Trabalho}

Em uma pesquisa na área do Direito, debruçar-se sobre o conceito de trabalho "entendido em sua face mais ampla como dispêndio de energia física e psíquica pelo homem para a transformação do mundo e a produção de cultura"- justifica-se, nas palavras de Pedro Augusto Nicoli Gravatá (2015, p. 10), por sua correlação heterogênea com o mundo das normas, em especial das normas jurídicas, uma vez que a presença e a significação do trabalho humano são proporcionais à forma como o Direito forjou, ao longo da história ocidental, a disciplina institucional do trabalho.

Sendo assim, levando em conta o panorama anteriormente descrito de mudanças no mundo do trabalho e questionamentos feministas em torno do próprio conceito de trabalho enquanto contraposto ao cuidado - que exigem revisão das oposições como produção e reprodução, público e privado, formal e informal (DEBERT; PULHEZ, 2017, p. 18) -, pretendo desenvolver aqui uma interpelação do Direito a partir da perspectiva de gênero, avançando na trilha já proposta por Everaldo Gaspar Lopes de Andrade (2008; 2014), de criticar a maneira como a teoria jurídico-trabalhista uniformizou, universalizou e recepcionou o trabalho abstrato.

Para fins de sistematização do debate, adoto a proposta de Hillary Charlesworth (1994, p. 70) de observar dois aspectos em que se divide a crítica feminista à dicotomia público/privado no pensamento jurídico ocidental: a forma como o Direito exclui as mulheres do espaço público, que no caso trabalhista decorre da adoção de um modelo de trabalhador que rotula os corpos femininos e os encargos socialmente atribuídos a elas como desviantes; e a separação entre o que merece ou não ser regulado, o que, para fins desta pesquisa, significa abordar a exclusão do trabalho doméstico e de cuidado não remunerado do Direito do Trabalho.

\footnotetext{
'pescar' tem sido entendido como trabalho remunerado dentro da economia formal ao invés de qualquer tipo de trabalho? “'Fishing' assumes an individualistic free-market structure within which any person in waged work can provide adequate income for one's family (...) There is no distinct dichotomy between 'teaching to fish', and 'giving a fish'; indeed, to view the proverb as if there is one presupposes a dichotomy between dependence and independence instead of understanding the interconnection of these complex concepts. 'Fishing' is not a condition of independence; 'fishing' often does not provide for family economic necessities and can create counter-caregiving incentives" (WILLIAMS, 2005, p. 123-124)
} 
Nessa linha, é facilmente observável que os relatos tradicionais do Direito do Trabalho ignoram o trabalho doméstico não remunerado e tomam o trabalho doméstico remunerado como uma exceção, uma modalidade de emprego considerada "especial" (DELGADO, 2017, p. 409 e NASCIMENTO, 2008, p. 1067), que possui características distintas por ser realizado no "âmbito residencial" e ter "natureza não-econômica" ou "finalidade não lucrativa", como registrado no artigo $7^{\circ}$ da CLT e nos artigos $1^{\circ}$ da revogada Lei 5.859/1972 e da Lei Complementar 150/2015.

Conforme Judy Fudge (2011, p. 131), o não reconhecimento do trabalho de cuidado pela Economia, mesmo sendo ele socialmente valioso para a reprodução social, “contribui para a cegueira de gênero do Direito e da política trabalhista". A autora afirma que o trabalho é juridicamente constituído a partir das dicotomias público e privado, trabalho e família, produção e reprodução, mas que a história de construção ativa desse conceito desaparece e as instituições nele fundadas, como o contrato de trabalho, "passam a ser vistas como dispositivos neutros que facilitam as escolhas voluntárias" - como se, por exemplo, fosse escolha das mulheres combinar trabalho assalariado com responsabilidades familiares, livrando o empregador de qualquer preocupação a esse respeito (FUDGE, 2016, p 16).

Como mencionado no início deste capítulo, as teóricas feministas do Direito do Trabalho lançam mão do gênero para demonstrar que o que é considerado "trabalho" varia em diferentes tempos e lugares, revelando, assim, os limites de qualquer interpretação que se diga universal. Logo, afirmações comumente vistas nos manuais e cursos da disciplina juslaboralista, de que "trabalho vem do latim tripalium que era uma espécie de instrumento de tortura" (MARTINS, 2000, p. 168), na aparente tentativa de estabelecer uma relação direta entre a origem etimológica e a função da lei trabalhista, desconsideram a complexidade da formação de sentidos lexicais ${ }^{62}$, como ainda negam a historicidade do conceito.

\footnotetext{
${ }^{62}$ Assumindo as explicações de Cecilia M. Ugartemendía (2018) e Lola Pons Rodríguez (2018), a palavra "trabalho" foi adotada no uso corrente, tanto no Português quanto no Espanhol, mas há outros vocábulos que são usados com o mesmo sentido, como é o caso dos sinônimos trabalhar e laborar, ou trabalhador/a e operário/a. Tendo derivado do latim tripalium, no seu uso mais antigo, falar que algo é trabalhoso de fato quer dizer que é sofrido ou difícil, mas o "trabalho" vem de uma família de palavras nada estável, tendo incorporado diversos significados ao longo da história. Assim: "A fotografia das palavras para o trabalho de cada época nos diz muito sobre como era esse tempo. É um reflexo das sociedades antigas que o sofrimento de ir trabalhar foi comparado com um instrumento perverso de tortura, mas que hoje é estranho para nós. É um reflexo de nossa sociedade atual que as palavras sobre o trabalho que colocamos em circulação ultimamente nos falam de empregos precários (minijobs), com discriminação sexual (las kellys) ou
} 
O pós-Segunda Guerra Mundial é um momento marcante para o Direito do Trabalho, em que o trabalho foi identificado quase que exclusivamente como emprego ou trabalho autônomo nos países desenvolvidos, o que foi possível graças à divisão sexual do trabalho, que sujeitou as mulheres às atividades de cuidado no domínio privado do lar (FUDGE, 2014, p. 4). A casa e a família passaram a ser construídos como "refúgio do trabalho e do mercado, governado por relações afetivas", fazendo arraigar na legislação trabalhista e previdenciária uma noção androcêntrica de trabalho (FUDGE, 2014, p. 10).

Desse modo, o "Direito do Trabalho se desenvolveu como um regime regulatório ou uma jurisdição para lidar com os problemas relacionados ao controle do trabalho e alocação da força de trabalho", com premissas próprias, que se fixam no esforço de balancear as relações entre quem trabalha e quem emprega, e técnicas específicas, como a negociação coletiva, enquanto o cuidado foi tratado como parte das relações privadas da família, que não deveriam sofrer interferência (FUDGE, 2014, p. 11). Consequentemente, as doutrinas e instituições jurídicas contemporâneas assimilaram fronteiras rígidas entre casa e mercado, privado e público, a ponto que a "classificação jurisdicional inicial parece natural e inevitável e não política e ideológica" (FUDGE, 2014, p. 11).

Esse é um dos motivos pelos quais o trabalho doméstico remunerado perturba os critérios convencionais jurídico-trabalhistas, uma vez que o fato de ele ser executado dentro dos lares, em espaço que seria próprio das relações familiares, gera dúvidas sobre a qual lado da fronteira pertence. Judy Fudge (2014, p. 16) afirma que as especificidades do trabalho doméstico em relação ao emprego são legado de uma "atribuição prévia de jurisdição" e da forma de institucionalização dessas relações, que determinaram o enquadramento do cuidado não remunerado no Direito de Família ${ }^{63}$, construções que são contestáveis, ou seja, em momento algum auto-evidentes como se faz parecer.

A autora argumenta pela extensão do Direito do Trabalho para que inclua todos os processos da reprodução social, o que não significa, segundo ela, defender que se aplique ao trabalho de cuidado não remunerado a legislação existente, concebida a partir de uma noção do trabalho muito específica, mas sim desnaturalizar os limites da

deixando sem vida própria o workaholic. Outras vezes a palavra permanece, mas muda a realidade do trabalho a que se refere" (RODRIGUEZ, 2018, tradução nossa).

${ }^{63}$ Este, por sua vez, baseou-se em normas burguesas de casamento, família e domesticidade, âmbito associado ao amor e em oposição ao trabalho que é associado ao dinheiro, servindo para ocultar que o casamento é historicamente uma forma de suprir necessidades econômicas (FUDGE,2016, p. 13). 
disciplina e cultivar uma perspectiva crítica (FUDGE, 2014, p. 20). Com isso, Fudge (1996, p. 252) pretende evidenciar que

[o] Direito do Trabalho também assume como certa a forma particular das relações produtivas capitalistas. Assume que as relações de emprego devem ser organizadas hierarquicamente com base em diferenciais de habilidade. O Direito do Trabalho geralmente ignora a extensão em que a habilidade é socialmente construída como resultado das lutas, tanto entre empregadores e trabalhadores quanto entre diferentes grupos de trabalhadores. $^{64}$

Portanto, o essencial é frisar que a noção de trabalho não é única, não podendo ser simplificada ou reduzida à sua representação dominante dentro de determinado período histórico. Nesse sentido, Everaldo Gaspar Lopes de Andrade (2008, p. 20) critica os princípios que fundamentam o Direito do Trabalho por estarem conectados ao que ele chama de "ideologia do trabalho assalariado - vendido, comprado e separado da vida" e a um imaginário de Estado de Bem-Estar Social e pleno emprego que não são uma realidade para o Brasil e demais países do Sul. Sua proposta, que se alinha à desta tese, é de "questionar, problematizar e refutar os princípios do Direito do Trabalho, ou seja, sua pretensão de validade e de universalidade, de verdades fundantes" (ANDRADE, 2008, p. 20).

Seguindo os passos do autor, é relevante trazer para análise alguns dos teóricos que são referência nos estudos juslaboralistas brasileiros, uma vez que eles - e dizemos eles no masculino porque, de fato, são quase que exclusivamente homens - são os responsáveis pela criação de grande parte do imaginário e dos fundamentos da disciplina jurídica-trabalhista como entendida hoje na América Latina. Passarei rapidamente por Mario de La Cueva, Ernesto Krotoschin, Antonio Ferreira Cesarino Jr. e Américo Plá Rodriguez, atentando para o pano de fundo do que cada um deles entende e anuncia sobre o Direito do Trabalho.

Mario de la Cueva (1977, p. 92, 104, tradução nossa) descreve o Direito do Trabalho como "o Direito da classe trabalhadora" ou "Direito protetor da classe trabalhadora", a qual ele entende como a "multiplicidade de homens que ocupa no processo econômico uma posição não só distinta, como oposta à burguesia”. Além disso,

\footnotetext{
${ }^{64}$ Excerto original: "Labour law also takes a particular form of capitalist productive relations for granted. It assumes that employment relations must be organized hierarchically on the basis of skill differentials. Labour law generally ignores the extent to which skill is socially constructed as a result of the outcomes of struggles, both between employers and workers and between different groups of workers".
} 
o autor defende a "ideia do trabalho como um direito e um dever sociais", vislumbrando uma "sociedade futura" em que "o trabalho, entendido como valor supremo, será um dever criador de direitos" (CUEVA, 1977, p. 107). Ele mesmo assume que a limitação da aplicação do Direito do Trabalho ao "trabalho subordinado que se presta a outro em relação de subordinação" é limitada, entendendo que "em um futuro próximo devem ser expedidas leis apropriadas, até integrar uma legislação unitária para o trabalho do homem" (CUEVA, 1977, p. 163, 154), mas não se atém à problemática gerada por essa escolha.

Ernesto Krotoschin (1977, p. 3) afirma a dificuldade de definir trabalho enquanto um dos elementos constitutivos do Direito do Trabalho, concluindo que por sua acepção ser muito ampla, prevaleceu o entendimento de que para a disciplina só interessa o "trabalho efetuado em situação de dependência ou subordinação", dependência que não seria "sintoma" de um sistema socioeconômico determinado, mas de uma condição prévia para a aplicação da norma trabalhista. Para ele, há certas classes de serviços que não têm como base uma relação jurídica de trabalho, citando como exemplo o "trabalho familiar", que seria o "dever de assistência mútua" que os cônjuges possuem, hipótese na qual a "prestação de serviços deriva de um vínculo matrimonial, como uma consequência assessória deste", não sendo objeto do Direito do Trabalho, pois não se admite contrato de trabalho entre cônjuges. (Krotoschin, 1977, p. 99-100).

Observa-se claramente que Krotoschin toma como natural, como algo que não aventa questionamento, o arranjo familiar baseado no contrato matrimonial - forma assumida pelo contrato sexual ${ }^{65}$-, o qual, bem disfarçado por essa roupagem de “assistência mútua" e coroado pelo amor romântico, perpetua o patriarcado, tacitamente impondo que a esposa execute o trabalho de cuidado para o marido dentro de casa, de forma gratuita, o que o deixa "livre" para exercer atividades remuneradas na esfera pública (PATEMAN, 1993, p. 176).

Cesarino Jr. (1970b, p. 5) afirma que, para efeitos do Direito do Trabalho, o conceito deve ser de trabalho subordinado, que ele entende como "hierarquicamente

\footnotetext{
${ }^{65}$ O "contrato sexual" é a resposta de Carole Pateman (1993) aos teóricos contratualistas, por meio do qual a autora revela a "metade da história não contada" da formação do Estado Moderno. Segundo ela, "a sociedade civil patriarcal está dividida em duas esferas, mas só se presta atenção a uma delas. A história do contrato social é tratada como um relato da constituição da esfera pública da liberdade civil. A outra esfera, a privada, não é encarada como sendo politicamente relevante. O casamento e o contrato matrimonial também são considerados, portanto, politicamente irrelevantes. Ignorar o contrato matrimonial é ignorar metade do contrato original" (PATEMAN, 1993, p. 18).
} 
dependente de um empregador". Ele também explica que o trabalho familiar não é alvo de contrato de trabalho, por ser "realizado por pessoas da família" como "manifestação do poder marital ou pátrio", mas utiliza da jurisprudência francesa para justificar a possibilidade de indenização da esposa por serviços prestados ao marido por ele ter agido como empregador, em oposição ao dever principal do "poder marital" que seria de “proteção da mulher" (CESARINO JR., 1970b, p. 114). Vale lembrar que o texto data de 1970, época em que o Estatuto da Mulher Casada (Lei 4.121/1962) as excluía da condição de relativamente incapazes imposta pelo Código Civil de 1916.

Quanto a Américo Plá Rodriguez (2000, p. 66-67), em sua teoria geral descreve o surgimento das normas trabalhistas como consequência da inferioridade econômica do trabalhador frente ao empregador, desigualdade que só se corrigiria com "desigualdade no sentido oposto", tendo como ponto de chegada a melhoria das condições dos trabalhadores. Os aclamados princípios que regem sua teoria são por ele definidos como "linhas diretrizes que informam algumas normas e inspiram direta ou indiretamente uma série de soluções, pelo que podem servir para promover e embasar a aprovação de novas normas, orientar a interpretação das existentes e resolver os casos não previstos" (PLÁ RODRIGUEZ, 2000, p. 36).

A crítica de Everaldo Gaspar de Lopes Andrade (2008) ao autor uruguaio vai no sentido de que os princípios do Direito do Trabalho carregam consigo uma noção estrita de trabalho enquanto trabalho subordinado, podendo eu acrescentar que carregam também a noção trabalho produtivo. Ora, se os princípios de fato são "linhas diretrizes" que regem todo o funcionamento do Direito do Trabalho, tal como descreve Plá Rodriguez, eles carregam para dentro da lógica jurídico-trabalhista o sexismo impregnado na dicotomia trabalho produtivo e reprodutivo, o que revela que os próprios fundamentos da disciplina merecem ser repensados.

Assim, "a quase unanimidade do pensamento jurídico de vários continentes reduz a definição do Direito do Trabalho a um conjunto de princípios e regras dirigidas ao trabalho subordinado, dependente, por conta alheia", reducionismo que, segundo Andrade (2008, p. 219) encontra justificação no modelo de sociedade capitalista industrial e na ideia de trabalho-dever. Entretanto, diante da perda da supremacia do setor de trabalho formal, da predominância do setor de serviços e do aumento do trabalho informal e precário, o "labor dependente, subordinado ou por conta alheia, não pode ser mais elevado à condição de objeto do Direito do Trabalho" (ANDRADE, 2008, p. 220). 
Assim, a conclusão de Everaldo Gaspar de Lopes Andrade (2008, p. 73) é a de que o Direito do Trabalho deve fazer-se e refazer-se continuamente, seguindo um ciclo que parte dos fenômenos sócios-laborais - como greves, pressões e embates individuais e coletivos -, os quais formam o substrato que desencadeia a criação, a atualização e a recriação do que ele chama de Teoria do Conhecimento Jurídico-Trabalhista, de onde se constrói a normativa e a dogmática jurídica. Isso significa dizer que não se pode sonhar com um Direito do Trabalho criado em berço de ouro, elaborado por pensadoras e pensadores iluminados que saberão o que é melhor para o cotidiano das relações de trabalho; muito pelo contrário, ele precisa responder às demandas sociais.

Referenda esse raciocínio Maria do Rosário Palma Ramalho (2000, p. 697), em que afirma que o desenvolvimento sistemático do Direito do Trabalho, na maioria dos países, assentou-se na "uniformidade do estatuto laboral, traduzida na ideia de relação de trabalho "típica"'. Constatando a erosão desse padrão a partir da proliferação de formas marginais de trabalho e as cada vez mais frequentes tentativas de burlar da legislação trabalhista - realidade de Portugal, mas que, nas devidas proporções, aplica-se ao Brasil também -, a autora constata não só uma crise do Direito do Trabalho, mas uma crise de seus valores, afirmando não ser mais possível que a relação de trabalho 'típica' mantenha sua posição dominante no sistema (RAMALHO, 2000, p. 10, 697).

Tomar esses doutrinadores como referência permite ver com mais clareza que o “conteúdo substantivo da narrativa teórica dominante baseia-se na bifurcação das relações industriais e, portanto, do Direito do Trabalho, em dois grupos distintos - capitalistas e trabalhadores - com interesses conflitantes", o que afetou a absorção das questões de trabalho/família, uma vez que o modelo geral de conflito de classes ocorre no local de trabalho (CONAGHAN, 2005, p. 24). Ao mesmo tempo, as questões de trabalho/família foram tomadas como particularidades relacionadas às mulheres, não ao trabalho no geral, deixando-as, no melhor dos casos, relegadas às margens do Direito do Trabalho, ou pior, posicionadas como desviantes (CONAGHAN, 2005, p. 24-25).

Outro ponto a considerar, como observado por Bridget Anderson (2003, p. 113), é que o trabalho é um processo social, não simplesmente econômico. Na vida de uma trabalhadora doméstica, por exemplo, isso significa que ela poderá decidir trabalhar por um salário mais baixo precisamente porque acredita que uma família em particular é agradável ou porque um empregador a trata como parte da família, ainda que essa escolha não seja economicamente justificável (ANDERSON, 2003, p. 113). Isso significa que não 
se pode ignorar a realidade cotidiana das trabalhadoras do cuidado, uma vez que historicamente os problemas emocionais interferem na escolha e formalização das relações de trabalho.

Voltando à análise das relações de emprego tomadas como padrão, ou seja, aquelas que derivam do modelo masculino e fabril de trabalho, Fudge e Owens (2006, p. 19-20) chamam a atenção para que esse padrão se tornou "a base da proteção social e do direito trabalhista", o que do ponto de vista institucional significou a triangulação entre empresas, sindicatos e Estado”. A essa configuração, as autoras dão nome de Direito do Trabalho fordista, que prevaleceu não apenas no âmbito dos países de industrialização avançada, mas internacionalmente, via Organização Internacional do Trabalho, e nos demais países, ainda que com limitações (FUDGE; OWENS, 2006, p. 20).

É interessante notar que a própria OIT foi uma das responsáveis por adotar, durante um longo período, as relações de emprego fordistas como padrão, tratando o trabalho das mulheres como forma marginal ou periférica de trabalho, que estariam fora do alcance da organização (FUDGE; OWENS, 2006, p. 20). Como relata Leah Vosko (2006, p. 56), as normas internacionais do trabalho que normalizaram a relação de emprego padrão foram também centrais para incutir no Direito do Trabalho o contrato sexual, reforçando a separação entre os papéis de "provedor" e "cuidadora". Assim fizeram a Convenção n. 1, de 1919, que fixou a limitação da jornada de trabalho, excluindo dela as trabalhadoras e trabalhadores em empresas familiares - "para preservar a santidade da esfera privada"; a Convenção n. 3 , de proteção à maternidade, e a Convenção n. 4, sobre trabalho noturno das mulheres, ambas de 1919, que incentivavam o confinamento das mulheres em casa (VOSKO, 2006, p. 56).

Foi só posteriormente, graças à pressão política de grupos de mulheres e organizações não-governamentais, que a OIT mudou seu escopo e passou a incluir em sua perspectiva "formas de trabalho não padronizadas",66, o que pode ser exemplificado pela Convenção n. 175, concernente ao Trabalho a Tempo Parcial, seguida pela Convenção n. 177, sobre o Trabalho Domiciliar, de 1994 e 1996, respectivamente (FUDGE; OWENS,

\footnotetext{
${ }^{66}$ A atual concepção que rege a OIT, de trabalho decente, é mais ampla que o anterior domínio da relação de emprego padrão e da lei trabalhista fordista, segundo Fudge e Owens (2006, p. 20-21), demonstrando o esforço da organização em trazer trabalhadoras e trabalhadores antes excluídos de sua regulamentação para seu escopo de atuação, mais um indicativo da necessidade de revisar as bases do Direito do Trabalho. Para análise da concepção de trabalho decente, cf. MAEDA, 2017.
} 
2006, p. 20). Merece ser lembrada, ainda, a Convenção n. 189, de 2011, voltada às trabalhadoras domésticas, que será tema de item específico do capítulo 3.

Por fim, para fechar este tópico, vale mencionar a proposta de Judy Fudge (2011, p. 120) de reinterpretar a narrativa que predomina entre os teóricos do Direito do Trabalho sob a luz de categorias e problemas que passaram por baixo de sua superfície, esforço que parte da compreensão do trabalho como uma mercadoria fictícia (fictive commodity ${ }^{67}$ ). Retomando a afirmação de que "uma forma específica de regulação, em um determinado momento no tempo, passou a ser vista como a forma, e não como uma forma, do Direito do Trabalho", ela descreve a emergência da disciplina como plataforma principal para fornecer os direitos da cidadania industrial a partir dos anos 1930, muito ligada à política econômica dos Estados hegemônicos (FUDGE, 2011, p. 121). Sendo assim, o propósito do Direito do Trabalho é regular as relações de emprego de modo a garantir que elas funcionem com sucesso enquanto transações de mercado, protegendo minimamente trabalhadoras e trabalhadores contra a lógica econômica (FUDGE, 2011, p. 123).

Dentro desse contexto, é necessário compreender que a "força de trabalho é encarnada em seres humanos que nascem, são cuidados e tratados em uma rede de relações sociais que opera fora da disciplina direta do mercado", tendo a capacidade de agir individualmente e de resistir coletivamente, diferente de mercadorias (FUDGE, 2011, p. 130). Tendo isso em vista, é insuficiente que o Direito do Trabalho aborde problemas de controle e alocação da força de trabalho, ou que regule a negociação coletiva e confira padrões mínimos de saúde e segurança, devendo preocupar-se também com dilemas regulatórios relacionadas à oferta de trabalho e à reprodução social, evitando negligenciar

\footnotetext{
${ }^{67}$ A ideia, já presente em Marx, desenvolvida por Polanyi no Capítulo 6 de A Grande Transformação, é de que trabalho, terra e dinheiro são "mercadorias fictícias", porque não são produzidas como mercadoria e sua produção não é governada pelo mercado. Nas palavras do autor, “(...) trabalho, terra e dinheiro são elementos essenciais da indústria. Eles também têm que ser organizados em mercados e, de fato, esses mercados formam uma parte absolutamente vital do sistema econômico. Todavia, o trabalho, a terra e o dinheiro obviamente não são mercadorias. O postulado de que tudo o que é comprado e vendido tem que ser produzido para venda é enfaticamente irreal no que diz respeito a eles. (...) Trabalho é apenas um outro nome para atividade humana que acompanha a própria vida que, por sua vez, não é produzida para venda, mas por razões inteiramente diversas, e essa atividade não pode ser destacada do resto da vida, não pode ser armazenada ou mobilizada. (...) Nenhum deles é produzido para a venda. A descrição do trabalho, da terra e do dinheiro como mercadorias é inteiramente fictícia" (POLANYI, 2000, p. 94).
} 
grandes contingentes de trabalho realizados de forma invisível ao mercado (FUDGE, 2011, p. 131).

Portanto, se o cuidado é essencial para a reprodução social, tratá-lo como trabalho, e não como obrigação para as mulheres, é um grande passo - e talvez uma obrigação - para uma profunda reconceituação do Direito do Trabalho, não existindo uma razão conceitual que, a priori, impeça esse movimento (FUDGE, 2011, p. 132). Com isso, a autora agrega a dimensão do cuidado à proposta de Alain Supiot et. al. (2016, Synthèse du Rapport) de que o estatuto profissional que determina a proteção trabalhista não seja mais determinada a partir da noção restritiva de emprego, mas pela noção ampliada de trabalho.

\subsection{O CONTROVERSO MODELO DO TRABALHADOR UNIVERSAL}

A relação típica de trabalho sobre a qual se fundamenta o Direito do Trabalho, conforme visto no item anterior, vem atrelada ao sujeito que participa da relação juridicamente tutelada e que, nesse caso, é o trabalhador homem, com um contrato de trabalho em tempo integral, emprego fabril, sindicalizado, possivelmente de um país do Norte e auxiliado por uma mulher que realiza as tarefas domésticas de cuidado - seja mãe, esposa, sogra etc. A pretensão universalizante do sujeito de direito não é novidade para as análises críticas do Direito ${ }^{68}$, que há gerações debatem sua especificidade histórica $^{69}$ e seu vínculo com a produção capitalista ${ }^{70}$. É, entretanto, a faceta sexista do sujeito que permeia toda a formulação juslaboralista que será abordada neste tópico.

\footnotetext{
${ }^{68}$ Pasukanis (1989, p. 165), por exemplo, afirma que "toda a relação jurídica é uma relação entre sujeitos", atomização que dificulta a acepção da classe e, por conseguinte, anula seu potencial revolucionário. Para um panorama dos debates sobre o sujeito de direito em Kant, Hegel e Marx, incluindo a interpretação de teóricos do direito a esse respeito, cf. KASHIURA JR., 2014.

${ }^{69}$ Cf.: NAVES, 2014.

${ }^{70}$ Conforme Celso Naoto Kashiura Jr. (2014, p. 12), a forma sujeito de direito é determinada pelo processo do valor de troca e está intimamente conectada à forma mercadoria, surgindo como forma social específica do modo de produção capitalista. "O sujeito de direito, determinado imediatamente pela circulação mercantil, na qual figura como 'guardião' de mercadorias, plenamente capaz de realizar atos voluntários em relações de igualdade e liberdade com quaisquer outros sujeitos de direito, é determinado, em última instância, pela produção especificamente capitalista, mais precisamente pela subsunção real do trabalho ao capital, que, ao realizar na prática o trabalho abstrato, realiza na prática a equivalência subjetiva jurídica" (KASHIURA JR., 2014, p. 241)
} 
Ainda que no mundo do trabalho as mulheres sejam "tudo menos uma minoria", tendo uma contribuição indispensável na e para a força de trabalho (MARUANI, 2016, p. 69), o Direito do Trabalho tradicionalmente focou no modelo masculino vinculado à economia formal acima descrito, que nunca foi suficientemente inclusivo para abraçar as relações por ele tuteladas. Por conseguinte, as mulheres e as pessoas pobres dedicadas ao trabalho assalariado, formal ou informal, e ao trabalho de cuidado foram ignoradas na sua formação (WILLIANS, 2005, p. 212).

Conforme Carole Pateman (1993, p. 200), a categoria "trabalhador" é contratualmente universal e aplicável a todos que ingressam no mercado capitalista e vendem sua força de trabalho. No entanto, "a construção do trabalhador pressupõe que ele seja um homem que tem uma mulher, uma dona-de-casa, para cuidar de suas necessidades cotidianas", numa relação de sustentação mútua entre contrato de trabalho e contrato sexual (PATEMAN, 1993, p. 196). ${ }^{71}$

Nessa linha de raciocínio, Joanne Conaghan (1999, p. 25) aponta como uma falha dos economistas neoclássicos a representação do local de trabalho como uma entidade autônoma e autogovernada, pressupondo a separação conceitual e prática entre "trabalho" e "vida familiar" que é artificial e enganosa, uma vez que a "dinâmica fundamental do local de trabalho - quem o ocupa e em que termos - é moldada, em grande parte, pela alocação de poder e responsabilidade dentro da família”. A autora continua, afirmando que

uma manifestação prática desta falha conceitual tem sido a adoção
tradicional pelo Direito do Trabalho de um trabalhador paradigmático
que é (ou era) biográfica e empiricamente masculino: trabalhador em
tempo integral, geralmente sindicalizado, sem responsabilidades
domésticas além do provimento financeiro. Isso contribuiu para a
exclusão prática de muitas mulheres trabalhadoras dos benefícios da
negociação coletiva e da proteção legislativa. A separação conceitual do
trabalho e da família também dificultou a eficácia dos esforços
legislativos para promover a igualdade sexual, incentivando um foco
nas práticas do local de trabalho isoladas de arranjos sociais mais
amplos, particularmente aqueles que governam a esfera doméstica
(CONAGHAN, 1999, p. 26). ${ }^{72}$

\footnotetext{
${ }^{71}$ Para aprofundamento e visões complementares, cf.: DELPHY, 1992 e TABET, 2004.

${ }^{72}$ Excerto original: "One practical manifestation of this conceptual failing has been the traditional adoption by labour law of a paradigmatic worker who is (or was) biographically and empirically male: the full time, long term, generally unionised worker with no domestic responsibilities beyond that of financial provision. This has contributed to the practical exclusion of many women workers from the benefits of collective bargaining and legislative protection. The conceptual separation of work and family has also hampered the effectiveness of legislative efforts to promote sexual equality, by encouraging a focus on
} 
Segundo a autora, outra dimensão problemática da narrativa implícita no discurso econômico diz respeito à "concepção de gênero da natureza humana e do comportamento humano", pois a ideia de "ator racional autônomo que interage livremente no mercado em busca de seu próprio interesse é um constructo masculino" reforça valores e experiências masculinas (CONAGHAN, 1999, p. 35). Essa construção ao redor do "homem econômico", mencionada em tópicos anteriores, impedem que se levem em conta outros fatores que regem o comportamento humano além do interesse próprio, como o altruísmo ou a empatia, bem como ignora a maneira pela qual "identidade e preferências individuais são mediadas por múltiplas experiências e alianças" (CONAGHAN, 1999, p. 35-36).

Ademais, a "própria noção de sujeito universal como base para a teorização econômica conflita diretamente com uma ênfase feminista na particularidade do sujeito cujo conhecimento 'situado' informa e orienta a tomada de decisões" (CONAGHAN, 1999, p. 36). Dessa forma, consoante a autora, a aplicação ao Direito do Trabalho do modelo transportando da economia tradicional produz conclusões que são politicamente contestáveis, ainda que se argumente por sua validade 'científica', pois fecha os olhos a uma pretensa neutralidade que esconde ideologia (CONAGHAN, 1999, p. 36).

Como bem demonstra Judy Fudge (1996, p. 240), os manuais de Direito do Trabalho aparentam partir de uma ideia de trabalhador assexuado, mas na verdade utilizam-se do padrão masculino, que deriva da ideia de que ele é a norma, sendo portanto invisível, enquanto o sexo feminino é o desviante ou problemático, que precisa ser demarcado. Logo, o sexo se torna um "problema" quando a trabalhadora é uma mulher, motivo pelo qual elas figuram no Direito de um modo peculiar, em categorias específicas - como maternidade, lactação, igualdade na contratação, revistas íntimas e proteção à saúde -, marcadamente definidas por sua biologização ${ }^{73}$ (FUDGE, 1996, p. 240).

Como ilustração, é possível citar Mário de la Cueva (1977, p. 153), que afirma que "o Direito do Trabalho nasceu para proteger a atividade do homem, motivo pelo qual suas normas e instituições pressupõem a presença da pessoa humana", exemplificando que as previsões de limitação de jornada, dias de descanso e férias, o salário etc. têm

workplace practices in isolation from broader social arrangements, particularly those governing the domestic sphere".

${ }^{73}$ Tratei com mais profundidade do olhar biologicista do Direito sobre o trabalho das mulheres no item 2.3 de minha dissertação de mestrado. Cf.: VIEIRA, 2014. 
como finalidade assegurar uma existência decorosa e a preservação das condições físicas de trabalho. Assim, nas palavras do autor, "o homem-trabalhador é o eixo em torno do qual gira o estatuto laboral: Parece-me que, de fato, ele estava falando do homem, já que não cogitou em momento algum que a garantia de uma existência decorosa dependia também da vida fora do mercado de trabalho, de tempos dedicados a atividades fora da sua esfera remunerada.

De modo similar, ao definir os sujeitos do Direito do Trabalho, Ernesto Krotoschin (1977, p. 90, tradução nossa) coloca em primeiro plano o que ele chama de "trabalhador dependente", definido como "o indivíduo que presta trabalho remunerado a outro (empregador ou 'patrão'), por meio de relação jurídica que pela vontade das partes implica dependência em sentido laboral". Segundo o autor, o Direito do Trabalho é o Direito dos trabalhadores e empregadores, quando partes da relação laboral caracterizamse pelo propósito de proteger os mais débeis (KROTOSCHIN, 1977, p. 10).

Ambos os juristas relevam a limitação do que a disciplina juslaboralista encara como trabalhador-referência para suas normas, ancorado estritamente em relações que devem ter pessoalidade, subordinação, habitualidade e onerosidade, que no imaginário da jurídico-trabalhista, facilmente visualizado no modo como os títulos da CLT são apresentados, dizem respeito a trabalhadores no masculino "universal", até que se deparam com o excepcional "trabalho da mulher" (Título III, Capítulo III).

A ideia de universalidade na norma jurídica reflete uma tradição ideológica herdada pela Revolução Francesa, que privilegia uma forma abstrata "universal" como a garantia de igualdade perante a lei, enquanto implica a fechar os olhos para as diferenças; a igualdade puramente jurídica deixa intacta as desigualdades de fato, podendo até agravá-las (LOCHAK, 2010, p. 11). Nesse âmbito, a perspectiva feminista, em especial o cuidado em oposição ao individualismo normativo, permite observar que por mais que os mercados pressuponham a existência de indivíduos "independentes e competitivos, com capacidade jurídica para contratar", eles estão ancorados à esfera privada que lhes proporciona amparo e permitem sua reprodução (DALY; LEWIS, 2000, p. 284).

Ainda assim, ilusoriamente, o "trabalhador ideal" para o modelo jurídico trabalhista é aquele que não possui obrigações relativas ao cuidado, podendo assumir compromisso total com o empregador (MATTAR, 2001, p. 91). Nesse caso, com a carga de cuidado recaindo mais frequentemente nas mulheres, pelas razões já tratadas ao longo deste estudo, elas dificilmente conseguirão se dedicar ao trabalho com o mesmo nível de 
atenção exigido pelos empregadores e referendado pela legislação, ficando em defasagem em relação aos homens e reforçando a segregação do mercado de trabalho por gênero.

Martha Albertson Fineman (1992, p. 231) defende que por mais que a paternidade tenha sido transformada na modernidade, afastando-se de representar quase que exclusivamente a responsabilidade socialmente atribuída aos homens de dar sustento econômico à casa, o modelo da "família tradicional" ainda é fundamento para a legislação, sendo responsável por reforçar, recriar e reiterar valores fundamentais, tais como a ideia de que o cuidado das crianças é uma tarefa primordialmente privada.

Vale, outrossim, destacar que a lei não se limita a regular o mundo do trabalho, em sentido mais estrito as relações de emprego, mas constitui as categorias e os conceitos por meio dos quais esse mundo é visto e interpretado (CONHAGHAN, 2014, p. 15). Consequentemente, a emergência temporal e espacialmente localizada do contrato de trabalho "como uma categoria com consequências legais contribuiu para a construção e reificação de uma ideologia das relações de trabalho nas quais a forma contratual é privilegiada" (CONHAGHAN, 2014, p. 15). ${ }^{74}$

Ainda que as questões de gênero sejam, hoje, uma preocupação para juristas e advogados trabalhistas, seu impacto sobre a compreensão de seu campo é bastante restrito, pois ainda que o ideal normativo do homem chefe de família provedor (male breadwinner) e da mulher cuidadora tenha sido forçadamente deixado de lado pelas mudanças nas formas de organização do trabalho e da família que atendem às regras do capitalismo pós-industrial globalizado (CONAGHAN, 2014, p. 3), o ideal de “trabalhador” no qual elas se ancoram não mudou.

Nesse sentido, Susan Moller Okin (1989, p. 5) assevera que o antigo, e ainda velado, pressuposto de que os trabalhadores têm esposas ou mães em casa é construído não apenas pelas expectativas dos empregadores, mas também de outras cruciais instituições sociais, por exemplo as escolas, que não levam em conta as necessidades dos pais e mães que trabalham ao estipular horário de aula de férias. Apesar disso, "nada em nossas naturezas dita que homens não deveriam ser participantes iguais na criação de suas crianças" e "nada na natureza do trabalho faz com que seja impossível ajustá-lo ao fato de

\footnotetext{
${ }^{74}$ Tradução livre de: “(...) the emergence of the contract of employment at a particular time and place as a category with legal consequences has contributed to the construction and reification of an ideology of work relations in which that particular form is privileged".
} 
que pessoas são pais/mães bem como trabalhadores" (OKIN, 1989, p. 5). A esse respeito, a autora completa:

Se começarmos com a suposição razoável de que as mulheres e os homens são igualmente pais de seus filhos e têm a mesma responsabilidade tanto pelo esforço não remunerado que envolve o seu cuidado quando pelo apoio econômico, então devemos repensar as demandas da vida profissional durante todo o período em que o trabalhador seja pai ou a trabalhadora seja mãe de uma criança pequena. Não podemos mais nos apegar à suposição em grande parte mítica de que todo o trabalhador tem 'alguém' em casa para criar 'seus' filhos (OKIN, 1989, p. 175-176).

Daí a importância de que estudiosos que integram a área do Direito do Trabalho levarem a sério as preocupações feministas, não como esfera apartada dedicada às mulheres, mas como forma de interpretação crítica da disciplina, de modo a, nas palavras de Joanne Conaghan (2014, p. 4), reconceituar trabalho em termos que atinjam "além do emprego"75, "englobando o significado e as implicações do trabalho de cuidado não remunerado para o campo regulatório como um todo", mas também desviando um pouco seu foco tradicional na relação empregado-empregador.

Em termos objetivos, desafia-se o pensamento jurídico trabalhista que coloca as mulheres à margem, dando enfoque à perspectiva de gênero, de modo a evitar que as questões relativas à reprodução da vida - como a gravidez - e ao cuidado não sejam tratadas como exceções no trabalho, mas como parte intrínseca de sua organização. Por conseguinte, abre-se espaço para desvelar a "profunda crise ideológica no coração do discurso tradicional do Direito do Trabalho", que é o "colapso do trabalhador homogêneo e do quadro normativo que pretende servi-lo" (CONAGHAN, 1999, p. 21). ${ }^{76}$

Portanto, não é possível considerar que há neutralidade, objetividade ou universalidade no Direito do Trabalho se seu referencial é masculino e, por conseguinte, a legislação que toma o trabalhador masculino como padrão acaba por reforçar a desigualdade de gênero. Seja pelo aspecto de não considerar as mulheres em seu padrão de trabalho a ser protegido, seja por excluir certos tipos de trabalho socialmente atribuídos às mulheres - como é o caso do cuidado não remunerado - de suas atribuições, o Direito do Trabalho falha por não cumprir sua promessa de universalidade, tendo muita

\footnotetext{
${ }^{75}$ Cf.: SUPIOT et. al., 2016, já citado anteriormente.

${ }^{76}$ Tradução livre de: “(...) the deep ideological crisis at the heart of traditional labour law discourse - the collapse of the homogeneous worker and the collective framework which purports to serve him".
} 
dificuldade de incorporar em sua lógica a existência da esfera doméstica, em lógica similar à descrita por Laura Davis Mattar (2001, p. 82) sobre o Direito Internacional.

Pensar em uma nova chave do Direito do Trabalho com a ideia de trabalho e de trabalhador diferente, que fuja de padrões masculinos, evita que se tenha que viver sobre a "corda bamba" de equilibrar a proteção necessária à maternidade e ao cuidado de um lado e o incentivo à participação no mercado de trabalho e sua não-discriminação, de outro. Isso também permite questionar os padrões de tempo e mensuração do trabalho no ordenamento jurídico-trabalhista, uma vez que eles ignoram a necessidade do cuidado cotidiano, seja voltado para pessoas dependentes ou para a própria manutenção diária da trabalhadora ou do trabalhador, problemática que será apresentada a seguir.

\subsection{O PARADIGMA DO TEMPO E AS FORMAS DE MENSURAÇÃO DO TRABALHO}

A relação de trabalho padrão do Direito do Trabalho, vista anteriormente, estabilizou-se em torno de um regime de horário de trabalho que também teve como base o modelo de emprego masculino, que, por estar supostamente desvinculado de quaisquer obrigações que não a obtenção do salário, poderia distribuir-se ao longo de cinco a seis dias por semana, por oito horas diárias somadas a uma ou duas horas de descanso intrajornada, excepcionados os feriados e períodos de férias, definidos pelo empregador.

Esse regime de tempo de trabalho, evidentemente, ignorou o trabalho reprodutivo, tendo sido desenvolvido para um modelo de emprego que se baseia no contrato sexual (FUDGE, 2005, p. 267). Helena Hirata e Philippe Zarifian (2009, p. 253) explicam que a noção moderna de trabalho surge da separação entre trabalho e força de trabalho, estando o tempo entre os dois, referência central para a avaliação de produtividade na relação assalariada, ao passo em que o trabalho doméstico é seu oposto, já que está ligado à afetividade e não à objetificação, sendo refratário à mensuração.

Conforme Pedro Augusto Gravatá Nicoli (2015, p. 282), “o tempo é a essência do Direito do Trabalho", uma vez que sua limitação foi seu "ato fundador". Contudo, "a determinação do tempo de trabalho baseou-se em um conceito de referencial masculino, contraposto ao tempo reprodutivo feminino" (SUPIOT et. al., 2001, cap. VI, tradução 
nossa). Tal como o modelo de trabalho, esses arranjos de tempo e jornada foram manifestadamente adotados pela maioria dos países ocidentais após a Segunda Guerra Mundial - prioritariamente nos países ricos -, mas a crescente participação das mulheres no mercado de trabalho evidenciou os problemas desse padrão semanal de 40/44 horas (FUDGE; OWNENS, 2006, p. 21).

Joanne Conhaghan (2006, p. 110) relata que o primeiro "estágio" de regulação do tempo de trabalho, considerado por muitas autoras e autores o início do Direito do Trabalho, foi a introdução de legislação protetiva que limitava as jornadas de mulheres e crianças nas fábricas na Inglaterra. Daí em diante, os regimes de horário de trabalho passaram a ser reguladas por lei, acordos coletivos, arranjos individuais ou pelo costume, determinando noções que hoje são comuns, como jornadas diárias e semanais, turnos, horas-extas, férias, descanso semanal remunerado e a lista segue (FUDGE, 2005, p. 266).

No caso do Brasil, a limitação da jornada em 8 horas diárias teve origem no Decreto $21.364 / 1932^{77} 78$, voltado à indústria, que se desdobrou em outros decretos até ser consolidado pela CLT (SOUTO MAIOR, 2017, p. 215), e veio acompanhado de previsões de jornadas reduzidas para algumas categorias - como bancários e trabalhadores de telefonia (art. 224 e art. 227 da CLT, respectivamente) -, tendo sofrido, mais recentemente, reveses históricos como a escala 12 por 36 , que pouco a pouco tem-se instalado no cotidiano das relações de trabalho brasileiras, autorizada pelo Tribunal Superior do Trabalho (TST, Súmula 444), desde que com norma coletiva, e agora pela reforma trabalhista (art. 59-A da CLT, alterado pela Lei 13.467/2017. ${ }^{79}$

A maneira como o ordenamento jurídico-trabalhista delimitou os tempos de trabalho, por mais que seja incontestável sua importância para delimitação de patamares mínimos de dignidade humana, deixa bastante evidente o sexismo imbricado nos mais basilares preceitos do Direito do Trabalho. Em normas que delimitam a "duração do trabalho normal não superior a oito horas diárias e quarenta e quatro semanais" (art. $7^{\circ}$, XIII da Constituição de 1988), com intervalos intrajornadas de no mínimo 1 hora e no máximo 2 horas (art. 71 da CLT) - considerando a regra geral -, fica visível que não

\footnotetext{
${ }^{77}$ Conforme Jorge Luiz Souto Maior (2017, p. 172), o primeiro registro de norma limitando a jornada de trabalho no Brasil foi a Lei municipal 1.350/1911 restrita ao então Distrito Federal, que determinou limite ao horário de trabalho no comércio do Rio de Janeiro em 12 horas.

${ }^{78}$ Importante mencionar, que a limitação da jornada laboral em 8 horas diárias era uma das determinações relativas à regulação do trabalho expressamente contidas no artigo 427 do Tratado de Versalhes, de 1919 (CESARINO JR, 1970, p. 72).

${ }^{79}$ Para aprofundamento, cf. SILVA, H., 2017, p. 42 ss.
} 
sobra muito tempo para encaixar as tarefas de cuidado cotidianas e, ainda menos, o cuidado de pessoas dependentes. "Ao contrário do tempo homogêneo conceituado pela Economia, as necessidades da vida em todas suas dimensões não seguem um ritmo constante" (CARRASCO; BORDERÍAS; TORNS, 2011, p. 60).

Tal como afirma Carole Pateman (1993, p. 207), a ação de "ir trabalhar" tem significados bastante diferentes para um homem ou uma mulher que saem de casa. Segundo a autora, "passar oito horas por dia em um local de trabalho e trazer um bom salário para casa é fundamental para a identidade masculina, para o conceito do que é ser homem", enquanto "uma esposa que tem um emprego remunerado nunca deixa de ser uma dona-de-casa; pelo contrário, ela se torna uma esposa que trabalha e aumenta a sua jornada de trabalho" (PATEMAN, 1993, p. 207-208).

Aliás, a dimensão quantificável do tempo é mais uma manifestação da desigualdade de gênero, visto que "ao considerar o tempo como um simples horário, estáse utilizando uma lógica de organização produtivista e masculina, sob a qual as dimensões mais qualitativas do tempo são apagadas", em particular quando relacionadas às atividades de cuidado direto (CARRASCO; BORDERÍAS; TORNS, 2011, p. 64). O tempo é medida irregular e variável, mas o Direito do Trabalho tem sido incapaz de incorporar suas diferentes dimensões. Para ilustrar, tomo o exemplo do banco de horas: o sistema parece justo se o tempo for pensado de forma linear e cronometrada, mas ignorase o fato de que determinados momentos da vida não são intercambiáveis como o banco de horas pretende, ou seja, "compensar" horas de um dia em outro pode significar experiências de vida totalmente distintas. ${ }^{80}$

Pensando na centralidade que o tempo adquire no pensamento de Karl Marx uma vez que o mais-valor, fonte do acúmulo de riqueza, surge porque os trabalhadores trabalham mais tempo que o necessário para produzir valor equivalente ao da sua força de trabalho -, David Harvey (2013, p. 138-139) fala da importância do seu controle para a exploração capitalista. Segundo ele, é em $O$ Capital que se encontra a ideia de que a manipulação social do tempo e da temporalidade são um traço fundamental do capitalismo, sendo que "a extração de tempo de trabalho excedente se torna fundamental

\footnotetext{
${ }^{80}$ A esse respeito, vale a menção ao documentário "Doméstica" (2012), dirigido por Gabriel Mascaro, em que há o perturbador relato da trabalhadora doméstica Maria das Graças Santos Almeida, que abriu mão de seu final de semana de folga para cuidar da patroa que estava doente, deixando de voltar para a casa; foi nesse mesmo final de semana que seu filho foi assassinado, fazendo com que ela perdesse a última chance de vê-lo. A compensação posterior da folga trabalhada não trará essa chance de volta.
} 
para as relações de classe", de maneira que o tempo "é socialmente construído e está continuamente sujeito a reconstruções" (HARVEY, 2013, p. 140).

$\mathrm{Na}$ entrevista realizada por mim e Fabiana Sanches Grecco com Cristina Carrasco (2017), ela nos fez atentar que foi a Revolução Industrial que tornou o tempo uma medida quantitativa, uma vez que, como descrito pela teoria marxiana, cada vez mais o tempo dentro das fábricas se converteu em dinheiro; em oposição, as pesquisas feministas descobriram, por tentativa e erro, que o tempo do trabalho doméstico não era plenamente quantificável, pois contém dimensões qualitativas. Assim, Carrasco (2017) asseverou que as "percepções de tempo são culturais, não cronológicas", havendo diferentes valores no tempo que não são possíveis de contar tal como o mercado espera.

Conaghan (2006, p. 101-102), ao refletir sobre as fronteiras conceituais e discursivas da noção de tempo de trabalho, afirma que em grande parte tal noção é produto da limitação de jornada executada pelo Direito e que a pressão econômica tem perturbado as normas convencionais que captavam a ideia de trabalho em tempo integral e de longo prazo. Ela chama a atenção para o fato de que o tempo se tornou um indicador do tipo de trabalho (CONAGHAN, 2006, p. 104), ou seja, é usado para categorizar o trabalho, se em tempo parcial, temporário, intermitente (ou "zero hora") etc. Assim, tempo e trabalho estão intimamente inter-relacionados, estando a percepção do tempo fortemente imbricada pelas relações sociais do ambiente em que se vive e trabalha (CONAGHAN, 2006, p. 105).

Por mais que, na atualidade, o tempo cronometrado seja naturalizado na experiência cotidiana, esse modo de lidar com o tempo não é a-histórico, pelo contrário, sua origem combina com a formação do sistema capitalista. Esse caminho é revelado por E. P. Thompson, no artigo Tempo, disciplina de trabalho e capitalismo industrial, publicado originalmente em 1967, em que o autor investiga a mudança do senso de tempo em relação à transição para a sociedade industrial e se questiona, desse modo, até que ponto ela afetou a disciplina de trabalho e influenciou a percepção de tempo dos trabalhadores (THOMPSON, 1998, p. 269).

Nesse caminho, Thompson (1998, p. 271-272) explica que foi no início do capitalismo industrial que houve a mudança na apreensão do tempo e ritmo de trabalho, que migrou da "orientação pelas tarefas", no qual os ritmos de trabalho acompanham as tarefas que precisam e podem ser executadas naquele dia, para o "trabalho de horário 
marcado", em que tarefas ficam sujeitas à disciplina do tempo, que por sua vez é reduzido a dinheiro. Nas suas palavras, "o tempo agora é moeda, ninguém passa o tempo e sim o gasta" (THOMPSON, 1998, p. 272).

A transição para o "trabalho de horário marcado" faz com que trabalhadoras e trabalhadores experimentem uma distinção entre seu "próprio" tempo e o tempo vendido ao empregador, enquanto este passa a "usar o tempo de sua mão-de-obra" para a produção; com isso, "o que predomina não é a tarefa, mas o valor do tempo reduzido a dinheiro" (THOMPSON, 1998, p. 272). Nesse relato, Thompson (1998, p. 271) afirma que nas comunidades em que predominava a orientação pelas tarefas, havia pouca separação entre "o trabalho" e "a vida", ou seja, entre as relações sociais e o trabalho, o que mudou com a transição para o modelo de horário marcado.

Vale dizer que o autor registrou em seu estudo o descompasso enfrentado por mulheres trabalhadoras na transição para um regime de trabalho cronometrado, devido ao tempo que dedicavam ao cuidado (THOMPSON, 1998, p. 288). Em suas palavras:

Esse ritmo só era tolerável porque parte do trabalho, com as crianças em casa, se revelava necessário e inevitável, e não uma imposição externa. Isso continua a ser verdade até os dias de hoje. (...) o ritmo do trabalho feminino em casa não se afina totalmente com a medição do relógio. A mãe de crianças pequenas tem uma percepção imperfeita do tempo e segue outros ritmos humanos. Ela ainda não abandonou de todo as convenções da sociedade 'pré-industrial' (THOMPSON, 1998, p. 288).

A partir disso, Joanne Conaghan (2006, p. 108) se pergunta quais as implicações de gênero dessas mudanças na percepção do tempo. Segundo ela, a falta de compatibilidade do tempo do cuidado com o tempo cronológico pode ajudar a explicar a dificuldade de reconhecimento desse tipo de trabalho, seja ele remunerado ou não, destacando que a análise de Thompson "aponta uma tensão entre a qualidade do cuidado e sua sujeição às disciplinas do tempo e custo", pois as expectativas sobre o cuidado são relativas à tarefas, não governadas pelo tempo (CONAGHAN, 2006, p. 108). Falta somar a esta análise, segundo a autora, que a transição para o tempo da produção capitalista só foi possível por se ancorar na divisão sexual do trabalho (CONAGHAN, 2006, p. 109).

Fazendo paralelo entre análise de Thompson e o mercado de trabalho no século XXI, especialmente no tocante à dicotomia tempo de vida e tempo de trabalho, Conaghan (2006, p. 109) afirma que embora a preocupação com a necessidade de conciliar trabalho e família esteja presente no discurso juslaboralista e nas políticas das empresas e dos 
Estados, não há um reunião entre as esferas da vida e do trabalho. Para ela, "as normas de tempo estão sendo implantadas para garantir a separação contínua entre trabalho e vida", tendo, assim, proporcionado apenas algumas adaptações, enquanto o Direito continua fazendo a mediação das demandas conflitantes de trabalhadoras e trabalhadores, de um lado, e empregadores, de outro (CONAGHAN, 2006, p. 110).

A discussão sobre tempo permite repensar a organização da vida a partir da lógica do cuidado, não da lógica do acúmulo de riqueza (do capital), o que inclui organizar o tempo a partir da atenção ao outro, não a partir das demandas da produção. A esse respeito, Marc Bessin (2016, p. 236-237) fala em "temporalidades sexuadas da atividade", que mobilizariam duas dimensões do tempo: a primeira é o tempo do relógio (cronos), dominante, que seria universal, material, racional e quantitativo, dimensão cronológica que remete a um "tempo masculino", baseado em experiências dominantes e que serve a um sistema de gestão do trabalho; a segunda, da experiência temporal das mulheres e dos subalternos (kairós), que diz respeito a uma relação com o tempo baseada na antecipação e consideração do outro, tratando-se, com isso, de uma dimensão de tempo da interação, da antecipação, da responsabilidade e do julgamento situacional, na qual é possível apreender todas as dimensões qualitativas da ação enquanto ela se passa.

Assim, o tempo cronológico não é capaz de apreender completamente a atividade do cuidado devido à sua complexidade, interpenetração de tempos públicos e privados, mobilização de dimensões subjetivas e morais na atividade profissional e a manutenção de uma vigilância permanente em si e nas pessoas do entorno, de modo que essa segunda temporalidade, descrita por Bessin (2016, p. 237), funda-se na interação com o outro, relacionada a competências socialmente designadas às mulheres. Por esse motivo, é possível vislumbrar a iniquidade no estabelecimento de políticas públicas e direitos que mobilizam tempos cronológicos idênticos para todas as pessoas, como se fosse um critério universal, democrático e igualitário (BESSIN, 2016, p. 238). ${ }^{81}$

\footnotetext{
${ }^{81}$ Bessin (2016, p. 238) ilustra essa questão das diferentes temporalidades com o exemplo das aposentadorias de homens e mulheres, pois o autor considera que o uso das idades cronológicas como parâmetro "só reforça as desigualdades de gênero, ao se consideraram as carreiras profissionais fragmentadas das mulheres". Segundo o autor, "[a] diferenciação sexuada dos calendários privados remete a essa problemática temporal generificada. $\mathrm{O}$ avanço da idade e a experiência do envelhecimento são eminentemente de gênero (diz-se que os homens amadurecem e que as mulheres envelhecem) e, tomando um aspecto ocultado pelas ciências sociais do envelhecimento, o da sexualidade, é forçoso constatar que o ponto gênero e idade estão imbricados (BESSIN, 2016, p. 238).
} 
Com efeito, Marc Bessin (2016, p. 243) afirma ter receio de uma "responsabilização individual cada vez mais sinônima de redução das proteções e exposições à precariedade, diante das evoluções atuais das políticas sociais, sob o disfarce da ativação", além de que, para o autor, "falar apenas em direitos e proteção não basta", pois eles são concebidos a partir de uma linguagem universal. Nas palavras do autor, nos momentos de restrição de direitos é "certamente fundamental defendê-los e reforçar as bases e suportes sociais", mas é também necessário "observar a incapacidade desse bem apreender as singularidades e, sobretudo, admitir que ele também produz desigualdades, especialmente de gênero (BESSIN, 2016, p. 244). O autor conclui:

Os tempos sexuados do cuidado são bastante reveladores do desafio lançado às sociedades democráticas aceitando o princípio de uma política realizada pelo privado. As análises temporais do cuidado serão inevitáveis nas discussões sobre a renovação do Estado social, tornandoo capaz de estar atento às desigualdades que ele reforça ao apoiar-se em categorias abstratas e universais (BESSIN, 2016, p. 244).

Destarte, o "tempo no trabalho de cuidado" é subjetivo, de difícil medição, por compreender "aspectos intangíveis representados pela subjetividade da própria pessoa e materializados na experiência vivida", o que Carrasco, Borderías e Torns (2011, p. 64) denominam tiempos generadores de la reproducción. As autoras apontam que uma das limitações para captação do trabalho de cuidados está relacionada com as tarefas de gestão, organização e responsabilidades que este implica, já que em casa normalmente não se atribui um tempo concreto à realização dessas tarefas, de modo que as mulheres o organizam e o gerem enquanto realizam outros trabalhos, de forma simultânea (CARRASCO; BORDERÍAS; TORNS, 2011, p. 65). Além disso, cuidar de alguém não significa apenas realizar atividades, mas é um estado mental, pressupondo responsabilidade e disponibilidade contínuas, consubstanciando mais que uma ação concreta, mas um tempo potencial de realizar certa tarefa (CARRASCO; BORDERÍAS; TORNS, 2011, p. 65).

De acordo com Maria Betânia Ávila (2016, p. 138), é a lógica do trabalho produtivo que se impõe na forma de organização do tempo social no cotidiano", fazendose necessário que as pesquisas preocupadas com o uso do tempo e sua mensuração levem em conta as diferentes temporalidades do trabalho produtivo e do trabalho reprodutivo, além de preocuparem-se em não naturalizar a "ideia de tempo social como um recurso externo ao tempo de existência das pessoas, o que pode reforçar a lógica instrumental da 
apartação entre tempo do trabalho e o tempo da vida". No caso da lógica temporal do trabalho doméstico, esta é formada "tanto por uma sequência de tarefas variadas, com ou sem interrupções, como pela realização simultânea de tarefas e ainda por tarefas cujo desenrolar segue um ritmo próprio e singular a cada momento que se realiza" (ÁVILA, 2016, p. 141).

Com essa compreensão, Judy Fudge (2005, p. 263-264) afirma que há uma anomalia social, um descompasso entre o modo como atividade produtiva e reprodução social são organizadas em sociedades de mercado, havendo uma separação entre o local de procriação e manutenção diária, que é o domicílio, e o local das relações produtivas, onde é desempenhado o trabalho assalariado. É justamente a separação entre produção e reprodução que dá origem a uma "contradição essencial nas formações sociais capitalistas", que é o conflito entre o padrão de vida das trabalhadoras e trabalhadores e o impulso à acumulação, que precisa ser mediada pelo Estado (FUDGE, 2005, p. 264).

O padrão de alocação de tempo das origens do capitalismo, forjado o modelo do homem-provedor e mulher-cuidadora, enfrentou problemas com as novas configurações do mercado de trabalho considerando o gênero, o que não significou mudanças profundas, uma vez que muitas mulheres continuam a adotar padrões de trabalho que divergem da norma tradicional de tempo integral, permitindo, com isso, que combinem o trabalho remunerado com o cuidado não remunerado, o que vem atrelado a uma maior precariedade (CONAGHAN, 2006, p. 126). Segundo Conaghan (2006, p. 127), "grande parte deste trabalho continua a ser caracterizada por salários e condições precárias e insegurança no trabalho", reforçando papéis de gênero, cada vez mais arraigados nas necessidades produtivas. Sob esse prisma,

(...) uma vez que reconhecemos a relação entre as normas do tempo de trabalho e as necessidades de cuidados neste contexto, é difícil conceber o trabalho a tempo parcial sem referência ao género. Trabalhar meio período é ter um equilíbrio diferente na alocação de tempo para o trabalho e atividades de vida do que o que é refletido na norma 'típica' em tempo integral. (...) A sujeição do trabalho à medição em unidades de tempo é um produto de necessidades particulares que surgiram no capitalismo industrial inicial e que finalmente encontraram expressão em uma ordem social de gênero que facilitou a separação do trabalho e da vida e, assim, possibilitou o capital. comprar e consumir mão-de-obra exclusivamente por tempo (CONAGHAN, 2005, p. 30) ${ }^{82}$

\footnotetext{
${ }^{82}$ Excerto original: “(...) once we recognize the relationship between working time norms and care needs in this context, it is difficult to conceive of part-time work without reference to gender. To work part-time is to strike a different balance in the allocation of time to work and life activities than is reflected in the full-time,
} 
Laís Abramo e Maria Elena Valenzuela (2016, p. 119) utilizam os conceitos de "pobreza de tempo" e "déficit de tempo" para melhor apreender a "forma através da qual a ordem de gênero perpassa o mundo do trabalho e as vinculações entre o trabalho produtivo e o reprodutivo, revelando uma parte oculta dessa equação". Considera-se, desse modo, que uma pessoa sofre de pobreza de tempo quando a soma das "horas destinadas ao trabalho remunerado, ao transporte, cuidado pessoal, produção doméstica e às necessidades fisiológicas básicas" ultrapassa as 168 horas que compõem uma semana; por conseguinte, um domicílio sofre de déficit de tempo se um de seus integrantes se enquadrar na situação anterior (ABRAMO; VALENZUELA, 2016, p. 119). Isso demonstra que "em muitos domicílios gerar renda suficiente para não ser pobre implica pagar um alto custo pessoal, que se expressa em extensas jornadas de trabalho", o que revela que "a produção doméstica e as responsabilidades de cuidado aumentam a carga de tempo e, consequentemente, limitam a disponibilidade das mulheres para o trabalho remunerado, o que conduz a um ciclo vicioso de pobreza" (ABRAMO; VALENZUELA, 2016, p. 120).

Independente de como são os arranjos entre tempo de trabalho mercantil e tempo de trabalho de cuidado - como as famílias, em especial as mulheres, alocam seu tempo para cada uma dessas esferas -, sabe-se que a articulação entre ambos constitui uma importante fonte de bem-estar ou mal-estar para as pessoas, ao mesmo tempo que gera considerável influência na desigualdade entre mulheres e homens (CARRASCO; BORDERÍAS; TORNS, 2011, p. 67). Assim, falar em igualdade exige considerar a necessidade de uma profunda reconfiguração do regime vigente de tempo, "enraizado no vínculo empregatício padrão e na divisão sexual do trabalho", bem como um comprometimento do poder público e o reconhecimento do significado social do cuidado (FUDGE, 2016, p. 21).

Logo, na concepção de Fudge (2016, p. 24), a melhor rota para isso seria a redução geral das horas de trabalho, algo como uma semana de trabalho de 30 horas sem redução salarial, ao que ela completa que por mais que a ideia possa parecer utópica, um dia a proposta de limitação diária de trabalho em oito horas também o foi. Bila Sorj

\footnotetext{
'typical' norm. (...) The subjection of work to measurement in units of time is a product of particular needs which emerged in early industrial-capitalism and which eventually found expression in a gendered social order which facilitated the separation of work and life and thereby enabled capital to purchase and consume labour on a time-exclusive basis".
} 
(2006, p. 38) alinha-se à proposta, afirmando que "a redução da jornada de trabalho, sem prejuízo do salário, poderia ser um forte incentivo para os pais assumirem integralmente as responsabilidades paternas".

Em termos jurídicos, o ideal seria fazer com que as normas relativas ao tempo de trabalho considerem de fato as responsabilidades familiares e o trabalho doméstico não remunerado desempenhado pela maioria das pessoas. Caso contrário, manter a regulação de jornadas de trabalho extensas, que tomam grande parte do dia de trabalhadoras e trabalhadores, exige a organização de arranjos privados para dar conta das necessidades familiares, afastando o modelo nacional da responsabilidade pública com o cuidado e da promoção da igualdade de gênero.

\subsection{A CARGA DE GÊNERO CONTIDA NA NOÇÃO DE SALÁRIO}

Desde a formação do sistema capitalista, como apresentado nos itens anteriores, as concepções de trabalho, trabalhador e tempo de trabalho eram padronizadas a partir de parâmetros masculinos e atreladas a arranjos familiares que despejavam sobre as mulheres as responsabilidades do cuidado. Esse padrão estendeu-se para parte do imaginário referente aos salários, que pressupunha, ao longo da formação capitalista, o sustento de uma família chefiada por um homem provedor, uma esposa dedicada exclusivamente ao cuidado não remunerado na esfera doméstica e as crianças.

Desde o final do século XVIII, o pensamento econômico associou progressivamente trabalho no mercado ao recebimento de um salário, o que contribui de maneira decisiva para a desvalorização do trabalho de cuidado (CARRASCO; BORDERÍAS; TORNS, 2011, p. 22). Disso decorreu que as mulheres que se dedicavam prioritariamente ao trabalho doméstico para suas famílias como "dependentes do provedor, já que não eram assalariadas, passando a ser contabilizadas nos censos, desde o início do século XX, como "inativas" ou "improdutivas", o que contribuiu para sua invisibilidade (CARRASCO; BORDERÍAS; TORNS, 2011, p. 23).

Silvia Federici (2017, p. 193) afirma que foi na transição para o capitalismo, período de acumulação primitiva, que a família surge como "instituição mais importante para a apropriação e para o ocultamento do trabalho das mulheres", com a distinção de 
que se "na classe alta era a propriedade que dava ao marido poder sobre sua esposa e seus filhos", foi a "exclusão das mulheres do recebimento de salário" que deu aos homens trabalhadores um poder semelhante sobre suas mulheres (FEDERICI, 2017, p. 194). Na Inglaterra do século XVII, ainda que toda a família trabalhasse na indústria artesanal doméstica, os homens casados tinham direitos legais sobre os rendimentos de sua esposa, criando condições para o que Federici (2017, p. 195) chamou de "patriarcado do salário", que diz respeito às condições materiais criadas para a sujeição das mulheres aos homens e a apropriação de seu trabalho.

Foi só a partir do século XIX que "família moderna", centrada no trabalho não remunerado executado em tempo integral pela "dona-de-casa", se generalizou entre a classe trabalhadora britânica e estadunidense, fruto do desenvolvimento das primeiras leis fabris que limitavam o emprego de mulheres e crianças, no "primeiro investimento de longo prazo da classe capitalista sobre a reprodução da força de trabalho, para além de sua expansão numérica", resultado de uma permuta "entre a garantia de maiores salários, capazes de sustentar uma esposa 'não trabalhadora', e uma taxa mais intensiva de exploração" (FEDERICI, 2017, p. 196).

A perda do valor do trabalho de cuidado das mulheres se somou a uma profusão de informações, por parte de cientistas, demógrafos, médicos etc., que certificavam o papel crucial do trabalho doméstico nos níveis de vida e bem-estar das famílias, o que abriu espaço para uma "ideologia da domesticidade" e a defesa do pagamento de um salário familiar para o homem, impondo que as mulheres permanecessem fora do mercado de trabalho e se dedicassem ao cuidado (CARRASCO; BORDERÍAS; TORNS, 2011, p. 23).

Fixando-se na história da organização da reprodução social no capitalismo, Nancy Fraser (2016, p. 103) afirma que as mudanças nesses arranjos decorrem de "lutas de fronteiras", em que atrizes e atores sociais pelejam para demarcar os limites entre economia e sociedade, produção e reprodução, trabalho e família, identificando três regimes de reprodução social-produção econômica: i) o capitalismo competitivo liberal do século XIX, no qual foi elaborado o ideal do trabalho e família como "esferas separadas"; ii) o capitalismo estatal do século XX, que internalizou a reprodução social através da provisão pública e corporativa de bem-estar social e promoveu o ideal do "salário familiar"; e o capitalismo financeiro globalizado, no qual se instala a crise do cuidado, anteriormente abordada, e as famílias de dois assalariados (two-earner families). 
Dessa forma, foi no período entre os anos 1930 e 1950 que o investimento público em reprodução social acabou por reforçar as normas de gênero, em um contexto em que a formação do Estado de Bem-Estar Social conjugava-se ao desenvolvimento do fordismo, época em que "praticamente ninguém contestava a visão de que a dignidade da classe trabalhadora requeria 'o salário familiar', tampouco a autoridade masculina na casa e um robusto senso de diferença de gênero" (FRASER, 2016, p. 111). Vale lembrar que os regimes fordistas do Norte "financiaram os direitos sociais, em parte, pela expropriação em curso da periferia" (FRASER, 2016, p. 110), mas ainda assim o modelo de salário familiar, em certa medida, foi transplantado para o Sul.

No caso brasileiro, a lógica do salário familiar foi trazida para o ordenamento jurídico de forma mais restrita, pela Lei 4.266/1963, que instituiu o "salário-família", no formato de abono familiar ${ }^{83}$, ou seja, paga-se um valor determinado de acordo com o número de filhas ou filhos até 14 anos para pessoas empregadas ou avulsas, sistema arcado pela Previdência Social - atualmente regulado pela Lei 8.213/1991. Na época de sua criação, o Ministério do Trabalho justificou a proposta da seguinte maneira:

realmente, não é possível que, no estágio da evolução social brasileira, ainda se continue a considerar o trabalhador como uma unidade isolada, sem qualquer preocupação com seu grupo familiar, desligado daqueles a que ele dá a vida, que dele unicamente dependem e aos quais ele tem o dever moral e legal de sustentar e educar (BRASIL, 1961, p. 9994).

Carole Pateman (1993, p. 204), pensando em termos da inter-relação entre trabalho remunerado e trabalho doméstico no contrato sexual, afirma que tal como “trabalhador", o "salário" é uma categoria que "depende da relação entre o mundo civil do contrato e o domínio privado da proteção", proteção que em grande parcela permanece corporificada no salário. Segundo ela, “quando os maridos se tornaram 'ganha-pão' e suas esposas se tornaram 'dependentes' econômicas, o salário se tornou salário-família”' (PATEMAN, 1993, p. 204).

Dessa maneira, na explicação de Pateman (1993, p. 205), a ideologia incutida no salário familiar é a de que o marido/pai, não a esposa/mãe, é o responsável pela subsistência da família; também decorre daí a ideia de que o salário das mulheres é um “complemento" do salário do marido. Para Fraser (1994, p. 591), o salário familiar era o centro de uma ordem de gênero atualmente em processo de desaparecimento, na qual as

${ }^{83}$ Cf.: CESARINO JR., 1970b, p. 162-163. 
pessoas deveriam estar organizadas em famílias heterossexuais e chefiadas por homens, sustentadas pelos rendimentos do trabalho masculino, a quem deveria ser pago uma quantia suficiente para sustentar a prole e a esposa, enquanto esta ficava responsável pelo trabalho doméstico não remunerado.

Com efeito, o conceito de salário familiar foi simbólico para a cultura ocidental, sintetizando a ideia de que ganhar dinheiro era tarefa para os homens, enquanto as mulheres tinham obrigações domésticas de cuidado, descritas mais frequentemente em termos morais (HIMMELWEIT, 1995, p. 7). Posteriormente, a partir da década de 1980, o modelo do salário familiar alterou-se juntamente com os contornos do sistema econômico, que se tornaria o atual capitalismo financeirizado, conforme descrito por Fraser (2016, p. 112, tradução nossa):

Globalizante e neoliberal, esse regime promove o desinvestimento estatal e corporativo do bem-estar social, ao mesmo tempo em que recruta mulheres para a força de trabalho remunerada - externalizando o trabalho de cuidado para as famílias e comunidades, enquanto diminui sua capacidade de realizá-lo. O resultado é uma nova organização de reprodução social dualizada, mercantilizada para aqueles que podem pagar por ela e privatizada para aqueles que não podem, pois algumas pessoas desta segunda categoria fornecem cuidado em troca de (baixos) salários para aquelas que estão na primeira. Enquanto isso, o duplo golpe da crítica feminista e da desindustrialização retirou definitivamente toda a credibilidade do 'salário familiar'. Esse ideal deu lugar à norma atual da 'família de dois assalariados'. ${ }^{84}$

Essa mudança de paradigma salarial instou as mulheres a mudarem seu trabalho de maneira a se assemelhar ao modelo masculino (FOLBRE, 2006, p. 183). Ainda que os homens não sejam mais os provedores do sustento familiar ${ }^{85}$, a ideia do "provedor masculino" segue forte, fazendo com que as mulheres estejam na força de trabalho remunerada em termos muito desiguais (FREDMAN, 2006, p. 200). Ademais, vale ressaltar que a maioria das mulheres pobres, em especial em países pobres, nunca

\footnotetext{
${ }^{84}$ Excerto original: "Globalizing and neoliberal, this regime promotes state and corporate disinvestment from social welfare, while recruiting women into the paid workforce-externalizing carework onto families and communities while diminishing their capacity to perform it. The result is a new, dualized organization of social reproduction, commodified for those who can pay for it and privatized for those who cannot, as some in the second category provide carework in return for (low) wages for those in the first. Meanwhile, the one-two punch of feminist critique and deindustrialization has definitively stripped 'the family wage' of all credibility. That ideal has given way to today's norm of the 'two-earner family".

${ }^{85}$ No Brasil, por exemplo, $40 \%$ dos domicílios eram chefiados por mulheres em 2015 , sendo que em $34 \%$ foi registrada a presença de um cônjuge (IPEA, 2016, p. 1). Em termos comparativos, já que ressalto aqui a diferença entre as realidades das mulheres do Norte e do Sul global, Yumi Garcia dos Santos (2008, p. 39) retrata que na França esse número era de 5,6\%, em 1999, e de 2,7\% no Japão, em 2003.
} 
puderam optar entre trabalho de cuidado e trabalho para a subsistência, precisando sempre combinar e fazer os dois - ou seja, a dicotomia trabalho/família não é uma realidade vivida da mesma forma por todas (WILLIANS, 2005, p. 197).

Além disso, importante frisar a rigorosa inter-relação entre trabalho doméstico e o pacote salarial, sendo a força de trabalho um produto conjunto do salário e do cuidado (CARRASCO; BORDERÍAS; TORNS, 2011, p. 130). O conflito entre trabalhadores assalariados e empregadores em torno de salários, jornada de trabalho e condições de trabalho é de fundamental importância para as relações de poder que intervêm no setor da reprodução social. Ainda que o incremento dos salários reais e do poder de negociação das trabalhadoras e trabalhadores assalariados não se traduza automaticamente em uma melhora geral para todas as pessoas implicadas na reprodução social, suas perdas geralmente se estendem ao conjunto da população trabalhadora e repercutem nos níveis materiais de vida (CARRASCO; BORDERÍAS; TORNS, 2011, p. 131).

Sem igualdade no âmbito da reprodução social e sem reconhecimento do trabalho de cuidado, a defasagem salarial das mulheres, devido ao tempo dedicado por elas ao cuidado, mantém o equilíbrio de poder descompensado em favor do controle masculino do trabalho doméstico, que ainda é reforçado por ideologias e leis, de maneira que políticas de igualdade salarial entre os sexos têm pouca efetividade (CARRASCO; BORDERÍAS; TORNS, 2011, p. 13).

Fudge (1996, p. 250) concorda com o diagnóstico e afirma que a legislação sobre igualdade salarial tipicamente não considera fatores como o poder de negociação coletiva de que historicamente resultaram salários mais baixos para o trabalho das mulheres, ou a dificuldade de escolarização e profissionalização de grupos específicos de mulheres. Dessa forma, essa abordagem das questões de gênero pelo Direito do Trabalho revela adotar o mesmo padrão masculino de pensar trabalho e remuneração, permitindo que apenas algumas mulheres atinjam as demandas por salários equiparados aos dos homens, mas deixa de lado as desigualdades entre trabalhadoras, que resulta em um padrão de vida mais baixo e chances mais restritas no mercado de trabalho (FUDGE, 1996, p. 250).

A ausência de políticas públicas de oferta de cuidado - ou o retrocesso delas, no caso dos países do Norte -, considerando o papel central das mulheres no processo de reprodução social da força de trabalho, central para o funcionamento do sistema econômico, faz com que a posição delas no âmbito do trabalho assalariado e na família 
tornem inadequadas as teorias que se baseiam na produtividade, qualificação e no grau de sindicalização como fatores que serviriam de base para a definição de um salário supostamente justo (CARRASCO; BORDERÍAS; TORNS, 2011, p. 132-133).

Portanto, é fundamental inserir o cuidado dentro da análise de determinação dos salários, considerando que a relação entre trabalho remunerado, trabalho doméstico e o papel do Estado na configuração e controle da reprodução social são elementos determinantes do desenvolvimento das relações de poder (CARRASCO; BORDERÍAS; TORNS, 2011, p. 141). A importância de se debater toda a carga histórica e sexista da noção de salário é não permitir um tratamento reducionista da questão pelo Direito do Trabalho, fugindo de uma defesa inócua de uma igualdade de gênero que seria baseada em cifras iguais pagas em troca da força de trabalho de mulheres e homens, o que só faz ocultar as relações externas ao mercado de trabalho, que ganham pouca atenção apesar de serem essenciais para a sua manutenção.

Diante de todo o exposto ao longo deste capítulo, foi possível enxergar que o Direito do Trabalho está sob o controle de paradigmas sexistas dominantes, o que contamina desde a raiz seus princípios e suas normas. A conclusão que se torna evidente é de que o terreno da disciplina é muito maior que as análises convencionais abordam, mas insiste-se em reforçar o padrão restrito de trabalho e excluir o cuidado das bases juslaboralistas, de modo que não é somente o conteúdo normativo que é colocado em questão pela teoria feminista, mas toda a forma como o Direito do Trabalho é apresentado e autenticado (CONAGHAN, 1999, p. 40-41).

Portanto, o passo pretendido por este capítulo foi dado, que foi reconhecer que os parâmetros da disciplina são contingentes e historicamente definidos, tornando-se evidente a importância das lentes feministas nesse processo e da incorporação do cuidado nas análises juslaboralistas. Por conta disso, o próximo capítulo será dedicado à análise da construção e concepção do cuidado no Direito do Trabalho brasileiro, o que será feito a partir do esforço de fugir do ponto de vista dominante e estritamente focadas na legislação - que são armadilha fácil para a continuidade de análises universalizantes dando espaço para narrativas marginais e incomuns no campo de estudo jurídicotrabalhista. 


\section{CAPÍTULO 3}

\section{CUIDADO NO DIREITO DO TRABALHO BRASILEIRO}

No capítulo anterior, os esforços se voltaram para analisar alguns dos principais conceitos do Direito do Trabalho, que intrinsecamente sexistas e muito distantes de considerar as cargas do cuidado na vida de trabalhadoras e trabalhadores, acabam por contaminar a estrutura da disciplina. O auxílio das teóricas feministas do Direito do Trabalho, que iniciaram essa linha de pensamento em países do Norte, foi ponto de partida para a crítica a tais facetas juslaboralistas, o que é pertinente se considerado que a origem da legislação trabalhista brasileira é derivada das obrigações assumidas no Trabalho de Versalhes ${ }^{86}$, de forma semelhante a outros países ${ }^{87}$.

No entanto, para cumprir com os objetivos da presente tese, é necessário daqui por diante trilhar passos autônomos na análise do Direito do Trabalho brasileiro a partir da perspectiva de gênero, por dois motivos essenciais: i) por mais que o ordenamento jurídico-trabalhista tenha sido espelhado na regulação do trabalho em países europeus, suas características carregam marcas históricas e sociais características e sua aplicação se dá numa realidade distante daquela vivida por países desenvolvidos; ii) são limitadas as respostas marcadamente autocentradas que juristas costumam dar a problemas diagnosticados na realidade, sem a preocupação de se atentar à voz das pessoas diretamente afetadas pelas questões trazidas à tona, oferecendo perspectivas e experiências diversas daquelas do universo jurídico.

Se a construção teórica até aqui deu pistas de que uma saída para o Direito do Trabalho seria ampliar seu enfoque para incorporar tanto o trabalho executado para o mercado quanto para a reprodução social, optei por incluir o ponto de vista de pessoas diretamente envolvidas com as reivindicações por mudanças legais em prol da igualdade de gênero e por avanços na regulação nacional acerca do trabalho doméstico e de cuidado, questionando se e como seria possível endereçar no plano jurídico as demandas dessas vozes marginais aos estudos juslaboralistas. Nessa construção, foram também

\footnotetext{
${ }^{86}$ Jorge Luiz Souto Maior (2017, p. 145) relata que, em 16 de maio de 1919, o Brasil instalou a Comissão Especial de Legislação Social, na Câmara dos Deputados, com objetivo de respeitar o compromisso de criar uma legislação social voltada às relações de trabalho assumido no Tratado de Versalhes.

${ }^{87}$ Motivo pelo qual, inclusive, a regulamentação em torno do trabalho das mulheres segue os passos das convenções da OIT já mencionadas nesta tese. Cf.: VIEIRA, 2014.
} 
ouvidas pessoas que participaram dos processos legislativos relativos aos avanços no tratamento jurídico do trabalho de cuidado, a fim de mapear como eles aconteceram, os empecilhos e os debates ali presentes, garantindo um panorama abrangente para as análises aqui aventadas.

Cabe, portanto, esclarecer que a pretensão dos próximos itens não é de proceder uma revisão exaustiva das normas trabalhistas que abordam o trabalho das mulheres, seja a regulação do emprego doméstico ou normas relativas à parentalidade. ${ }^{88} \mathrm{O}$ foco será traçar o cenário da inserção do cuidado no Direito do Trabalho brasileiro, ancorado no diálogo constante com as falas das entrevistadas e dando destaque à reconstrução das motivações e do processo legislativo - não apenas ao texto da lei -, o que permitirá o desenvolvimento da crítica ao modo de estruturação da disciplina em torno do tema. Parte de minha inquietação deriva da impressão de que a teoria do Direito do Trabalho perdeu a conexão - se é que um dia ela de fato existiu - com a realidade nacional, com poucas e louváveis exceções.

\subsection{CONSIDERAÇÕES SOBRE O TRABALHO DE CUIDADO NO BRASIL}

A realidade nacional, derivada de sua estruturação socioeconômica e de sua posição na geopolítica mundial, não permite que normas e teorias jurídicas sejam aplicadas ao Brasil sem as devidas ressalvas ou, com ainda mais rigor, sem que se proceda uma expressiva reconstrução teórica, levando em conta as peculiaridades do modelo brasileiro. Por esse motivo, ainda que as considerações teóricas elaboradas até o momento sejam predominantemente estrangeiras, fruto do maior desenvolvimento da disciplina fora do país, não bastaria para esta tese restringir-se à análise do regramento internacional ou do dever-ser do Direito do Trabalho. Por esse motivo, a incorporação de

\footnotetext{
${ }^{88}$ Esse panorama já foi elaborado em minha dissertação de mestrado, que contém a crítica ao conteúdo dos dispositivos consolidados, inclusive no sentido de frisar o sexismo explícito em artigos revogados e vigentes. Cito como exemplo a proibição do trabalho noturno das mulheres (art. 379 da CLT), que na época de sua promulgação foi justificada como uma medida para preservar a "moral da mulher" e garantir que ela estivesse em casa para cuidar da família quando o marido chegasse do trabalho. Para detalhamento de como foi o processo de gradual revogação da proibição do trabalho noturno das mulheres, descrição pormenorizada de outros dispositivos legais claramente patriarcais, como o que dava ao pai ou ao marido o poder de pleitear rescisão de contrato do trabalho de uma mulher (art. 446 da CLT), e crítica a abordagens sexistas de normas vigentes, como o art. 384 da CLT, cf.: VIEIRA, 2014.
} 
reflexões acerca da disciplina no Brasil, sua estruturação e a conjuntura do entorno são pertinentes para a elaboração das contribuições aqui almejadas.

Judy Fudge (2014, p. 2), por exemplo, fala da crise do Direito do Trabalho no mundo desenvolvido, decorrente da erosão do tipo padrão de relação de emprego, dos novos arranjos familiares e da redução da representatividade sindical somados às relações econômicas globalizadas, que enfraqueceu as normas trabalhistas e minou sua capacidade protetiva. No caso dos países em desenvolvimento, Fudge $(2014$, p. 2) afirma saber da maior dificuldade do Direito do Trabalho em fornecer uma estrutura estável de proteção social, em especial por conta dos altos índices de informalidade. Evidencia-se ser fundamental o desenvolvimento da Teoria Feminista do Direito do Trabalho a partir do Sul.

No mesmo sentido, Lucy Williams (2005, p. 213) frisa que a discussão sobre cuidado não deve se limitar aos problemas das mulheres nas nações desenvolvidas, sendo necessária uma discussão muito mais rica, que incorpore a multiplicidades de experiências de mulheres pobres em países da periferia (WILLIAMS, 2005, p. 213). Quero evitar repetir o erro de parte dos sistemas e análises jurídicas que ignoram o trabalho das mulheres pobres, tanto dentro quanto fora de casa (WILLIAMS, 2005, p. 206), tal como das mulheres originárias do Sul global.

No Brasil, a realidade da provisão de cuidado é bastante própria, por confluência de fatores históricos, territoriais e socioeconômicos. O primeiro ponto que merece destaque a esse respeito é que, diferente do que ocorre em países europeus e norteamericanos, dos quais derivam os estudos do cuidado aqui apresentados, não é possível falar em uma crise do cuidado brasileira nas mesmas proporções e com o mesmo sentido por eles retratado. Em países do Sul, cujos projetos de desenvolvimento de Estados de Bem-Estar Social não chegaram a se estruturar (LAGARDE, 2003), como é o caso do Brasil, a provisão de cuidado público nunca foi universal, de modo que a grande maioria das mulheres que exerce atividade remunerada depende de redes de apoio - mães, filhas, vizinhas, amigas - ou paga outras mulheres para assumirem o trabalho de cuidado a elas designado.

Por esse motivo, como explicou Maria Betânia Ávila (2017) em entrevista concedida a mim e à Fabiana Sanches Grecco, os retrocessos que vivemos no Brasil com 
relação, por exemplo, ao déficit de creches, não se configuram crise do cuidado da forma diagnosticada em países desenvolvidos. Ela explica:

(...) o que nós temos de crise de cuidados é uma crise estrutural para as mulheres trabalhadoras. Porque há a ausência de instrumentos públicos, uma situação de trabalho remunerado das mulheres que se precariza cada dia mais, no contexto atual. E ao se precarizar ainda mais, ela se torna mais incerta na sua extensão de tempo de trabalho e com muito mais dificuldades de contar com outras mulheres da mesma classe social, porque elas estão vivendo a mesma situação. Então, os arranjos estão mais difíceis. Para a classe média e para a alta burguesia, as soluções sempre foram dadas por meio do emprego doméstico das trabalhadoras domésticas, da requisição de uma força de trabalho que também é das mulheres (ÁVILA, 2017).

Dessa forma, com relação às atividades de cuidado remuneradas, pode haver sim uma tendência ao crescimento da demanda, derivada de fatores como a fixação da mulher no mercado de trabalho, observável nos dados sobre a expressiva ampliação da taxa de atividade feminina nas últimas décadas apresentados na Introdução desta tese, somado ao aumento do número de idosos na população brasileira, que saltou de 14,2 milhões em 2000, para 19,6 milhões em 2010, com a previsão de que em 2060 atinja 73,5 milhões de pessoas (IBGE, 2016, p. 146). Esses números devem ser considerados em conjunto, por exemplo, com o dado de que a família é o centro preferencial do cuidado no Brasil, especialmente das pessoas idosas, pois "a maior parte dos idosos reside com a família, sendo esta considerada a principal fonte provedora de cuidados" (GRATAO, 2012).

Independente da atividade de cuidado executada, desde as tarefas como babá, cuidadora de idosos, na faxina ou na cozinha, a responsabilidade pelo cuidado no país ainda recai predominantemente sobre os membros da família, em geral as mulheres, ou é redistribuída para trabalhadoras domésticas e outras profissionais do cuidado pouco valorizadas. No Brasil, a maioria das trabalhadoras do cuidado são identificadas como trabalhadoras domésticas em sentido amplo; essa percepção de que tarefas de cuidado de toda espécie são de responsabilidade de uma trabalhadora doméstica, muito raramente identificada como "cuidadora", demonstra o "escasso reconhecimento institucional de que gozam essas profissionais" (GUIMARÃES; HIRATA, SUGITA, 2012, p. 87). 
Pesquisa do IPEA (2016) revela que no país, em 2014, havia 5,9 milhões de trabalhadoras domésticas remuneradas ${ }^{89}$, o equivalente a cerca de $15 \%$ das brasileiras ocupadas, com uma marcante diferença racial: dentre as mulheres negras, $17,8 \%$ integravam a categoria ${ }^{90}$, sendo a principal ocupação entre elas; dentre as mulheres brancas, com $10 \%$ integravam a categoria - perdendo para o setor do comércio e da indústria. Segundo Heleieth Saffioti (1984, p. 48), a presença de um número tão expressivo de trabalhadoras domésticas no Brasil apresenta "um profundo significado para o padrão nacional de desenvolvimento do capitalismo, podendo servir de parâmetro para a apreciação do modelo econômico que aqui tem lugar”.

Com relação às pessoas que contratam essas trabalhadoras, Bila Sorj (2012, p. 108-109) mostra que,

(...) em média, $17,5 \%$ das famílias no Brasil têm gastos com serviços domésticos, mas esse percentual varia de $2,2 \%$, entre os mais pobres, a $51,7 \%$, no quinto mais rico. O uso de serviços domésticos é mais elevado nos quintos de renda mais ricos, sobretudo nos domicílios com filhos dependentes (até seis anos de idade).

A concentração de funções do cuidado em torno de uma única profíssão, trabalhadora doméstica, invisibiliza as cargas que recaem sobre elas, o que se agrava com ao fato de que o emprego doméstico é pouco reconhecido e pouco valorizado no mercado de trabalho do país, realidade evidenciada por diversos aspectos. Um deles é a baixa remuneração: em 2009, a remuneração média de uma trabalhadora doméstica era de $\mathrm{R} \$$ 386,45, enquanto o salário mínimo nacional era de R\$465,00 (IPEA, 2011, p. 20). Quanto ao vínculo empregatício, dentre as trabalhadoras domésticas que residiam no local de trabalho, 44,9\% tinham a carteira de trabalho assinado; já para aquelas que não residiam no local de trabalho, apenas $25,8 \%$ eram registradas; quanto às diaristas, o percentual é ainda mais baixo, de 14,8\% (IPEA, 2011, p. 15). ${ }^{91}$

\footnotetext{
${ }^{89}$ Estima-se que na América Latina existam entre 17 e 19 milhões de trabalhadoras domésticas, concentrando $15,3 \%$ do total da força de trabalho feminina da região (ABRAMO, VALENZUELA, 2016, p. 120)

${ }^{90}$ Considerando o número total de trabalhadoras domésticas, 63\% delas são mulheres negras (ÁVILA, 2016, p. 137)

${ }^{91}$ Estima-se que os números relativos à informalidade das trabalhadoras domésticas tenham aumentado após a edição da Lei Complementar 150, de 2015, que estipulou que diaristas são as trabalhadoras cuja frequência não ultrapasse duas vezes por semana, desobrigando o vínculo empregatício nestes casos.
} 
Além disso, o lugar social das trabalhadoras domésticas no Brasil, categoria historicamente segregada, deve ser compreendido a partir da especificidade da política econômica-social que marcou o país desde a regulação trabalhista, que imbricada no contexto da Era Vargas resultou na chamada "cidadania regulada" 92 (SANTOS, 1979), cujo padrão juridicamente adotado foi o do homem trabalhador industrial provedor principal da família, seguindo os países do centro (GEORGES, 2017, p. 130). Consoante Vanderlei Guilherme dos Santos (1979, p. 75), a cidadania passou a ser condicionada por um "sistema de estratificação ocupacional" definido por norma legal, o que significa que o acesso aos direitos de cidadania dependia do registro em carteira.

Por conseguinte, ao serem excluídas da CLT desde sua promulgação - nos termos do artigo $7^{\circ}$ consolidado $^{93}$-, as trabalhadoras domésticas tiveram, de certa forma, sua cidadania negada, estigma que, guardadas as devidas proporções, elas carregam até hoje. Isso fica evidente na ideia de que o registro como empregada doméstica "sujaria" a carteira de trabalho, ouvido de forma recorrente nos relatos das dirigentes sindicais quando falam da dificuldade de organizar uma categoria na qual muitas das trabalhadoras têm vergonha da profissão (ACCIARI, 2016, p. 131).

Maria Betânia Ávila (2016), refletindo sobre a revolução burguesa no Brasil ${ }^{94}$, lembra que, pela via da industrialização, o poder da burguesia nacional se consolidou por meio da dominação de classe, assentada na população negra e na opressão das mulheres. Afirma que o Brasil vive em "permanente reconstrução de uma ideologia discriminatória e de desvalorização das trabalhadoras domésticas" (ÁVILA, 2016, p. 138-139), mecanismo que encobre e justifica os nexos de exploração e dominação de raça, classe e gênero dessa relação de trabalho em distintos contextos. No trabalho doméstico remunerado, segundo a autora, "ainda estão presentes elementos servis que se chocam e contradizem os direitos formalmente conquistados" pela categoria, "estabelecendo e

\footnotetext{
92 A cidadania regulada perdeu força no Brasil desde a década de 1990, conforme Amélia Cohn (2000), e que, a partir dos anos 2000 houve uma reorganização do mundo do trabalho, despontando a figura do "empreendedorismo de si" que "ocupa o lugar deixado vazio pela perda do horizonte da inserção e da perspectiva de vida pelo trabalho assalariado" (GEORGES, 2017, P. 131).

${ }^{93}$ CLT. "Art. $7^{\mathbf{0}}$ - Os preceitos constantes da presente Consolidação, salvo quando for, em cada caso, expressamente determinado em contrário, não se aplicam: a) aos empregados domésticos, assim considerados, de um modo geral, os que prestam serviços de natureza não-econômica à pessoa ou à família, no âmbito residencial destas; (...)".

${ }^{94}$ Sobre a revolução burguesa no Brasil, elaborada a partir da crítica às tentativas de fixar um molde democrático-burguês de transformação capitalista, cf.: FERNANDEZ, 1976.
} 
preservando uma situação de forte tensionamento, cotidiano e histórico, entre servidão e cidadania" (ÁVILA, 2016, p. 139).

A autora explica que o sentido de servidão no trabalho doméstico está ligado a uma concepção sobre as mulheres e sua propensão natural e permanente de servir aos outros, que "é informado ainda por um outro sentido de servidão, que diz respeito à sua associação com a escravidão da população negra" (ÁVILA, 2016, p. 139). A autora continua, no sentido de que:

O emprego doméstico, como uma relação de trabalho, incorpora tempos históricos diferenciados. De um lado, aquele da sua inserção na esfera da cidadania como um trabalho a partir do qual se formam um campo de lutas e um sujeito coletivo já reconhecido como portador de direitos assegurados por leis vigentes no país; de outro lado, aquele que se configura pela manutenção no cotidiano de práticas de trabalho ilegais e servis. As conquistas legais, em contrapartida, devem se percebidas como um avanço e como parte do contraditório processo de democratização do país nessas últimas décadas, no qual a estratégia de luta por direitos é generalizada no Brasil e na América Latina (ÁVILA, 2016, p. 139).

A análise de Ávila é bastante cautelosa ao abordar o trabalho doméstico e a escravidão negra no Brasil, mas essencial advertir que não se pode expandir suas palavras no sentido de, inadvertidamente, traçar uma relação direta entre eles, como se o trabalho doméstico fosse uma continuidade das relações escravocratas. Regina Teodoro, em um de nossos encontros ao longo da pesquisa de campo em 2017, afirmou que as trabalhadoras domésticas estão cansadas de ouvir que o trabalho doméstico vem da escravidão. Segundo ela, esse discurso serve muito mais para reforçar a ideia de que os direitos conquistados pela categoria são "mais que suficientes", como se elas tivessem que agradecer por não serem mais tratadas como escravas e se resignar com o que elas têm.

Feitas essas considerações, passo a abordar o modo como o Direito do Trabalho brasileiro trata dois assuntos centrais quando em pauta o cuidado: responsabilidades familiares de trabalhadoras e trabalhadores, no que se incluem as previsões de folgas para cuidar da família, intervalos para amamentação, licença-maternidade e licençapaternidade e direito à creche ou locais para guarda de filhas e filhos; e direitos relacionados ao trabalho doméstico remunerado.

Por opção metodológica, o recorte desta pesquisa se inicia pela CLT e dá ênfase às principais normas em torno dos temas aqui elencados. Tais normas serviram de 
referência para orientar a pesquisa de campo, cuja finalidade era verificar se a forma como o cuidado é tratado pelo Direito do Trabalho favorece a inclusão ou exclusão das mulheres do emprego e responder se a assimilação de tarefas de cuidado pelo Direito é um caminho considerado por integrantes de organizações profissionais e do movimento feminista na busca por igualdade de gênero. O foco é registrar os embates políticos que levaram à configuração da disciplina aos moldes atuais e dar espaço às experiências de mulheres cuja voz é normalmente ignorada, e ao modo como elas articulam os direitos trabalhistas em sua realidade.

\subsection{RESPONSABILIDADES FAMILIARES}

Na regulação do trabalho, desde a década de 1930 no Brasil, a criação das crianças, atenção com a casa e cuidado geral com a família são tratados, predominantemente, como de responsabilidade das mulheres. Ademais, a maternidade, ou a potencialidade de as trabalhadoras serem mães, é uma preocupação da legislação trabalhista desde as primeiras normas votadas ao trabalho feminino ${ }^{95}$, o contrário do que acontece com a paternidade, que não foi aventada até a Constituição de 1988.

Consoante Bila Sorj (2006, p. 30), "no que se refere às medidas de conciliação entre trabalho e vida familiar, a legislação trabalhista brasileira é muito tímida, apresenta um claro viés natalista e é desigual em relação às responsabilidades esperadas de mães e pais". Dentre tais medidas encontram-se as hoje vigentes licenças maternidade e paternidade, os intervalos para amamentação, a possibilidade de folgas para cuidar de alguém da família e a provisão de creches, tema este que, para fins de organização, será apresentado em subitem específico, devido à ênfase dada ao assunto pelas feministas e estudiosas do cuidado.

Antes de partir para análise de tais medidas, é importante iniciar com uma visão mais geral sobre como as responsabilidades familiares integram o Direito do Trabalho no Brasil. Ainda que o recorte desta tese parta da CLT, promulgada em $1^{\circ}$ de maio de 1943 ,

\footnotetext{
${ }^{95}$ A problematização mais aprofundada sobre a forma mística e idealizada que predomina nas abordagens sobre maternidade, incluindo os reflexos disso na lei trabalhista, foi feita em minha dissertação de mestrado. Cf.: VIEIRA, 2014.
} 
é impossível deixar de lado a década de $1930^{96}$, uma vez que, como o próprio nome indica, a Consolidação das Leis do Trabalho não teve origem inteiramente própria, tendo sido a articulação de textos legais que vinham sendo promulgados desde a chegada de Getúlio Vargas ao poder. Vale lembrar que junto com Vargas veio a criação do Ministério do Trabalho, Indústria e Comércio e a redação de numerosos projetos de conciliação entre capital e trabalho, que eram convertidos em lei pelo poder ditatorial da época (CESARINO JÚNIOR, 1952, p. 194).

Assim, antes mesmo da nomeação dos membros que comporiam a comissão para elaboração da CLT, já existiam normas relativas ao que ficou convencionado chamar “trabalho da mulher". A primeira delas ${ }^{97}$ foi o Decreto 21.417 , de 17 de maio de 1932 , que regulou as condições de trabalho das mulheres em estabelecimentos industriais e comerciais (SOUTO MAIOR, 2017, p. 216). Dentre seus dispositivos, constavam a determinação de igualdade salarial, a vedação do trabalho noturno feminino e suas exceções, a restrição do carregamento de cargas para as mulheres, a proibição do trabalho feminino nos subterrâneos e em serviços perigosos e insalubres, as normativas referentes ao trabalho das mulheres grávidas. ${ }^{98}$ No mesmo decreto, já contavam a previsão de que "a mulher que amamentar o próprio filho terá direito a dois descansos especiais, de meia hora cada um, durante os primeiros seis meses que se seguirem ao parto" (artigo 11) e a exigência de que "estabelecimentos em que trabalhem, pelo menos, trinta mulheres" tenham local apropriado para "guarda sob vigilância e assistência aos seus filhos em período de amamentação" (artigo 12).

\footnotetext{
${ }^{96}$ Antes de 1930, vale dizer, os legisladores brasileiros faziam oposição ao trabalho remunerado das mulheres, conforme transparece discurso de Augusto de Lima, na Câmara dos Deputados, em 1918, sobre a possibilidade de se contratar trabalho feminino independente da autorização do marido: "De uma mulher que se apresenta sem assistência do marido e até talvez com oposição deste, o que se presume logo? $\mathrm{O}$ primeiro dever da mulher é estar de acordo com o seu marido em todos os casos. Em relação a esta mulher, que vai para uma fábrica, para um meio desconhecido, cujo patrão pode ter anexos ou em outras partes ou em outras indústrias que explore, a disposição é profundamente imoral" (SÜSSEKIND; LACERDA; VIANA, p. 1943, p. 331).

${ }^{97}$ Antes ainda, normativos sanitários válidos para as indústrias do Estado de São Paulo já tratavam do trabalho das mulheres, como o Código Sanitário de 1894, no qual constava a proibição do trabalho noturno de homens menores de 15 anos e de mulheres menores de 21 anos, reformado em 1918, trazendo a proibição do trabalho noturno de menores de 18 anos e de mulheres de qualquer idade (FRACCARO, 2016, p. 80).

${ }^{98}$ Vale dizer que a influência da normativa internacional é evidente: o artigo 427, item sétimo, do Tratado de Versalhes já determinava que os signatários adotassem o princípio de que homens e mulheres devem receber salários iguais por trabalho de igual valor (LEAGUE OF NATIONS, 1919); a Convenção n. 3 da OIT, de 1919, regulava o emprego de mulheres antes e depois do parto; e a Convenção n. 4 da OIT, de 1921, restringia o trabalho noturno das mulheres (ILO, s./d.).
} 
Vale mencionar a aura protecionista ${ }^{99}$ em torno da maternidade e da proteção da infância que imperou nos governos de Getúlio Vargas, o que fica evidente nos discursos do Ministro do Trabalho à época da organização da CLT, Alexandre Marcondes Filho, transmitidos via rádio na "Hora do Brasil". Em um deles, ouviu-se:

Sob este aspecto a História do Brasil se divide em dois capítulos diferentes, em que o ano de 1930 aparece como um divisor de águas. No primeiro capítulo nem se pensava no esforço e na capacidade de sacrifício que a existência exige da mulher operária. (...) Trazendo já no ventre o divino fruto, que era a razão principal do seu labor, as pobres mães passavam longas horas do seu dia em locais insalubres ou perigosos. Muitas foram vítimas de graves acidentes, de emanações tóxicas, de poeiras nocivas, de vapores venenosos, que não só lhes enfraqueciam a saúde como sacrificavam, sobretudo, o pequenino ser que ansiosamente aguardavam. (...) O advento do Sr. Getúlio Vargas transformou inteiramente o cenário, depois de 30 (MARCONDES FILHO, 1943a, p. 44-46).

Dessa maneira, quando nomeada a comissão para organização da CLT, em 1942, composta por José de Segadas Vianna, Oscar Saraiva, Luís Augusto Rego Monteiro, Dorval Lacerda e Arnaldo Lopes Süssekind, muitas das regras referentes ao trabalho das mulheres e as previsões relativas à maternidade e cuidado de recém-nascidos já estavam na lei. O que a comissão fez, nas palavras de Süssekind (1993, p. 15-16), foi sistematizar, com pequenas adaptações, as "normas de proteção individual do trabalhador, que foram, em geral, inspiradas nas convenções da OIT e na Rerum Novarum", no que se inserem os decretos legislativos de 1930 a 1934, além de compilar legislação da "véspera" sem alterações, atualizar e complementar disposições superadas ou incompletas e elaborar, de forma específica, novas normas para que o sistema como um todo funcionasse.

Contraditoriamente, na época de apresentação do anteprojeto, a comissão de elaboração da CLT relatou que "o capítulo versando os fundamentos da política de proteção ao trabalho da mulher foi inteiramente novo", resultando das exigências das Convenções Internacionais ratificadas e pela Constituição de 1937. Ainda que essa informação possa ser questionada, bastando a leitura do Decreto 21.417/1932, o que

\footnotetext{
${ }^{99}$ A propaganda governamental, aliás, era intensamente voltada para promover Vargas como o grande concessor da legislação trabalhista brasileira (SOUTO MAIOR, 2017, p. 254). No relatório da comissão para o anteprojeto da CLT, por exemplo, consta a seguinte passagem: "Uma glória rara cabe, todavia, ao Presidente Vargas: nenhum dos grandes codificadores participou do prévio processo de disseminação das leis, pois viveram apenas o período da maturidade jurídica; ao contrário do lúcido e feliz Chefe do Estado: criou ele próprio todo o nosso complexo Direito Social e assiste agora o triunfo de sua obra consolidada" (MONTEIRO et. al, 1943, p. 3).
} 
importa para o argumento aqui formulado é que tanto as proibições ao trabalho feminino quanto as disposições acerca do cuidado de crianças e de proteção à maternidade constavam sob a classificação temática do "trabalho da mulher". Logo, demandando tratamento específico, o "trabalho da mulher" apresenta-se como desviante, já que não há necessidade de normas voltadas ao "trabalho do homem".

Ademais, ainda que essa classificação não tenha sido obra da referida comissão, foi decisão de seus membros dividir o Título II do anteprojeto da CLT, intitulado previamente "Das Normas Gerais", em dois novos títulos, chamados "Das Normas Gerais de Tutela do Trabalho" e "Das Normas Especiais de Tutela do Trabalho" (MARCONDES FILHO, 1943b, p. 5), inserindo as normas relativas ao trabalho das mulheres e às responsabilidades familiares como "normas especiais", ou seja, entre aquelas que fogem do "padrão", deixando claro que a necessidade de creches e tempo de cuidado da prole eram considerados problemas exclusivos das trabalhadoras. Verifica-se o "mito da concepção imaculada", ironicamente nomeado por Judy Fudge (1996, p. 243), já que a contribuição masculina para a concepção e criação das crianças parece ser ignorada por essa organização.

Com tais considerações em perspectiva, os próximos tópicos se dedicarão ao modo como o Direito do Trabalho, da CLT em diante, tratou as responsabilidades familiares. Inspira esta investigação o fato para o qual chamam a atenção Joanne Conaghan e Kerry Rittich (2005, p. 13), de que as questões envolvendo o balanço entre família e trabalho na legislação trabalhista normalmente colocam foco nas mulheres e no desenvolvimento de mecanismos que garantam que elas possam "conciliar" trabalho remunerado e trabalho doméstico, reproduzindo a ideia de que essas preocupações são exceção, e não a regra para mais da metade da força de trabalho.

\subsubsection{Intervalos, folgas e licenças para cuidado de filhas e filhos}

De forma abreviada, desde a promulgação da CLT estão previstos para as trabalhadoras direitos relativos a dois "descansos especiais de meia hora cada um" para amamentação do filho ou filha até seis meses de idade (artigo 396) e a licença maternidade, cuja redação original dizia ser "proibido o trabalho da mulher grávida no período de seis semanas antes e seis semanas depois do parto" (artigo 392). Na verdade, 
há registros de debates sobre tais previsões desde 1917, quando a Câmara dos Deputados colocou em pauta uma série de projetos para a melhoria das condições de trabalho, incluindo do trabalho feminino, em resposta às greves do período ${ }^{100}$, que foram posteriormente incorporados ao projeto de Código do Trabalho debatido na casa (FRACCARO, 2016, p. 82).

Com relação aos intervalos especiais para aleitamento - pacificamente interpretados como pausa remunerada, não podendo ser descontados da jornada da empregada -, talvez a menção mais importante a ser feita é de que este dispositivo precisa ser considerado em combinação com os artigos que vêm logo na sua sequência, quais sejam, a previsão de que entidades públicas e particulares deveriam manter escolas maternais e jardins de infância nas zonas com maior densidade de trabalhadoras (artigo 397) e a previsão de incentivos para que empregadores mantenham creches e instituições de proteção a menores “destinados à guarda dos filhos das operárias durante o período da amamentação" (artigos 399 e 400).

Como esclarece a pesquisa de Glaucia Fraccaro (2016, p. 85), a previsão de intervalos para amamentação durante a jornada de trabalho estava, desde suas origens legislativas, vinculada à determinação do estabelecimento de creches e salas de aleitamento em fábricas com mais de dez operárias. Isso é retratado pelos protestos do relator do projeto, João Pernetta, que em 1919 afirmava que instalação desses equipamentos funcionava "contra a formação moral e afetiva da família", o que gerou a resposta do colega Maurício Lacerda, de que "a utilização dos equipamentos não era compulsória e as trabalhadoras que desejassem manter seus filhos em casa poderiam fazê-lo" (FRACCARO, 2016, p. 86-87).

A conjugação entre o direito a tais intervalos com a manutenção de locais para guarda dos filhos das trabalhadoras foi apagada com o passar do tempo, de maneira que, na prática, o que se viu foi a disposição do artigo 396 da CLT ser sumária e continuamente ignorada. Nas palavras de Cristiane Maria Sbalqueiro Lopes (2010, p. 53), "não causará surpresa a ninguém o fato de que essa norma, de uma maneira geral, simplesmente não é cumprida". A cada vez maior distância entre local de trabalho e a casa ou a creche praticamente inviabiliza que as mães exerçam seu direito a dois intervalos para amamentação de 30 minutos ao longo da jornada de trabalho, até que a

\footnotetext{
${ }^{100}$ Sobre a mobilização operária no período, cf. BATALHA, 2000. Para a participação das mulheres nas greves de 1917, cf. FRACCARO, 2017.
} 
criança complete seis meses de idade. ${ }^{101}$ Com bastante frequência o que se verificam são "arranjos" ou a indenização desses intervalos.

Homero Batista Mateus da Silva (2009, p. 182) classifica tais ações como abusos praticados pelos empregadores para "reduzirem os impactos produtivos" supostamente causados pela concessão deste direito, explicando que não está correto

(...) somar duas pausas de meia hora e conceder uma saída de uma hora mais cedo para a empregada ou uma folga por semana pelas pausas desvirtuadas. Tudo isso causa perplexidade. Maior ainda será o espanto quando o direito do trabalho encontrar a empresa que paga horas extras pela violação à pausa de amamentação. Poderíamos chamar essa pausa de especial e urgente, pois não há meio algum de substituição ao alcance dessa norma. Se acaso a lactante demonstrar em processo do trabalho ter sido impedida de amamentar, seria o caso de uma pesada indenização pecuniária e não de se discutirem horas extras, ou multa da Delegacia Regional do Trabalho. Afinal, nem mesmo a indenização pecuniária suprirá a carência nutricional.

Recentemente, a reforma trabalhista da Lei n. 13.467/2017, alterou referido artigo, inserindo a possibilidade expressa de negociação dos intervalos entre empregada e empregador. Nas palavras de Homero Batista Mateus da Silva (2017, p. 66), “o risco que se corre é estimular uma espúria monetarização dessas pausas ou seu agrupamento sob a forma de compensação de jornada, o que foge completamente à finalidade da norma". Ele completa, afirmando que "a norma deve ser destinada ao fim social para o qual foi concebida", de maneira que não se deve deixar seduzir por teses que levem a qualquer forma de banco de horas de pausa de amamentação" (SILVA, 2017, p. 66).

Em âmbito sindical, a temática parece não ter sido considerada de grande interesse, vez que pesquisa da Organização Internacional do Trabalho, publicada em 2011, mostrou que, entre as 94 unidades de negociação catalogadas, apenas 19 tratavam dessa garantia, sendo 12 no setor da indústria, cinco nos serviços e duas no comércio (OIT, 2011, p. 58). Destas, a maioria das cláusulas dispunha sobre os intervalos para aleitamento nos exatos termos da lei - só três ampliavam as garantias ${ }^{102}-$, e metade delas

\footnotetext{
${ }^{101}$ Com a ressalva de que minha intenção aqui não é de romantizar a amamentação, tampouco defender sua imperiosidade - vez que o corpo e as decisões da lactante devem ser respeitados. Apenas destaco os impedimentos para que aquelas que desejam continuar o aleitamento, seja exclusivo ou não, após o retorno ao emprego.

${ }^{102}$ Dessas três cláusulas que concediam às empregadas um pouco mais que a previsão legal, duas estipulavam dois intervalos de 45 minutos cada ao invés de 30, enquanto a outra estendia o direito até que filho completasse 12 meses (OIT, 2011, p. 59).
} 
ainda estipulava a possibilidade de os intervalos serem gozados cumulativamente no início ou fim da jornada (OIT, 2011, p. 58).

O pouco caso do Direito do Trabalho com a amamentação colide com a racionalidade da reprodução da força de trabalho. Nas palavras de Nancy Folbre (2006, p. 189), "um exemplo de serviço importante que, inclusive, poderia entrar nas contas nacionais é a amamentação, que produz um componente essencial para a produção de subsistência que é o leite materno". Assim, o impacto da invisibilidade econômica do aleitamento materno é expressivo, colocando em conflito duas racionalidades econômicas que parecem não conversar: de um lado, há uma pressão sobre as mães pelo retorno ao mercado de trabalho, inclusive pela licença maternidade de 120 dias; de outro, existem diversas campanhas do governo ${ }^{103}$ e de organizações internacionais pelo aleitamento exclusivo por seis meses, que reduziria a vulnerabilidade das crianças e, por consequência, os gastos da saúde pública.

Em se tratando do cuidado e da saúde de membros da família, aliás, vale dizer que no Brasil, até 2016, a lei não previa qualquer possibilidade de uma empregada ou empregado ausentar-se do trabalho para acompanhar filha, filho ou outro ente próximo a uma consulta médica, realização de exames ou algum tipo de tratamento hospitalar. Isso foi alterado pela Lei 13.257/2016, que inseriu no artigo 473 da CLT a possibilidade a trabalhadora ou trabalhador se ausentar do trabalho, sem prejuízo do salário, "até 2 (dois) dias para acompanhar consultas médicas e exames complementares durante o período de gravidez de sua esposa ou companheira" (inciso X) e "por 1 (um) dia por ano para acompanhar filho de até 6 (seis) anos em consulta médica" (inciso XI). Continua-se, porém, sem previsão similar para acompanhamento de reuniões e atividades escolares das crianças sob sua guarda. ${ }^{104}$

Voltando agora a atenção para as previsões da licença-maternidade e licençapaternidade, estas sim com significativas alterações desde a inicial proibição do trabalho das mulheres seis semanas antes e depois do parto, mantido seu salário integral, originalmente estipulada pela CLT, no artigo 392. Na época, a alocação deste artigo no

\footnotetext{
103 “O Ministério da Saúde recomenda a amamentação até os dois anos de idade ou mais, e que nos primeiros 6 meses, o bebê receba somente leite materno" (BRASIL, s./d.).

${ }^{104}$ Exemplo de solução interessante nesse sentido é previsão do Employment Standards Act, de Ontario no Canadá, de uma "licença para crise familiar" (family-crisis leave) de dez dias, para conferir maior flexibilidade para os trabalhadoras e trabalhadores cuidarem de demandas familiares imediatas (CANADA, 2000, item 50.1). O lado negativo da previsão é que ela não é remunerada e se aplica apenas para empresas com mais de 50 empregados (FUDGE, 2005, p. 281).
} 
capítulo relativo ao "trabalho da mulher" do texto consolidado e a ausência de previsão relativa à paternidade deixam clara que os legisladores ignoraram a responsabilidade paterna relativa ao recém-nascido - ou melhor, consideraram o papel masculino de provedor, logo, de continuar trabalhando para sustento da família ampliada, enquanto caberia à mãe o cuidado da filha ou filho nas primeiras semanas de vida.

Apesar de terem havido mudanças no conteúdo do dispositivo ao longo dos anos, com destaque para o Decreto-lei 229/1967, que passou a estipular a proibição do trabalho das gestantes quatro semanas antes e oito semanas depois do parto, a mais relevante das alterações veio com a promulgação da Constituição de 1988, na qual passaram a constar: licença à gestante de 120 dias, sem prejuízo do emprego e do salário, prevista no inciso XVIII de seu artigo $7^{\circ}$, e licença-paternidade de cinco dias, conforme inciso XIX, do artigo $7^{\circ}$, regulado pelo artigo $10, \S 1^{\circ}$ do Ato das Disposições Constitucionais Transitórias - ADCT.

Ambas as conquistas, tanto a ampliação do período da licença-maternidade, quanto a previsão da licença-paternidade tiveram grande interferência da bancada feminina da Assembleia Nacional Constituinte - ANC, composta por 26 deputadas, de diferentes origens e partidos. Desde o início de sua atuação, a bancada se uniu em torno do documento intitulado "Carta das Mulheres à Assembleia Constituinte", documento entregue pelas deputadas em sessão do dia 26 de março de 1987 a Ulysses Guimarães e aos demais deputados constituintes (BRASIL, 1987d, p. 22).

A Carta, surgida após um ano de pesquisa com mulheres de todo o país, abordou uma ampla gama de temáticas, divididas em: princípios gerais, reivindicações relativas à família, trabalho, saúde, educação e cultura, violência e questões nacionais e internacionais (CNDM, 1987). Dentre suas demandas, alinhadas ao postulado de que "a maternidade e paternidade como valores sociais fundamentais, devendo o Estado assegurar os mecanismos de seu desempenho", estavam a "licença ao pai nos períodos natal e pós-natal", a "licença especial às pessoas no momento da adoção" e o "direito do marido ou companheiro a usufruir dos benefícios previdenciários decorrentes da contribuição da esposa ou companheira” (CNDM, 1987).

Com relação à licença-maternidade de 120 dias, sem prejuízo do emprego e do salário, que constou no artigo $7^{\circ}$, inciso XVIII da Constituição de 1988 e está até hoje em vigor, seu texto na Fase A do anteprojeto do relator previa 180 dias tanto em caso de 
parto quanto de interrupção de gravidez, tendo sido apresentadas 12 emendas na Fase B e, por fim, tornando-se 120 dias na Fase C, caindo também a possibilidade de interrupção de gravidez, tendo assim seguido até sua aprovação final (BRASIL, 2014a).

Vale dizer que a resistência ao aumento da licença à gestante dos 84 dias que estavam em vigor na CLT para 120 dias adveio do empresariado. Isso se revela nas falas de defesa das deputadas constituintes, como a de Dirce Tutu Quadros, que no Jornal da Constituinte (1987b, p. 5) dedicado ao Dia Internacional das Mulheres teve de afirmar categoricamente: "eu não acredito que a indústria vai quebrar por oferecer a uma mulher 120 dias para recuperação e amamentação à criança". Em entrevista concedida a mim, a deputada constituinte Benedita da Silva (2018) confirmou a resistência inclusive dos parlamentares, que segundo ela diziam não entender o motivo de ampliar a licençamaternidade, ancorados em frases como "a minha mulher tem neném, isso não é doença”.

Com relação à licença-paternidade, os debates foram especialmente intensos. As deputadas constituintes seguiam uma postura firme com relação à defesa da licençapaternidade na Subcomissão dos Direitos dos Trabalhadores e Servidores Públicos. Na $6^{\mathrm{a}}$ reunião ordinária a referida subcomissão, em 23 de abril de 1987, a deputada Wilma Maia assumiu a palavra e afirmou que "na hora em que a paternidade também for considerada como valor social fundamental, a mulher passa a ser menos discriminada, e, com isso, também, não mais alijada do mercado de trabalho" (BRASIL, 1987a, p. 40).

Ainda que a licença-paternidade não tenha sido debatida na fase de subcomissões e comissões temáticas, foi introduzida como emenda na comissão de sistematização (BRASIL, 2014b). Na votação do anteprojeto da Constituição, foram aprovadas licenças de 120 dias para a gestante e oito dias para o pai (JORNAL DA CONSTITUINTE, 1988a), previsão esta que gerou incômodo entre os parlamentares homens, tendo gerado uma enxurrada de emendas que propunham a supressão do inciso XIX do artigo $7^{\circ}$ do texto em questão.

Quando postas em votação as emendas supressivas da licença-paternidade, no dia 11 de agosto de 1988, o que se viu, conforme manchete do Jornal da Constituinte (1988f), foi que "toda a polêmica travada em torno da emenda que fixou em oito dias, no primeiro turno, a licença-paternidade, acabou sepultada por um acordo de lideranças", deixando o assunto para ser disciplinado em lei complementar, com a solução híbrida 
negociada de constar no ADCT o período de 5 dias. O tal acordo, foi feito no meio da sessão, conforme notas taquigráficas (BRASIL, 1988, p. 12513-12514):

O SR. PRESIDENTE (Ulysses Guimarães) - Cumpro o dever de informar que existem outras emendas, que são coordenadas pela Liderança, na eventualidade de não serem aprovados esses destaques, a fim de que a licença-paternidade não se vincule aos 8 dias, e será resolvido nos termos do inciso anterior, aos que preenchem os requisitos fixados em lei. A lei é que vai determinar o numero de dias para a licença-paternidade. Esse texto não veio, mas sinto como de dever levar ao conhecimento da Casa que há esse esforço (BRASIL, 1988, p. 12513)

O SR. INOCÊNCIO OLIVEIRA (PFL-PE. Sem revisão do orador.) Sr. Presidente, Srs. Constituintes, tivemos um acordo, agora, com o Líder do PMDB, Nelson Jobim, e os demais Lideres para que fizéssemos uma fusão de emendas sobre a supressão de 8 dias, ficando apenas o princípio que seria feito agora no texto básico, para que fosse colocado nas Disposições Transitórias como 3 dias.

(Tumulto nas galerias)

O SR. PRESIDENTE (Ulysses Guimarães) - Atenção! Para que os trabalhos se desenvolvam... (Tumulto nas galerias.) Atenção! Colaborem com o andamento dos trabalhos, em benefício da Constituinte.

O SR. INOCÊNCIO OLIVEIRA - Sr. Presidente, houve, mais uma vez, agora, uma tentativa de acordo, colocando 5 dias nas Disposições Transitórias. Neste sentido, vamos aceitar, em nome do Partido da Frente Liberal, pois no texto básico ficaria apenas o princípio. Enquanto a lei não definir, serão 5 dias. Então, aceitamos esse acordo, porque é melhor aceitar o ruim do que o pior.

Logo, a "solução" encontrada pelos deputados foi literalmente postergar o debate para regulação em lei, falta de interesse legislativo que se estende até hoje, uma vez que a regulação não veio. Com isso, mesmo que prevista na Constituição no inciso seguinte da licença à gestante, a licença-paternidade acabou sem regulamentação e, por conseguinte, foi excluída de ser remunerada como benefício previdenciário. Assim, ao invés de ter um padrão semelhante ao da licença-maternidade, a licença-paternidade funciona juridicamente como um prolongamento da "falta justificada por nascimento do filho", prevista no artigo 573, III da CLT, e, consequentemente, os cinco dias de ausência do pai são arcados pelo empregador. ${ }^{105}$

\footnotetext{
${ }^{105}$ Aqui cabe uma breve anotação sobre o salário-maternidade previdenciário, que ao invés de contemplar todas as trabalhadoras, é seletivo: pago apenas para seguradas e, mesmo assim, com carência de 10 meses para as que não são empregadas, trabalhadoras avulsas e domésticas (Lei 8213/91, artigo 25).
} 
De 1988 até 2018, a licença-paternidade quedou praticamente estagnada, com exceção da prorrogação em 15 dias possível para empregados em locais que aderiram ao Programa Empresa Cidadã (Lei 11.770/2008), extensão que também está prevista para a licença-maternidade em 60 dias, mas com todas as ressalvas de ser um programa extremamente limitado, aplicável apenas a grandes empresas tributadas sobre o lucro real. Ademais, a Lei $n^{\circ}$. 12.873/2013, ampliou aos pais trabalhadores o direito ao saláriomaternidade, tanto em caso de falecimento da mãe, quanto em caso de adoção em que ele seja a parte do casal que optou por cuidar da criança, inserindo na CLT o $\S 5^{\circ}$ ao artigo 392-A e os artigos 392-B e 392-C.

Verifica-se que mesmo tendo o artigo $226, \S 5^{\circ}$ da Constituição atribuído a homens e mulheres responsabilidades iguais com relação à família, ao dispor que "os direitos e deveres referentes à sociedade conjugal são exercidos igualmente pelo homem e pela mulher", a licença-paternidade é reduzida a ponto de não permitir aos pais dedicarem-se ao cuidado das crianças recém-nascidas (VIEIRA, 2015). Assim, nas palavras de Patrícia Tuma Martins Bertolin e Fabiana Larissa Kamada (2012, p. 37) "maternidade e paternidade constaram no texto constitucional como diferentes, o que perpetua a oposição entre maternidade especificamente e o trabalho assalariado".

Destarte, a discrepância na forma de regular licença-maternidade e paternidade transpareceu o sexismo dos deputados constituintes e a dificuldade das deputadas levarem em frente suas reivindicações por um maior equilíbrio na distribuição do cuidado com as crianças pequenas. É preciso romper as barreiras que continuamente afastam os homens do seu potencial cuidador, começando pela legislação, mas cientes de que a utopia da mudança legislativa "licença parental" pode ser um começo, mas não é, nem de longe, a solução ${ }^{106}$ para a divisão sexual do trabalho impregnada nos ideais do que é ser mãe e pai. $^{107}$

\footnotetext{
${ }^{106}$ No mestrado relatei as dificuldades da Suécia em fazer com que os pais assumam de fato a metade do tempo de licença para cuidado de filhas e filhos (VIEIRA, 2014, p. 145). Judy Fudge (2005, p. 279) faz alusão a um quadro semelhante no Canadá, tendo sido constatado que as mulheres continuavam tirando a maior parte das licenças.

${ }^{107}$ Pensando nos países vizinhos, uma agenda de pesquisa é verificar a evolução da proposta uruguaia de "Sistema Nacional de Cuidados", que estipulou aumento da licença-paternidade e estabeleceu um subsídio de meio-período para o cuidado, que pode ser exercido tanto pela mãe quanto pelo pai durante os primeiros seis meses de vida da criança. Cf.: BATTHYÁNY; GENTA; PERROTTA, 2015.
} 


\subsubsection{Direito à creche}

O direito à creche ${ }^{108}$ e locais de guarda para filhas e filhos de trabalhadoras está previsto no artigo 389 e no artigo 400 da CLT. Com relação ao artigo 389, ele foi alterado uma única vez pelo Decreto-lei 229/1967, que transformou a previsão do parágrafo único, de que as empresas em que trabalhem mais de 30 mulheres devem fornecer local apropriado "onde seja permitido às empregadas guardar, sob vigilância e assistência, os seus filhos no período de amamentação", nos parágrafos $1^{\circ}$ e $2^{\circ}$, mantendo a mesma determinação anterior, mas incluindo a permissão de que essa exigência seja considerada suprida por meio de "creches distritais mantidas, diretamente ou mediante convênios, com outras entidades públicas ou privadas". Já o artigo 400, que estipula condições mínimas de funcionamento dos locais destinados à guarda dos filhos das operárias durante o aleitamento materno, como berçário e saleta de amamentação, não sofreu alteração desde 1943.

$\mathrm{Na}$ exposição de motivos do anteprojeto da CLT sobre tais dispositivos, a comissão organizadora explica que buscava-se solução ao "problema das creches", de grande repercussão na época, que estivesse em harmonia com a Conferência de Havana, de 1939, que recomendava que os recintos destinados à guarda de crianças se situassem nos centros mais populosos, de maneira a evitar que as beneficiárias tivessem que percorrer grandes distâncias (MONTEIRO et. al., 1943, p. 5). Com base nisso, a comissão pensou na opção das creches nos estabelecimentos industriais, que deveria ser um recurso excepcional quando não houvesse "abrigos infantis" nos centros residenciais (MONTEIRO et. al., 1943, p. 5).

O rumo tomado pela CLT, por óbvio, trilha o caminho indicado por Vargas sobre a temática. No discurso de Natal do ano de 1939, o então presidente declamou:

O meu Governo tem-se empenhado em garantir aos trabalhadores, aos que não dispõem de recursos acumulados e vivem do labor quotidiano, as condições de estabilidade econômica necessárias à manutenção da prole. (...) Já foi autorizado o plano de construção e instalação de cerca de cinquenta maternidades e lactários, distribuídos por todos os Estados

\footnotetext{
${ }^{108}$ Utilizo aqui a palavra "creche" por ela ter sido historicamente utilizada na luta dos movimentos de mulheres pela socialização do cuidado das crianças. No entanto, alinhada à Guita Debert (2012, p. 231), rejeito a visão da creche como depósito de crianças, para considerá-la um espaço de desenvolvimento e socialização infantil, em equiparação a termos como escola maternal, jardim de infância ou centro de educação infantil.
} 
(...). É preciso que as crianças desses colaboradores anônimos da prosperidade individual sejam devidamente amparadas e, enquanto as mães ganham o pão nas fábricas e oficinas, os filhos pequeninos estejam nas creches, recebendo, com os cuidados higiênicos necessários, alimentação sadia e adequada, e os mais crescidos estudem nos jardins de infância e escolas próprias da idade. Acredito que este desejo de melhorar a raça, de dar ao país gente forte e sadia, encontre ampla compreensão em todos os setores das atividades nacionais (VARGAS, 1939, p. 158-159).

A partir dos anos 1970, registram-se mobilizações relevantes no Brasil em torno da socialização do trabalho doméstico, pauta histórica do movimento feminista e das mulheres organizadas em sindicatos, conscientes das barreiras que os encargos reprodutivos impõem a elas na sociedade (TELES, 1999, p. 103). Nesse contexto, imperioso salientar o papel central dos movimentos de mulheres durante a Assembleia Nacional Constituinte, decisivo para a inserção na Constituição de 1988 de direitos como licença-maternidade e licença-paternidade, como apresentado no item anterior, e fundamentalmente da assistência gratuita para crianças em creches e escolas infantis.

Na já mencionada Carta das Mulheres à Assembleia Constituinte constava como pleito abraçado pela bancada feminina de "extensão do direito à creche no local de trabalho e moradia para as crianças de 0 a 6 anos, filhos de mulheres e homens trabalhadores (CNDM, 1987).

$\mathrm{Na}$ Assembleia Constituinte, tal como ocorrera nos debates sobre licençamaternidade e paternidade, a inclusão do direito à creche no texto constitucional tinha resistência por parte de alguns deputados constituintes. A esse respeito, o primeiro pronunciamento de Benedita da Silva enquanto deputada constituinte, em 19 de fevereiro de 1987, abordou o tema, com as seguintes palavras:

Não sou aqui representante pura e simplesmente da mulher, do negro e do favelado, mas tenho uma proposta (...) no sentido de que nossa sociedade esteja atenta a esses segmentos que foram e continuam sendo discriminados. Hoje, sabemos perfeitamente que nossa presença aqui, a presença da mulher, não se resume a um 'Clube da Luluzinha', mas temos questões específicas a tratar que, dentro das generalidades, têm-se perdido. (...) Neste momento, peço aos Srs. Constituintes que sejam sensíveis às reivindicações que estamos fazendo. Uma delas refere-se às creches. Queremos garantir creches para os filhos dos trabalhadores (...) (SILVA, 1988 p. 11). 
Da mesma forma como outros direitos caros às mulheres, alguns deputados apresentavam resistência à inserção do direito à creche no texto constitucional. Rebatendo a ofensiva contra o tema, na $18^{\mathrm{a}}$ reunião Extraordinária da Subcomissão dos Direitos dos Trabalhadores e Servidores Públicos, em 6 de maio de 1987, a deputada Lídice da Mata pronunciou-se no seguinte sentido:

Finalizando, quero colocar a questão do direito à creche. Alguns dizem que essa questão não é constitucional, pode ser determinada na lei ordinária etc. Acho que é fundamental que nós possamos avançar nesse sentido, na medida em que tenhamos a compreensão de que precisamos entender a necessidade da mulher como força de trabalho no País e a sua integração na produção social, precisamos criar os meios para que essa integração se dê de forma mais rápida, com a mulher tendo garantida a possibilidade de ter os seus filhos em situação de segurança e de assistência. (...) Então, há a ideia de que é preciso que seja garantido à mulher trabalhadora o direito à creche, que as empresas mantenham creches que possam garantir à trabalhadora a possibilidade de trabalhar deixando os seus filhos em segurança. Essa questão da creche diz respeito à questão do trabalho e diz respeito à questão também mais social, como nós discutimos, a intervenção do Estado nessa garantia. Mas a garantia da creche no emprego, no trabalho é essencial para nós, mesmo que ela seja num período menor do que a creche do Estado, mesmo que ela seja numa situação em que algumas empresas não ofereçam creche, não as construam para o trabalho, mas possam oferecer convênios que garantam a creche (BRASIL, 1987a, p. 234)

Essa linha de defesa estava de acordo com a proposta inicial de redação do direito à creche no anteprojeto, que continha a previsão de "garantia de assistência, pelo empregador, aos filhos e dependentes dos empregados, até 6 (seis) anos de idade, em creches e escolas maternais”. Depois de uma série de debates nas fases de comissões, já na fase de sistematização, a deputada Lídice da Mata apresentou proposta de emenda em que retirava-se a incumbência "do empregador" em fornecer creches, incluindo a palavra "gratuito", com a justificativa de "manter a coerência com os direitos sociais do trabalhador, pois cabe ao Estado a garantia de atendimento, em creches e pré-escolas, às crianças de zero até seis anos da idade" (BRASIL, 2014c, p. 80).

Com parecer positivo, a referida emenda foi aprovada e o texto votado em plenário já tinha a redação definitiva, prevendo a "assistência gratuita aos filhos e dependentes desde o nascimento até seis anos de idade em creches e pré-escolas", inserido no inciso XXV do artigo $7^{\circ}$, entre os direitos de trabalhadoras e trabalhadores urbanos e rurais. Restou também consignado no artigo 208, inciso IV da Constituição de 1988 ser dever do Estado garantir a educação infantil, por meio de creches e pré-escolas. 
Posteriormente, em decorrência da integração do setor educacional promovida pela Constituição, somada à Lei de Diretrizes e Bases da Educação (Lei 9.394/1996), a educação infantil tornou-se a primeira etapa da educação básica, contemplando crianças de zero a cinco anos, nos termos da Emenda Constitucional 53/2006 - o que alterou o inciso XXV do artigo $7^{\circ}$ da Constituição para a mesma faixa etária. Essas mudanças tiveram interferência no modo como o direito à creche é tratado, sendo considerado atualmente muito mais um direito da criança, do que como uma garantia de melhor distribuição social do cuidado no início da vida.

Com base em diversas pesquisas na área das ciências sociais, Fabiana Silva Fernandes, Nelson Gimenes e Juliana dos Reis Domingues (2017, p. 323) evidenciam que a pobreza é um obstáculo para educação das crianças, em especial entre zero e três anos, bem como que as mães com filhos pequenos fora da educação infantil enfrentam mais dificuldades para inserção no mercado de trabalho. Com base nos dados do Censo 2010, os autores revelam que apenas $31 \%$ das mulheres do Estado de São Paulo possuíam filhos matriculados em instituições de ensino infantil (FERNANDES; GIMENES; DOMINGUES, 2017, p. 327).

De acordo com Bila Sorj (2004, p. 3), conciliar vida doméstica e profissional é um desafio para mulheres, ainda mais aquelas com filhos pequenos, em especial para as mais pobres com recursos limitados para acessar formas privadas de cuidado. Sua pesquisa demonstra que o acesso a creches e pré-escolas muda a realidade das famílias: a renda per capita dos domicílios com crianças que frequentam a educação infantil é em média 50\% maior; as mães de crianças matriculadas em creches têm maior taxa de participação no mercado de trabalho; as mulheres com filhos em casa tem jornada de trabalho remunerado reduzida em uma hora e meia em comparação com as mulheres com filhos em instituições de educação infantil (SORJ, 2004, p. 50).

Nem o dispositivo constitucional, nem os artigos da CLT são efetivados no sentido de garantir a universalização das creches no Brasil. Cabe lembrar, aliás, que quanto à aplicação do artigo 384 da CLT, o próprio Ministério do Trabalho, na Portaria 3.296/1986, autoriza o "reembolso creche", opção dada à empregada de receber reembolso pelo empregador das despesas efetuadas com creches particulares, desvirtuando a previsão consolidada que visava a garantir a proximidade entre trabalhadora ou trabalhador e a criança, especialmente durante o aleitamento materno, bem como a leitura constituinte de que a creche é direito social, que deveria ser gratuito. 
A dificuldade de efetivar uma política de creches que atenta, ao menos, às mulheres de classes pobres que não possuem meios de contratar cuidado, seja em uma instituição privada ou de uma babá ou trabalhadora doméstica, foi tema da entrevista realizada com Tatau Godinho (2018), que vivenciou os esforços de aumento da rede de atendimento da educação infantil durante os governos Lula (2003-2010) e Dilma Rousseff (2011-2016). Segundo ela, especialmente neste último período, houve investimento e preocupação real de fortalecer a creche como um dos níveis importantes da educação, de modo que os limites desse avanço decorrem da dificuldade de fortalecer no país a "ideia da creche como prioridade social”. Ela deu seguimento a seu raciocínio:

Parece uma coisa boba, mas é impressionante a resistência das pessoas em entender que a creche e a jornada integral também são direitos sociais das mulheres. No sentido da maternidade como uma responsabilidade social e não só individual. Ou seja, não precisa se relacionar só como trabalhadora, mas no compartilhamento dessas responsabilidades. Mas isso tem crescido muito mais fortemente, a ideia da creche como direito da criança, a importância da educação e o comprometimento das gerações futuras. No governo isso é um discurso e uma lógica muito mais aceitável do que a questão das mulheres. E, um segundo elemento, como toda política, as prioridades reais definem orçamento. E a política de creches infantis, do ponto de vista imediato, é cara, porque demanda investimento grande, porque tem que aumentar a rede, ter uma rede integral, ter uma equivalência, professor/servidor e criança é maior a proporção do que em outros níveis de educação. $\mathrm{O}$ fato é que não conseguimos ainda; a pressão das mulheres não foi suficiente para convencer a sociedade da importância da creche (GODINHO, 2018).

A entrevistada ainda deu destaque à atuação do Ministério Público, que tem sido ator fundamental na judicialização e cobrança do direito à creche e à educação infantil dos governos municipais. Nesse quesito, a escolha de acionar como sujeito de direito dessa demanda judiciária a criança, não as mulheres ou as famílias de modo amplo, é uma estratégia política, mas revela aa dificuldade de que direitos considerados "das mulheres" sejam tomados como prioritários no cenário nacional.

Por fim, vale frisar que a dificuldade de ampliar a rede de creches, prioritariamente em horário integral e noturno, para atendimento das trabalhadoras e trabalhadores com responsabilidades familiares esbarra no corriqueiro e fácil argumento das restrições orçamentárias do supostamente inviável sistema de direitos sociais previsto na Constituição de 1988. ${ }^{109}$ Entretanto, como salienta Amélia Cohn (2000, p. 389), por

\footnotetext{
${ }^{109}$ Para problematização da noção de Constituição dirigente no caso brasileiro, cf.: BERCOVICI, 1999.
} 
mais que, no Brasil, "a questão social tem como regra de ouro a ser religiosamente respeitada o não onerar os cofres públicos", é preciso levar em conta que "qualquer padrão de solidariedade social (...) implica necessariamente um pacto distributivo de recursos", politicamente alocados e que, portanto, precisam ser questionados.

Diante do panorama apresentado, que buscou expor não apenas o modo de o Direito do Trabalho brasileiro endereçar as responsabilidades familiares, mas especialmente os processos legislativos que deram origem às disposições relativas aos intervalos para amamentação, licença-maternidade e licença-paternidade e o direito à creche, verifica-se que o modelo jurídico nacional ainda direciona o trabalho de cuidado para as mulheres. Isso exige delas maiores jornadas e cargas de trabalho, gerando desvantagens no mercado de trabalho e reforçando a desigualdade de gênero, além de se refletirem no comportamento dos empregadores, já que a separação entre as esferas do trabalho e da família os afastam de responsabilidades relativas ao cuidado, consideradas externas à produção. Vê-se, portanto, que "a discriminação promovida pelo Direito é uma das mais cruéis, por ser institucionalizada, socialmente aceita e considerada justa" (BERTOLIN; CARVALHO, 2010, p. 182).

\subsection{EMPREGO DOMÉSTICO}

Evelyn Nakano Glenn (2017, p. 17), considerando os dados globais que mostram que das 53 a 100 milhões de trabalhadoras domésticas no mundo, só 10\% seriam cobertas da mesma maneira que os outros trabalhadores pelo Direito do Trabalho vigente em seus países, sustenta a tese de que "a exclusão do trabalho de cuidado das formas modernas de proteção do trabalho se enraíza no entrecruzamento de dois sistemas de hierarquias sociais", que são o gênero e a raça.

A resistência histórica que se verifica na caraterização do trabalho doméstico remunerado como uma profissão equivalente às demais (FUDGE, 2006, p. 218) transmuta-se na dificuldade de seu enquadramento nas categorias juslaboralistas, que, conforme abordado no Capítulo 2, derivam de um modelo de trabalho que é masculino, fabril e centrado na produção direta de mercadorias. O longo trajeto de conquistas de direitos pelas trabalhadoras domésticas no Brasil é o que pretendo recontar a partir de 
agora, ciente não apenas da centralidade dessa profissão para a tese que se apresenta, mas do valor dessas trabalhadoras e da sua luta para todo o país.

Antes, entretanto, vale afastar de pronto a reiterada imagem da trabalhadora doméstica como "parte da família", argumento que permite barganhas entre empregadores e empregadas, linguagem muitas vezes aparece sedimentada mesmo ordenamento jurídico (ANDERSON, 2003, p. 112). Esse é o caso das normas de imigração do Reino Unido voltadas aos chamados "au pairs", que deixam claro que essas estrangeiras não são trabalhadoras ou empregadas da casa, com garantias básicas como o salário mínimo, mas sim que são "como membros da família na qual vivem”, recebendo algo como uma mesada em troca da "ajuda" doméstica (UNITED KINGDOM, s./d.).

A esse respeito, Bridget Anderson (2003, p. 113) afirma que o tratamento "familiar" das trabalhadoras domésticas é controverso, pois ao mesmo tempo em que, diante da informalidade, deixa-as abertas à exploração, é valorizado por muitas delas, particularmente devido ao isolamento do trabalho doméstico. A autora usa o exemplo de que algumas trabalhadoras preferem ganhar menos para trabalhar em famílias que as tratam bem para ilustrar seu argumento de que o trabalho é social, não simplesmente econômico, o que é preciso levar em conta nos debates sobre profissionalização do cuidado (ANDERSON, 2003, p. 113).

Cumpre mencionar que é falha a tentativa de aplicar ao trabalho doméstico e de cuidado os padrões de "profisssionalização" desenhados para auferir competência em trabalhos remunerados. Segundo Pascale Molinier (2017, p. 65), o trabalho de cuidado não é especializado, pois todo mundo pode fazê-lo - e esse é o fundamento que justifica as reivindicações para que homens e mulheres dividam a execução de tais tarefas -, mas ele acumula experiência, opondo-se a uma visão de controle, segmentação e individualização das competências para privilegiar os esforços coletivos e o afeto.

Logo, nenhum dos dois esforços serão empreendidos por esta tese, que visa a se afastar por completo de argumentos que julgam o trabalho pela suposta especialização e profissionalização, bem como a rechaçar argumentos que aproximem e relativizem a relação de emprego por uma suposta "proximidade", uma vez que as famílias empregados não confundem os laços familiares em momentos como pagamento de plano de saúde ou 
mesmo partilha de bens ${ }^{110}$. Além de que, a prática de "pegar uma menina para criar" e explorá-la como trabalhadora doméstica precisa ser definitivamente extirpada da realidade nacional ${ }^{111}$.

\subsubsection{A exclusão do emprego doméstico da CLT e a Lei 5.859/1972}

A exclusão das trabalhadoras domésticas da proteção conferida pela CLT foi explicitamente determinada desde a sua promulgação, consoante alínea "a" do artigo $7^{\circ}$, em que se determina que "os preceitos constantes da presente Consolidação" não se aplicam "aos empregados domésticos, assim considerados, de um modo geral, os que prestam serviços de natureza não-econômica à pessoa ou à família, no âmbito residencial destas".

De acordo com Arnaldo Süssekind (1993, p. 17), diferente da maioria dos dispositivos que provinham de leis e decretos já em vigor desde 1930, que foram incorporados sem grandes ajustes à CLT, o Título I - Introdução foi redigido por Dorval Lacerda e por ele próprio. $\mathrm{Na}$ exposição de motivos apresentada pela comissão organizadora na ocasião da publicação do anteprojeto da CLT, constava a seguinte explicação:

(...) fixou-se na introdução o campo de aplicação da Consolidação, a qual, justamente por derivar de uma coordenação das normas vigentes, não compreender os empregados domésticos (...). No caso do serviço doméstico, a impraticabilidade do decreto-lei n. 3.078, de 27 de fevereiro de 1941, foi um manifesto impedimento à sua pronta regulamentação, permanecendo sem valia os seus dispositivos. A vida familiar apresenta aspectos de nenhuma similaridade com as atividades econômicas em geral, nem mesmo as de beneficência. Estender-lhe o plano de uma legislação feita e adequada a outras condições pessoais e ambientes seria forçar a realidade das coisas. Uma lei especial em que

\footnotetext{
${ }^{110}$ A respeito do discurso familialista, o modo como ele atua nas negociações entre empregadores e trabalhadoras domésticas e sua articulação com o Direito, ver: YOUNES; MOLINIER, 2017

${ }^{111}$ Essa é a história de algumas das entrevistadas desta pesquisa. Creuza relatou que antes de completar dez anos, sua mão a selecionou entre os irmãos para trabalhar como babá na casa de uma família que vivia em outra cidade: "Era uma criança cuidando de outra criança. Eu cuidava dessa criança, lavava os pratos, tanto que eu era tão pequeninha que tinha que colocar o banquinho na pia para poder lavar os pratos. Eu não queria ter saído de perto dos meus irmãos e de minha mãe, eu fazia xixi na cama, queria voltar para casa e a minha patroa me botava para lavar a roupa de cama que eu sujava" (OLIVEIRA, 2016). A história de Eliete, contada por sua filha na ocasião da entrega da Medalha Laudelina de Campos Melo, dia 27 de abril de 2018, é parecida, pois aos 13 anos ela foi "dada a uma família" para trabalhar no serviço doméstico. Sobre a magnitude do problema, que em pleno século XXI estima-se que atinge 250 mil crianças e adolescentes no Brasil, cf.: SAKAMOTO, 2013.
} 
se favorecessem os benefícios da previdência social, talvez seria o melhor passo inicial de amparo a essa humilde e preciosa classe de trabalhadores (MONTEIRO et. al., 1943, p. 3).

Como mencionado pela comissão, o anterior Decreto-lei 3.078/1941, que estipulava uma série de direitos à empregada doméstica, incluindo a exigência do registro em carteira de trabalho, nunca foi aplicado, o que se deveu por, mais uma vez, falta de interesse político, pois a norma expressamente impunha, para sua efetiva vigência, a necessidade de regulamentação inferior, nos termos de seu artigo $15^{112}$, que jamais foi realizada. Nas palavras de Mauricio Godinho Delgado (2017, p. 380), “a categoria permaneceu, assim, por extenso período, em constrangedor limbo jurídico, sem direito sequer a salario mínimo e reconhecimento previdenciário do tempo de serviço".

Somente três décadas depois esse quadro teve alguma alteração, com a edição da Lei 5.859/1972, que conferiu às trabalhadoras domésticas "o mínimo de cidadania jurídica", mas que na prática acabou por formalizar a exclusão da categoria "ao não estender inúmeros direitos trabalhistas clássicos" (DELGADO, 2017, p. 420). Constava na lei, por exemplo, a necessidade de assinatura da Carteira de Trabalho e Previdência Social (artigo $2^{\circ}$ ) e o direito a férias anuais remuneradas de 20 dias úteis (artigo $3^{\circ}$ ) e inserção na Previdência Social como segurados obrigatórios (artigo $4^{\circ}$ ), mas não havia menção a importantes direitos trabalhistas, como salário mínimo, o descanso semanal remunerado e Fundo de Garantia por Tempo de Serviço.

\subsubsection{Debates constituintes e os direitos das domésticas na Constituição de 1988}

Foi apenas na Assembleia Nacional Constituinte que os debates sobre a necessidade de ampliação dos direitos das trabalhadoras domésticas ganhou campo durante todo esse intervalo, houve apenas a concessão de vale-transporte pela Lei 7.418/1985, que foi expressamente aplicada à categoria pela regulação do Decreto 95.247/1987. Desse modo, no final da década de 1980 permaneciam incipientes os

\footnotetext{
${ }^{112}$ Decreto-lei 3.078/1941. “Art. 15. O Ministério do Trabalho, Indústria e Comércio, com colaboração do da Justiça e Negócios Interiores, expedirá, dentro de 90 dias, o regulamento para a execução deste decretolei".
} 
direitos da categoria, que se mobilizou intensamente para que a Constituição democrática mudasse tal realidade.

A demanda inicialmente colocada na Constituinte era de equiparar os direitos das trabalhadoras domésticas, de modo que a CLT passasse a ser aplicada também a elas. $\mathrm{Na}$ Carta das Mulheres à Assembleia Constituinte constava o pleito por "extensão dos direitos trabalhistas e previdenciários de forma plena às empregadas domésticas e às trabalhadoras rurais" (CNDM, 1987), além de diversas sugestões e pleitos nesse sentido chegaram à Subcomissão dos Negros, Populações Indígenas, Pessoas Deficientes e Minorias. Destaco o Dossiê Mulheres Negras, encaminhado pelo Conselho Estadual da Condição Feminina do Governo do Estado de São Paulo e Comissão para Assuntos da Mulher Negra, no qual se questionava o fato de as empregadas domesticas não terem o mesmo "estatuto" que os demais trabalhadores, bem como as Resoluções da Convenção Nacional "O Negro e a Constituinte", encaminhadas pelo Centro de Estudos AfroBrasileiros, que continham a demanda do reconhecimento da profissão de empregada doméstica e diarista e seu enquadramento na CLT (SANTOS, 2015, p. 126).

Uma atriz-chave neste processo foi a deputada constituinte Benedita da Silva, lembrada, na maioria das entrevistas com trabalhadoras domésticas mobilizadas, como a pessoa que abriu as portas do Congresso Nacional e trabalhou em conjunto com o movimento organizado para que as pautas relativas ao trabalho doméstico fossem ouvidas $^{113}$. Sobre a centralidade dessa personagem, há registro da seguinte fala de Creuza Maria de Oliveira, atual secretária-geral da FENATRAD, na Oficina Nacional das Trabalhadoras Domésticas realizada em Brasília, em 2009:

Queriam nos impedir de entrar no Parlamento pra falar com Ulysses Guimarães. Se não fosse a nossa grande parceira Benedita da Silva, a gente não tinha entrado. Eu lembro de Amália, de Recife, queria ir pro braço, quebrar o vidro, porque fecharam as portas, colocaram seguranças. [...] Chegou nos tapetes vermelhos a gente acampou. E foi uma das maiores categorias [...] e os meios de comunicação não noticiaram essas coisas, as nossas idas e vindas pra conseguir que na Constituição Federal a gente conquistasse os direitos. Quando o presidente da Câmara nos recebeu, ele veio com o discurso de que ele tinha uma trabalhadora doméstica, com mais de 30 anos na casa dele e que era como se fosse da família. Eu lembro que a companheira Lenira [...] quando pegou o microfone, disse a ele 'Nós não queremos ser da família. Nós queremos que o senhor reconheça o nosso valor. Na hora

\footnotetext{
${ }^{113}$ A título de registro informal, interessante notar que na leitura das Atas das Subcomissões integradas por Benedita da Silva, vez ou outra encontra-se adendo de algum deputado aliado justificando sua ausência em decorrência de ela ter ido acompanhar a delegação de trabalhadoras domésticas em outra sessão.
} 
de votar nos nossos direitos, levante o crachá a favor' (SANTOS, 2010, p. 4)

A entrevista com Benedita da Silva foi muito esclarecedora sobre esse período de mobilização central na história de concessão de direitos para as trabalhadoras domésticas. Ela relatou o seguinte:

Em um primeiro momento se dizia que a empregada não teria nenhum direito, que não era matéria para Constituição, que aquilo era matéria para projeto de lei. E nós dizíamos que não, que se não tivesse na Constituição brasileira o reconhecimento da trabalhadora doméstica, não se conseguiria colocar uma lei. Primeiro porque não tinha uma trabalhadora doméstica aqui [na Câmara], eu estava chegando naquele momento. Majoritariamente, aqui, tinham representações dos patrões e não das trabalhadoras domésticas. Só patrões. Além disso, tem uma cultura em relação à trabalhadora doméstica, que é aquela da família que não garante direitos. (...) Juntamos todos esses componentes e falamos 'não, vamos colocar politicamente aqui e depois vamos tratar do projeto de lei para regulamentar'. Mas tem que ficar alguma coisa aqui! Então foi feita essa mobilização (SILVA, B., 2018).

A deputada contou que as trabalhadoras domésticas organizadas reuniram-se por todo o Brasil e fizeram "uma série de idas e vindas" para Brasília, tendo apoio de suas associações e das Igrejas, em especial da Igreja Católica, que auxiliaram para que elas pudessem acompanhar as votações. "E algumas dormiram na minha casa, no chão, botamos colchonete. Porque eu disse que tinha que ficar alguém para gritar na galeria e ir pra sessão" (SILVA, B., 2018).

Com a mobilização intensa e cerca de 300 representantes da categoria ali presentes (SANTOS, 2010, p. 4), as trabalhadoras domésticas conseguiram espaço em audiências públicas de duas subcomissões constituintes, ambas no dia 5 de maio de 1987. Na Subcomissão dos Direitos dos Trabalhadores e Servidores Públicos, Lenira de Carvalho, que deu início à organização de trabalhadoras domésticas no Recife, teve a palavra como representante nacional da categoria. Assim foi seu pronunciamento:

Digo às companheiras que aqui estão que temos que aproveitar esta oportunidade de falar para os poucos Constituintes presentes que temos consciência de que eles aqui estão, porque o povo aqui os colocou. É por isso que vimos, hoje, cobrar, como todos os trabalhadores estão cobrando, porque nós, domésticas, também votamos. Trabalhamos e fazemos parte deste País, muito embora não queiram reconhecer o nosso trabalho, porque não rendemos e não produzimos. Mas, estamos conscientes de que produzimos e produzimos muito. E achamos que, numa hora em que há 
uma Constituinte, uma nova Constituição para fazer, acreditamos, temos a esperança de que vamos fazer parte dessa Constituição. Não acreditamos que façam uma nova Constituição sem que seja reconhecido o direito de 3 milhões de trabalhadores deste País. Se isso acontecer, achamos que, no Brasil, não há nada de democracia, porque deixam milhares de mulheres no esquecimento. E nós servimos a quem? Servimos aos Deputados, Senadores, ao Presidente e a todas as pessoas. Estamos confiantes e, por isso, viemos aqui. Queremos dizer aos Srs. Constituintes que não foi fácil isso. Viemos do Nordeste, três dias de viagem, passando fome e com todas as dificuldades, mas, porque confiamos, primeiro, na nossa luta e, depois, em V. Exas., estamos certas disto (BRASIL, 1987c, p. 112).

$\mathrm{Na} 11^{\mathrm{a}}$ reunião da Subcomissão dos Negros, Populações Indígenas, Pessoas Deficientes e Minorias, foi Nair Jane, integrante da organização de trabalhadoras domésticas da Baixada Fluminense, quem teve a palavra:

Sr. Presidente, Sras. e Srs. Constituintes e demais componentes deste plenário: Nós, empregados domésticos, também tiramos o nosso documento e estamos a visitar as Subcomissões na esperança de que nossas reivindicações possam encontrar eco e que, assim, a nossa categoria seja inserida na nova Constituição, pois, como já disse uma companheira, se não for nesta Constituição não será em outra, porque esta é a Constituição do povo, é a Constituição do pobre - é o que dizem - nós acreditamos muito pouco que isto seja verdade, mas vamos lutar (BRASIL, 1987b, p. 162)

Em ambas as subcomissões, após as falas iniciais acima transcritas, as representantes das trabalhadoras domésticas entregaram e leram aos deputados constituintes o documento elaborado por 23 associações de trabalhadoras domésticas, de nove Estados do Brasil, reunidas em Nova Iguaçu nos dias 18 e 19 de abril de 1987. O conteúdo do documento era o seguinte:

Exmos. Srs. Deputados e Senadores Federais Constituintes:

Nós, trabalhadoras, empregadas domésticas, somos a categoria mais numerosa de mulheres que trabalham neste País, cerca de um quarto da mão-de-obra feminina, segundo os dados do $\mathrm{V}$ Congresso de Empregadas Domésticas, de 1985, realizado em Olinda, Pernambuco. Fala-se muito que os trabalhadores, empregados domésticos, não produzem lucros, como se lucro fosse algo que se expressasse apenas e tão-somente em forma monetária. Nós produzimos saúde, limpeza, boa alimentação, e segurança para milhões de pessoas; nós, sem termos acesso à instrução à cultura, em muitos e muitos casos, garantimos a educação dos filhos dos patrões. Queremos ser reconhecidas como categoria profissional de trabalhadores empregados domésticos e termos direito de sindicalização, com autonomia sindical. Reivindicamos o salário mínimo nacional real; jornada de 48 horas semanais; descanso semanal remunerado; $13^{\circ}$ salário; estabilidade após dez anos de serviço 
ou fundo de garantia e demais direitos trabalhistas consolidados; extensão de forma plena aos trabalhadores empregados domésticos dos direitos previdenciários consolidados; proibição da exploração do trabalho do menor, como pretexto de criação e educação, que o menor seja respeitado em sua integridade física, moral e mental.

Entendemos que toda pessoa que exerce um trabalho remunerado, e de vivi, é trabalhador, e, consequentemente, está submetido às leis trabalhistas e previdenciárias consolidadas.

Como cidadãs e cidadão, que somos, uma vez que exercemos o direito de cidadania através do voto direto, queremos os nossos direitos assegurados na nova Constituição (BRASIL, 1987b, p. 162)

A respeito da tramitação da proposta e o caminho até a redação final do parágrafo único do artigo $7^{\circ}$ da Constituição ${ }^{114}$, Benedita da Silva afirma que não foi fácil, mas que, ao final, elas conseguiram alguns direitos e, em especial, "deixamos a semente plantada na Constituinte: é reconhecido o trabalho da doméstica, ela tem direito de descanso, ao FGTS, ao décimo terceiro". Sobre o processo de negociação do parágrafo único e de quais incisos estariam ali inseridos, a deputada narrou que

(...) a proposta inicial que tínhamos em relação à trabalhadora doméstica era que ela tivesse os mesmos direitos dos demais trabalhadores: CLT, pronto e acabou. Os argumentos foram que o empregador não era uma empresa, que o empregador não era uma fábrica. Aí começaram: e vai ter desconto para o empregador, se ele gastar? Foi um debate de rico, porque ali também se juntaram as contradições existentes. Não só da questão do trabalho, mas da visão que se tinha, que era altamente utilitarista e possessiva do trabalhador e da trabalhadora doméstica. A ideia de "isso é meu". Isso é meu, mas eu dou comida para ela, ela dorme na minha casa. Mas ela dorme na casa porque o empregador precisa que ela durma! E ela come na casa porque, segundo a lei, você pode comer da comida que você faz! Porque não é possível você trabalhar o dia inteiro numa casa e não ter seu tíquete refeição, que seria o direito de comer. Então essas discussões foram importantes e, depois, a conclusão era a de que não iria passar nada. Ou a gente ia por ali ou então não iria passar nada. E tudo o que eu fiz foi conversando com elas, com as que ficaram. (...) E cada coisa que eu pedia, elas não queriam negociar. E elas diziam "não, a gente não aceita negociação". E aí a gente ia para uma sala, conversávamos, aí voltávamos pra lá [plenário] e eu dizia "não, não aceito". Fomos até que chegamos a uma conclusão: vamos colocar esses direitos e vamos regulamentar no projeto de lei. E na regulamentação nós poderíamos andar (SILVA, B., 2018).

\footnotetext{
114 “Art. $7^{\circ}$. (...) Parágrafo único. São assegurados à categoria dos trabalhadores domésticos os direitos previstos nos incisos IV, VI, VIII, XV, XVII, XVIII, XIX, XXI e XXIV, bem como a sua integração à previdência social".
} 
Dessa forma, as negociações foram no sentido de que, por mais que o trabalho doméstico não fosse equiparado ao trabalho urbano e rural e inserido no caput do artigo $7^{\circ}$ da Constituição, ele restaria consignado em seu parágrafo único, com a seguinte redação: "São assegurados à categoria dos trabalhadores domésticos os direitos previstos nos incisos IV, VI, VIII, XV, XVII, XVIII, XIX, XXI e XXIV, bem como a sua integração à previdência social”. Por conseguinte, elas garantiram o direito ao salário mínimo ${ }^{115}$, irredutibilidade do salário, $13^{\circ}$ salário, repouso semanal remunerado, férias anuais remuneradas com um terço a mais que salário normal, licença-maternidade, licença-paternidade, aviso-prévio proporcional ao tempo de serviço e aposentadoria. Ainda assim, a Constituição as manteve como uma categoria profissional à parte.

\subsubsection{Passos até a Emenda Constitucional 72/2013}

As conquistas consignadas na Constituição de 1988 ficaram aquém das demandas das trabalhadoras domésticas, até porque o texto aprovado acabou por mantêlas como categoria profissional apartada das demais. Por essa razão, as mobilizações dessas trabalhadoras não cessaram e, aliás, elas passaram a se organizar em sindicatos para pleitear a aplicação e ampliação de seus direitos.

A primeira mobilização de grande relevância deu-se em torno da extensão do Fundo de Garantia por Tempo de Serviço - FGTS para as trabalhadoras domésticas, o que foi previsto como ato voluntário do empregador. Editado primeiramente como a Medida Provisória 1.986/1999 com algumas reedições, foi convertida posteriormente na Lei 10.208/2001 (DELGADO, 2017, p. 421). Na época, tramitavam também outras propostas

\footnotetext{
${ }^{115}$ Com relação à demora para que se garantisse salário mínimo para as trabalhadoras domésticas, chama a atenção a seguinte narrativa a partir dos Estados Unidos: em 11 de julho de 2007, a Suprema Corte, no caso Long Island Care at Home vs. Coke, decidiu de forma unânime que as regras do US Department of Labor tinham força de lei e que, consequentemente, cuidadoras do sexo feminino empregadas por organizações privadas não tinham direito nem ao salário mínimo, nem a horas extras. Com este julgamento, segundo Glenn (2017, p. 26), a Suprema Corte determinou que "o pesado fardo de fornecer cuidado acessível aos membros mais vulneráveis da população continuaria a ser suportado não pelo Estado, pelo governo federal ou por corporações, mas pelos mais pobres e os mais desfavorecidos da população". Ao recusar-se a limitar as horas de trabalho, a Corte reafirmou também o estatuto inferior dos empregados domésticos e protegeu o direito dos empregadores de beneficiarem dos seus serviços como se tivessem direitos de propriedade sobre eles (GLENN, 2017, p. 26). Só em 2013 houve mudança na lei pelo Departamento de Trabalho, depois de mobilizações nacionais, e garantias básicas passaram a ser aplicadas às trabalhadoras do cuidado, como hora-extra e salario mínimo.
} 
relativas à obrigatoriedade do FGTS para trabalhadoras domésticas, em torno das quais a pressão da categoria chegou até Brasília. Regina Teodoro (2017) contou em entrevista:

[Minha primeira ida] Para Brasília foi o FGTS da Benedita. Não lembro direito a data. Para lei mesmo, era essa do FGTS. A gente foi no dia da votação, a gente foi barrado de entrar, era em outro modelo o Congresso. Por exemplo, eu fui de calça comprida, não podia entrar assim, alguém me arrumou uma saia (...). Estávamos em cem pessoas, barraram nossa entrada e aí veio o Luciano Zica, veio Paulo Paim, veio Carlos Santana, que eram deputados das nossas regiões. O Zica daqui, o Paim do Sul e o Carlos Santana do Rio de Janeiro. Cada deputado de uma região representada ali foi lá e botou todas nós para dentro. Lá dentro eles estavam enrolando para votar, mas tinha um grupo muito grande de domésticas uniformizadas. E acabou sendo aprovado quase que com unanimidade. Essa foi a minha primeira participação.

Outro passo legislativo foi a Lei 11.324/2006, que fez nova extensão de direitos trabalhistas para a categoria: descanso remunerado nos feriados (artigo $9^{\circ}$ ), 30 dias corridos de férias (artigos $4^{\circ}$ e $5^{\circ}$ ), estabilidade para gestante desde a confirmação da gravidez até cinco meses após o parto (artigo $4^{\circ}$ ), além de ratificar a vedação de que fossem efetuados descontos salariais por fornecimento de alimentação, vestuário, higiene ou moradia - o que já era aplicado por interpretação jurídica (DELGADO, 2017, p. 422). Ademais, o artigo $1^{\circ}$ da lei sedimentou a previsão da Medida Provisória 284/2006, que criou incentivo fiscal para o empregador doméstico, permitindo a ele deduzir do imposto de renda as contribuições previdenciárias patronais mensais relativas à empregada doméstica, até o ano-exercício de 2012 (DELGADO, 2017, p. 422).

Tatau Godinho (2018), durante nossa conversa, procedeu à reconstrução do contexto dessa mudança legislativa. No começo do governo Lula ela trabalhava em uma subárea da Secretaria de Planejamento e disse que o tema do trabalho doméstico foi colocado como importante desde o começo da gestão, o que pode ser demonstrado pela criação do Programa Trabalho Doméstico Cidadão ${ }^{116} 117$, em parceria com a OIT e a FENATRAD. Posteriormente, foi editada

\footnotetext{
${ }^{116}$ Sobre a experiência da aplicação do projeto em Campinas, Regina Teodoro (2018) diz o seguinte: “(...) a gente teve um avanço maravilhoso! Como elas tinham que ter no mínimo até a quarta série, e a gente tinha doméstica que não tinha nem isso, o que fizemos em Campinas? Fizemos elas fazerem a prova do EJA, elas fizeram, passaram, e essas mesmas mulheres que não tinham nem o terceiro ano, duas delas conseguiram entrar na universidade. Para algumas deu certo, mas outras foram dispensadas. Porque quando a patroa ficava sabendo, falava 'Ah, vocês estão fazendo esse estudozinho aí do sindicato? Isso não vai valer de nada, é só perda de tempo'. Está é uma experiência nossa, quando a trabalhadora entra na faculdade no mesmo nível do filho dela e vai fazer gastronomia, porque ela cozinhava muito bem, a patroa fala que não
} 
(...) a MP 284, de 2006, que foi aquela que estabeleceu como incentivo para registrar as trabalhadoras domésticas o desconto do imposto de renda. Ela começa como MP e em 2006 vira lei, dentro de uma mudança da legislação das domésticas que é bastante significativa. O problema é que com a legislação depois de 2013, a 'turma' esquece esses passos anteriores. Porque esse anterior equiparou o direito de férias. Tem uma questão que eu acho absolutamente definitiva que é proibir o pagamento em espécie, de não poder descontar mais por alimento, moradia, esses coisas. Regulamentou a questão do FGTS voluntário. Então, essa primeira lei foi bem importante e começou a ser discutida em 2004, para chegar no Congresso em 2006. Tem desde o começo esse aspecto (GODINHO, 2018).

Seguindo nessa toada, Tatau relata que, em 2008, o governo criou um grupo de trabalho pra discutir a mudança de legislação do trabalho doméstico, junto com vários ministérios, que foi somada a uma segunda estratégia negociada entre governo e OIT, no sentido de fortalecer a participação das trabalhadoras domésticas brasileiras na Conferência da organização que abordaria a temática. Por conta do investimento governamental nessa articulação internacional, segundo a entrevistada, o debate sobre a mudança na legislação interna ficou parado, até que teve início a tramitação da Proposta de Emenda à Constituição 478/2010.

Os debates em torno do que ficou conhecido como PEC das Domésticas tinham como interlocutores o governo; os sindicatos de trabalhadoras domésticas e a FENATRAD; as parlamentares mulheres, com destaque para Benedita da Silva; e os líderes das bancadas (GODINHO, 2018). A proposta de redação inicial da PEC era de revogação do parágrafo único do artigo $7^{\circ}$ da Constituição, de maneira a "estabelecer a igualdade de direitos trabalhistas entre os empregados domésticos e os demais trabalhadores urbanos e rurais", nos termos do projeto apresentado à Câmara dos Deputados.

precisa de uma chefa de cozinha, que quer uma empregada, e dispensa ela. Então, não é qualificação que falta para que nossos direitos sejam garantidos, para que a gente esteja dentro da CLT, a realidade é que a sociedade não consegue aceitar, é o resquício da escravidão, então eles não querem ninguém qualificado pra isso" (TEODORO, 2017).

${ }^{117}$ Interessante notar como as histórias se cruzam, pois a atual presidenta da FENATRAD, Luiza Pereira, contou na entrevista a mim concedida que o braço desse programa no Recife permitiu que ela voltasse a estudar, num momento difícil da vida dela, e fez com que ela se aproximasse do sindicato. "Meu interesse maior era a elevação da escolaridade. Então fiz, completei o ensino fundamental na modalidade EJA e depois fui para a rede pública fazer o ensino médio. Eu soube de toda luta do sindicato quando a companheira Eunice do Monte, que na época era a presidenta, fez uma fala na sala de aula e aquilo me inquietou. Que eu tinha direitos que eu não sabia como tinham sido conquistados e o sacrifício que tinham custado para as demais trabalhadoras que estavam na luta. E então eu perguntei se eu podia me filiar ao sindicato" (PEREIRA, 2018). 
Uma das críticas feitas no meio jurídico ao texto final da Emenda Constitucional $72 / 2013$, as quais eu encampava antes de realizar as entrevistas para esta tese, diz respeito ao "retrocesso" que foi a opção, durante a tramitação do Congresso, por abandonar a ideia de revogar o parágrafo único, migrando para a incorporação de mais incisos do artigo $7^{\circ} \mathrm{a}$ ele, ou seja, para a ampliação do rol de direitos constitucionalmente conferidos às trabalhadoras domésticas. Isso porque a escolha parecia afastar-se da afirmação jurídica da igualdade das trabalhadoras domésticas. No entanto, Benedita da Silva e Tatau Godinho explicaram a linha do raciocínio que levou a essa escolha política.

A deputada, que foi relatora da PEC 478/2010, afirma ter ficado surpresa pelo fato de que encontrar, ao assumir seu mandato na Câmara, "uma [proposta de] emenda constitucional que diz que o direito da empregada doméstica era uma mancha na Constituição, que tinha que tirar aquilo tudo e colocar o que a gente queria lá atrás" (SILVA, B., 2018). A esse respeito, ela julga a proposta de que no texto constitucional conste apenas que as trabalhadoras domésticas têm o mesmo direito dos demais trabalhadores é equivocada:

Mas o tempo nos ensinou. Ao mesmo tempo em que nós achávamos que
era pouco o que estava colocado na Constituição, eu percebi que se nós
[na Assembleia Constituinte] não tivéssemos amarrado ali e colocado o
parágrafo que as trabalhadoras domésticas recebem o mesmo dos
demais trabalhadores, seria letra morta na Constituição. Porque os
argumentos eram voltados ao empregador: 'nós não somos de empresas
e os demais trabalhadores estão nas empresas! Eu fui relatora dessa
PEC e batalhei muito com o proponente, que tinha essa visão de que
tinha que tirar. E eu batalhava dizendo que não tinha que tirar, que o que
nós tínhamos que fazer era regulamentar esse direito. Tirar o FGTS
opcional e colocar o FGTS obrigatório, botar a licença maternidade, ou
seja, aquilo que correspondia a uma CLT. Porque, alternativamente, era
aquilo solto, dos direitos dos demais trabalhadores, mas vinculado a
que? Qual a lei que se iria vincular? Então nós fizemos a Lei do Simples
[Doméstico] e mais parte na CLT. Porque aí a gente tinha respaldo na
Constituição brasileira. Foi uma grande manobra (SILVA, B., 2018).

Assim, a influência de Benedita da Silva foi fundamental, pois embasou essa leitura de que uma equiparação simples de direitos, com a exclusão do parágrafo primeiro, seria letra morta, já que sem adequada regulamentação - que dificilmente viria de um Congresso composto de empregadores domésticos -, os direitos das trabalhadoras domésticas seriam infinitamente questionados e, na prática, não seriam concedidos. Tatau 
explica que essa questão era polêmica entre as trabalhadoras domésticas mobilizadas, mas que ao final prevaleceu a leitura da deputada:

Havia uma proposta de retirar totalmente esse parágrafo e a visão era que automaticamente os direitos seriam equiparados. Já que você está estudando Direito, você sabe que não é assim que funciona no Brasil, não sei se funciona em outros lugares. No Brasil, uma parte muito grande dos direitos que estão previstos na Constituição exige que tenha uma regulamentação, exige que tenha uma lei própria. (...) No momento de maior tensão da negociação, a FENATRAD, outros setores das domésticas e de ONGs do movimento feminista questionavam a estratégia de manter o parágrafo e ampliá-lo. E a Benedita insistiu muito mesmo, e eu lembro demais dessa conversa com ela, que estava com uma insistência brutal para convencer as trabalhadoras de que aquele parágrafo tinha que ser interpretado como um ganho. Que ele foi um ganho em 1988, ninguém teria dúvidas, porque senão não teríamos nada para as domésticas. Ela avaliava, e eu concordo com ela, que continuaria sendo um ganho se ele ampliasse os direitos e dissesse o que era essa ampliação (GODINHO, 2018).

Vale destacar que, tal como na Assembleia Nacional Constituinte, as trabalhadoras domésticas organizadas, em especial a FENATRAD, participaram do projeto durante todo o tempo. Isso foi uma preocupação do governo, que promoveu diversos seminários e apoiou a vinda de representantes das trabalhadoras domésticas para audiências públicas e reuniões, nas quais estavam presentes parlamentares, organizações feministas - como o CFEMEA, Geledés e Themis -, representantes das centrais sindicais, a ONU Mulheres e a OIT (GODINHO, 2018). Segundo Benedita da Silva (2018), as representantes das trabalhadoras domésticas estiveram o tempo todo com ela ao longo da tramitação da PEC 478/2010, concluindo que

para fazer o que fizemos só com o reforço delas. Porque elas - a
FENATRAD, as outras organizações de trabalhadoras domésticas -
também foram falar com os deputados. Não foi a Benedita. Elas que
foram conversar com eles. Eu disse: 'olha, vocês têm que conversar com
a bancada do partido tal, vocês têm que falar com o líder da bancada
tal'. E elas fizeram esse papel.

Tanto as representantes de sindicatos de domésticas entrevistadas, quanto Tatau Godinho e Benedita da Silva concordam que a EC 72/2013 foi aprovada graças ao momento político propício e ao investimento governamental em torno da pauta. A resistência enfrentada, na percepção de Tatau Godinho (2018), "aparecia de forma difusa, em setores da sociedade, no parlamento, muitas vezes numa avaliação econômica em que 
o argumento de proteção das domésticas servia para negar direitos", afirmando-se que aumentar os direitos da categoria significaria o aumento do desemprego. Além disso, ela notou que o drama feito pela mídia argumentando que a aprovação da PEC seria um desastre para as famílias que dependiam de serviços domésticos remunerados logo foi esquecido (GODINHO, 2018).

Também, decorrente da avaliação política de que aquele seria o momento para a aprovação da ampliação constitucional de direitos para as trabalhadoras domésticas, o governo definiu como estratégia deixar temporariamente de lado a ratificação da Convenção 189, sobre trabalho doméstico, da qual o Brasil tinha ativamente participado até então (GODINHO). Essa decisão foi debatida com a FENATRAD, as parlamentares e a OIT, que não se opuseram. Nas palavras de Tatau Godinho, a escolha levou em consideração

(...) a compreensão de que a Convenção 189 é um ganho simbólico importante, tendo um papel político de influência, mas ela tem indiscutivelmente menor eficácia normativa que uma legislação. E a legislação estava na boca do forno, tinha mobilização pra isso. Existe uma coisa que é aproveitar o momento em que pode ter uma vitória. Você imaginaria a vitória de uma legislação como essa, com todas as contradições que ela tem, hoje? Com reforma trabalhista, com todo grau de vulnerabilidade do trabalho, sem nenhuma capacidade de negociação de direitos dos trabalhadores no Congresso?

Toda essa complexa rede de acontecimentos culminou na celebrada aprovação da EC 72, em 2 de abril de 2013, que estendeu às trabalhadoras domésticas 16 novos direitos por meio de inserção de incisos no parágrafo único do artigo $7^{\circ}$ da Constituição de 1988 , alguns com efeito imediato ${ }^{118}$ e outros dependentes de regulamentação legal ${ }^{119}$,

\footnotetext{
${ }^{118}$ São eles: VII - garantia de salário, nunca inferior ao mínimo, para os que percebem remuneração variável; X - proteção do salário na forma da lei, constituindo crime sua retenção dolosa; XIII - duração do trabalho normal não superior a oito horas diárias e quarenta e quatro semanais, facultada a compensação de horários e a redução da jornada, mediante acordo ou convenção coletiva de trabalho; XVI - remuneração do serviço extraordinário superior, no mínimo, em cinqüenta por cento à do normal; XXII - redução dos riscos inerentes ao trabalho, por meio de normas de saúde, higiene e segurança; XXVI - reconhecimento das convenções e acordos coletivos de trabalho; XXX - proibição de diferença de salários, de exercício de funções e de critério de admissão por motivo de sexo, idade, cor ou estado civil; XXXI - proibição de qualquer discriminação no tocante a salário e critérios de admissão do trabalhador portador de deficiência.

${ }^{119}$ São eles, na interpretação de Mauricio Godinho Delgado (2017, p. 423): I - relação de emprego protegida contra despedida arbitrária ou sem justa causa, nos termos de lei complementar, que preverá indenização compensatória, dentre outros direitos; II - seguro-desemprego, em caso de desemprego involuntário; III - fundo de garantia do tempo de serviço; IX - remuneração do trabalho noturno superior à do diurno; XII - salário-família pago em razão do dependente do trabalhador de baixa renda nos termos da lei; XXV - assistência gratuita aos filhos e dependentes desde o nascimento até 5 (cinco) anos de idade em
} 
como o FGTS, a respeito do que tratará o próximo item deste capítulo. Já a Convenção 189 da OIT acabou por ser ratificada apenas recentemente, pelo Decreto Legislativo $172 / 2017$.

De forma geral, a aprovação da EC 72/2013 relevou, para aqueles que se negavam a enxergar que, durante décadas, direitos que são a base da cidadania social no Brasil foram recusados às trabalhadoras domésticas, já que eram tratadas como uma categoria inferior, abaixo dos trabalhadores "padrão", urbanos ou rurais. Na avaliação de Maria Betânia Ávila (2016, p. 139), a regulamentação da jornada de trabalho, por exemplo, constitui "uma nova ruptura com a herança escravista de um tempo de trabalho remunerado sem determinação de horário para começar nem para terminar”.

\subsubsection{A regulamentação pela Lei Complementar 150/2015}

Da necessidade de regulamentação de alguns dos direitos que a EC 72/2013 conferiu às domésticas foi redigido, pela Comissão Mista destinada a tal propósito, o Projeto de Lei do Senado 224/2013, que tramitou na Câmara como Projeto de Lei Complementar 302/2013. Sua aprovação gerou a Lei Complementar 150 , de $1^{\circ}$ de junho de 2015, que regulou amplamente o contrato de trabalho doméstico no Direito Brasileiro (DELGADO, 2017, p. 424), tendo, inclusive, revogado a Lei 5.859/1972.

Dentre os temas mais polêmicos da Lei Complementar, estão: a regulação da inserção obrigatória da empregada doméstica no FGTS, criando depósito especial compensatório dos $40 \%$ rescisórios com o recolhimento de $3,2 \%$ ao mês (artigo 22); a regulação do seguro desemprego com duração e valor específico (artigo 26); a regência normativa da jornada de trabalho, tendo instituído o "banco de horas doméstico" (artigo $2^{\circ}, \S 4^{\circ}$ ) e autorizado o regime 12 por 36 para a categoria (artigo 10); e, finalmente, o reconhecimento do vínculo empregatício apenas para trabalhadoras que prestam serviços “por mais de dois dias por semana" (artigo $1^{\circ}$ ).

A esse respeito, Creuza Oliveira (2016) disse que ela e as demais integrantes da FENATRAD não viam sentido no fato de terem conquistado um direito que, 
posteriormente, precisou passar por uma regulamentação, que acabou por os restringir.

Nas suas palavras:

(...) pegaram uma comissão de regulamentação cheia de macho, não tinha uma mulher, e é uma comissão que não entende, e não quer entender de trabalho doméstico. (...) Essa Lei Complementar 150/2015 tem artigos que são inconstitucionais, como, por exemplo, o banco de horas que só pode acontecer se houver sindicato patronal e sindicato dos trabalhadores para negociar. Então continua o banco de horas para não pagar horas-extras. Tem também a empregada viajante, que a trabalhadora viaja com o patrão e só recebe $20 \%$ a mais do salário, sendo que ela está à disposição e não recebe horas-extras e nem adicional noturno. Tem a trabalhadora diarista, como criaram essa modalidade para poder continuar tendo trabalhadora doméstica em suas casas sem se responsabilizar em assinar a carteira de trabalho. Isso fez com que esse trabalho, que já era precarizado e terceirizado, continuasse dessa forma (OLIVEIRA, 2016).

Sobre a tramitação no Congresso, Tatau Godinho (2018), que acompanhou o tempo todo o processo legislativo, contou a dificuldade de debate com os parlamentares, cujo grande argumento era de que a ampliação de direitos para a categoria tornaria inviável o "controle do custo" do trabalho das domésticas, o que encareceria excessivamente o serviço e deixaria a relação "jurídica demais", de maneira que o empregador individual não teria condições de responder aos novos encargos. Ela continua:

Vou te dar exemplos para você entender. O primeiro é a questão de hora extra: como controlar o tempo e estabelecer um critério de hora extra que não inviabilize economicamente o empregador doméstico? As pessoas não falavam muito sobre a desonestidade, falavam mais sobre o problema da informalidade da relação. 'Porque a doméstica chega, toma o café, e de tarde, quando a criança está na escola, quem sabe ela vê um programa de TV, isso tudo conta como tempo de trabalho?' (...) Diziase: 'como vai medir esse tempo, se você estabelece uma jornada de oito horas e se não dá tempo de cumprir a tarefa do começo do dia e do final do dia?' (...) Outra coisa que me chocou muito era o grau de detalhes que o Congresso se metia. Os senadores discutindo, no caso de viagem com a trabalhadora doméstica, como remunerar a viagem. 'Porque, afinal de contas, ela está viajando!' [diziam alguns]. Mas ela não trabalha $24 \mathrm{~h}$, ela dorme, ela come. Aí a comparação desse tempo com o de um trabalhador tradicional, que viaja, ganha uma diária, e tem jornada de trabalho, mas não está preso ao empregador. 'E como iria fazer com o caseiro do sítio?' Foi nesse nível (GODINHO, 2018).

A respeito da abertura legal para as diaristas, trabalhadoras domésticas nomeadamente autônomas por prestarem seus serviços uma ou duas vezes por semana na 
casa do empregador, Benedita da Silva (2018) afirmou que "não dava pra incluir" no debate, pois significaria levar as negociações parlamentares de volta ao ponto zero, o que “não era justo". Segundo a deputada, "a gente decidiu criar um projeto para a diarista depois, mas naquele momento não dava para caminhar com isso de modo que optou-se por deixar a regulação do trabalho da diarista para um futuro projeto de lei” (SILVA, B., 2018).

Nos debates legislativos em torno do projeto que se tornou a LC 150/2015, verifica-se que a preocupação de grande parte dos congressistas era com os destinatários do cuidado, ou seja, com eles mesmos, mas não com as trabalhadoras. Como bem ponderou Tatau Godinho (2018) na entrevista a mim concedida, se no Brasil contabilizam-se cerca de 6 milhões de trabalhadoras domésticas, existem, por outro lado, 6 milhões de empregadores domésticos, "cada um pensando como isso vai pesar no seu bolso e o quanto isso vai significar de aumento do custo da reprodução cotidiana".

Em termos práticos, vale citar o relato de Eliete Ferreira da Silva (2018), segundo quem "a situação da trabalhadora aqui em Campinas se agravou muito mais, porque os empregadores estão tirando o registro e colocando a mesma trabalhadora para trabalhar duas vezes na semana e dar conta de fazer o mesmo serviço", tendo crescido o número de trabalhadoras que procuram o sindicato por ela presidido com problemas de saúde, não que elas os tenham adquirido a partir de 2015, mas porque o aumento da intensidade do trabalho causou sua manifestação mais rápida.

A análise do processo de afirmação e conquista de direitos para as trabalhadoras domésticas realizada até aqui revela, ainda, resistência, se não mais em admitir que a categoria merece proteção trabalhista ampla, em reconhecer que o trabalho doméstico é trabalho de mesmo valor que os demais. Além disso, revela que o "legislador" não é uma figura abstrata, mas parlamentares com interesses, os quais representam, em sua grande maioria, empregadores domésticos. Sendo assim, se de um lado o estereótipo do “trabalhador" protegido pela legislação trabalhista afeta as domésticas, isso é reforçado pelo padrão de "empregador" usado para justificar o argumento de se tratar de uma relação de trabalho "especial", devendo a lei ser mais complacente com quem, em teoria, não lucra com o trabalho executado.

Isso para mim ficou evidente quando assisti, como parte da pesquisa de campo, a um seminário da Central Única dos Trabalhadores - CUT, em São Paulo, que pretendia 
debater o tema do emprego doméstico. Estavam presentes os mais representativos sindicatos de empregadas domésticas do Estado de São Paulo - Campinas, Franca e São Paulo - bem como a FENATRAD, todos vinculados a esta central sindical e a também presente Confederação Nacional dos Trabalhadores no Comércio e Serviços CONTRACS. ${ }^{120}$

Vale dizer que a CUT tem os debates de gênero e raça como suas bandeiras há bastante tempo, reivindicando para si postura de central sindical verdadeiramente preocupada com as discussões que envolvem emprego doméstico no país. Infelizmente, o que foi visto ao longo do evento foi uma série de contradições entre o discurso e a ação. Primeiro, em termos organizativos: o seminário começou com mais de uma hora de atraso, fazendo com que as mulheres que vieram de Franca e de Campinas perdessem tempo de descanso para estarem na capital; no horário de almoço, a organização do evento avisou em alto e bom som que "as domésticas" iriam para um restaurante e as “demais" (ou seja, as palestrantes, sindicalistas de outras categorias, pesquisadoras etc.) iriam para outro. ${ }^{121}$

A organização das mesas foi uma questão à parte, bem colocada pela Regina Teodoro, ali presente: era absurdo que um evento organizado para discutir emprego doméstico colocasse em primeiro lugar duas mesas com acadêmicas e pessoas ligadas à CUT, deixando para ouvir as trabalhadoras que vieram de longe só para o último momento (às quatro horas da tarde). Irônico, ainda, que aquelas acadêmicas apresentavam resultados de pesquisas feitas junto a essas mesmas mulheres. Em consequência, quando chegou o momento reservado para a fala das trabalhadoras domésticas, os dirigentes se retiraram, alegando outros compromissos.

O questionamento sobre para quem se dirigia aquele seminário ficou no ar ao longo de todo o evento. Para piorar, a secretária nacional de mulher da CUT foi extremamente desrespeitosa com a história de mobilização das trabalhadoras domésticas que ali estavam, dizendo o quanto ela era "boa" com a "sua" empregada por tê-la registrado. Ana Semião (ou Kota), do sindicato de Campinas, mencionou que lutou a vida

\footnotetext{
120 Tratava-se de seminário intitulado "Lutas e Desafios das trabalhadoras Domésticas no Mundo do Trabalho", organizado pelas secretarias da Mulher Trabalhadora e de Combate ao Racismo da CUT Nacional e da CUT-SP, ocorrido no dia 4 de setembro de 2017, no auditório da CUT em São Paulo.

121 Posteriormente, revelaram-me que a separação foi justificada pelo fato de que a CUT pagaria apenas para integrantes dos sindicatos de empregadas domesticas; porém, para quem ouviu de fora a convocação, entendeu como segregação. Foi bastante constrangedor. Optei por seguir o grupo de domesticas, junto com outras colegas pesquisadoras.
} 
inteira para se livrar das amarras patronais para chegar ali e se sentir em um evento patronal, em que a secretária de mulheres fala em "minha doméstica" e acha que pagar 1000 reais para a pessoa que trabalha na casa dela é ser "boa". Que valha de reflexão.

A impressão na saída do seminário era de que aquele espaço tinha sido organizado de forma protocolar, não para de fato ouvir e dar encaminhamento às demandas dos sindicatos ali representados, mas somente para ser usado como demonstração de que o trabalho doméstico está entre as pautas da CUT - o que, inclusive, dá visibilidade internacional à central, já que a OIT tem dado ênfase a essa temática. Sem relevar o papel da CUT e da CONTRACS, que no cotidiano dos sindicatos de domésticas de fato ajudam as diretoras com questões práticas ${ }^{122}$, o seminário evidenciou as contradições dentro das entidades parceiras. Simbolicamente, isso representa que as trabalhadoras domésticas estão por elas mesmas, não podendo contar inteiramente com mais ninguém.

\subsubsection{A organização das trabalhadoras domésticas enquanto categoria}

Historicamente tratadas pelo ordenamento jurídico nacional como uma categoria profissional apartada das demais, conforme visto anteriormente, durante muitos anos a organização sindical das trabalhadoras domésticas não era possível. Não só porque o reconhecimento de direitos para essas trabalhadoras veio apenas com a promulgação da lei 5.859/1972, ainda que de forma precária, mas também devido ao rígido modelo sindical nacional, concentrado na representação do sindicato por categoria (NASCIMENTO, 2009, p. 233).

Assim, a definição de sindicato, no Brasil, envolve a incorporação da noção de categoria, "inerente ao sistema jurídico vigorante no País desde a década de 1930, nesse aspecto, mantido até mesmo pela Constituição de 1988" (DELGADO, 2017b, p. 101). Em suas origens, exigia-se o enquadramento sindical com base no Decreto-lei n. 1.402/1939,

\footnotetext{
${ }^{122}$ Por exemplo, atualmente as diretoras do sindicato de Campinas ajudam o sindicato de Piracicaba a não encerrar suas atividades, tanto por falta de recursos quanto por falta de mulheres dispostas a se engajarem no trabalho da entidade. A CONTRACS nunca negou auxílio durante este processo e, por meio de sua rede de filiados, conseguiu que o sindicato dos bancários da cidade fornecesse, gratuitamente, uma nova sede para as atividades das domésticas em Piracicaba.
} 
somado ao mapa geral das categorias, elaborado pelo Ministério do Trabalho em 1940. Segundo Oliveira Vianna (1943, p. x),

É fácil compreender porque demos preferência - como base inicial da nossa estruturação profissional - ao sindicato por ofício ou categoria e não ao sindicato por indústria (...). O sindicato de ofício ou de categoria é, com efeito, o tipo de sindicato que mais nos convém. É o tipo ideal para a organização profissional de povos como o nosso, sem instituições, nem tradições de solidariedade econômica ou profissional. Pela homogeneidade da sua composição, decorrente da identidade, similitude ou conexidade das profissões ou atividades exercidas pelos seus membros, ele está, aqui (...) em condições de cristalizar mais rapidamente, entre os seus associados, uma forte consciência de unidade e de grupo (...).

Essa lógica foi cristalizada pela CLT (art. 511), atrelando os sindicatos patronais ao conceito de categoria econômica, definida como "a solidariedade de interesses econômicos dos que empreendem atividades idênticas, similares ou conexas, constitui o vínculo social básico que se denomina categoria econômica" $\left(\S 1^{\circ}\right)$, e os sindicatos de empregados ao conceito de categoria profissional, compreendida como "a similitude de condições de vida oriunda da profissão ou trabalho em comum, em situação de emprego na mesma atividade econômica ou em atividades econômicas similares ou conexas $\left(\S 2^{\circ}\right)$.

Logo, o pressuposto é de que a entidade representativa dos interesses dos empregadores envolva alguma forma de atividade econômica, entendida como a produção e circulação de bens ou serviços; isso, por sua vez, determinará a organização da entidade representativa dos trabalhadores, coligados por se acharem inseridos nessa mesma atividade econômica (SILVA, 2012, p. 3-4), com a exceção das categorias profissionais diferenciadas ${ }^{123}$. Por conseguinte, explica Homero Batista Mateus da Silva (2012, p. 4), o sistema brasileiro deixou de fora, a priori, "os empregadores que não exercem atividade econômica, como os membros da administração pública direta e as entidades familiares, que, assim, não podem se associar com prerrogativas sindicais".

Ademais, a CLT referendou, por meio do art. 577, o enquadramento sindical realizado administrativamente pelo Ministério do Trabalho, vinculado ao Quadro de Atividades e Profissões inserido ao final documento consolidado. No referido quadro, correlacionavam-se os grupos de atividade econômica e as categoriais profissionais a eles

\footnotetext{
${ }^{123}$ De acordo com o $\S 3^{\circ}$ do art. 511 da CLT, “categoria profissional diferenciada é a que se forma dos empregados que exerçam profisssões ou funções diferenciadas por força de estatuto profissional especial ou em consequência de condições de vida singulares".
} 
correspondentes, bem como a lista de categorias diferenciadas. Portanto, nosso sistema sindical, como originalmente estruturado, não deixava espaço para o reconhecimento de sindicatos de trabalhadoras domésticas, uma vez que seus empregadores não formam categoria econômica no sentido legal, seus direitos trabalhistas ainda demorariam algumas décadas para serem reconhecidos e elas não constavam no rol do quadro a que se refere o art. 577 da CLT.

A despeito dessa estrutura, a história da organização e luta coletiva das trabalhadoras vem de longa data, tendo como referência a trajetória de Laudelina de Campos Melo, fundadora da Associação de Empregadas Domésticas de Santos, em 1936, primeira do tipo no Brasil e diretamente ligada ao movimento negro de que ela fazia parte (SCHUMAHER; BRAZIL, 2000). Já naquela época, Laudelina fez diversas viagens a fim de articular sua tentativa de reconhecimento das organizações de trabalhadoras domésticas como sindicatos, conforme seu próprio relato em entrevista para Elisabete Aparecida Pinto (1993, p. 342):

O Getúlio já tinha instituído as leis sindicais e ia haver o Primeiro Congresso (de Trabalhadores em 1936)... as empregadas domésticas foram destituídas das leis trabalhistas, nós estávamos criando um movimento para ver se conseguia o registro do Sindicato... eu fiquei no Rio uns três ou quatro dias, no terceiro dia eu consegui com o secretário do ministro. Fui falar com o ministro mas não adiantou nada porque não havia possibilidade de enquadramento da classe das empregadas domésticas. Foram destituídas porque não traziam economia para o país... de repente elas que trazem a economia... nós trazemos economia, elas saem para trabalhar (patroas), principalmente a classe média, eles têm que trabalhar fora, e então passam a escravizar a empregada doméstica.

Anos depois, tendo mudado para o interior paulista, Laudelina foi também a fundadora da associação de trabalhadoras domésticas de Campinas, em 1961, ato que estimulou a fundação de outras organizações com os mesmos objetivos, como a do Rio de Janeiro, em 1962, e a de São Paulo, em 1963 (SCHUMAHER; BRAZIL, 2000). ${ }^{124}$ A pesquisa de Elisabete Aparecida Pinto (1993, p. 374 e anexo III) revela um documento

\footnotetext{
${ }^{124}$ Até hoje o Sindicato de Trabalhadoras Domésticas de Campinas e Região tem sede na casa de Laudelina de Campos Melo, doada por ela para que suas atividades tivessem continuidade. Sua trajetória e luta servem de inspiração para todas as organizações de trabalhadoras domésticas com que tive contato ao longo da pesquisa, sendo o seu rosto que estampa muitos dos cartazes da FENATRAD, por exemplo. Para melhor conhecer a história de Laudelina de Campos Melo, incluindo falas e entrevistas memoráveis dessa heroína nacional, que foi também a primeira a organizar um baile de debutantes para meninas negras, numa época em que a elas era negado participar desse tipo de evento, cf.: PINTO, 1993.
} 
guardado por Laudelina no qual aborda-se a questão da sindicalização das trabalhadoras domésticas, cuja data originalmente atribui-se a 1936, mas que devido ao conteúdo deve ser um pouco mais recente, por mencionar a CLT. Ainda assim, estima-se que seja anterior a 1972, vez que ainda não havia previsão nem mesmo de férias para as trabalhadoras domésticas, além de ter um conteúdo bastante relevante:

\begin{abstract}
Sindicalização dos empregados domésticos
Quando foi promulgada a Lei da Sindicalização no país, sob diversas até certo ponto absurdas alegações, inclusive a de que não produziam para a nação, foram as empregadas domésticas excluídas de qualquer enquadramento sindical, sendo-lhes mesmo proibido de se organizarem em Associações para fins de estudo, defesa, coordenação de seus interesses econômicos e profissionais, conforme estabelece a Consolidação das Leis do Trabalho no Artigo 511 e seus Parágrafos. Muito embora esteja perfeitamente caracterizada a dependência econômica entre empregado e empregadores, no caso domésticos, sua vasta categoria de trabalhadores foi abandonada, posta à margem dos benefícios das leis sociais. Os trabalhadores domésticos: cozinheiras, arrumadeiras, porteiros, pajem, jardineiros, lavadeiras, motoristas particulares (que indevidamente foram afastados dos Sindicatos dos Motoristas) não têm salário mínimo, férias, descanso semanal obrigatório, horário de serviço determinado que possibilite o descanso reparador, aviso prévio, nem mesmo os benefícios assistenciais da Previdência Social, por motivo de não ser permitido a esses trabalhadores se organizarem em entidade de classe oficialmente reconhecida. Constantemente é denunciada a crise de empregos domésticos sendo apontados como causas determinantes outras que não são causas, senão que são efeitos. Um dos motivos da fuga das trabalhadoras domésticas para o ramo de atividades do comércio e da indústria é a falta de garantias, falta de amparo que a sindicalização concede a todo trabalhador (...) (PINTO, 1993, p. 374).
\end{abstract}

A mudança no reconhecimento legal dessas entidades teve como marco a Constituição de 1988, que além de incluir as trabalhadoras domésticas entre os sujeitos do direito do art. $7^{\circ}$, ainda que por meio do Parágrafo único, trouxe no art. $8^{\circ}$ uma série de mudanças no sistema sindical. Nesse sentido, o Quadro de Atividades e Profissões do art. 577 da CLT foi considerado incompatível com a regra constitucional da livre associação profissional sindical (art. $8^{\circ}$, caput) e do simples registro em órgão competente (art. $8^{\circ}$, inciso I). Disso decorre que as categorias profissionais e as categorias diferenciadas arroladas no referido quadro não são uma enumeração exaustiva, só exeplificativa (DELGADO, 2017b, p. 103).

Foi a partir de então que, nas palavras de Homero Batista Mateus da Silva (2009, p. 17), surgem "pequenas brechas na lei brasileira para a constituição de sindicatos de 
trabalhadores livres do conceito de categoria profissional", dentre os quais os sindicatos de empregadas domésticas e de servidores públicos, desafiando a lógica do art. 511, $\S 2^{\circ}$ da CLT, já que lares e prefeituras não exerceriam atividade econômica e não poderiam se associar em sindicatos patronais.

Entretanto, a Constituição de 1988 não estendeu às trabalhadoras domésticas o direito ao reconhecimento das convenções e acordos coletivos de trabalho - o inciso XXVI do art. $7^{\circ}$ não foi incluído no rol do Parágrafo único - e sua não equiparação aos trabalhadores a quem se aplica a CLT impediu que demais previsões, como a obrigatoriedade da contribuição sindical então vigente (art. 578 ss.) ou a estabilidade de dirigente sindical (art. 453, $\S 3^{\circ}$ ), fossem a elas aplicadas. Creuza Oliveira (2016) explica a situação da seguinte maneira:

Em 1988, com o advento da Constituição, houve a importância da questão do direito, mas também da transformação de associação em sindicato. A maioria das associações foi transformada em sindicatos e nós chegamos a ter mais de trinta sindicatos, que eram grupos e associações que foram transformados. Mas a gente conquistou o direito de se organizar em sindicato sem os mesmos direitos da organização sindical, como por exemplo, o direito à estabilidade sindical e a contribuição sindical, que a gente não tinha e continuamos a não tendo.

O cenário mudou com a Emenda Constitucional 72/2013, uma vez que o reconhecimento das convenções e acordos coletivos de trabalho passou a ser direito das trabalhadoras domésticas (art. $7^{\circ}$, Parágrafo único da Constituição). Em decorrência da nova previsão, sindicatos patronais de empregadores domésticos também foram permitidos, uma vez que a convenção coletiva exige negociação entre duas entidades sindicais, uma patronal outra profisssional. A mudança, todavia, parou por aí, não tendo havido regulamentação, por exemplo, dos meios de garantia de arrecadação para esses sindicatos, o que manteve barreiras para a categoria, conforme relata Creuza Oliveira (2016): "tudo que os outros trabalhadores organizados têm, nós não tínhamos e continuamos não tendo, porque a Lei 150/2015 avançou um pouco na organização trabalhista, mas não avançou na organização sindical”.

Sem entrar no mérito dos inúmeros problemas do sistema sindical brasileiro ${ }^{125}$, vale dizer que a reforma trabalhista, trazida pela Lei 13.467/2017, extinguiu a obrigatoriedade da contribuição sindical (nova redação dos art. 545, art. 578 e ss. CLT), o

\footnotetext{
${ }^{125}$ Muitas obras fazem a crítica aos resquícios corporativistas do sindicalismo brasileiro, em especial a unicidade e a contribuição compulsória. Cf.: SILVA, 2001; SILVA, 2012.
} 
que equiparou, sob o ponto de vista das trabalhadoras domésticas, os demais sindicatos profissionais aos sindicatos de sua categoria, que historicamente dependem de contribuições associativas e financiamento externo para a manutenção de suas atividades. A dificuldade de sua organização, porém, deve-se a um quadro muito mais amplo, descrito por Creuza Oliveira (2017):

A organização das domésticas é muito difícil por sermos majoritariamente mulheres negras com baixa escolaridade. Antigamente era ainda pior, porque as trabalhadoras domésticas moravam na casa dos patrões (...). A categoria está dispersa. Cada uma trabalha em uma residência e é difícil para nós sindicalistas, termos acesso ao local de trabalho para distribuir os informativos. As outras categorias de trabalhadoras e trabalhadores encontramos nas empresas, nos refeitórios, as pessoas trabalham juntas, etc. A trabalhadora doméstica está dentro da casa isolada e é difícil acessá-la. Temos feito malabarismo para conseguir chegar perto dessas trabalhadoras, que foram ensinadas que a mulher não faz política, que sindicalismo é coisa de homem, não de mulher. Tentamos chegar por meio das escolas públicas noturnas, onde estão as trabalhadoras domésticas que estudam à noite. Outro espaço são os pontos de ônibus pela manhã logo cedo, quando estão indo para o trabalho, nos bairros de classe média, condomínios de luxo, etc, ou final da tarde, quando estão retornando para casa.

Ainda com toda essa dificuldade, para as líderes de associações e sindicatos de trabalhadoras domésticas com quem convivi, a organização sindical é crucial, tendo sido inclusive por meio das quais elas recebem formação política, aprendem seus direitos e transmitem seus conhecimentos para outras companheiras. Por esse motivo, grandes esforços foram feitos ao longo de 2017 para que a Federação Nacional de Trabalhadoras Domésticas, que existe desde 1997, fosse oficializada enquanto entidade sindical de segundo grau; conseguir reunir cinco sindicatos regularmente inscritos no Ministério do Trabalho e toda a documentação para dar entrada no registro da federação foi uma tarefa quase hercúlea, mas que elas julgam representativa da força de sua luta por direitos (FENATRAD, 2017).

\subsection{REGULAMENTAÇÃO DA PROFISSÃO DE CUIDADORA}

O trabalho de cuidado remunerado no Brasil é exercido, predominantemente, por trabalhadoras domésticas, das quais são demandadas tarefas que mesclam a atenção e 
cuidado de crianças e idosos com a limpeza da casa ou a preparação de refeições. Além de a família ser o centro preferencial do cuidado no país (GRATAO, 2012), normalmente a responsabilidade pelo cuidado de crianças ou idosos dependentes é de um de seus membros, $60 \%$ dos quais dividem essas tarefas com trabalhadoras domésticas (SANTOS; RIFIOTIS, 2006, p. 6).

Assim, o papel de cuidadora ou babá muitas vezes é atribuído às trabalhadoras domésticas, que acabam por exercer diversas atividades, desde trabalhos pesados de limpeza, até o trabalho emocional de cuidado. Nadya Araújo Guimarães, Helena Hirata e Kurumi Sugita (2012, p. 86-87) apontam como indicador expressivo do quanto essas profissões se confundem os dados provenientes da Pesquisa Emprego e Desemprego (PED) de 2008 para a região metropolitana de São Paulo, que revelam que a grande maioria das trabalhadoras entrevistadas, apesar de desempenharem tarefas de cuidado, autoidentificavam-se como empregadas domésticas, não como cuidadoras, percepção que "reflete o escasso reconhecimento institucional de que gozam essas profissionais".

Em termos jurídicos, isso significa que as normas de Direito do Trabalho que regem as mais diversas atividades de cuidado no Brasil são as normas voltadas ao emprego doméstico, vistas no item anterior, perpetuando uma percepção sexista e economicista de que se tratariam de atividades que não demandam habilidades ou especialização, logo, desvalorizadas e rotuladas como secundárias. Por esse motivo, tem crescido movimentos para que a lei brasileira incorpore formas de regular profissões relacionadas ao cuidado de forma específica, descrevendo as atividades que cada profissional pode exercer e delimitando suas responsabilidades. Assim, por exemplo, as atividades de uma cuidadora de idosos serão voltadas ao bem-estar da pessoa cuidada, não abordando o cuidado com a família ou a limpeza da casa; do mesmo modo, o trabalho da babá se limita às atividades que dizem respeito ao cuidado da criança, como o dever de alimentá-la, mas não de cozinhar para todas as pessoas da casa.

Regular o trabalho das cuidadoras e outras trabalhadoras do cuidado como profissões específicas torna-se, então, um meio de promover o "reconhecimento e a valorização do trabalho doméstico e do trabalho familiar como "trabalho", fazendo com que a associação do trabalho de cuidado a um papel feminino deixe de ser natural, o que possibilita sua visibilidade, profissionalização e uma maior igualdade de gênero no trabalho (GUIMARÃES; HIRATA; SUGITA, 2012, p. 84). Não significa dizer que seja a 
solução para os problemas até agora descritos, mas sim uma via para se estabelecerem condições de trabalho decente a estas profissionais.

Nesse sentido, os primeiros debates sobre a profissão em termos institucionais decorreram de demandas sociais pautadas na Política Nacional do Idoso, de 1994 (BATISTA; ALMEIDA; LANCMAN, 2014, p. 880); mas foi em 1999, com a Política Nacional da Saúde do Idoso, que o Governo Federal, por meio da Portaria 1395/1999 do Ministério da Saúde, estabeleceu a seguinte definição de "cuidador":

(...) pessoa, membro ou não da família, que, com ou sem remuneração, cuida do idoso doente ou dependente no exercício das suas atividades diárias, tais como alimentação, higiene pessoal, medicação de rotina, acompanhamento aos serviços de saúde ou outros serviços requeridos no cotidiano - por exemplo, ida a bancos ou farmácias -, excluídas as técnicas ou procedimentos identificados com profissões legalmente estabelecidas, particularmente na área da enfermagem.

Posteriormente, houve a institucionalização do termo "cuidador", na Classificação Brasileira de Ocupações (CBO) do Ministério do Trabalho e Emprego, pela Portaria Ministerial n. 397/2002, em que se caracterizou o cuidado "de crianças, jovens, adultos e idosos" como ocupação integrante da família do "prestador de serviço", catalogada pelo código n. 5162. Transcrevo abaixo a descrição da CBO:

\begin{abstract}
TÍTULO:
5162-05 Babá - Baby-sitter; Pajem (baby-sitter em início de carreira). 5162-10 Cuidador de idosos - Acompanhante de idosos; Cuidador de pessoas idosas e dependentes; Cuidador de idosos domiciliar; Cuidador de idosos institucional; Gero-sitter.

5162-15 Mãe social - Mãe crecheira; Mãe substituta.

DESCRIÇÃO SUMÁRIA: Cuidam de bebês, crianças, jovens, adultos e idosos, a partir de objetivos estabelecidos por instituições especializadas ou responsáveis diretos, zelando pelo bem-estar, saúde, alimentação, higiene pessoal, educação, cultura, recreação e lazer da pessoa assistida (...). CONDIÇÕES GERAIS DE EXERCÍCIO: O trabalho é exercido em domicílios ou instituições cuidadoras de crianças, jovens, adultos e idosos. As atividades são exercidas com alguma forma de supervisão, na condição de trabalho autônomo ou assalariado. Os horários de trabalho são variados: tempo integral, revezamento de turno ou períodos determinados. No caso de cuidadores de indivíduos com alteração de comportamento, estão sujeitos a lidar com situações de agressividade. (...) ESTA FAMÍLIA NÃO COMPREENDE: 3222 - Técnicos e auxiliares de enfermagem (MTE, 2010).
\end{abstract}

A inclusão na CBO fez com que a atividade passasse a ser considerada nas estatísticas da Relação Brasileira de Informações Sociais (Rais), mas seus efeitos são 
apenas de ordem administrativa, não equivalendo à regulamentação da profissão feita por via legislativa. Essa lacuna no ordenamento jurídico nacional fere outras normas, como o Estatuto do Idoso (Lei 10.741/ 2003), cujo art. 18 prevê o treinamento e a capacitação dos profissionais e orientação das cuidadoras familiares para o cuidado do idosos, bem como a ausência de uma definição para a profissão torna precária a elaboração de currículos para cursos de formação dessas profissionais, mantendo o estereótipo de se tratar de atividade de baixa qualificação e baixo valor.

Por conta desse panorama, a pauta pela regulação da profissão de cuidadora é frequentemente colocada em debate no Legislativo, atrelada à justificativa de que a mudança jurídica seria o passo para a valorização, qualificação e institucionalização da atividade (cf. PL 2880/2008, da Câmara dos Deputados). Esse é o discurso de Lidia Nadir Giorge (2017), presidenta da Associação de Cuidadores de Idosos da Região Metropolitana de São Paulo - ACIRMESP, que afirma estar "há quatro anos [desde que entrou na associação] batalhando para que o envelhecimento seja mais viável para todos", o que ela faz por meio de articulação com deputados e senadores envolvidos com projetos de lei relativos à temática. Sob sua perspectiva, a regulação seria um meio de garantir a formação dessas profissionais (GIORGE, 2017).

No Congresso Nacional há um número considerável de projetos de lei a esse respeito - como o Projeto de Lei 2.880/2008, da Câmara, em fase recursal que tenta impedir seu arquivamento -, merecendo destaque: o Projeto de Lei da Câmara 11/2016, que originalmente versava sobre babás, mas cuja ementa em debate no Senado fala na criação e regulamentação das "profissões de cuidador de pessoa idosa, cuidador infantil, cuidador de pessoa com deficiência e cuidador de pessoa com doença rara"; e o Projeto de Lei do Senado 284/2011, já aprovado na casa e remetido à Câmara como PL 4702/2012, que "dispõe sobre o exercício da profissão de cuidador de pessoa idosa", ao qual foram apensados os projetos de lei 2178/2011, 4114/2015 e 7216/2017.

Com andamento mais avançado, aguardando votação em plenário desde julho de $2016^{126}$, o PL 4702/2012 tem como pontos de destaque a delimitação do exercício da profissão para maiores de 18 anos, com ensino fundamental completo e curso de formação de cuidador de pessoa (art. $3^{\circ}$ ), o que demandará do Governo a definição

\footnotetext{
126 Cf. informação da Câmara dos Deputados. Disponível em: $<$ http://www.camara.gov.br/proposicoesWeb/fichadetramitacao?idProposicao=559429>. Acesso em: 24 jul. 2018.
} 
curricular e o fomento de cursos profissionalizantes voltados à área. No projeto consta também a vedação de que o empregador exija da cuidadora "a realização de outros serviços além daqueles voltados aos idosos, em especial serviços domésticos de natureza geral” (art. $4^{\mathrm{o}}, \S 2$ ), uma opção legislativa delicada, pois exigirá que seja formulada a maneira de separar o cuidado da pessoa de demais tarefas domésticas, o que não é simples já que, muitas vezes, o local de prestação do serviço e as atividades se confundem, como é o caso da preparação da comida ou higienização de determinados espaços da casa.

Nesse sentido, Guimarães, Hirata e Sugita (2011) falam da continuidade dos diversos cuidados, no sentido de que muitos atos de cuidado estão envolvidos dentro de um mesmo campo, mas que essa continuidade não se revela entre diferentes campos do cuidado (trabalho doméstico, cuidado de idosos, cuidado de crianças etc.). Assim, por mais que no Brasil possa parecer praticamente impossível separar as tarefas do trabalho doméstico e do cuidado de um idoso, por exemplo, por ser comum que as trabalhadoras domésticas exerçam diversas funções do cuidado, a tentativa de definir as tarefas que cabem a cada um pode ser um passo para melhorar a prestação dos serviços para quem os recebe e para quem os exerce. A exemplo do Japão, onde quase não existem empregadas domésticas, "a continuidade dos cuidados é dificilmente concebível, requerendo, por isso mesmo, uma combinação entre diferentes agentes prestadores de cuidados", no que se incluem familiares, ajudantes com contrato privado, homehelpers e/ou instituições de cuidados (GUIMARÃES; HIRATA; SUGITA, 2011, p. 160).

Um ponto a ser revisto do referido projeto é que seu art. $4^{\circ}$ prevê que cuidadoras contratadas por pessoa física para cuidado próprio ou de familiar terão a relação regida pela revogada Lei 5859/1972, prevendo também a possibilidade de contratação da profissional como celetista, em caso de empregador pessoa jurídica, e também como Microempreendedora Individual. Além de ser bastante questionável a tentativa de permitir a contratação de cuidadora como MEI, devido à abertura para fraudes trabalhistas, o projeto de lei precisa ser atualizado para fazer menção à aplicação da Lei Complementar 150/2015, porque é ela que atualmente rege a relação de emprego doméstico - o que no caso do PLC 11/2016 já está devidamente atualizado (art. $4^{\circ}$ ).

Ao observar a tramitação dos referidos projetos, ficam evidentes as dificuldades e barreiras para avanço e aprovação da regulação da profissão. Lidia Nadir Giorge (2017) relata que o PLC 11/2016 tinha pareceres favoráveis no Senado, mas que no fim de 2016 sua votação foi tirada de pauta por pressão dos sindicatos e da Federação Nacional de 
Enfermeiros. Segundo ela, essa interferência não faria sentido, pois "os enfermeiros e afins cuidam da saúde do paciente e os cuidadores cuidam da vida diária do paciente”, ou seja, não haveria sobreposição de funções, pois “o cuidado do enfermeiro é pontual e o do cuidador é diário" (GIORGE, 2017).

Raquel Noel Ribeiro (2015, p. 66) descreve a resistência das associações relacionadas à enfermagem como uma disputa de monopólio de mercado, mencionando nota do Conselho Federal de Enfermagem, de 2012, na qual o órgão expressa sua preocupação com a criação da profissão de cuidador de idosos, afirmando que não permitirá que suas atribuições conflitem com o exercício profissional da enfermagem. Benedita da Silva (2018), relatora do projeto de lei 4702/2012, também destacou a dificuldade de diálogo com o referido setor, colocando a questão nos seguintes termos:

Elas [representantes de profissionais da enfermagem] acham que [a profissão de cuidadora] entra na competência delas, mas não entra. Porque enfermeira não é para ficar limpando bunda, honestamente falando. As enfermeiras são a complementação do trabalho do médico. $\mathrm{E}$ as cuidadoras são cuidadoras em todos os momentos da vida da pessoa. Eu posso ser uma deficiente física e ter uma cuidadora. Enquanto que a enfermeira não vai querer fazer esse trabalho. Uma pessoa que está obesa, uma enfermeira vai ficar cuidando? Não vai. Mas não é só isso. Tem os médicos também. Porque, com a presença das cuidadoras, você populariza o atendimento (SILVA, B., 2018).

Independente da via, a regulação da profissão de cuidadora mostra-se como um fator em potencial que pode contribuir para que as trabalhadoras do ramo tenham reconhecimento jurídico e amparo legal quanto a seus direitos e deveres no exercício profissional, evitando abusos dos empregadores, além de conferir à pessoa beneficiária do cuidado a segurança de uma boa prestação do serviço e de ampliar a demanda por iniciativas do governo para promoção e investimento em cursos voltados à área (VIEIRA, 2013). Verifica-se, portanto, usando as palavras de Thierry Ribault (2012, p. 129), que o "bem-estar da pessoa beneficiária do serviço e a garantia de condições de trabalho e de emprego sustentáveis para quem realiza este serviço não podem ser concebidos separadamente". 


\subsection{MERCANTILIZAÇÃO DO CUIDADO, FINANCEIRIZAÇÃO E REFORMA TRABALHISTA}

A reflexão sobre a desvalorização do trabalho doméstico remunerado e não remunerado no Brasil na atualidade deve considerar o cenário de intensas mudanças das duas primeiras décadas do século XXI, processo que levou ao distanciamento cada vez maior do horizonte de direitos sociais corporificado na Constituição de 1988. A fim de inserir neste capítulo problemáticas contemporâneas que convergem com os debates sobre provisão do cuidado em âmbito nacional, buscarei enfrentar alguns pontos dessa conjuntura, observando na opção feita no início dos anos 2000 da inclusão pelo consumo e desinstitucionalização do sistema de proteção social, a fim de chegar à crítica da mercantilização dos serviços públicos que se delineia no Brasil, em específico daqueles ligados ao cuidado, que se soma à ofensiva aos direitos sociais, em iniciativas como a reforma trabalhista aportada pela Lei 13.467/2017.

Em termos de política social, a escolha política da inclusão pelo consumo, com transferência monetária direta via programas assistenciais e prestações previdenciárias, ao longo da década de 2000, permitiu a milhões de brasileiras e brasileiros o acesso a bens de consumo e fomentou o crescimento econômico. Numericamente, benefícios previdenciários retiraram 21 milhões de pessoas da pobreza e 19 milhões da miséria, merecendo destaque a universalização do sistema de aposentadoria rural, pactuado na Constituição de 1988, e benefícios assistenciais, como o Programa Bolsa Família e o Benefício de Prestação Continuada, reduziram o número de pobres em 7 milhões e o de indigentes em 4 milhões (LAVINAS, 2015, p. 4). ${ }^{127}$

Como decorrência, porém, houve um processo de endividamento e maior vulnerabilização das classes populares, gerado pelo amplo acesso ao mercado de crédito, somado à precarização e desinstitucionalização do sistema de proteção social ainda nos governos Lula e Dilma (LAVINAS, 2015, p. 3). Durante esses governos, o gasto social no Brasil ocorreu da seguinte maneira: "60\% tomam a forma de transferências monetárias, ao passo que a provisão de serviços desmercantilizados segue minoritária e aquém do estabelecido em lei" (LAVINAS, 2015, p. 3-4).

\footnotetext{
${ }^{127}$ Sobre aposentadoria rurual, ver: OIT. As boas práticas brasileiras e seguridade social. v.1. Brasília: OIT, 2012. p. 67-79
} 
Uma das frentes da derrocada do sistema de proteção social foi a crescente financeirização da política social (LAVINAS, 2015) e desinvestimento na provisão e infraestrutura de serviços públicos, como creches, escolas, restaurantes populares e instituições de cuidados de idosos. Passada mais de uma década de esforços dos governos do Partido dos Trabalhadores em consolidar um modelo social-desenvolvimentista baseado no consumo em massa (LAVINAS, 2015), o ataque desavergonhado à estrutura de proteção social foi posto em prática pelo governo Temer, com a reforma trabalhista trazida pela Lei $13.467 / 2017$ e as tentativas e projetos de reforma previdenciária que tramitam desde 2017, convergindo com outras iniciativas já vigentes, como a EC 95/2016, que congelou os gastos públicos pelos próximos 20 anos.

Temos assim, a pressão do capital pela financeirização dos direitos sociais, apontada por economistas desde o começo dos anos 2000 (LAVINAS, 2015), somada a um mais recente processo de desmonte desfreado dos direitos sociais pela via jurídica, empreitado via reformas legislativas, decretos e até por decisões do STF $^{128}$. Tal configuração torna mais complexo o debate sobre a provisão do cuidado e mais longínquas as saídas para uma maior igualdade entre homens e mulheres e para a responsabilização do Estado em fornecer serviços em quantidade e de qualidade.

Com relação à perspectiva macroeconômica, Lena Lavinas (2016, p. 624) faz alusão ao relatório da ONU Mulheres (2015) sobre o fato de a igualdade de gênero formal não ter sido acompanhada de uma igualdade de real, constatando a "centralidade do investimento em serviços sociais e na garantia de uma provisão pública na quantidade e na qualidade esperadas para reverter níveis agudos de desigualdade e de destituição". A autora enfatiza a necessidade de ser priorizado o gasto "in kind", com a provisão desmercantilizada de serviços públicos - investimento em saúde, educação, creches, infraestrutura urbana, no lugar do subsídio ao consumo -, porque:

(...) os homens dependem das mulheres para dispor de bem-estar e qualidade de vida, enquanto as mulheres precisam de serviços públicos acessíveis e a custos razoáveis para não serem as únicas provedoras responsáveis por assegurar, para além de suas capacidades, recursos e vontade, condições satisfatórias de reprodução da vida. Na ausência da

\footnotetext{
${ }^{128}$ Refiro-me, em especial, ao julgamento da ADPF 324, publicada dia 31 de agosto de 2018, em que o STF decidiu ser lícita a terceirização em todas as etapas do processo produtivo, em confronto com a jurisprudência construída pela Justiça do Trabalho de que apenas seria possível terceirização em atividades meio (Súmula 331 do TST). Com essa decisão, a Corte dá aval a uma maior precarização das relações de trabalho, uma vez que a terceirização no Brasil é utilizada na grande maioria das vezes para pagar menores salários, reduzir encargos trabalhistas e para ocultar fraudes. Cf. SILVA, 2018
} 
provisão pública adequada, a carga repousa quase que exclusivamente sobre as mulheres, sobre o trabalho não remunerado e invisibilizado das mulheres (LAVINAS, 2016, p. 624).

A fim de melhor compreender este quadro de ausência de investimento público tão danoso às mulheres, cabe primeiro delinear o processo de financeirização da economia brasileira, que Lena Lavinas e Denise Gentil (2018, p. 195) explicam partindo da percepção de que o "setor financeiro tem buscado sistematicamente conquistar novos espaços de revalorização e encontrou nos serviços tradicionalmente providos pelo Estado, como saúde, educação e previdência social, um nicho para se expandir", o que é feito com colaboração do Estado a partir do momento em que "reduz ou deteriora sua oferta pública de forma que desestimula a demanda da sociedade e a induz a buscar no mercado aquilo que deveria ser direito". Foi o que ocorreu no período de 2003 a 2016 no país, em que ocorreu grande processo de delegação ao setor financeiro de serviços prestados pelo Estado no campo da proteção social, alcançando inclusive a esfera da reprodução social (LAVINAS; GENTIL, 2018, p. 195).

Nesse contexto, as autoras apontam como o eixo principal da acumulação rentista o modelo de gestão da dívida pública interna, "acoplada a uma política monetária conservadora", concentrando a riqueza predominantemente nas mãos dos bancos, fundos de investimento e pensão, seguradoras e grandes empresas globais. Elas apontam que a característica fundamental dos anos 2000 foi uma "financeirização em massa", na qual substituíram-se os ganhos inflacionários pela "elevada renda de juros e demais modalidades de ganhos financeiros", seja derivados do endividamento público interno ou do crescente endividamento das famílias e empresas não financeiras (LAVINAS; GENTIL, 2018, p. 198).

É possível elencar alguns exemplos que permitem enxergar tal quadro, como a reforma do Regime Próprio da Previdência Social dos servidores públicos com a EC 41/2003, a criação de programas de transferência de renda em larga escala e de baixo custo e a reformatação do Fundo de Financiamento Estudantil que é um dos fatores para uma profunda mudança de perfil das universidades, que passam a ser grandes grupos do com capital aberto, dinâmica similar à que ocorreu no setor de saúde suplementar (LAVINAS; GENTIL, 2018). Nos últimos dois casos, a "compra de empresas dos setores de saúde e educação por fundos de investimentos e por investidores estrangeiros que 
atuam no mercado de capitais" é preocupante porque permite que as ações desses hospitais, planos de saúde, laboratórios, faculdades privadas sejam compradas por instituições que não estão "implicadas com a qualidade da provisão desses serviços" (LAVINAS; GENTIL, 2018, p. 202).

O gradual abandono dos investimentos sociais nas últimas décadas no país é observado não apenas nas ações governamentais, mas na sociedade civil, valendo mencionar a inserção de planos de saúde privados nas negociações coletivas, o que indiretamente demonstra que os sindicatos nacionais desistiram da luta pela universalização do direito à saúde, necessário para a manutenção da vida de trabalhadoras e trabalhadores. Assiste-se, assim, a um sucateamento dos serviços públicos que no Pacto de 1988 deveriam ser eixo da construção de uma estrutura brasileira de bem-estar social, sem que haja resistência social relevante.

Conforme pesquisa do DIEESE (2015, p. 50), as cláusulas sobre assistência médica nos acordos e convenções coletivas costumam, em sua maioria, "tratar das regras dos planos de saúde contratados pelas empresas e o desconto pago pelo trabalhador pela utilização dos serviços". Uma das convenções coletivas de trabalho consideradas mais avançadas é a dos bancários da Caixa Econômica Federal, que prevê cobertura do plano de saúde que cubra inclusive para assistência psicológica e de medicina alternativa, além do direito à manutenção do plano na aposentadoria (DIEESE, 2015, p. 51). A crítica a esta opção de assistência médica privada vem do próprio departamento responsável pela pesquisa:

\footnotetext{
Cláusulas referentes à assistência médica geralmente orientam o acesso dos trabalhadores aos serviços e condições determinadas pelos planos de saúde que as empresas contratam, desconsiderando importantes ações previstas pelo Estado, intermediadas pelo Sistema Único de Saúde SUS. (...) Nenhuma das cláusulas presentes no SACC-DIEESE no período 2011-2012 faz referência a Programas e/ou Centros de Referência de Saúde do Trabalhador, aliados importantes no desenvolvimento e implantação de políticas públicas em saúde do trabalhador (DIEESE, 2015, p. 51)
}

As demandas sindicais pela contratação de planos de saúde estão presentes não apenas nas cláusulas coletivas referentes a doenças não profissionais, mas integram também as principais reivindicações das greves classificadas no tema saúde do trabalhador: entre 2010 e 2012 foram 204 greves com essa reivindicação mapeadas pelo 
DIEESE (2015, p. 72-73). Friso que a escolha política sindical foi de pressionar os empregadores no fornecimento de planos de saúde, deixando de lado as reivindicações voltadas ao Estado para investimentos e garantia de um sistema público de saúde de qualidade. Isso significa optar por um sistema de inclusão social do cidadão empregado, que de certa maneira ignora a realidade dos desempregados e, ainda mais, do expressivo volume de trabalhadoras e trabalhadores precários - incluindo terceirizados, informais, por conta própria - que dependem do amparo do SUS.

O panorama, portanto, demonstra o afastamento gradual das demandas por cuidado do eixo da socialização e responsabilização do Estado e sua aproximação a um debate individualizado e privatista, que não deixa saída para as famílias que não buscar arranjos domésticos, não remunerados, que penalizam as mulheres sobre as quais recaem tais encargos, ou mercantilizar de modo desregulado as prestações de cuidado, o que envolve a exploração de outras mulheres.

Alerto que a crítica aqui não diz respeito ao processo que tornou mercantil uma atividade que antes era feita no interior das famílias, cuja execução cabia às mulheres por obrigação ou "amor", sem remuneração. Numa sociedade com expressivos contingentes de mulheres na força de trabalho, elevado número de crianças e crescente número de idosos não é possível recusar que parte do cuidado seja mercantilizada (Cf.: GUIMARÃES; BRITO, 2016). Entretanto, é preciso atentar para duas coisas: que essa mercantilização é efetiva para uma parcela pequena e privilegiada da população, enquanto nas classes baixas o cuidado acontece ancorada em redes de solidariedade; e que a mercantilização isolada e encarada como saída única para o cuidado é danosa justamente para essa parcela das mulheres, mais pobres, que não tem condição de pagar por esses serviços, motivo pelo qual é preciso debater provisão pública desses serviços.

Não bastando esse processo de desgaste das estruturas sociais, com o golpe de Estado de 2016, que permitiu que Michel Temer assumisse a presidência da República, passou a ocorrer uma ofensiva direta e acelerada aos direitos sociais, começando pelo congelamento de gastos públicos por 20 anos - EC 95/2016 -, passando pelas tentativas de reforma da Previdência Social, e chegando à reforma trabalhista, promulgada pela Lei $13.467 / 2017$.

A entrada em vigor desta última lei alterou, em profundidade, o modo como o Brasil trata os direitos trabalhistas e expõe uma postura que coloca as mulheres em lugar 
secundário no mercado, como força de trabalho de menor valor. Isso se vê, conforme descrição de Patricia Maeda (2018), em pontos como: (i) expansão das formas de contratação autônoma e de precarização do vínculo contratual, o que atinge em especial as mulheres que estão na informalidade e em outras atividades consideradas atípicas ${ }^{129}$; (ii) criação de serviços com tempo de trabalho não tradicional, como o contrato intermitente, ou o trabalho em tempo parcial ou o regime $12 \times 36$, que supostamente se enquadrariam melhor às responsabilidades familiares porque acabam como única alternativa das mulheres ${ }^{130}$; (iii) manutenção da igualdade salarial formal, que não se reflete em igualdade material; (iv) relativização da proteção à maternidade com a retirada da previsão de não trabalho da gestante e lactante em serviços insalubres e previsão expressão de que o descanso especial para amamentação pode ser definido por acordo individual; e (v) a abertura de possibilidade de que a convenção coletiva de trabalho tenha prevalência sobre a lei, podendo inclusive reduzir direitos em um contexto em que as mulheres são sub-representadas nos sindicatos.

Ainda que a reforma trabalhista seja voltada para a CLT, ela não apenas gerou alerta entre as trabalhadoras domésticas, por representar uma potencial redução de direitos para a categoria, como alguns dos dispositivos da CLT reformados podem ser aplicados a elas, como é o caso das novas regras referentes ao processo do trabalho ou de normas que podem ser aplicadas subsidiariamente às relações de emprego doméstico, dentre as quais figura o aval do negociado sobre o legislado. Nesse sentido, elucida as atuais preocupações da FENATRAD a sua presidenta, Luiza Pereira:

\footnotetext{
${ }^{129}$ Experiências profissionais que são realidade para a maioria das mulheres: "o total de ocupadas com 15 anos ou mais, 40\% estavam em atividades consideradas atípicas, como o trabalho doméstico, trabalhando por conta própria, em atividades não remuneradas ou trabalhando na produção para o próprio uso ou consumo; entre os homens, o percentual para o mesmo período era de $32 \%$, conforme dados da PNAD de 2015” (TEIXEIRA, 2017, p. 17).

${ }^{130}$ Nas palavras da autora: "Como podemos pensar a garantia da proteção à maternidade num contrato de trabalho intermitente (ou temporário ou terceirizado)? A ausência de chamamento para o trabalho não rompe o contrato, mas também não provê salário nem média salarial para a licença-maternidade. Além disso, a ausência de chamamento pode também esconder uma forma de discriminação, perseguição e até mesmo assédio, situações em que o trabalho precário vulnerabiliza ainda mais a condição da trabalhadora (e também do trabalhador). (...) O elastecimento da jornada fica naturalizado com a previsão do sistema 12X36 instituído por acordo individual escrito, sem ao menos resguardar o direito ao intervalo para repouso e alimentação, que pode ser indenizado, nem ao descanso semanal remunerado ou feriados, que são considerados já compensados (!). Com este vale-tudo em termos de horário de trabalho, certamente ninguém pensou no déficit de creches públicas, cujos horários são rigorosos e que não contam com sistema de banco de horas nem 12X36. O vale-tudo inviabiliza não só o convívio familiar, mas também o cuidado de crianças e idosos, , ainda imputado à mulher em nossa sociedade, sem contar a sobrecarga resultante de sua confluência com a dupla jornada das tarefas domésticas” (MAEDA, 2018).
} 
A mudança na lei afetou toda a classe trabalhadora. A gente tem uma preocupação maior especialmente em dois pontos, a jornada intermitente e o negociado sobre o legislado (...). Porque a jornada intermitente, mesmo com a carteira assinada, possibilita o empregador pagar só pelas horas trabalhadas e nós, trabalhadoras domésticas, que sempre fomos historicamente exploradas nessa questão da jornada de trabalho, sabemos que tem muito empregador que chama para trabalhar doze horas o dia. E digamos que no outro dia precisa trabalhar só três horas. E aí não fecha nem dois dias de trabalho somando as horas dos dois dias. No final do mês, o empregador só vai pagar aquele valorzinho das horas trabalhadas. (...) Então a gente discute muito isso, que foi muito prejudicial para as empregadas domésticas, principalmente porque existe uma correlação de forças em que a trabalhadora doméstica está mais desprotegida do que outras categorias (PEREIRA, 2018).

Regina Teodoro (2018) resume a apreensão das trabalhadoras domésticas organizadas no seguinte sentido: "a gente apoiava aquilo de 2013 e não o que virou a Lei Complementar 150/2015, que acabou com tudo; e agora vem o governo e acaba um pouco mais". A sensação diante dessa conjuntura é explicada por Benedita da Silva (2018):

Desde a Constituinte que as trabalhadoras foram crescendo nas suas organizações, tanto assim que elas têm os sindicatos delas etc. E tem até os das patroas, sindicato, federação e tudo. Então nós acompanhamos. $\mathrm{E}$ então, quando elas conseguem, vem a Reforma Trabalhista! E o que nós estamos discutindo? Até onde a Reforma Trabalhista vai atingir as trabalhadoras domésticas nesses seus direitos?

Assiste-se o traçar de um caminho, sobretudo para as trabalhadoras domésticas, que é o seguinte: historicamente marginalizado em relação ao emprego "tradicional", o reconhecimento social e jurídico do trabalho doméstico e de cuidado tardou para acontecer, tendo sido conquistado em 2013, com uma refratária regulamentação em 2015; quando isso aconteceu, porém, veio seguido por uma reforma trabalhista e um período de desemprego crescente e altas taxas de informalidade ${ }^{131}$, de modo que grande parte das conquistas parecem escorrer pelas mãos e os serviços públicos essenciais, erguidos como castelos de cartas por conta de investimentos insuficientes, estão prestes a ruir.

\footnotetext{
${ }^{131}$ No trimestre de dezembro de 2017 a fevereiro de 2018, o IBGE registrou crescimento no índice de desemprego, que chegou a $12,6 \%$, e o menor número de trabalhadores registrados desde 2012, computandose 10,8 milhões de trabalhadores sem carteira assinada (IBGE, 2018).
} 
Em vista de todo o exposto ao longo deste capítulo, foi possível ver as intensões dos legisladores na formulação das normas referentes ao cuidado hoje vigentes e todos os problemas que elas carregam. A defasagem entre previsão legal e aplicação fática de algumas normas, como é o caso das creches, bem como as cargas sociais e sexistas de outras, como é o caso da regulação do emprego doméstico, tiram a credibilidade do Direito do Trabalho nacional. Diante dessa realidade, resta saber como as integrantes das organizações de trabalhadoras domésticas e de movimentos feministas interpretam essa realidade e se as reivindicações por avanços no campo juslaboralista ainda fazem sentido na busca por maior igualdade. A apresentação desses dados e a reflexão sobre as respostas do campo serão objeto do próximo capítulo. 


\section{CAPÍTULO 4 \\ ROMPIMENTO E RECONSTRUÇÃO DE ALICERCES}

Formado o arcabouço teórico da tese, a partir dos estudos sobre o cuidado e as reflexões teóricas feministas sobre o Direito do Trabalho, e apresentado o panorama sobre o modelo brasileiro de organização do cuidado e das normas trabalhistas relativas ao tema, a proposta para este capítulo é colocar em diálogo a prática social com os resultados até agora identificados, buscando captar como movimentos e organizações sindicais e de mulheres do país enxergam e demandam do ordenamento jurídico quando articulados trabalho e cuidado.

Como dito no item dedicado à Metodologia, se são os movimentos de mulheres que desde o final dos anos 1970 reivindicam a socialização do trabalho doméstico e o reconhecimento do trabalho de cuidado como arrimo do sistema capitalista - inclusive, como visto, com papel de destaque em momentos cruciais da organização jurídica do país, como a Assembleia Nacional Constituinte -, dialogar com suas integrantes para conhecer sua leitura sobre a melhor forma de avançar nessas questões e sobre o papel que o Direito pode desempenhar nesse processo é não apenas evidente como necessário, a fim de abrir esta pesquisa para a compreensão das potencialidades e limitações da disciplina como instrumento para a igualdade de gênero. As respostas colhidas serão apresentadas a seguir.

\subsection{MARCAS DA SEGREGAÇÃO ENTRE TRABALHO E CUIDADO ${ }^{132}$}

As interlocutoras desta etapa da investigação pertencem a grupos selecionados, com inserção social relevante e demandas relativas à temática do cuidado e de trabalho das mulheres, mas diferem em termos de pressupostos políticos, da origem e formação de suas integrantes, o que se reflete nas reivindicações formuladas por cada um. Os grupos, já identificados anteriormente, são: Federação Nacional das Trabalhadoras Domésticas -

\footnotetext{
${ }^{132}$ Resultados parciais deste item foram apresentados no $41^{\circ}$ Encontro Anual da ANPOCS, no formato de comunicação individual, e, posteriormente, publicado nos anais do evento. Graças às contribuições das professoras Bila Sorj, Arlene Martinez Ricoldi e Moema de Castro Guedes, e à profícua conversa com Fabiana Sanches Grecco na mesma ocasião, foram delineados os rumos da análise deste capítulo.
} 
FENATRAD; Sindicato das/os Trabalhadoras/es Domésticas/os de Campinas e Região; Sindicato dos Trabalhadores Domésticos do Município de São Paulo - STDMSP; Federação Nacional dos Enfermeiros - FNE; Associação dos Cuidadores de Idosos da Região Metropolitana de São Paulo - ACIRMESP; Marcha das Margaridas; SOS Corpo Instituto Feminista para Democracia; e Sempreviva Organização Feminista - SOF.

Ainda que o trabalho de cuidado atribuído às mulheres seja tema comum a todos esses grupos, em especial o trabalho doméstico remunerado ou não remunerado, as organizações profissionais de empregadas domésticas, a federação de enfermeiras e associação de cuidadoras de idosos têm como prioritárias, em sua agenda política, pautas que envolvem o reconhecimento e garantias de direitos para as categorias, enquanto as organizações feministas demonstram preocupações que englobam, de modo mais claro, os debates sobre opressão de gênero e divisão sexual do trabalho.

O primeiro resultado relevante das entrevistas diz respeito à articulação feita pelos grupos estudados entre a luta por direitos trabalhistas e por direitos das mulheres. Foi observado que, na percepção da maioria das entrevistadas, o Direito do Trabalho é entendido como assegurador do contrato de trabalho e das garantias a ele vinculadas, como previdência social e seguro desemprego. Assim, em especial no âmbito das organizações profissionais, por mais que a opressão de gênero - e de raça - seja uma preocupação, ela parece de certa forma apartada dos debates trabalhistas.

No caso da presidenta da FENATRAD, Creuza Oliveira, por exemplo, ainda que ela considere que as demandas da entidade abarcam um campo amplo, no qual estão inseridas "também" reivindicações por escolas e creches, ela distingue essas pautas dos direitos trabalhistas. Em suas palavras:

Eu sempre coloco que a luta das trabalhadoras domésticas não é só por reposição salarial, por data base, até porque a gente não tem data base. A nossa luta é mais ampla, pelo fato de nós sermos mulheres e sermos negra. (...) Então a gente luta também pela questão da educação, luta por creche, porque nós sabemos a importância de creches em período integral para que as mulheres possam trabalhar com segurança. A gente pode até dizer que a luta pelos direitos trabalhistas é nossa principal bandeira, mas existem diversas outras bandeiras (OLIVEIRA, 2016).

Quando perguntada sobre as mudanças no Direito que a Federação pleiteia, Creuza afirmou que "a gente luta pela equiparação de fato". Suas críticas foram direcionadas especialmente à Emenda Constitucional 72/2013 e à Lei Complementar 
150/2015, como retratado no capítulo anterior (OLIVEIRA, 2016). Com relação à necessidade de creches para as trabalhadoras domésticas, disse que "nossa luta tem sido, com certeza, por creches em período integral". Ela explica que a FENATRAD participa também do movimento de luta por creches, "junto ao movimento de mulheres", frisando que "a gente tem que brigar para o Estado garantir creches públicas. E as empresas ricas, assim como as faculdades privadas, têm que bancar creche, sim, para as trabalhadoras da sua empresa" (OLIVEIRA, 2016).

Para a presidenta do Sindicato dos Trabalhadores Domésticos do Município de São Paulo, Silvia Santos, a reivindicação do sindicato é pela equiparação da categoria e a efetivação dos direitos conquistados em 2013. Desse modo, consoante a presidenta, "o importante mesmo que veio foi o FGTS, essa parte de seguro desemprego, que ajuda, mas ainda têm coisas necessárias para se equiparar com as outras profíssões", o que ela exemplifica com a licença-maternidade, que considera não cobrir as trabalhadoras domésticas nas mesmas condições. As garantias do contrato de trabalho são centrais no seu discurso, justificado com o seguinte exemplo: “eu vejo minha mãe, ela trabalhou quarenta anos com a mesma família e voltou para casa, com uma mão na frente e outra atrás, andando, porque ela não tinha dinheiro nem para a passagem” (SANTOS, 2017).

No caso da presidenta da Associação dos Cuidadores de Idosos da Região Metropolitana de São Paulo, Lídia Nadir Giorge, a divisão entre reivindicações trabalhistas e de mulheres é bastante evidente. Ela tem a percepção de que "as cuidadoras sempre foram as mulheres", o que significa que "para as cuidadoras serem cuidadoras de outras pessoas, elas largam as famílias delas aos cuidados dos vizinhos e dos amigos”. Partindo disso, porém, ela diz que a luta da associação é para regular a profissão de cuidadora e cuidador e, assim, garantir a profissionalização, pois "a gente precisa ter uma profissão mais humana" (GIORGE, 2017).

Com relação às principais reivindicações da Federação Nacional dos Enfermeiros, a presidenta Solange Aparecida Caetano (2017) dá destaque à regulamentação da jornada reduzida de 30 horas semanais e ao piso salarial nacional, ambas medidas que visam à valorização da categoria no país. Em apartado, ela menciona as pautas relativas à "saúde da mulher", que incluem o esforço da FNE na inserção de “cláusulas nas convenções coletivas para dispensa da profissional pelo menos uma vez ou duas a cada seis meses para ela fazer os exames preventivos de câncer de útero e câncer 
de mama", bem como a preocupação com o trabalho das gestantes em local insalubre, combate ao assédio moral (CAETANO, 2017).

Ao problematizar "o fato de as mulheres não terem creche para deixar os seus filhos, apesar de receberem auxílio creche, em muitos lugares o valor recebido não é o suficiente para colocar suas crianças em creches decentes", Solange caracteriza o direito à guarda de filhas e filhos como "direto das mulheres", afirmando haver uma resistência extremamente grande entre os sindicatos patronais que negociam com os profissionais da enfermagem “em relação a ampliar o que é direito das mulheres” (CAETANO, 2017).

Para a coordenadora da Marcha das Margaridas, Alessandra Lunas, as especificidades do trabalho no campo - muito diverso à realidade do trabalho urbano deixam claras as assimetrias entre as trabalhadoras e os trabalhadores dentro das famílias. Ela explica que:

\begin{abstract}
As assalariadas rurais ainda estão com muita defasagem com relação aos homens, os direitos em geral não são reconhecidos da mesma forma. Por exemplo, se uma família trabalha em uma propriedade de criação de gado, geralmente quem é contratado é só o homem. Ninguém fica em uma fazenda, em lugares longínquos, sozinho. Se ele tem família, tem filho que já consegue ajudar na lida do gado, isso conta muito na hora da contratação. Só que quem é contratado é o homem, a mulher e os filhos também vão exercer um trabalho, mas sem direito garantido. Visibilizar o trabalho dessas mulheres assalariadas rurais é um grande desafio, demanda outros olhares e a necessidade de ter uma compreensão diferenciada nas negociações coletivas (LUNAS, 2017).
\end{abstract}

Ainda assim, a luta por creches também parece estar apartada do debate de direitos trabalhistas das mulheres do campo, pois ela diz que "a gente tem trazido a questão do cuidado, a luta pelas creches rurais, para todo o processo, inclusive de inclusão das mulheres no processo produtivo". Alessandra complementa que a "autonomia dessas mulheres ainda é muito comprometida no campo, e isso tem a ver com criar estratégias para a gente discutir com essas mulheres os seus direitos, principalmente o de uma vida mais digna" (LUNAS, 2017).

Para Nalu Faria, integrante da Sempreviva Organização Feminista, as creches são uma "reivindicação feminista", no sentido de que não se limitam à questão da educação da criança, por incidir no trabalho doméstico executado pelas mulheres de cuidado dos filhos. Sem tangenciar qualquer pauta das garantias trabalhistas, ela entende que a pauta do cuidado passa pela socialização desse tipo de trabalho, "que tem que ser 
assumido pelo Estado", mas também por "uma dimensão mais geral de como a sociedade tem que se organizar e criar outras alternativas para a dimensão do trabalho" (FARIA, 2017).

Na fala da Maria Betânia Ávila, integrante do SOS Corpo - Instituto Feminista para a Democracia, também parece haver certa distinção entre o que são reivindicações trabalhistas e o que são reivindicações por direitos das mulheres. Em suas palavras:

A gente defende os direitos trabalhistas não só ligados às categorias domésticas remuneradas, não. A gente defende mais amplamente não só a questão das trabalhadoras urbanas, mas também das trabalhadoras rurais, temas como direito à terra, direito ao crédito, a questão das jornadas de trabalho. A questão da creche é uma luta mais localizada com os movimentos de mulheres populares. A gente tem trabalhado muito com a questão das creches, na medida em que a luta pelas creches é muito importante nos níveis locais (ÁVILA, 2017).

As entrevistas indicam uma apreensão do Direito como ferramenta para avançar na melhoria da vida das mulheres trabalhadoras, mas fica evidente que, para as interlocutoras, ele não é uma resposta em si, deixando muito a desejar. Isso se reflete na fala de Creuza Oliveira, da FENATRAD, reproduzida abaixo:

A mulher que trabalha durante o dia e estuda a noite, muitas vezes tem que abrir mão do estudo, porque não tem creche nas universidades onde ela possa deixar seus filhos. (...) As domésticas, que saem para trabalhar e quase não tem creche onde deixar seus filhos. São várias as situações em que a legislação não protege as mulheres e o Estado não garante políticas publicas para a população, especialmente para as mulheres, de serviços públicos (OLIVEIRA, 2016).

Para Eliete Silva (2017), do sindicato de Campinas, a resposta legal, muitas vezes, traz piora nas condições de trabalho das mulheres, o que ela exemplifica com o aumento da informalidade e das condições de trabalho das domésticas em sua região depois de promulgada a Lei Complementar 150/2015, como mencionado no capítulo anterior. Na perspectiva das enfermeiras, apresentada por Solange Caetano (2017), o Direito do Trabalho não contempla as especificidades do trabalho de cuidado com o paciente, por ser "muito focado nas normas, nas regras, que são utilizadas de forma geral".

A percepção de Silvia Santos, do STDMSP, é um pouco mais favorável ao Direito, que ela entende que "ajudou muito" as trabalhadoras domésticas. Ainda assim, ela afirma que a situação está longe do ideal e que há obstáculos para que as leis 
trabalhistas sejam de fato aplicadas, sobretudo a falta de divulgação. Em suas palavras, “os patrões ainda não entendem direito e não aceitam; os funcionários não sabem se impor para cobrar seus direitos; muitos não tem a informação. Falta muito para equiparar a outras áreas" (SANTOS, 2017).

Para Lídia Nadir Giorge, da ACIRMESP, “(...) as leis não contemplam nem cuidadores nem contratantes: porque não é uma empresa e na empresa é mais fácil". Ela diz que é impossível aplicar as mesmas regras trabalhistas a um empregado de uma empresa e a uma cuidadora no ambiente doméstico. Ela diz que o direito precisa ser sensível à realidade de quem cuida de pessoas, pois, por exemplo "não dá para bater cartão na entrada e na saída, com uma hora de almoço", uma vez que nunca se sabe a necessidade da pessoa cuidada naquele exato momento (GIORGE, 2017).

Nalu Faria, da SOF, vai além neste debate, afirmando que "o campo do reconhecimento dos direitos, dentro de um determinado modelo, encontra um limite que é o limite daquele modelo. Para você ir mais além, tem que ter outro modelo". Assim, por ver a necessidade de redimensionar as relações sociais e econômicas, o conceito de direitos deveria acompanhar esse redimensionamento (FARIA, 2017). Também na linha crítica ao Direito, Maria Betânia Ávila, da SOS Corpo, ressalta que

os direitos trabalhistas precisariam ser muito ampliados para responder as necessidades dos trabalhadores, mas, sobretudo, das trabalhadoras. Os que nós ainda temos não contemplam essa relação trabalho produtivo e reprodutivo, eles são todos instituídos tendo as mulheres como provedoras do trabalho reprodutivo (ÁVILA, 2017).

Entretanto, o uso da expressão "os que nós ainda temos", revela uma guinada na forma de muitas dessas entidades se posicionarem publicamente em relação ao Direito do Trabalho - e aos direitos sociais como um todo. Frente à reforma trabalhista e demais investidas do governo Temer contra os direitos sociais, abordadas anteriormente, a defesa das garantias constitucionais e legais têm sido a estratégia adotada pelos movimentos, com o discurso de evitar retrocessos. A fala de Maria Betânia Ávila (2017) esclarece essa escolha:

(...) o nosso drama agora é que, mesmo com as suas restrições, estão querendo que estes direitos sejam destruídos. A gente se vê em um momento de lutar para que eles permaneçam, com uma luta de resistência, para depois eles avançarem. Não que a luta esteja separada, mas nesse momento uma questão crucial é garantir o que já conquistamos, na perspectiva de ampliação daqui para frente. 
Alinhando-se a essa postura, Alessandra Lunas, da Marcha das Margaridas, deixa claro estar preocupada com os efeitos que as tais reformas podem causar na vida das trabalhadoras do campo:

(...) nesse momento que estamos vivendo, a principal luta que a gente vem fazendo é principalmente se posicionar contra todos os retrocessos que estão sendo impostos às vidas das mulheres, como a PEC 55, que impõe o congelamento dos gastos nos recursos das questões sociais, porque isso impacta diretamente na vida das mulheres. Não só o congelamento dos gastos, mas a reforma da previdência, todo esse processo que é um tripé fundamental da Seguridade Social. Foram conquistas da Constituição de 1988, que fizeram muita diferença para a vida de muitas mulheres, mas que ainda não são unânimes e que a gente continuava lutando para que todas tivessem acesso. (...) Então, congelar os gastos de saúde e educação é dizer para as mulheres "vocês vão retroceder e voltar para dentro de casa". (...) Nesse momento, nossa resistência é principalmente contra os retrocessos, contra a visão conservadora do Congresso Nacional, que também tem trazido várias coisas para a pauta que leva ao retrocesso na vida das mulheres (LUNAS, 2017).

Luiza Ferreira, da FENATRAD, afirma que esse é o momento de "continuar a luta”, não só pelas trabalhadoras domésticas, mas para todas as trabalhadoras e trabalhadores. Segundo ela:

Sabemos que essa reforma trabalhista foi feita apenas para beneficiar o empregador. Apesar de que existe trabalhador que só de saber que aquele imposto sindical não vai mais ser descontado do salário dele, ele diz que foi ótimo. Só que ele não sabe que os direitos que ele tinha antes da reforma não foram fruto de uma luta individual dele, foi uma luta coletiva. Mesma coisa a trabalhadora doméstica. Os direitos que estão hoje conquistados para a categoria não contemplaram muitas das diretoras que estão nos sindicatos, porque são pessoas com mais de 60 anos, como é o meu caso. Nem por isso a gente deu um passo atrás e disse 'não, a gente já garantiu o nosso e não vamos lutar para garantir para mais ninguém'. Não, a luta continua, para garantir o que já conquistamos e possivelmente para ampliar (FERREIRA, 2018).

As falas aqui apresentadas permitiram verificar que o Direito do Trabalho é, sim, articulado nas reivindicações de mulheres mobilizadas em torno de pautas de cuidado, tanto nos movimentos feministas quanto nas organizações profissionais entrevistadas. Entretanto, constatou-se que, na maioria das vezes, a esfera trabalhista é tratada como uma esfera apartada dos debates de cuidado e socialização do trabalho doméstico. Estes, por sua vez, são mais comumente entendidos na chave das reivindicações por políticas 
públicas para as mulheres, ou como direitos das crianças, como é o caso das demandas por ampliação das vagas em creches públicas e escolas em tempo integral.

Consoante Maria Betânia Ávila (2016, p. 144), o "grau de informação e de consciência de direitos da categoria de empregadas domésticas é uma dimensão estratégica de sua ação política”, enquanto que,

\begin{abstract}
para o movimento feminista, o desafio político é fazer a crítica a essa relação de trabalho, lutar pela sua superação e ao mesmo tempo enfrentar a incontornável necessidade de apoio à luta das trabalhadoras domésticas por direitos trabalhistas. $\mathrm{O}$ que nos coloca a questão da interdependência entre direitos, processo de transformação social e emancipação. A questão do trabalho doméstico remunerado e das mudanças que ocorrem na sua reconfiguração deve ser analisada a partir de seu significado na reconfiguração da divisão sexual do trabalho, considerando que o avanço nos direitos das empregadas domésticas acirra contradições nas relações sociais de sexo/gênero no espaço doméstico (ÁVILA, 2016, p. 145).
\end{abstract}

Nesse sentido, o Direito do Trabalho fica, na maioria das vezes, restrito às reivindicações relativas ao mercado de trabalho, abarcando o reconhecimento e valorização das profissões que envolvem trabalho de cuidado - como é o caso dos projetos de lei referentes à regulamentação da profissão de cuidadora, diversas vezes mencionados na fala de Lídia Giorge (2017), da ACIRMESP -, ou o pleito por garantias legais, por exemplo, a limitação de jornada para trabalhadoras domésticas, vista na mobilização em torno da Emenda Constitucional n. 72/2013, ou a redução de jornada para as profissionais de enfermagem.

Logo, a análise das entrevistas demonstrou que, em termos instrumentais, as normas trabalhistas respondem muito pouco ao universo que produz, pratica e evoca as categorias "trabalho" e "cuidado", estando atreladas predominantemente à esfera pública e ao trabalho produtivo remunerado. $\mathrm{Na}$ perspectiva jurídica, as respostas do campo apontam para os limites do Direito do Trabalho enquanto ferramenta para conquistar avanços sociais na seara do cuidado, mas não exatamente por suas fronteiras, que não consideraram o "trabalho como cuidado", como seria a conclusão lógica das reflexões feministas internas à disciplina. Absorvendo as lições de Joanne Conaghan (2005, p. 42), “concentrar-se apenas naquelas relações que a lei reconhece como econômicas e trabalhistas é permitir que a forma jurídica modele a agenda normativa em vez de a agenda normativa (re)moldar a forma legal". 
Na verdade, incluir o cuidado ao Direito do Trabalho nos seus moldes vigentes e na atual conjuntura seria, no mínimo, desastroso. Afinal, significaria restringir muito o âmbito de aplicação de garantias ligadas à socialização do cuidado e à valorização do trabalho doméstico, remunerado ou não, se elas fossem vinculadas a direitos que amparam somente 36\% das mulheres ocupadas (IPEA, 2016, p. 3), já que o Direito do Trabalho se limita a regular o trabalho subordinado, a relação de emprego.

Desse modo, separar trabalho e cuidado em termos jurídicos significa, para os movimentos e organizações, que as pautas relativas ao cuidado podem ser atreladas a direitos universais, ou seja, ultrapassando a noção de cidadania regulada pela carteira de trabalho (SANTOS, 1979). Com efeito, as entrevistas revelaram ser, estrategicamente, mais efetivas em falar dos "direitos das crianças", ou até mesmo dos "direitos das mulheres", do que tratar dos direitos trabalhistas. Isso mesmo diante dos novos desafios que foram elencados por algumas das entrevistadas, em que se assumem posturas defensivas em relação aos direitos conquistados, pois ainda assim as garantias relativas ao cuidado são postuladas para todas e todos.

Dessa maneira, é preciso pensar em novas respostas jurídicas que permitam articular trabalho e cuidado e que sejam universais, de modo que não se criem margens e rótulos sobre quem é mais ou menos cidadão, mais ou menos trabalhador, mais ou menos sujeito de direito. Não é mais possível, no mesmo raciocínio, vincular as garantias previdenciárias para a velhice aos salários recebidos ao longo da vida produtiva formalizada, ou contar com contribuições sociais de trabalhadoras e trabalhadores cujos salários vem sendo progressivamente achatados enquanto a exploração cresce.

Assim, o acesso ao mercado de trabalho, a salários legalmente igualitários e a garantias vinculadas ao vínculo empregatício não são mais - e possivelmente nunca foram - uma resposta para combater a desigualdade de gênero, tampouco de raça e de classe. É preciso investir em "uma visão modificada de cidadania, cuidado e trabalho em si” (BERNSTEIN, 2006, p. 228), o que demandará esforços para que sejam repensadas as estruturas sociais e, considerando o recorte desta tese, a reformulação do escopo da disciplina jurídico-trabalhista, o que tentarei esboçar na sequência. 


\subsection{VIAS PARA REFORMULAÇÃO DO ESCOPO DA DISCIPLINA}

As reflexões apresentadas na tese até este momento seguem a seguinte linha de raciocínio: as teorias feministas relativas ao cuidado mostram que trabalho é cuidado, mas a transposição dessa compreensão ao Direito do Trabalho é impedida devido à falsa neutralidade dos pressupostos da disciplina, somado à sua cobertura restrita diante dos fatores socioeconômicos da realidade brasileira, fatores que contribuem para a escolha dos movimentos sindicais e das organizações de mulheres por tratar cuidado e trabalho como esferas apartadas da luta por direitos, porque pretendem que as conquistas relativas ao debate do cuidado sejam universais.

Não se pode negar o mérito do Direito do Trabalho por ter conseguido atingir seu objetivo protecionista original de "atenuar e compensar significativamente a situação de debilidade económica e jurídica dos trabalhadores subordinados" (RAMALHO, 2000, p. 17). Entretanto, ao longo do estudo aqui desenvolvido, restou evidenciado que esse objetivo se tornou demasiadamente limitado, uma vez que este trabalhador tutelado pelas normas trabalhistas é exceção no mercado de trabalho, o que exige repensar o escopo da disciplina e buscar novos alicerces jurídicos que sejam páreo para a conjuntura de exploração e opressão atualmente delineada.

Reitero que em momento algum esta tese flerta com o argumento fácil de que o Direito do Trabalho estaria ultrapassado num mundo global e automatizado, em que as pessoas são impelidas a se transformar em "empreendedoras de si mesmas" (GEORGES, 2017, p. 131), mas não é possível fechar os olhos para o fato de que a irreversibilidade das condições por ele delimitadas se revelou contraproducente à meta de universalidade de seu estatuto protetivo (RAMALHO, 2000, p. 17), tampouco em insistir na "nostalgia do fordismo" (BRAGA, 2003). Nesse sentido, é preciso pensar em como romper o fosso criado entre pessoas integradas e não integradas no sistema de tutela laboral (RAMALHO, 2000, p. 17-18).

Por mais que Amélia Cohn (2000, p. 398-399) narre o processo que fez com que não mais prevaleça no Brasil o padrão de integração social pautado pela inserção no mercado de trabalho formal ${ }^{133}$, mas sim via consumo ${ }^{134}$, a perspectiva de gênero permite

${ }^{133}$ A respeito da formação histórica da cidadania pautada no trabalhismo, cf.: GOMES, 2005. 
enxergar que a cidadania ainda está amplamente ligada ao trabalho, do que decorre que, sem o reconhecimento do cuidado como trabalho, suas provedoras continuam com acesso restrito à cidadania plena (DAMAMME ; HIRATA ; MOLINIER, 2017, p. 12). Ademais, os mecanismos sociais que fazem esconder a quantidade de cuidado necessária para que um indivíduo viva de forma "independente" reforçam um ideal de cidadão que exclui pessoas rotuladas como exclusivamente receptoras do cuidado, como idosos e portadores de deficiência (DAMAMME; HIRATA; MOLINIER, 2017, p. 12).

São justamente essas considerações sobre o modelo de cidadania e os fatores que levam à inclusão ou exclusão social que, aparentemente, podem dar pistas para a reformulação do escopo do Direito do Trabalho aqui procurado. Seguindo a lição de Roberto Lyra Filho (1993, p. 74), de que a posição de jurista não é só a de "conhecer e interpretar os sistemas de normas", mas sim de "contribuir para que elas sejam transformadas, na direção dos movimentos jurídicos reivindicatórios de classes espoliadas e grupos oprimidos", os próximos itens buscarão dar os primeiros passos na busca pelas vias aqui investigadas.

\subsubsection{Justiça, responsabilidade e dependência}

A ideia de justiça permeia os estudos de gênero, uma vez que, de uma forma ou outra, eles se pautam na injustiça configurada a partir da opressão das mulheres inseridas em um sistema forjado pela lógica capitalista e patriarcal. Ainda que a definição do que vem a ser justiça na compreensão feminista não seja o foco de análise de todas as estudiosas debruçadas sobre o tema, é inevitável partirem do pressuposto de que justiça não se limita aos conceitos teóricos construídos até então, permeados de padrões masculinos e ideais universais que não foram desenhados para a vida das mulheres.

Nesse sentido, Nancy Fraser (2002, p. 67) afirma que "a justiça requer acordos sociais que permitam que todos os (adultos) membros da sociedade interajam uns com os outros como pares" e, portanto, não é passível de ser alcançada em sistemas nos quais a distribuição de recursos materiais não garantam a independência a seus participantes e os modelos culturais não expressem mesmo respeito a todos. Logo, "os modelos de valores

\footnotetext{
${ }^{134} \mathrm{O}$ quadro da inclusão pelo consumo foi descrito também por Lena Lavinas, como brevemente abordado no item 3.5 desta tese. Para aprofundamento, cf.: LAVINAS, $2017 \mathrm{~b}$.
} 
institucionalizados que, sistematicamente, depreciam algumas categorias de pessoas e as qualidades a elas associadas" precisam ser repensados (FRASER, 2002, p. 67).

Nessa tarefa, considerando a bagagem acumulada até este ponto da tese, a perspectiva do cuidado pode ser bastante útil, pois ela permite melhor compreender a origem da separação feita pela teoria da justiça, clássica ou moderna, que coloca as questões de justiça restritas à esfera pública, enquanto a esfera privada, resguardada pela retórica da não intrusão da intimidade, é considerada um domínio à parte, deixando de fora do escopo da justiça as regras sociais que regem a divisão sexual do trabalho na família (BENHABIB, 2002, p. 109).

Assim, Susan Moller Okin (1989, p. 8, tradução nossa), retomando as noções de cuidado de Joan Tronto e buscando fazer avançar a noção de ética de Carol Gilligan abordadas no capítulo 1 -, critica teorias da justiça contemporâneas ${ }^{135}$, hegemônicas, que se pretendem "inclusivas" em comparação à teoria de Rawls, mas que continuam com a “mesma tradição de 'esferas separadas, ignorando a família, sua divisão do trabalho e, a isso relacionadas, a dependência econômica e as oportunidades restritas da maioria das mulheres". A autora destaca que o "indivíduo" que forma a bases para tais teorias é o chefe de família de um lar patriarcal, o que significa que dificilmente considerou-se que os princípios da justiça delineados por elas fossem aplicados a mulheres ou a relações entre os sexos (OKIN, 1989, p. 14).

Por conseguinte, Okin (1989, p. 9) afirma que a principal negligência de muitos teóricos da justiça é tomar seres humanos maduros e independentes como sujeitos das teorias, esquecendo-se que eles são resultado de um processo que envolve trabalho pesado e atenção, em grande parte assumido pelas mulheres. Dessa forma, ela defende que as teorias da justiça devem ser aplicadas a todos, "ao invés de assumir silenciosamente que metade de nós cuida de áreas inteiras da vida que são consideradas como externas ao escopo da justiça social", concluindo que:

Penso que a distinção entre uma ética da justiça e uma ética do cuidado foi superada. A melhor teoria sobre a justiça, defendo eu, integra em si as noções de cuidado e empatia, de pensar nos interesses e no bem-estar de outros que podem ser muito diferentes de nós mesmos. Por conseguinte, é um engano estabelecer uma dicotomia como se fossem duas éticas contrastantes. A melhor teoria sobre a justiça não é uma "visão de lugar nenhum", mas resulta da cuidadosa e atenta consideração do ponto de vista de todos. Isso significa, é claro, que a

${ }^{135}$ Sua crítica dirige-se diretamente a Bruce Ackerman (1980) e Ronald Dworkin (2010). 
melhor teoria sobre a justiça não é boa o suficiente se não, ou não puder ser adaptada para, incluir mulheres e seus pontos de vista tão plenamente quanto inclui homens e seus pontos de vista (OKIN, 1989, p. 14-15, tradução nossa). ${ }^{136}$

Em termos concisos, a proposta de Okin envolve unir a perspectiva da justiça à ética do cuidado, ética que "está associada a uma forte ideia de responsabilidade", relativa não apenas às relações interpessoais, mas podendo envolver também relações entre entidades coletivas, já que "relações particulares de cuidado constituem uma base sólida para compreender o que significa a responsabilidade no plano mundial" (MOLINIER; PAPERMAN, 2015, p. 47-48). Segundo Pascale Molinier e Patricia Paperman (2015, p. 47-48), pensar a responsabilidade em termos relacionais tira o foco da ação individual e permite colocar no centro da análise as questões das desigualdades de poder e das assimetrias de responsabilidades, abrindo a possibilidade de considerá-las como inerentes às tensões e às dinâmicas das múltiplas relações em que se inserem as partes.

Logo, a concepção relacional de responsabilidade, diferente do modelo jurídico de responsabilidade, "supõe que as relações sejam sempre parciais, distendidas, múltiplas, mutáveis, conflituosas, assimétricas, entre diferentes tipos de protagonistas, em variados níveis” (MOLINIER; PAPERMAN, 2015, p. 49). No cerne dessa compreensão está o cuidado, pois ainda que suas relações se estabeleçam socialmente, com suas tensões e conflitos, a atribuição da responsabilidade por elas não é feita publicamente nem de modo democrático. A pergunta "quem cuida de quem e como?" revela a dificuldade de reconhecimento das relações que ligam pessoas a outras pessoas, empresas, Estados, relações essas que se estabelecem e relevam uma interdependência quase sempre assimétrica (MOLINIER; PAPERMAN, 2015, p. 49).

Nesse sentido, Flávia Biroli (2013, 1. 52\% cap. 5) argumenta que o peso dado pelo liberalismo e neoliberalismo "às escolhas pessoais e à responsabilidade dos indivíduos por essas escolhas corresponde, no limite, ao silêncio sobre as posições relativas de poder e a dominação". Segundo ela, um dos problemas dessa perspectiva é

\footnotetext{
${ }^{136}$ Excerto original: "I think the distinction between an ethic of justice and an ethic of care has been overdrawn. The best theorizing about justice, I argue, has integral to it the notions of care and empathy, of thinking of the interests and well-being of others who may be very different from ourselves. It is, therefore, misleading to draw a dichotomy as though they were two contrasting ethics. The best theorizing about justice is not some abstract "view from nowhere," but results from the carefully attentive consideration of everyone's point of view. This means, of course, that the best theorizing about justice is not good enough if it does not, or cannot readily be adapted to, include women and their points of view as fully as men and their points of view".
} 
que ela exclui questões relativas à interdependência, deixando à sombra "processos sociais e arranjos institucionais que definem posições relativas para pessoas, restringindo ou ampliando suas opções”, o que as expõe a uma maior ou menor vulnerabilidade.

A autora continua, afirmando que a ênfase na responsabilidade individual acaba por reforçar discursos que tratam a dependência como, por um lado, um desvio - quando envolve indivíduos adultos e dentro do que se considera "normalidade" física e mental e, por outro lado, como um problema privado - quando abarca indivíduos que necessitam do cuidado de outros de maneira sistemática, como as crianças, os idosos e portadores de deficiência (BIROLI, 2013, 1. 60\% cap. 5). Esta oposição entre dependência e responsabilidade pessoal se ancora em uma compreensão da esfera doméstica e familiar não só como distinta, mas como "largamente independente das esferas da política e do mercado", como se resultasse de escolhas independentes das normas e arranjos institucionais e das formas de concentração de poder (BIROLI, 2013, 1. 60\% cap. 5).

Em síntese, Biroli (2013, 1. 90\% cap. 5) explica que colocar em oposição "responsabilidade pessoal" e "dependência" impede que os problemas relativos a esta última sejam tratados como questões políticas e de justiça. Ela reafirma que "as formas incontornáveis da dependência são permanentes no ciclo de vida dos indivíduos e fazem parte das relações que se estabelecem entre eles", de modo que quando ignoradas por normas e práticas sociais validadas apenas em situações hipotéticas - "se todos fossem adultos, se todos fossem iguais na sua capacidade de trabalho e se todos tivessem um ponto de partida igual nos recursos para a construção das suas vidas" - o cuidado é relegado (BIROLI, 2015, p. 112). Por esse motivo, a autora defende o deslocamento da noção de responsabilidade individual para a de responsabilidade compartilhada (BIROLI, 2013, $1.90 \%$ cap. 5).

O caminho percorrido até aqui leva até o modo de pensar responsabilidade de Iris Marion Young (2005, p. 709), a partir do que ela denominou "modelo de conexão social" (social connection model of responsibility). Nas palavras da autora, "nossa responsabilidade deriva do fato de pertencermos, juntos com outros, a um sistema de processos interdependentes de cooperação e competição, por meio do qual procuramos benefícios e buscamos realizar nossos projetos" (YOUNG, 2011, p. 105).

Para explicar seu modelo de responsabilidade enquanto conexão social, ela lança mão do exemplo de um movimento contra oficinas com trabalho precarizado 
(sweatshops) nos Estados Unidos, que reivindicou das empresas que compram roupas a granel dessas fábricas e revendem com sua logomarca que elas assumissem a responsabilidade pelas condições precárias sob as quais tais peças foram produzidas e convidou os consumidores a fazerem o mesmo (YOUNG, 2005, p. 713). Young (2005, p. 713) explicou que para muitas instituições e indivíduos é absurda a ideia de que compradores e revendedores se responsabilizem pela exploração do trabalho em fábricas, muitas vezes, de outros países, restringindo a culpa aos donos e gerentes desses locais.

Estendendo o raciocínio, Pascale Molinier e Patricia Paperman (2015, p. 50) perguntam:

(...) que europeu, ao comer uma banana, preocupa-se em saber em que condições sociais ela foi cultivada e que tradição de sangue, violência e exploração está envolvida, por exemplo, na agricultura latinoamericana? Mesmo não tendo certamente desejado essa violência, pela qual ele não é a priori responsável, o consumidor é parte integrante dela, pois a banana o liga às condições de vida dos agricultores que a cultivaram. Desse ponto de vista, não há muita diferença entre o consumidor de bananas e o de cocaína.

Colocar o foco na responsabilidade compartilhada é romper com a ideia de indivíduo autônomo, abstrato e isolado presente na teoria, seja filosófica, econômica ou jurídica. Não é possível ignorar as conexões entre pessoas, de pessoas com instituições e de pessoas com o Estado. Nenhum ser humano é independente em si, ainda que não seja socialmente rotulado como independente, de modo que a necessidade de cuidado é parte de nossa vida e, portanto, cuidar dos outros é trabalho socialmente essencial e que beneficia a todos, sendo, da mesma maneira, responsabilidade de todos.

Nesse sentido, volta a ser relevante a perspectiva de cuidado de Joan Tronto (2003, p. 9), como noção que pode servir tanto como valor moral quanto como conquista política para uma sociedade melhor. Partindo dessa proposição, a autora questiona a divisão entre dependência e autonomia e propõe uma reflexão em torno da ideia de interdependência, a partir da qual ela enfatiza que todos os seres dependem do cuidado para existir, intercalando momentos da vida em que recebem ou oferecem cuidado (TRONTO, 2003, p. 162). Por conseguinte, “todos somos vulneráveis, somos todos responsáveis" (HIRATA, 2014b, p. 31).

Nesse caminho, Pascale Molinier (2017, p. 189), dialogando com Tronto, afirma que distinguir aqueles que precisam de cuidado daqueles que não precisam ignora a 
vulnerabilidade comum compartilhada por todos os seres humanos ${ }^{137}$, pois cada um de nós começa a vida em um estado de completa dependência e quase todos passarão pela experiência da dependência, em diferentes níveis, por outras vezes ao longo da vida. Assim, a "irresponsabilidade privilegiada" (privileged irresponsibility), como nomeada por Tronto (1993, p. 174), decorre do fato de que algumas pessoas podem se autojulgar autônomas porque têm o privilégio de poder ignorar o trabalho de outras que fornecem cuidado, invisível, quando elas precisam (MOLINIER, 2017, p. 190). Logo, "compreender as dificuldades de reivindicar as necessidades do cuidado conduz a reconsiderar a noção de autonomia e, com ela o estigma associado à dependência" (MOLINIER, 2017, p. 192).

Avançando nessas reflexões, Joan Tronto (2007, p. 298) defende "transformar cuidado em um valor central nas sociedades democráticas e democratizá-lo", o que só é possível tendo em mente que todas as pessoas são vulneráveis, o que significa compreender que todas as pessoas estão no centro de uma rede complexa de relações e precisam de níveis diferentes de cuidado (TRONTO, 2007, p. 299). Além disso, exige redistribuição, pois "se os recursos utilizados para o cuidado forem desiguais, nunca seremos capazes de alcançar o objetivo democrático da igual oportunidade", e também a percepção de que o cuidado feito de forma democrática é muito melhor, rompendo com a divisão e hierarquização entre cuidador/cuidado - ou vice-versa (TRONTO, 2007, p. 301). O raciocínio da autora é encerrado da seguinte maneira:

Sendo assim, os cidadãos do mundo precisam de cuidados e podem cuidar efetivamente de outras pessoas em diferentes graus. Enquanto Aristóteles pensou ser apropriado excluir alguns para fazer com que esse tipo de reciprocidade funcionasse, nossos grandes poderes para distribuir os recursos, cuidar das pessoas e do meio ambiente cria para nós maiores responsabilidades. Temos que aceitar essas novas responsabilidades como o desafio que está diante de nós. Esta é a promessa do cuidado democrático (TRONTO, 2007, p. 302).

Assim, as abordagens éticas e políticas do cuidado colocam em cheque conceitos como responsabilidade e dependência, influenciando também na noção de cidadania,

\footnotetext{
${ }^{137}$ Noção semelhante é a de "precariedade", desenvolvida por Butler (2009, p. 40-42): “Afirmar que a vida é precária é afirmar que a possibilidade de sua manutenção depende, fundamentalmente, das condições sociais e políticas, e não somente de um impulso interno para viver (...) A precariedade tem que ser compreendida não apenas como um aspecto desta ou daquela vida, mas como uma condição generalizada cuja generalidade só pode ser negada negando-se a precariedade enquanto tal”.
} 
porque questionam os padrões que regulam a gradação com que determinados grupos sociais terão acesso a direitos ou se permanecerão à margem do sistema. A inter-relação entre essas noções e a possibilidade de reinterpretá-las parece ser a chave para desenvolver novas abordagens jurídicas que levem em conta a relação entre justiça, gênero e cuidado, o que justifica o desembocar da presente tese na busca por novos paradigmas para a cidadania, que a mim pareceu ser o pano de fundo das demandas das mulheres e movimentos com que tive contato.

\subsubsection{Novos paradigmas de cidadania}

As reflexões anteriores trouxeram a percepção de que a lógica capitalista, a qual rotula os seres humanos como indivíduos igualmente dotados de capacidade para competir no mercado, incute na sociedade a grande ilusão de que as pessoas são naturalmente independentes. Consequentemente, perspectivas analíticas que tomam indivíduos abstratamente, "como se seu cotidiano não fosse marcado pelas formas diferentes de responsabilização que estão no cerne da organização cotidiana da vida nas sociedades contemporâneas", impõem àqueles que desviam do modelo de cidadão, em especial às mulheres, "um ônus a mais, o de se posicionar como iguais - igualmente independentes, sobretudo - em condições adversas" (BIROLI, 2015, p. 101).

A respeito dessa imposição, Cristina Carrasco, Cristina Borderías e Tereza Torns (2011, p. 43) explicam que "o modelo de cidadania se construiu a partir da presença no mercado de trabalho em tempo integral dos sujeitos masculinos adultos, os únicos reconhecidos como titulares de plenos direitos". De acordo com Paperman (2017, p. 187), uma concepção de cidadania que pressupõe que as questões relativas ao cuidado pertencem apenas à esfera privada pode levar a ignorar ou minorar a importância da necessidade de cuidado, das pessoas que trabalham com ele e das pessoas que dele necessitam. Tal modelo de cidadania, fundado em valores liberais de justiça e equidade, define quem são os "bons cidadãos", calcados em critérios não apenas de pertencimento a um Estado-Nação, mas também nas fronteiras entre a vida pública e privada (PAPERMAN, 2017, p. 187).

A autora ressalta, com base nas críticas feministas, que o modelo de cidadão masculino que, por obrigação, dá sua contribuição social por meio do seu trabalho, só 
pode fazê-lo por ter uma espécie de equipe de apoio que assume, na esfera doméstica, o trabalho reprodutivo, permitindo que este cidadão apresente-se na esfera pública como pessoa dotada das capacidades da cidadania (PAPERMAN, 2017, p. 188). Mesmo que esse modelo tenha, na atualidade, colado a cidadania mais ao trabalho, ainda assim o trabalho de cuidado não é reconhecimento para esses fins (PAPERMAN, 2017, p. 188).

Susan Moller Okin (2008, p. 320), ao atestar a necessidade de relevar que categorias políticas como a cidadania "foram construídas sob a afirmação da superioridade e dominação masculinas", convida para o seguinte exercício:

É preciso perguntar: as práticas nos locais de trabalho, no mercado ou no Parlamento seriam as mesmas se elas tivessem se desenvolvido pressupondo que seus participantes teriam de acomodar-se às necessidades de dar à luz, educar um filho, e às responsabilidades da vida doméstica? As políticas e seus resultados seriam os mesmos se aqueles que nelas estão engajados fossem pessoas que também tivessem responsabilidades cotidianas significativas voltadas para os cuidados dos outros, ao invés de serem aqueles que menos probabilidade têm, em toda a sociedade, de ter essa experiência? (OKIN, 2008, p. 320)

Em consonância, Evelyn Nakano Glenn (2017, p. 19) assevera que a concepção de "cidadão ideal" repousa sobre a construção conjunta de duas figuras interdependentes: “o cidadão produtivo" e, em sua oposição, a "trabalhadora do cuidado não produtiva” e, logo, não cidadã. Ela frisa que na definição de cidadania - mais especificamente de cidadania estadunidense - as obrigações ocupam um lugar central, sendo a obrigação social de trabalhar e receber um salário a mais recorrentemente mencionada (GLENN, 2017, p. 19). A fim de aprofundar sua explicação, ela continua:

Historicamente, as obrigações civis, políticas e sociais relacionadas à cidadania foram baseadas em uma concepção normativa de cidadania. De acordo com essa concepção, o cidadão é um homem adulto, branco, colocado à frente de uma família para a qual ele apoia, e liberou restrições que poderiam impedi-lo de obter renda e agir de forma independente. Tais condições não eram simplesmente difíceis para mulheres brancas e mulheres e homens de cor; eles também assumiram que as necessidades de cuidado do chefe da família e dos familiares dependentes, como crianças, são atendidas ou mesmo dentro da família. A obrigação de obter renda para o marido e pai era o resultado da obrigação da esposa e da mãe de fornecer à família um número de serviços, incluindo o cuidado de filhos e membros da família dependentes. Dentro desse sistema, as mulheres brancas desfrutavam de vários direitos relacionados à cidadania; mas esses direitos eram direitos derivados, isto é, eles dependiam de suas relações com um chefe de família e de sua submissão à sua proteção. Da mesma forma, a obrigação de realizar o trabalho de cuidado não remunerado que lhes 
incumbia era uma obrigação derivada, dependente de sua relação com o homem encarregado de obter renda (GLENN, 2017, p. 20, tradução nossa). ${ }^{138}$

As obrigações acima descritas, de acordo com Glenn (2017, p. 22), foram incorporadas nas leis, nas políticas sociais e nas decisões judiciais, moldando-as a partir dessa moralidade social. Trazendo tais reflexões para o cenário brasileiro, pois bases e pressupostos muito similares a esses formaram o ordenamento jurídico nacional, como este trabalho demonstrou ter ocorrido no período de elaboração da CLT, verifica-se que, mesmo tendo sido revogadas as leis visivelmente atentatórias à igualdade no pós-1988, restam suas estruturas maculadas por uma lógica de servidão que perpassa gênero e raça.

Consequentemente, garantias que envolvem o cuidado, em especial a assistência social, tenderam a ser tratadas como uma prestação pública residual, excepcional, descoladas da ideia de serem direitos atrelados à cidadania (DALY; LEWIS, 2000, p 294). Nesse sentido, Bila Sorj e Adriana Fontes (2012, p. 104) afirmam que a noção de bem-estar numa sociedade deveria incluir "provisões públicas de serviços de cuidado de crianças, idosos e pessoas com necessidades especiais, promoção do emprego feminino e incentivos à distribuição equitativa das responsabilidades familiares”.

Segundo Conaghan (2005, p. 40), isso requereria uma "mudança radical" na "visão fabril" do trabalho, migrando para uma ideia de trabalho que "promove a dignidade humana e estimula a solidariedade no contexto de um reconhecimento mais amplo da interconectividade de todas as atividades laborais, produtivas e reprodutivas", independente de remunerado ou não, se realizado dentro ou fora de casa. Alinhada a esse raciocínio, Judy Fudge (2011, p. 136) fala na necessidade de se encontrar um "novo imaginário para o Direito do Trabalho".

\footnotetext{
${ }^{138}$ Excerto original: "Historiquement, les obligations civiles, politiques et sociales liées à la citoyenneté ont été fondées sur une conception normative du citoyen. Selon cette conception, le citoyen est un homme adulte, blanc, placé à la tête d'une famille aux besoins de laquelle el subvient, et libéré des contraintes qui pourraient l'empêcher de gagner un revenu et d'agir en toute indépendance. De telles conditions n'étaient pas simplement difficiles à remplir pour les femmes blanches e et les femmes et les hommes de couleur; elles supposaient aussi que les besoins de care du chef de famille et des membres dépendants de la famille comme les enfants soient pris en charge au sein même de la famille. À l'obligation de gagner un revenu qui incombait au mari et père, correspondait donc l'obligation pour l'épouse et mère de fournir à la famille un certain nombre de services, dont le soin des enfants et des membres dépendants de la famille. Au sein de ce système les femmes blanches bénéficiaient d'un certain nombre de droits liés à la citoyenneté; mais ces droits étaient des droits dérivés, autrement dit, ils dépendaient de leur relation à un chef de famille et de leur soumission à sa protection. De la même manière, l'obligation d'effectuer le travail de care non rémunéré qui leur incombait était une obligation dérivée, dépendante de leur relation à l'homme chargé de gagner un revenu".
} 
As respostas dessas autoras, entretanto, não necessariamente se encaixam à realidade e às necessidades brasileiras relativas ao tratamento do cuidado e aos padrões de cidadania, mas podem servir de incentivo para que se busquem aqui soluções. Uma via bastante difundida, considerando a ferocidade da exploração capitalista e a pauperização de grandes contingentes populacionais, são as políticas de renda mínima, como conhecidas no Brasil, que permitiriam dar condições de vida a todas as pessoas, com ou sem trabalho, diante de uma situação global que faz questionar para que tanta riqueza e desenvolvimento técnico se cada vez menos gente vive em patamares mínimos de dignidade.

Independente das respostas jurídicas e soluções de políticas públicas a serem procuradas, o que a perspectiva do cuidado reforça é que o atual sistema é insustentável e, muito além da relevância de denunciar os grupos que ele discrimina, convém frisar que ele não convém a praticamente ninguém, nem mesmo ao trabalhador que se encaixa perfeitamente nas exigências do mercado, pois seu corpo e mente são igualmente dessorados por uma lógica que exige que se viva para o trabalho alienado e que ignora a humanidade que reside na necessidade da família, do lazer e de outras relações sociais (MOLINIER, 2013, p. 198). Se o neoliberalismo nega as vulnerabilidades e estabelece seu núcleo moral sobre uma falsa autonomia e performance, a perspectiva do cuidado representa uma crítica radical ao modelo, propondo que novas formas de se vislumbrar o ser humano no trabalho a partir de outras experiências, experiências subalternas (MOLINIER, 2013, p. 198).

Ao revelar a vulnerabilidade e interdependência dos indivíduos e abrir perspectivas diversas das hegemônicas, as teorias do cuidado rompem com simplismos jurídicos que julgam que pessoas precisam de direitos - ao trabalho, à saúde, à igualdade - e ponto final. Muito além da "justiça", as pessoas precisam antes de cuidado, de relações em que elas recebam atenção (MOLINIER, 2013, p. 204). Por conseguinte, simplesmente regulamentar e atribuir valor econômico ao cuidado é confiscar sua finalidade e remetê-lo ao critério único do mercado; o horizonte deve ser, então, uma mudança mais profunda, qual seja de migrar de uma sociedade que objetiva o lucro para uma que objetiva o cuidado (JANY-CATRICE, 2012, p. 270). 


\section{CONCLUSÃO}

No percurso desta tese, cujo objetivo era revisitar, a partir da perspectiva de gênero, as bases teóricas e categorias fundamentais do Direito do Trabalho a fim de testar a hipótese de que o conceito de "trabalho" presente na legislação trabalhista é masculino e excludente, busquei costurar as teorias que versam sobre o cuidado e as problematizações de juristas feministas sobre os conceitos alicerçam a disciplina, utilizá-las para analisar o modo como o cuidado se insere no ordenamento jurídico nacional e, dando voz aos movimentos de mulheres e organizações de trabalhadoras do cuidado, devolver críticas ao Direito do Trabalho brasileiro e tatear vias para a reconstrução de alguns de seus alicerces. Tal caminho foi orientado, do ponto de vista metodológico, por uma epistemologia feminista aplicada ao campo de análise, demandando o esforço permanente de localizar meu saber e dar espaço para vozes subalternas e suas percepções.

O primeiro capítulo abordou os referenciais teóricos que serviriam de base para a realização da interpelação do Direito do Trabalho aqui proposta, fazendo um amplo movimento de apresentação do conceito de cuidado por meio de diferentes formas de abordar o conceito. A primeira delas foi a ética do cuidado, contraposta à ética da justiça, esta tomada como parâmetro pela filosofia moral e fortemente criticada por Carol Gilligan e Joan Tronto, que rompem com a concepção universalista para repensar a justiça a partir de perspectivas não dominantes, em especial relacionadas à distribuição das responsabilidades pelo cuidado. Em seguida, foi dado enfoque à problematização do cuidado como trabalho, dentro do contexto da divisão sexual do trabalho, que permite desvelar o trabalho doméstico ou de cuidado como uma tarefa de gênero, designação que determina tanto sua atribuição enquanto atividade feminina não remunerada, quanto enquanto trabalho precário, como descrito por Helena Hirata. Somou-se, então, a perspectiva da Economia Feminista, em especial de Cristina Carrasco e Silvia Federici, que revela o viés sexista das teorias econômicas majoritárias que ignoram o trabalho de cuidado empenhado para a reprodução da vida, fundamental para a manutenção do sistema econômico.

Essas três frentes desembocaram na análise da crise do cuidado, situada no contexto do capitalismo financeiro globalizado e das cadeias globais formadas para oferta de trabalhadoras migrantes de países subdesenvolvidos para países desenvolvidos, o que 
gera a sentença de que o cuidado é o "novo ouro" feita por Arlie Hochschild, pois assim como em tempos coloniais, este recurso é extraído não à força, mas por meio da coerção econômica. A crise do cuidado, porém, manifesta-se de modo diferente no Norte e no Sul global, sendo determinante para este último o fato de não terem se consolidado Estados de Bem-Estar-Social, de maneira que as relações que garantiam e garantem a reprodução social são historicamente incertas, precárias e dependentes de redes de solidariedade.

No Capítulo 2, inspirado no esforço comum das vertentes feministas vistas no capítulo anterior de ampliar e reinterpretar categorias de discursos teóricos dominantes, fiz a transposição do debate do cuidado para desafiar paradigmas do Direito do Trabalho que carregam estereótipos de gênero. Para isso, tomei como base a Teoria Feminista do Direito do Trabalho, vertente de estudo que se preocupa em demonstrar que a disciplina justrabalhista é histórica e contingente, não conceitual e universal, argumentando pela necessidade de se prestar atenção nos aspectos de gênero da organização social do trabalho, no que se inclui o trabalho doméstico e de cuidado, com o qual o ordenamento juslaboralista ainda não consegue lidar de forma satisfatória.

Busquei, a partir disso, demonstrar que as categorias fundamentais do Direito do Trabalho, supostamente neutras, na verdade possuem relevante carga sexista, procedendo um diálogo com os autores tradicionais da disciplina, a fim de situá-los e, a partir deles, avançar na crítica pretendida. A primeira categoria analisada foi a concepção jurídica de "trabalho", enquanto atividade executada no âmbito do mercado, a qual ignora que as tarefas de cuidado não remunerado sejam trabalho - ainda que necessárias, inclusive, para que haja trabalho mercantil -, o que desencadeia o tratamento do trabalho doméstico remunerado como uma modalidade "especial" de emprego, com menos direitos. Partimos depois para o modelo do trabalhador universal, que formata a legislação a partir da ideia de um sujeito de direitos que é homem, europeu, com emprego fabril em tempo integral, sindicalizado e é auxiliado pela mãe, esposa ou outra mulher a realizar as tarefas domésticas, do que deriva o tratamento legislativo das mulheres como "o outro" e das questões relativas à reprodução da vida como excepcionais.

Também foi posto em questão o tempo de trabalho, pois os moldes do trabalho subordinado em tempo integral não dão espaço para o cuidado, demonstrando a necessidade de serem pensados arranjos de jornada que amparem as responsabilidades familiares, o que é factível ao se tomar a percepção de que a própria mensuração do tempo é uma construção história. Ao final, a noção de salário foi questionada, por meio 
de uma reconstrução histórica do conceito, para demonstrar que as mulheres, por carregarem os encargos do cuidado, inserem-se no mercado já em desvantagem, o que se reflete em sua remuneração e torna ineficazes as leis de igualdade salarial. Dentro desse espectro, foi ainda possível comprovar que a utilização da perspectiva de gênero não faz da questão puramente identitária, pelo contrário, ela aporta importantes vieses na reflexão sobre os limites da disciplina jurídico trabalhista.

No Capítulo 3 busquei trilhar passos autônomos na análise do Direito do Trabalho brasileiro, o que fiz traçando o cenário de inserção cuidado no ordenamento juslaboralista nacional, não sem antes demarcar as especificidades históricas, regionais e socioeconômicas da provisão de cuidado no Brasil, em especial a predominância das trabalhadoras domésticas na oferta desses serviços. Diante dessas premissas e ancorada no diálogo com as entrevistadas, busquei as motivações e parte relevante do processo legislativo que definiu normas trabalhistas como licença-maternidade, intervalos para amamentação e direito à creche. Dediquei especial atenção para a evolução legislativa relativa aos direitos das trabalhadoras domésticas, detalhando sua exclusão da CLT, os debates constituintes e as escolhas políticas que envolveram a EC 72/2013 e a Lei Complementar 150/2015. Pude constatar o descaso com o trabalho de cuidado e, ainda mais duramente, com o emprego doméstico por parte dos doutrinadores e legisladores, notando que foi a insistência das organizações de trabalhadoras domésticas e suas parcerias políticas que permitiram o avanço da pauta.

Ademais, a tese não poderia deixar de tocar na questão da organização das trabalhadoras domésticas, que por muitos anos não foi reconhecida no Brasil, fato que revelou que também a ideia de sindicato profissional, outra categoria fundamental para o Direito do Trabalho, por estar atrelado à atividade econômica patronal, está assentada no mesmo conceito sexista e limitante de "trabalho". Por esse motivo, durante décadas as trabalhadoras domésticas mantiveram-se unidas em torno de associações civis e quase sem recursos, mas que desempenharam papel de defesa da categoria melhor que muitos sindicatos registrados. Outrossim, a regulamentação da profissão de cuidadora e de outras profissões relacionadas ao cuidado foi posta em exame - muito pleiteada pelas cuidadoras mas que sofre resistência, em especial, do setor de enfermagem -, que apesar de não representar mudanças estruturais no modo como o ordenamento jurídico lida com o cuidado, pode trazer avanços e maior valorização para quem atua na área.

Ao final do terceiro capítulo, inseri debates bastante atuais sobre mercantilização 
do cuidado, financeirização das políticas sociais e reforma trabalhista, a fim de contextualizar a tese ao processo de desmanche dos direitos sociais que se observa nos últimos anos do Brasil e que promete se concretizar por meio de reformas e outros ataques ao Direito do Trabalho e às demais garantias sociais trazidas pelas Constituição de 1988. Trazer tais considerações para a tese é permite vislumbrar o cenário em que, sem oferta de serviços públicos, a demanda por cuidado no país aumentará, apenando majoritariamente as mulheres pobres, negras e de regiões mais afastadas dos centros econômicos.

No Capítulo 4 há, enfim, é apresentada a perspectiva de movimentos de mulheres e organizações profissionais sobre como elas enxergam e demandam do ordenamento jurídico quando articulados trabalho e cuidado, para permitir retomar a teoria jurídico trabalhista e responder às limitações da disciplina para repensá-la por novas vias. Em termos concretos, isso significa que as interlocutoras revelaram haver, em sua percepção, uma segregação entre o papel das normas trabalhistas, de zelar pelas condições de trabalho mercantil, e das leis relativas aos "direitos das mulheres", nas quais enquadra-se o direito à creche, por exemplo. Isso demonstra um entendimento dos movimentos de que as pautas relativas ao cuidado precisam ser universais, logo, direitos de todas, diferente das leis trabalhistas restritas a quem possui emprego formal.

Com base nessa constatação, apresentei no item derradeiro algumas possíveis vias para reformulação do escopo da disciplina juslaboralista, que passam por novas ideias sobre justiça, pela constatação da interdependência entre os seres humanos e pela mudança da lógica que envolve a respossabilidade pelo cuidado, que não deve ser individual, mas coletiva. O capítulo desemboca na necessidade de elaboração de novos paradigmas de cidadania, que de fato considerem o cuidado como parte fundamental da estrutura social e, consequentemente, desafiem qualquer ímpeto de construção de uma sociedade sem a oferta de serviços públicos que permitam a mulheres e homens o acesso às mesmas oportunidades. Daí a potencialidade subversiva do cuidado, descrita por Helena Hirata e Pascale Molinier no início desta tese, pois revela a importância social de atividades para as quais não se dava valor, ensejando a superação desse ocultamento e a construção de algo que de fato seja uma via emancipatória.

Todo o esforço descrito vai no sentido de fazer duras críticas ao modelo tradicional do Direito do Trabalho, mas que são localizadas, tais como outras vertentes teóricas fizeram antes de mim. Logo, em nenhum momento corroboro com qualquer 
argumento em prol da desregulamentação do trabalho, sendo que, em um período de amplo ataque que os direitos sociais vêm sofrendo, sua defesa deve ser colocada em primeiro plano, como inclusive é a postura das interlocutoras desta tese. Contudo, não posso me esquivar da interpelação da disciplina aqui pretendida, que levou a concluir que as bases conceituais do Direito do Trabalho o afastam de uma plataforma igualitária, pois suas categorias básicas de hoje estão marcadas pelo gênero.

Além disso, friso que minha intenção aqui - tal como de todas as vertentes teóricas feministas percorridas na presente tese - não é de simplesmente agregar um item de estudo a mais do Direito do Trabalho, que seria o cuidado. Pelo contrário, a crítica tecida ao longo destas páginas, a tal "perspectiva de gênero" presente no título da tese, busca apontar para a necessidade de uma mudança de paradigma do campo juslaboralista. Em termos explícitos, já não basta - nem nunca bastou - que os debates de gênero sejam tratados de forma apartada do restante da teoria do Direito do Trabalho, pois dedicar-se aos temas da opressão e do cuidado vai muito além de reservar algumas linhas de um livro ou alguns minutos de um evento para falar dos "direitos das mulheres".

Esse novo olhar proposto pelo Direito do Trabalho não pode mais ser pela lente da exploração e da opressão, pelo contrário, deve partir das vozes daqueles e daquelas que dificilmente são ouvidas pelos juristas. Para isso, é preciso enfatizar que o conceito de trabalho e os demais parâmetros utilizados nas normas trabalhistas, como o padrão de trabalhador e as medidas de tempo, não são neutros, nem se aplicam uniformemente a todas as pessoas, havendo relevantes discrepâncias entre trabalho mercantil e trabalho de cuidado.

Por mais que a questão da falsa neutralidade e do viés sexista dos fundamentos disciplinares aplique-se aos mais diversos ramos da ciência - como no caso da Economia e de seu modelo de homem-econômico -, visou-se a demonstrar como ela se aplica ao Direito do Trabalho. Esse esforço envolveu a reconstrução, na medida em que os documentos e entrevistas permitiram, dos processos legislativos e debates políticos em torno de normas que abordam temas relativos ao cuidado, especialmente quanto às garantias referentes às responsabilidades familiares e a regulação de direitos para trabalhadoras domésticas. Verificou-se, com isso, a ambiguidade de um ordenamento jurídico que determina a igualdade e não discriminação, mas que se funda em noções masculinas de indivíduo e cidadão. Somando-se isso às peculiaridades do modelo 
brasileiro, o resultado encontrado é um Direito do Trabalho muito distante de sua realidade.

Por conseguinte, reunir as esferas trabalho, gênero e cuidado permitiu entender a complexidade da imbricação entre patriarcado, neoliberalismo e subdesenvolvimento, reunião que revelou as inconsistências dos marcos jurídico-trabalhistas postos na atualidade, motivo pelo qual interlocutoras da pesquisa desconectam a luta por igualdade e a luta por trabalho. Diante dessa realidade, a solução para quem pensa o Direito do Trabalho é encarar o processo de gradual de ataque à disciplina e ruína de seus alicerces e realizar um duplo exercício: defender sua existência e sua importância, sem dúvida, mas sem deixar de proceder sua crítica, ciente de que ele somente será capaz de enfrentar e minimizar os efeitos da máquina capitalista, além de explorar, oprimir e espoliar, se conseguir reformular seu escopo.

Em tal sentido, as lições da convivência com as trabalhadoras domésticas organizadas fez aumentar minha convicção na necessidade de a pesquisa no Direito abrirse para ouvir diferentes vozes, evitando fechar-se em debates sobre modelos ideais de relações de trabalho e utopias jurídicas que não correspondem às necessidades concretas de nenhum grupo oprimido. A pesquisa permitiu ver que o Direito do Trabalho não oferece respostas suficientes para essas mulheres, sendo necessário pensar em direitos da cidadania, realmente universais, que não criem margens. Daí a importância de se apontar os limites da disciplina jurídico-trabalhista, abrindo espaço para novas críticas e novas agendas de pesquisa em busca da redefiniçao de seus fundamentos.

Enfim, a pergunta que ressoa nesta tese é a seguinte: por que o Brasil cuida tão mal de quem cuida do Brasil? A teoria feminista e os estudos do cuidado ajudam a desvendar o motivo de as responsabilidades familiares serem pouco consideradas pelo Direito do Trabalho e, ainda pior, de as trabalhadoras domésticas terem permanecido por décadas como uma categoria "especial", que na prática significava que elas eram encaradas como de um estatuto inferior, merecedor de menos garantias.

Ora, se a função primordial do Direito do Trabalho é proteger trabalhadoras e trabalhadores em situação de vulnerabilidade, não havendo dúvida da situação de exploração que vivem aquelas que exercem alguma atividade do cuidado - bem como tantas outras categorias profissionais, em especial as massivamente terceirizadas -, é primordial que elas tenham a devida atenção por parte de juristas da área. Afinal, nada 
justifica a manutenção de um padrão jurídico em que possuem mais proteção social aquelas pessoas que se encaixam em um padrão de emprego que não é mais real, ainda que seja o modelo almejado, mas negado para um número crescente de brasileiras e brasileiros.

Nesse ponto, esclareço que não pretendi traçar panoramas abrangentes ou análises exaustivas referentes ao ordenamento jurídico-trabalhista nacional em relação ao cuidado, ainda que para a construção do raciocínio tenha sido necessário passar pelas normas centrais para o debate, mas sim de provocar alguns dos dogmas do Direito do Trabalho e mexer com suas bases, não para destruí-lo ou para somar-me às vozes que falam de seu suposto atraso, mas para abrir espaço para que novas perguntas, novas formulações e novas propostas ganhem espaço dentro deste campo, para que ele floresça em tempos de sombra.

Tomar a causa das trabalhadoras domésticas é, por si, um passo no sentido de chamar atenção para um dos espaços de grande potencial na luta por direitos, sendo elas integrantes da, possivelmente, mais latente das categorias profissionais e aquela que mais tem a nos ensinar. Elas seguiram e seguem organizadas, ainda que sem apoio material e com todos os sacrifícios que tiveram de enfrentar. Elas ainda sofrem com estigma, motivo pelo qual muitas das trabalhadoras do setor negam-se a aderir a uma categoria à qual querem pertencer apenas temporariamente. Elas deveriam, isso sim, ser motivo de orgulho nacional. Sem elas este país não se sustentaria; sem elas esta pesquisa nunca poderia ter chegado aos resultados aqui apresentados.

Em vista disso, enquanto não for possível repensar a organização do tempo de vida, a distribuição social e sexual de trabalho e o próprio conceito de trabalho no Direito e, mais amplamente, em toda a sociedade, não será possível atingir a igualdade. O foco no trabalho produtivo assalariado, no mercado e no consumo, somado ao escanteamento do cuidado tanto na sua provisão privada quanto no sucateamento dos serviços públicos geram uma sociedade que se torna cada dia mais insustentável. Por conseguinte, a reformulação do Direito do Trabalho não é um imperativo isolado, mas que deve ser pensado em conjunto com outras disciplinas, que carecem incorporar o cuidado.

Assim, os caminhos aqui trilhados levam, quase que irremediavelmente, a um debate de espectro mais amplo, pois verificam-se as limitações do Direito do Trabalho, que se transmutam em barreiras intransponíveis caso ele seja tratado de forma isolada. As conexões com outros ramos jurídicos, em especial o Direito da Seguridade Social e o 
Direito Econômico, tornam-se praticamente inevitáveis, já que boa parte da elaboração de respostas passa por repensar a organização social e o Estado, bem como o modo de aplicação dos recursos públicos, que deve ser solidário, voltado à pessoa não enquanto ser idealmente autônomo, pelo contrário, enquanto ser que, em maior ou menor grau, tanto demanda quanto oferta cuidado em todos os estágios de sua vida.

Concordo com Nalu Faria (2017) quando ela afirma que é preciso, em todas as dimensões, repensar o modelo como a vida humana é organizada, ampliando o conceito de economia, o conceito de trabalho, para poder abarcar as dimensões da interação entre produção e reprodução, movimento que deve ser acompanhado pelo Direito. Daí a importância desta interpelação ao Direito do Trabalho, que abre espaço para uma reflexão mais ampla sobre o modelo econômico e as políticas sociais que vem sendo implantadas nas últimas décadas neste país, única forma de visualizar os gargalos que têm sido mais problemáticos para a redução das desigualdades, no intento de atacá-los. 


\section{BIBLIOGRAFIA}

ABRAMO, Laís; VALENZUELA, Maria Elena. Tempo de trabalho remunerado e a não remunerado na América Latina. In: ABREU, Alice Rangel de Paiva; HIRATA, Helena; LOMBARDI, Maria Rosa. Gênero e trabalho no Brasil e na França: perspectivas interseccionais. São Paulo, Boitempo, 2016. p. 113-123.

ABREU, Alice Rangel de Paiva; HIRATA, Helena; LOMBARDI, Maria Rosa. Gênero e trabalho no Brasil e na França: perspectivas interseccionais. São Paulo, Boitempo, 2016.

ACCIARI, Louisa. "Foi difícil, mas sempre falo que nós somos guerreiras" - o movimento das trabalhadoras domésticas entre a marginalidade e o empoderamento. Mosaico [online], v. 7, n. 11, p. 125-147, 2016.

ACKERMAN, Bruce. Social Justice in the Liberal State. New Haven: Yale University Press, 1980.

ALVES, Alaôr Café. Determinação social e vontade jurídica. In: KASHIURA JR., Celso Naoto; AKAMINE JR., Oswaldo; MELO, Tarso de. Para a crítica do Direito: reflexões sobre teorias e práticas jurídicas. São Paulo: Outras Expressões, 2015. p. 11-44.

ANDERSON, Bridget. Just another job? The commodification of domestic labor. In: EHRENREICH, Barbara; HOCHSCHILD, Arlie Russel (ed.). Global Woman: nannies, maids, and sex workers in the New Economy. New York: Metropolitan Books, 2003. p. 104-114.

ANDERSON, Elizabeth. Feminist Epistemology and Philosophy of Science. The Stanford Encyclopedia of Philosophy [online], 2017. Disponível em: $<$ https://plato.stanford.edu/archives/spr2017/entries/feminism-epistemology/>. Acesso em: 15 abr. 2018.

ANDRADE, Everaldo Gaspar Lopes de. Princípios de Direito do Trabalho e seus fundamentos teórico-filosóficos: problematizando, refutando e deslocando o seu objeto. São Paulo: LTr, 2008.

ANDRADE, Everaldo Gaspar Lopes de. O Direito do Trabalho na Filosofia e na Teoria Social Crítica: os sentidos do trabalho subordinado na cultura e no poder das organizações. São Paulo: LTr, 2014.

ANDREUCCI, Ana Claudia Pompeu Torezan; DAMIÃO, Regina Toledo. Maternidade e previdência social: um processo de longa gestação. In: BERTOLIN, Patrícia Tuma Martins; ANDREUCCI, Ana Claudia Pompeu Torezan (org). Mulher, sociedade e direitos humanos. São Paulo: Rideel, 2010. p. 485-508.

ANDREUCCI, Ana Claudia Pompeu Torezan; TEIXEIRA, Carla Nogueira. O direito à creche no município de São Paulo: reflexões sovre os mecanismos de implementação do direito social à educação infantil. In: SMANIO, Gianpaolo Poggio; BERTOLIN, Patricia Tuma Martins; BRASIL, Patricia Cristina (org.) O Direito na fronteira das políticas públicas. São Paulo: Páginas \& Letras, 2015. p. 67-71. 
ANTUNES, Ricardo: Adeus ao trabalho? Ensaio sobre as metamorfoses e a centralidade no mundo do trabalho. São Paulo: Editora Cortez, 2008.

ANTUNES, Ricardo. Os sentidos do trabalho: ensaio sobre a afirmação e negação do trabalho. São Paulo: Boitempo Editorial, 2009.

ARAÚJO, Clara. Marxismo, feminismo e o enfoque de gênero. Crítica Marxista, São Paulo, n. 11, p. 65-70, 2000.

ARENDT, Hannah. A condição humana. 10 ed. Rio de Janeiro: Forense Universitária, 2007.

ÁVILA, Maria Betânia de Melo et. al (org.). Reflexões feministas sobre informalidade e trabalho doméstico. Recife: SOS Corpo, 2008.

ÁVILA, Maria Betânia de Melo. O tempo de trabalho das empregadas domésticas: tensões entre dominação/exploração e resistência. Recife: Editora da Universidade Federal de Pernambuco, 2009.

ÁVILA, Maria Betânia de Melo. O tempo do trabalho doméstico remunerado: entre cidadania e servidão. In: ABREU, Alice Rangel de Paiva; HIRATA, Helena; LOMBARDI, Maria Rosa. Gênero e trabalho no Brasil e na França: perspectivas interseccionais. São Paulo, Boitempo, 2016. p. 137-146.

ÁVILA, Maria Betânia de Melo. SOS Corpo - Instituto Feminista para a Democracia. Entrevista concedida a Regina Stela Corrêa Vieira e Fabiana Sanches Grecco [via Skype], 10 abr. 2017.

AZEVEDO, Débora Bithiah de; RABAT, Márcio Nuno (org.). Palavra de Mulher: oito décadas do direito de voto. Brasília: Câmara dos Deputados, 2012.

BARBOSA, Samuel. Apresentação. Novos estudos - CEBRAP, São Paulo, n. 96, p. 2731, jul. 2013.

BARROS, Alice Monteiro de. A Mulher e o Direito do Trabalho. São Paulo: LTR, 1995.

BARROS, Alice Monteiro de. Cidadania, relações de gênero e relações de trabalho. Rev. Trib. Reg. Trab. $3^{a}$ Reg., Belo Horizonte, v. 47, n. 77, p. 67-83, jan./jun. 2008.

BARROS, Verônica Altef. Organização sindical de trabalhadores domésticos: entre a realidade e a legislação. Justiça do Trabalho, Porto Alegre, v. 28, n. 326, p. 100-116, fev. 2011.

BATALHA, Cláudio. O movimento operário na Primeira República. Rio de Janeiro: Zahar, 2000.

BATISTA, Flávio Roberto. Crítica da tecnologia dos Direitos Sociais. São Paulo: Dobra Universitário, 2013.

BATISTA, Flávio Roberto. Reforma da previdência não pode ser aprovada como está. Jornal da USP, São Paulo, 10 mar. 2017. Disponível em: 
$<$ https://jornal.usp.br/atualidades/reforma-da-previdencia-nao-pode-ser-aprovada-comoesta-afirma-professor/>. Acesso em: 22 abr. 2018.

BATISTA, Marina Picazzio Perez; ALMEIDA, Maria Helena Morgani de LANCMAN, Selma. Cuidadores formais de idosos: contextualização histórica no cenário brasileiro. Revista Brasileira de Geriatria e Gerontologia, Rio de Janeiro, v. 17 n. 4, p. 879-885, 2014.

BATTHYÁNY, Karina; GENTA, Natalia; PERROTTA, Valentina. Avanzado hacia la corresponsabilidad en los cuidados: análisis de las licencias parentales en el Uruguay. Serie Asuntos de Género. Santiago: CEPAL, 2015.

BATTHYÁNY, Karina; GENTA, Natalia; SCAVINO, Sol. Análisis de género de las estrategias de cuidado infantil en Uruguay. Cadernos de Pesquisa [online], v. 47, n. 163, p. 292-319, jan./mar. 2017.

BENHABIB, Seyla. Situating the Self: Gender, Community and Postmodernity in Contemporary Ethics. Cambridge: Polity, 1992.

BENVENISTE, Émile. Problemas de linguística geral. São Paulo: Ed. Nacional, 1976.

BERCOVICI, Gilberto. A problemática da constituição dirigente: algumas considerações sobre o caso brasileiro. Revista de Informação Legislativa, Brasília, ano 36, n. 142, p. 3552, abr./jun. 1999.

BERCOVICI, Gilberto. Desigualdades regionais, Estado e Constituição. São Paulo, Max Limonad, 2003.

BERCOVICI, Gilberto. O poder constituinte do povo do Brasil: um roteiro de pesquisa sobre a crise constituinte. Lua Nova, São Paulo, v. 88, p. 305-325, 2013.

BERCOVICI, Gilberto; MASSONETTO, Luís Fernando. Os Direitos Sociais e as Constituições Democráticas Brasileiras: Breve Ensaio Histórico. In: RÚBIO, David Sanchéz; FLORES, Joaquín Herrera; CARVALHO, Salo de (org.). Direitos Humanos e Globalização: Fundamentos e Possibilidades desde a Teoria Crítica. Rio de Janeiro: Lumen Juris, 2004.

BERNSTEIN, Stéphanie. The Regulation of Paid Care Work in the Home in Quebec: From the Hearth to the Global Marketplace. In: FUDGE, Judy; OWENS, Rosemary (ed.). Precarious Work, Women, and the New Economy: The Challenge to Legal Norms. Oñati International Series in Law and Society. Onãti: Hart Publishing, 2006. p. 223-239.

BERTOLIN, Patricia Tuma Martins. Mulheres na advocacia: padrões masculinos de carreira ou teto de vidro. Rio de Janeiro: Lumen Juris, 2017.

BERTOLIN. Patricia Tuma Martins; ARAUJO, Klariene Andrielly. Efetiva inclusão no mercado de trabalho e educação nao sexista: vias para a autonomia econômica da mulher. In: SMANIO, Gianpaolo Poggio; BERTOLIN, Patricia Tuma Martins; BRASIL, Patricia Cristina (org.) O Direito na fronteira das políticas públicas. São Paulo: Páginas \& Letras, 2015. p. 49-55. 
BERTOLIN, Patrícia Tuma Martins; CARVALHO, Suzete. A segregação ocupacional da mulher: será a igualdade jurídica suficiente para superá-la? In: BERTOLIN, Patrícia Tuma Martins; ANDREUCCI, Ana Claudia Pompeu Torezan (org). Mulher, sociedade e direitos humanos. São Paulo: Rideel, 2010. p. 179-210.

BERTOLIN, Patrícia Tuma Martins. KAMADA, Fabiana Larissa. Ausentes ou invisíveis? A participação das mulheres nos sindicatos. Caderno Espaço Feminino. Uberlândia, v. 25, n. 1, p. 28-52, jan./jun. 2012.

BESSIN, Marc. Política da presença: as questões temporais e sexuadas do cuidado. In: BREU, Alice Rangel de Paiva; HIRATA, Helena; LOMBARDI, Maria Rosa. Gênero e trabalho no Brasil e na França: perspectivas interseccionais. São Paulo, Boitempo, 2016. p. $235-245$.

BIAVASCHI, Magda Barros. Os direitos das trabalhadoras domésticas e as dificuldades de implementação no Brasil: contradições e tensões sociais. São Paulo: Friedrich-EbertStiftung Brasil, 2011.

BILAC, Elisabete Dória. Trabalhos produtivos, trabalhos reprodutivos: as trajetórias femininas de trabalho e suas representações. Perspectivas, São Paulo, v. 12/13, p. 143$161,1989 / 90$.

BIROLI, Flávia. Autonomia e desigualdade de gênero: contribuições do feminismo para a crítica democrática. Vinhedo: Editora Horizonte, 2013. Não paginado [ebook].

BIROLI, Flavia. Responsabilidades, cuidado e democracia. Revista Brasileira de Ciência Política, Brasília, n.18. p. 81-117, set./dez. 2015.

BONELLI, Maria da Glória. Profissionalismo, gênero e diferença nas carreiras jurídicas. São Carlos: EDUFSCAR, 2013.

BORGEAUD GARCIANDIA, Natacha; HIRATA, Helena; MAKRIDOU, Efthymia. Note de lecture sur Gilligan, Tronto, Paperman, Laugier et Molinier. Cahiers du Genre, n. 49, p. 219-225, 2010.

BRAGA, Ruy. A política do precariado: do populismo à hegemonia lulista. São Paulo: Boitempo Editorial, 2012.

BRASIL. Projeto n. 3628, de 1961. Diário do Congresso Nacional. 24 nov. 1961. p. 9994-9998. Disponível em: <http://imagem.camara.gov.br/ Imagem/d/pdf/DCD24NOV1961.pdf\#page=10>. Acesso em 09 mai. 2018.

BRASIL. Anais da Assembleia Constituinte. Atas das Comissões. Subcomissão dos Direitos dos Trabalhadores e Servidores Públicos. 1987a. Disponível em: $<$ http://www.senado.leg.br/publicacoes/anais/asp/CT_Abertura.asp $>$. Acesso em: 12 mai. 2018.

BRASIL. Anais da Assembleia Constituinte. Atas das Comissões. Subcomissão dos Negros, Populações indígenas, pessoas deficientes e minorias. 1987b. Disponível em: $<\mathrm{http}$ ://www.senado.leg.br/publicacoes/anais/asp/CT_Abertura.asp $>$. Acesso em: 12 mai. 2018. 
BRASIL. Diário da Assembleia Nacional Constituinte, Brasília, ano 1, Suplemento ao n. 95. 16 jul. $1987 \mathrm{c}$.

BRASIL, Diário da Assembleia Nacional Constituinte, Brasília, ano 1, n. 35.27 mar. 1987d.

BRASIL. Diário da Assembleia Nacional Constituinte, Brasília, ano II, n. 290. 11 ago. 1988.

BRASIL. Secretaria de Políticas para as Mulheres. Relatório anual socioeconômico da mulher. Brasília: SPM, 2015.

BRASIL. Mulheres ganham espaço no mercado de trabalho. Brasília: Portal Brasil, 2017. Disponível em: <http://www.brasil.gov.br/economia-e-emprego/2017/03/mulheresganham-espaco-no-mercado-de-trabalho>. Acesso em: 10 set. 2017.

BRASIL. Câmara dos Deputados. Audiência Pública n. 1589/2011. 05.out.2011. Disponível em:

$<$ http://www.camara.leg.br/internet/sitaqweb/TextoHTML.asp?etapa=11\&nu

Sessao=1589/11>. Acesso em 02.ago.2016.

BRASIL. Secretaria de Políticas para as Mulheres. Relatório Anual Socioeconômico da Mulher. Brasília: SPM, 2013.

BRASIL. Congresso. Câmara dos Deputados. Centro de Documentação e Informação. Quadro histórico artigo 07, XVIII da Constituição Federal de 1988. [Mensagem institucional]. Brasília: 2014a.

BRASIL. Congresso. Câmara dos Deputados. Centro de Documentação e Informação. Quadro histórico artigo 07, XIX da Constituição Federal de 1988. [Mensagem institucional]. Brasília: 2014a.

BRASIL. Congresso. Câmara dos Deputados. Centro de Documentação e Informação. Quadro histórico artigo 07, XXV da Constituição Federal de 1988. [Mensagem institucional]. Brasília: 2014c.

BRASIL. Governo Federal. Governo recebe pauta da Marcha das Margaridas. 06.jul.2015a. Disponível em: <http://www.brasil.gov.br/governo/2015/07/governorecebe-pauta-da- marcha-das-margaridas $>$. Acesso em 02.ago.2016.

BRASIL. Senado Federal. Participantes de audiência na CDH condenam terceirização na área da saúde. 14.jul.2015b. Disponível em: <http://www12.senado.leg.br/noticias/ materias/2015/07/14/participantes-de-audiencia-na-cdh-condenam-terceirizacao-na-areada- saude>. Acesso em 02.ago.2016.

BRASIL. Senado Federal. $2 a$ Sessão Legislativa Ordinária da $55 a$ Legislatura. 2.mai.2016. Disponível em: $<$ http://www12.senado.leg.br/noticias/arquivos/2016/04/29/veja-a-pauta- completa-dacdh $>$. Acesso em 02.ago.2016. 
BRASIL. Ministério da Saúde. Aleitamento materno. s./d. Disponível em: $<$ http://portalms.saude.gov.br/saude-para-voce/saude-da-crianca/aleitamento-materno $>$. Acesso em 12 mai. 2018.

BRESSIANI, Nathalie. Redistribuição e reconhecimento: Nancy Fraser entre Jürgen Habermas e Axel Honneth. Caderno CRH, Salvador, v. 24, n. 62, p. 331-352, maio/ago.2011.

BRITES, Jurema Gorski. Trabalho doméstico: questões, leituras e políticas. Cadernos de Pesquisa, São Paulo, v. 43, n. 149, p. 422-451, ago.2013.

BUTLER, Judith. Frames of War: When Is Life Grievable. New York: Verso, 2009.

CAETANO, Solange Aparecida. Federação Nacional dos Enfermeiros. Entrevista concedida a Regina Stela Corrêa Vieira [Whatsapp], 27 jan. 2017

CAMARANO, Ana Amélia (org.). Cuidados de longa duração para a população idosa: um novo risco social a ser assumido? Rio de Janeiro: IPEA, 2010.

CANADA. Ontario. Employment Standards Act, 2000. Disponível em: $<$ https://www.ontario.ca/laws/statute/00e41\#BK114>. Acesso em: 12 mai. 2018.

CARRASCO, Cristina. El trabajo domestico. Un análisis económico. Madrid: Ministerio de Trabajo y Seguridad Social, 1991.

CARRASCO, Cristina. La economía del cuidado: planteamiento actual y desafíos pendientes. Revista de Economía Critica, v. 11, p. 205-225, 2011.

CARRASCO, Cristina; BORDERÍAS, Cristina; TORNS, Teresa (ed.). El trabajo de cuidados: historia, teoría y políticas. Madrid: Catarata, 2011.

CARRASCO, Cristina. El cuidado como eje vertebrador de una nueva economía. Cuadernos de Relaciones Laborales [online], v. 31, n. 1, p. 39-56, 2013.

CARRASCO, Cristina. Introducción. In: CARRASCO, Cristina (ed.). Con voz propia: la economía feminista como apuesta teórica y política. Madrid: La oveja roja, 2014. p. 1524.

CARRASCO, Cristina. La economía feminista: ruptura teórica y propuesta política. In: CARRASCO, Cristina (ed.). Con voz propia: la economía feminista como apuesta teórica y política. Madrid: La oveja roja, 2014. p. 25-47.

CARRASCO, Cristina. Universitat de Barcelona. Entrevista concedida a Regina Stela Corrêa Vieira e Fabiana Sanches Grecco, Barcelona, 05 jun. 2017.

CASTEL, Robert. Les métamorphoses de la question sociale: une chronique du salariat. Paris: Fayard, 1995.

CASTEL, Robert. La montée des incertitudes: travail, protections, statut de l'individu. Paris: Éditions du Seuil, 2009. 
CESARINO JÚNIOR, Antonio Ferreira. Evolução do Direito Social Brasileiro. Revista da Faculdade de Direito da Universidade de São Paulo, São Paulo, v. 47, p. 185-205, 1952.

CESARINO JÚNIOR, Antonio Ferreira. Direito social brasileiro. v. 1. 6. ed. Sao Paulo : Saraiva, 1970a.

CESARINO JÚNIOR, Antonio Ferreira. Direito social brasileiro. v. 2. 6. ed. Sao Paulo : Saraiva, 1970 b.

CHARLESWORTH, Hillary. What are 'Women's international human rights'? In: COOK, Rebecca .J. (ed.) Human, Rights of Women, National and International Perspectives. Philadelphia: University of Pennsylvania Press, 1994. p. 58-84.

CHENAL, Odile; KERGOAT, Danièle. Production et reproduction: les jeunes travailleuses, le salariat et la famille. In: KERGOAT, Danièle. Se battre, disent-elles... Paris: La Dispute, 2012.

COHN, Amélia. Desigualdade, desenvolvimento social e políticas sociais no Brasil. Cadernos Cedec, São Paulo, n. 57, p. 6-45, 1996.

COHN, Amélia. A questão social no Brasil: construção da cidadania. In: MOTA, Carlos Guilherme (org.). Viagem incompleta: a experiência brasileira (1500-2000): a grande transação. São Paulo: Editora SENAC, 2000. p. 384-403.

COLLINS, Patricia Hill. Black feminist thought: knowledge, consciousness, and the politics of empowerment. 2. ed. New York: Routledge, 2002.

CONAGHAN, Joanne. Feminism and labour law: contesting the terrain. In: MORRIS, Anne; O'DONNELL, Therese. Feminist Perspectives on Employment Law. London: Cavendish Publishing Limited, 1999. p. 13-41.

CONAGHAN, Joanne. Work, family, and the discipline of labour law. In: CONAGHAN, Joanne; RITTICH, Kerry (ed.). Labour law, work, and family: critical and comparative perspectives. Oxford: Oxford University Press, 2005. p. 19-42.

CONAGHAN, Joanne. Time to Dream? Flexibility, Families, and the Regulation of Working Time. In: FUDGE, Judy; OWENS, Rosemary (ed.). Precarious Work, Women, and the New Economy: The Challenge to Legal Norms. Oñati International Series in Law and Society. Onãti: Hart Publishing, 2006. p. 101-129.

CONAGHAN, Joanne. Gender and the idea of labour law. Feminists@law [online], v. 4, n. 1, p. 1-20, 2014.

CONAGHAN, Joanne; RITTICH, Kerry. Introduction: Interrogating the work/family divide. In: CONAGHAN, Joanne; RITTICH, Kerry (ed.). Labour law, work, and family: critical and comparative perspectives. Oxford: Oxford University Press, 2005 p. 1-16

CNDM. Carta das Mulheres à Assembleia Constituinte. Brasília: Conselho Nacional dos Direito da Mulher, Ministério da Justiça, 1987. Disponível em: $<$ http://www2.camara.leg.br/atividade-legislativa/legislacao/Constituicoes_Brasileiras/ constituicao-cidada/constituintes/a-constituinte-e-as-mulheres/Constituinte\%201987- 
1988-Carta\%20das\%20Mulheres\%20aos\%20Constituintes.pdf>. Acesso em: 12 mai. 2018 .

CONTAG. Caderno de textos da Marcha das Margaridas 2015. Disponível em: $<$ https://www.contag.org.br/imagens/f2308caderno-de-textos-para-estudos-e-debates--marcha-das-margaridas-2015_versaofinal_site.pdf>. Acesso em: 02.jul.2016.

CORACINI, Maria José R. Faria. Um fazer persuasivo: o discurso subjetivo da ciência. São Paul o: Educ; Campinas: Pontes, 1991.

COSTA, Albertina de Oliveira et. al. (org.). Mercado de trabalho e gênero. Rio de Janeiro: Editora FGV, 2008.

COSTA, Albertina de Oliveira; SORJ, Bila; BRUSCHINI, Cristina; HIRATA, Helena (org.). Mercado de trabalho e gênero. Rio de Janeiro: Editora FGV, 2008.

COSTA, Carlos. A academia é um espaço para promover a mudança: entrevista com Tatau Godinho. Revista Comunicare, São Paulo, v. 14, n. 1, p. 12-16, 2014.

CRAIN, Marion. Images of power in labor law: a feminist deconstruction. Boston College Law Review [online], v. XXXIII, n. 3, p. 481-537, mai. 1992.

CRESSON, Geneviève. Le travail domestique de santé : analyse sociologique. Paris : Éditions L'Harmattan, 1995.

COHN, Amélia. Um assassinato cruel. Le Monde Diplomatique [online], 11 abr. 2017. Disponível em: <https://diplomatique.org.br/um-assassinato-cruel/>. Acesso em: 22 abr. 2018 .

CONAGHAN, Joanne. Work, family, and the discipline of labour law. In: CONHAGHAN, Joanne; RITTICH, Kerry (ed.). Labour law, work, and family: critical and comparative perspectives. Oxford: Oxford University Press, 2005. p. 19-42.

CUEVA, Mario de la. El nuevo derecho mexicano del trabajo: historia, principios fundamentales, derecho individual y trabajos especiales. 4. ed. México DF: Editorial Porrua, 1977.

DALTON, Clare. Where We Stand: Observations on the Situation of Feminist Legal Thought. Berkeley Women's Law Journal [online], v. 3, n. 1, p. 1-13, 1987.

DALY, Mary; LEWIS, Jane. The concept of social care and the analysis of the contemporary welfare states. British Journal of Sociology, v. 51, n. 2, p. 281-298, jun. 2000 .

DAMAMME, Aurélie; HIRATA, Helena; MOLINIER, Pascale (coord.). Le travail entre public, privé et intime: comparaisons et enjeux internationaux du care. Paris: Éditions L'Harmattan, 2017.

DEBERT, Guita Grin. Imigrantes. Estado e família: o cuidado do idoso e suas vicissitudes. In: GUIMARÃES, Nadya Araujo; HIRATA, Helena (org.). Cuidado e cuidadoras: as várias faces do trabalho do care. São Paulo: Atlas, 2012. p. 216-233. 
DEBERT, Guita Grin. Políticas públicas diante do envelhecimento no Brasil. In: ABREU, Alice Rangel de Paiva; HIRATA, Helena; LOMBARDI, Maria Rosa. Gênero e trabalho no Brasil e na França: perspectivas interseccionais. São Paulo, Boitempo, 2016. p. $247-256$

DEBERT, Guita Grin; PULHEZ; Mariana Marques. Desafios do cuidado: Apresentação. In: DEBERT, Guita Grin; PULHEZ; Mariana Marques (org.). Desafios do cuidado: gênero, velhice e deficiência. Campinas: Unicamp/IFCH, 2017. p. 5-27.

DELGADO, Mauricio Godinho. Curso de Direito do Trabalho. 16. ed. São Paulo, LTr, 2017.

DELGADO, Mauricio Godinho. Direito Coletivo do trabalho. 7. ed. São Paulo: LTr, $2017 b$.

DELPHY, Christine. Familiar Exploitation: A New Analysis of Marriage in Contemporary Western Societies. Cambridge: Polity Press, 1992

DELPHY, Christine. Féminisme et marxisme. In: MARUANI, Margaret (dir.). Femmes, genre et sociétés: l'état des savoirs. Paris: La Decouverte, 2005. p. 32-37.

DELPHY, Christine. O inimigo principal: a economia política do patriarcado. Revista Brasileira de Ciência Política, Brasília, n. 17, p. 99-119, ago. 2015.

DIEESE. A saúde do trabalhador no processo de negociação coletiva no Brasil. Estudos e Pesquisas. São Paulo: DIEESE, 2015.

DIEESE. PEC 287: a minimização da previdência pública. Nota técnica n. 168. São Paulo: DIEESE, 2017.

DOMÉSTICA. Direção: Gabriel Mascaro. Produção: Rachel Ellis. Recife: Desvia, 2012.

DWORKIN, Ronald. Levando os direitos a sério. 3. ed. São Paulo: Martins Fontes, 2010.

EHRENREICH, Barbara; HOCHSCHILD, Arlie Russel (ed.). Global Woman: nannies, maids, and sex workers in the New Economy. New York: Metropolitan Books, 2003.

ENGELS, Friedrich. A Origem da família, da propriedade privada e do Estado. 9. ed. Rio de Janeiro: Civilização Brasileira, 1984.

EPSTEIN, Lee; KING, Gary. Pesquisa empírica em direito: as regras de inferência. São Paulo: Direito GV, 2013.

FARIA, Nalu. Sempreviva Organização Feminista. Entrevista concedida a Regina Stela Corrêa Vieira, São Paulo, 27 jan. 2017.

FAVRET-SAADA, Jeanne. Ser afetado. Cadernos de Campo, n. 13, p. 155-161, 2005.

FCC. Banco de dados sobre o trabalho das mulheres. São Paulo: Fundação Carlos Chagas, 2010.2 Disponível em: $<$ http://www.fcc.org.br/bdmulheres/serie2.php?area=series>. Acesso em 4.jul.2016. 
FEDERICI, Silvia. Revolution at Point Zero: Housework, Reproduction, and Feminist Struggle. Oakland: PM Press, 2012. Não paginado (e-book).

FEDERICI, Silvia. Calibã e a bruxa: mulheres, corpo e acumulação primitiva. São Paulo: Editora Elefante, 2017a.

FEDERICI, Silvia. Notas sobre gênero em O Capital de Marx. Cadernos Cemarx [online], n. 10, p. 83-111, 2017 b.

FELICIANO, Guilherme Guimarães. Dos princípios do Direito do Trabalho no mundo contemporâneo. p. 115-138. In: SIQUEIRA, Germano et. al. (org.). Direito do Trabalho: releituras, resistência. São Paulo: LTr, 2017.

FENATRAD. Assembleia com lideranças sindicais da categoria ratifica Fenatrad. 16 ago. 2017. Disponível em: <http://www.fenatrad.org.br/site/?p=2311>. Acesso em: 02 fev. 2018 .

FERNANDES, Fabiana Silva; GIMENES, Nelson; DOMINGUES, Juliana dos Reis. Mulheres e filhos menores de três anos: condições de vida. Cadernos de Pesquisa, São Paulo, v. 47, n. 163, p. 320-341, jan./mar. 2017.

FERNANDEZ, Florestan. A revolução burguesa no Brasil: ensaio de interpretação sociológica. 2. ed. Rio de Janeiro: Zahar Editores, 1976.

FINEMAN, Martha Albertson. Legal stories, change, and incentives - reinforcing the law of the father. New York School Law Review [online], v. 37, p. 227-249, 1992.

FINEMAN, Martha Albertson. The autonomy myth: a theory of dependency. 2. ed. New York: The New Press, 2005.

FINEMAN, Martha Albertson; DOUGHERTY, Terence (ed.). Feminism confronts homo economicus. New York: Cornell University Press, 2005.

FISHER, Berenice; TRONTO, Joan. Toward a Feminist Theory of Caring. In: ABEL, Emily K.; NELSON, Margaret K. (ed.). Circles of Care: Work and Identity in Women's Lives. Albany: SUNY Press, 1990. p. 35-62.

FNE. Enfermagem 30 horas. 10.nov.2014. Disponível em: $<$ http://www.portalfne.com.br/video/enfermagem-30-horas>. Acesso em 10.jul.2016.

FOHLEN, Claude; BÉDARIDA, François. Historia general del trabajo: la era de las revoluciones. Barcelona: Ediciones Grijalbo, 1965.

FOLBRE, Nancy. Who pays for the kids? Gender and the structures of constraints. 2. ed. New York: Routledge, 2003.

FOLBRE, Nancy. A theory of the misallocation of time. In: FOLBRE, Nancy; BITTMAN, Michael (ed.). Family time: the social organization of care. London: Routledge, 2004. p. 18-35.

FOLBRE, Nancy. Measuring Care: Gender, Empowerment, and the Care Economy. Journal of Human Development, v. 7, n. 2, p. 183-199, 2006. 
FOLBRE, Nancy. Greed, lust \& gender: a history of economic ideas. Oxford: Oxford University Press, 2009.

FOLBRE, Nancy. The Care Economy in Africa: Subsistence Production and Unpaid Care. Journal of African Economies [online], v. 23, AERC Supplement 1, p. i128-i156, 2013.

FOLBRE, Nancy. Who cares? A feminist critique of the care economy. New York: Rosa Luxemburg Stiftung, 2014.

FOLBRE, Nancy; NELSON, Julie A. For love or money - or both? The Journal of Economic Perspectives [online], v. 14, v. 4, p. 123-140, 2000.

FONSECA, Maria Hemília. Direito do Trabalho: um direito fundamental no ordenamento jurídico brasileiro. Tese (Doutorado). Faculdade de Direito da Pontifícia Universidade de São Paulo. Orientador Cássio de Mesquisa Barros Júnior. São Paulo, 2006.

FONSECA, Maria Hemília; CINTRÃO, Conrado Ferri. Trabalho doméstico como forma análoga de trabalho escravo. In: BORGES, Paulo César Corrêa (org.). Formas contemporâneas de trabalho escravo. São Paulo: NETPDH; Cultura Acadêmica Editora, 2015. p. 93-103.

FRACCARO, Glaucia Cristina Candian. Os direitos das mulheres: organização sindical e legislação trabalhista no entreguerras brasileiro (1917-1937). 2016. Tese (Doutorado em História) - Universidade Estadual de Campinas, Campinas.

FRACCARO, Glaucia. Secretaria de Políticas para as Mulheres. Entrevista concedida a Regina Stela Corrêa Vieira, Campinas, 04 out. 2017.

FRACCARO, Glaucia Cristina Candian. Mulheres, sindicato e organização política nas greves de 1917 em São Paulo. Revista Brasileira de História, São Paulo, v. 27, n. 76, p. 73-90, set./dez. $2017 b$.

FRASER, Nancy. What's Critical about Critical Theory? The Case of Habermas and Gender. In: FRASER, Nancy. Unrully Practices: Power, Discourse, and Gender in Contemporary Society. Minneapolis: University of Minnesota Press, 1989.

FREITAS JR., Antonio Rodrigues de. O trabalho à procura de um direito: crise econômica, conflitos de classe e proteção social na Modernidade. Estudos Avançados [online], v. 28, n. 81, p. 69-93, 2014.

FONSECA, Maria Hemília. Direito ao Trabalho: um direito fundamental no ordenamento jurídico brasileiro. São Paulo. 373 f. Tese [doutorado]. Faculdade de Direito da Pontifícia Universidade Católica, 2006.

FOUCAULT, Michel. História da sexualidade I: A vontade de saber. Rio de Janeiro: Edições Graal, 1988.

FRASER, Nancy. After the Family wage: gender equity and the Welfare State. Political Theory [online], v. 22, n. 4, p. 591-618, nov. 1994 
FRASER, Nancy. Da redistribuição ao reconhecimento? Dilemas da justiça na era póssocialista. In: SOUZA, Jessé. (org.). Democracia hoje: Novos desafios para a teoria democrática contemporânea. Brasília: UNB, 2001. p. 245-282.

FRASER, Nancy. Políticas feministas na era do reconhecimento: uma abordagem bidimensional da justiça de gênero. In: BRUSCHINI, Cristina; UNBEHAUN, Sandra (org.). Gênero, democracia e sociedade brasileira. São Paulo: FCC, 2002. pp. 59-78.

FRASER, Nancy. Mercantilização, proteção social e emancipação: as ambivalências do feminismo na crise do capitalismo. Revista Direito GV, v. 7, n. 2, p. 617-634, 2011.

FRASER, Nancy. Fortunes of feminism: from State-Managed Capitalism to Neoliberal Crisis. Verso: London/New York, 2013.

FRASER, Nancy. Contradictions of capital and care. New Left Review [online], v. 100, p. 99-117, jul./ago. 2016.

FRASER, Nancy; HONNETH, Axel. Redistribution or recognition? A PoliticalPhilosophical Exchange. London/New York: Verso, 2003.

FREDMAN, Sandra. Precarious Norms for Precarious Workers. In: FUDGE, Judy; OWENS, Rosemary (ed.). Precarious Work, Women, and the New Economy: The Challenge to Legal Norms. Oñati International Series in Law and Society. Onãti: Hart Publishing, 2006. p. 177-199.

FUDGE, Judy. Rungs on the Labour Law Ladder: Using Gender to Challenge Hierarchy. Saskatchewan Law Review, v. 60, n. 2, p. 237-264, 1996.

FUDGE, Judy. A new gender contract ? Work/Life balance and working-time flexibility. In: CONAGHAN, Joanne ; KERRY, Rittich (ed.). Labour law, work and family: critical and comparative perspectives. Oxford : Oxford University Press, 2005. p. 261-287.

FUDGE, Judy. Labour as a 'fictive commodity' : radically reconceptualizing Labour Law. In : DAVIDOV, Guy ; LANGILLE, Brian. The idea of Labour Law. Oxford : Oxford Press, 2011. p. 120-136.

FUDGE, Judy. Feminist Reflections on the Scope of Labour Law: Domestic Work, Social Reproduction, and Jurisdiction. Feminist Legal Studies [online], v. 22, n. 1, p. 123, 2014.

FUDGE, Judy. A New Vocabulary and Imaginary for Labour Law: Taking Legal Constitution, Gender, and Social Reproduction Seriously. In: BRODIE, Douglas; BUSBY, Nicole; ZAHN, Rebecca (ed.). The Future Regulation of Work: New Concepts, New Paradigms., London: Palgrave Macmillan, 2016. p. 7-26.

FUDGE, Judy. Kent Law School. Entrevista concedida a Regina Stela Corrêa Vieira, Canterbury, 12 mai. 2017.

FUDGE, Judy; MCCRYSTAL, Shae; SANKARAN, Kamala (ed.). Challenging the legal boundaries of work regulation. International Series in Law and Society. Onãti: Hart Publishing, 2012. 
FUDGE, Judy; OWENS, Rosemary (ed.). Precarious Work, Women, and the New Economy: The Challenge to Legal Norms. Oñati International Series in Law and Society. Onãti: Hart Publishing, 2006.

FUDGE, Judy; GRABHAM, Emily. Introduction: Gendering Labour Law. feminists@law[online], v. 4, n. 1, p. 1-4, 2014.

GALVÃO, Andréia et. al. Dossiê Reforma Trabalhista (em construção). Campinas: CESIT, jun. 2017.

GEORGES, Isabel. O ‘cuidado' como ‘quase-conceito': por que está pegando? Notas sobre a resiliência de uma categoria emergente. In: DEBERT, Guita Grin; PULHEZ; Mariana Marques (org.). Desafios do cuidado: gênero, velhice e deficiência. Campinas: Unicamp/IFCH, 2017. p. 123-151.

GILLIGAN, Carol. In a different voice: psychological theory and women's development. 38. ed. Cambridge: Harvard Press University, 2003.

GIORGE, Lídia Nadir. Associação dos Cuidadores de Idosos da Região Metropolitana de São Paulo. Entrevista concedida a Regina Stela Corrêa Vieira, São Paulo, 26 jan. 2017.

GLENN, Evelyn Nakano. Forced to care: coercion and caregiving in America. Harvard: Harvard University Press, 2010.

GLENN, Evelyn Nakano. La race, le genre et l'obligation de prendre soin (care). In: DAMAMME, Aurélie; HIRATA, Helena; MOLINIER, Pascale (coord.). Le travail entre public, privé et intime: comparaisons et enjeux internationaux du care. Paris: Éditions L'Harmattan, 2017.

GODINHO, Tatau. Secretaria de Políticas para as Mulheres da Presidência da República. Entrevista concedida a Regina Stela Corrêa Vieira, São Paulo, 26 abr. 2018.

GOLDENBERG, Mirian. A arte de pesquisar: como fazer pesquisa qualitativa em Ciências Sociais. 8. ed. Rio de Janeiro: Editora Record, 2004.

GOMES, Angela de Castro. A invenção do trabalhismo. 3. ed. Rio de Janeiro: Editora FGV, 2005.

GRATAO, Aline Cristina Martins; et. al. Sobrecarga e desconforto emocional em cuidadores de idosos. Texto e Contexto - Enfermagem, Florianópolis, v.21. n.2, abr./jun. 2012.

GROSSI, Miriam Pilar; SARDENBERG, Cecilia Maria Bacellar. Balanço sobre a Lei Maria da Penha. Estudos Feministas, Florianópolis, v. 23, n. 2, p.497-500, mai.-ago. 2015.

GUIMARÃES, Nadya Araujo; HIRATA, Helena; SUGITA, Kurumi. Cuidado e cuidadoras: o trabalho de care no Brasil, França e Japão. Sociologia \& Antropologia, Rio de Janeiro, v. 1, n. 1, p. 151-180, jun. 2011.

GUIMARÃES, Nadya Araujo; HIRATA, Helena Sumiko; SUGITA, Kurumi. Cuidado e cuidadoras: o trabalho do care no Brasil, França e Japão. In: GUIMARÃES, Nadya 
Araujo; HIRATA, Helena (org.). Cuidado e cuidadoras: as várias faces do trabalho do care. São Paulo: Atlas, 2012.

GUIMARÃES, Nadya Araujo; BRITO, Murillo Marschener Alves de. Mercantilização no feminino: a visibilidade do trabalho das mulheres no Brasil. In: ABREU, Alice Rangel de Paiva; HIRATA, Helena; LOMBARDI, Maria Rosa. Gênero e trabalho no Brasil e na França: perspectivas interseccionais. São Paulo, Boitempo, 2016. p. 71-82.

GUIMARÃES, Pilar Carvalho. De trabalhadoras a militantes: a luta das mulheres do sindicato de trabalhadoras domésticas de Campinas-SP. 2016. Dissertação (Mestrado em Educação) - Faculdade de Educação, Universidade Estadual de Campinas, Campinas.

HARAWAY, Donna. Saberes localizados: a questão da ciência para o feminismo e o privilégio da perspectiva parcial. Cadernos Pagu, Campinas, v. 5, p. 7-41, 1995.

HARDING, Sandra. Introduction: standpoint theory as a site of political, philosophic, and scientific debate. In: HARDING, Sandra (ed.). The feminist standpoint theory reader: intellectual and political controversies. New York: Routledge, 2004. p. 1-15.

HARVEY, David. Para entender O Capital: livro I. São Paulo: Boitempo, 2013.

HIMMELWEIT, Susan. The discovery of "unpaid work": the social consequences of the expansion of "work". Feminist Economics [online], n. 1, v. 2, p. 1-19, 1995.

HIRATA, Helena. Divisão - Relações sociais de sexo e do trabalho: contribuição à discussão sobre o conceito de trabalho. Em Aberto, Brasília, MEC/Inpe, v. 1, n. 65, p. 3949, jan./mar.1995. p. 40

HIRATA, Helena. Globalização e divisão sexual do trabalho. Cadernos Pagu [online], v. 17-18, p. 139-156, 2001/2002.

HIRATA, Helena. A precarização e a divisão internacional e sexual do trabalho. Sociologias, Porto Alegre, v. 11, n. 21, p. 24-41, jan./jun. 2009.

HIRATA, Helena. O trabalho do cuidado (care) em perspectiva comparada: França, Japão e Brasil. Redistribuição, reconhecimento e representação: Diálogos sobre igualdade de gênero. ABREU, Maria Aparecida (org). p. 83-107. Brasília: IPEA, 2011a.

HIRATA, Helena. Questions sur la qualité des emplois du care: France, Brésil, Japon. Travail, genre et sociétés, n. 26, p. 199-203, nov. 2011 b.

HIRATA, Helena. Genre, travail et care: l'état des travaux en France. Revista Latinoamericana de Estudos do Trabalho [online], v. 16, n. 26, p. 37-56, $2011 \mathrm{c}$.

HIRATA, Helena. Gênero, classe e raça Interseccionalidade e consubstancialidade das relações sociais. Tempo soc., São Paulo, v. 26, n. 1, p. 61-73, jun. 2014a.

HIRATA, Helena. O trabalho de cuidado. In: OLIVEIRA, Juliana Andrade; MATSUO, Myriam (org.). O trabalho emocional e o trabalho de cuidado. São Paulo: Fundacentro, 2014b. p. 27-35. 
HIRATA, Helena; DEBERT, Guita Grin. Apresentação. Cadernos Pagu [online], v. 46, p. 7-15, jan./abr.2016.

HIRATA, Helena; GUIMARÃES, Nadya Araujo (org.). Cuidado e cuidadoras: as várias faces do trabalho do care. São Paulo: Atlas, 2012.

HIRATA, Helena; MOLINIER, Pascale. Les ambiguïtés du care. Travailler, Paris, n. 28, p. 9-13, 2012.

HIRATA, Helena; MAKRIDOU, Efthymia; MATSUO, Myrian. Trajectoires professionnelles et rapports sociaux: le travail du care dans une perspective comparative. In: DAMAMME, Aurélie; HIRATA, Helena; MOLINIER, Pascale (coord.). Le travail entre public, privé et intime: comparaisons et enjeux internationaux du care. Paris: Éditions L'Harmattan, 2017. p. 33-53.

HIRATA, Helena. KERGOAT, Danièle. Novas configurações da divisão sexual do trabalho. Cadernos de Pesquisa [online], v. 37, n. 132, p. 595-609, set./dez. 2007.

HIRATA, Helena; KERGOAT, Danièle. Paradigmas sociológicos e categoria de gênero. Que renovação aporta a epistemologia do trabalho? Novos cadernos NAEA [online], v. 11, n. 1, p. 39-50, jun. 2008a.

HIRATA, Helena. KERGOAT, Danièle. Divisão sexual do trabalho profissional e doméstico: Brasil, França, Japão. In: COSTA, Albertina de Oliveira. SORJ, Bila. BRUSCHINI, Cristina. HIRATA, Helena (orgs). Mercado de Trabalho e Gênero: comparações internacionais. Rio de Janeiro: FGV, 2008b. p. 263- 278.

HIRATA, Helena; KERGOAT, Danièle. Les paradigmes sociologiques à l'épreuve des catégories de sexe. Papeles del CEIC, n. 17, p. 1-15, 2005. Disponível em: <www.redalyc.org/html/765/76529008001>. Acesso em : 20 set. 2017.

HIRATA, Helena; ZARIFIAN, Philippe. Trabalho (conceito de). In: HIRATA, Helena et al. (org.). Dicionário Crítico do Feminismo. São Paulo: Editora Unesp, 2009. p. 251251-256.

HOBSBAWN, Eric J. Mundos do Trabalho. São Paulo: Paz e Terra, 2008.

HOCHSCHILD, Arlie Russell. Emotion work, feeling rules, and social structure. American Journal of Sociology [online], v. 85, n. 3, nov. 1979, p. 551-575.

HOCHSCHILD, Arlie Russell. Global Care Chains and Emotional Surplus Value. In: HUTTON, William; GIDDENS, Anthony (ed.). On the Edge: Living with Global Capitalism. London: Jonathon Cape, 2000.

HOCHSCHILD, Arlie Russell. The Time Bind: when work becomes home and home becomes work. 2. ed. New York: Holt Paperback, 2001.

HOCHSCHILD, Arlie Russell. Love and Gold. In: EHRENREICH, Barbara; HOCHSCHILD, Arlie Russel (ed.). Global Woman: nannies, maids, and sex workers in the New Economy. New York: Metropolitan Books, 2003. p. 15-30. 
HOCHSCHILD, Arlie Russell. Strangers in their own land: anger and mourning on the American Right. New York: The New Press, 2016.

HOCHSCHILD, Arlie R.; EHRENREICH, Barbara. Global Woman: nannies, maids and sex workers in the New Economy. New York: Henry Holt and Company, 2004.

HORREL, Sara; HUMPHRIES, Jane. Women's labour force participation and the transition to the male-breadwinner family, 1790-1865. Economic History Review, v. 63, n. 1, p. 89-117, 1995.

HUNT, E. K.; LAUTZENHEISER, Mark. History of economic thought: a critical perspective. 3. ed. New York: M. E. Shape, 2011.

IANNI, Octavio. O mundo do trabalho. São Paulo em Perspectiva [online], v. 8, n. 1, p. 2-12, jan./mar.1994.

IBGE. Estatísticas de gênero: uma análise dos resultados do censo demográfico 2010. Rio de Janeiro: IBGE, 2014.

IBGE. Mudança demográfica no Brasil no início do século XXI: subsídios para as projeções da população. Rio de Janeiro: Instituto Brasileiro de Geografia e Estatística, 2015.

IBGE. Síntese de indicadores sociais: uma análise das condições de vida da população brasileira 2016. Rio de Janeiro: Instituto Brasileiro de Geografia e Estatística, 2016.

IBGE. IBGE divulga as estimativas populacionais dos municípios para 2017. Agência IBGE Notícias, 31 ago. 2017. Disponível em: <https://agenciadenoticias.ibge.gov.br/ agencia-noticias/2013-agencia-de-noticias/releases/16131-ibge-divulga-as-estimativaspopulacionais-dos-municipios-para-2017.html>. Acesso em: 17 jan. 2018.

IBGE. Pesquisa Nacional por Amostra de Domicílios Contínua Segundo trimestre de 2017. Rio de Janeiro: IBGE, 2017. Disponível em: $<\mathrm{ftp}$ ://ftp.ibge.gov.br/Trabalho_e_Rendimento/Pesquisa_Nacional_por_Amostra_de_Do micilios_continua/Trimestral/Fasciculos_Indicadores_IBGE/pnadc_201702_trimestre_ca derno.pdf $>$. Acesso em 10 set. 2017. p. $\overline{21}$.

IBGE. Pnad Contínua: taxa de desocupação foi de $12,6 \%$ no trimestre encerrado em fevereiro. Agência IBGE Notícias, 29 mar. 2018. Disponível em: $<$ https://agenciadenoticias.ibge.gov.br/agencia-noticias/2013-agencia-denoticias/releases/20675-pnad-continua-taxa-de-desocupacao-foi-de-12-6-no-trimestreencerrado-em-fevereiro.html>. Acesso em: 13 mai. 2018.

ILO. Normlex - Information System on International Labour Standards. Geneva, International Labour Organization, s./d. Disponível em: $<\mathrm{http}: / / w w w . i l o . o r g / d y n /$ normlex/en/f?p=NORMLEXPUB:1:>. Acesso em: 05 mai. 2018.

IPEA. Situação atual das trabalhadoras domésticas no país. Comunicados do Ipea, n. 90. Brasília: $\quad$ IPEA, 2011. Disponível em: $<$ http://www.ipea.gov.br/igualdaderacial/index.php?option=com_content\&view $=$ article\&i 
$\mathrm{d}=668>$. Acesso em: 20 fev. 2018.

IPEA. Retrato das desigualdades de gênero e raça - 1995 a 2015. IPEA: Brasília, 2016. Disponível em: <http://www.ipea.gov.br/retrato/indicadores.html>. Acesso em: 06 mar. 2016.

IPEA. Mulheres e trabalho: breve análise do período 2004-2014. Nota técnica n. 24. Brasília: IPEA, 2016. Disponível em: $<$ http://www.ipea.gov.br/portal/images/stories/PDFs/nota_tecnica/160309_nt_24_mulher _trabalho_marco_2016.pdf $>$. Acesso em: 20 fev. 2018.

JANY-CATRICE, Florence. Economia do cuidado e sociedades do bem viver: revisitar nossos modelos. In: ABREU, Alice Rangel de Paiva; HIRATA, Helena; LOMBARDI, Maria Rosa. Gênero e trabalho no Brasil e na França: perspectivas interseccionais. São Paulo, Boitempo, 2016. p. 267-275.

JANY-CATRICE, Florence; MÉDA, Dominique. Femmes et richesse: au-delà du PIB. Travail, genre et sociétés [online], n. 26, p. 147-171, 2011/12.

JORNAL DA CONSTITUINTE. n. 37. Brasília: 29 de fevereiro a 6 de março de de 1988a. Disponível em: <http://www.senado.gov.br/noticias/ especiais/constituicao25anos /jornal-da-constituinte.htm>. Acesso em: 12 mai. 2018.

JORNAL DA CONSTITUINTE. n. 38. Brasília: 7 a 13 de março de 1988b. Disponível em: $\quad<$ http://www.senado.gov.br/noticias/especiais/constituicao25anos /jornal-daconstituinte.htm>. Acesso em: 12 mai. 2018.

JORNAL DA CONSTITUINTE. n. 39. Brasília: 14 a 20 de março de 1988c. Disponível em: $\quad<$ http://www.senado.gov.br/noticias/especiais/constituicao25anos /jornal-daconstituinte.htm>. Acesso em: 12 mai. 2018.

JORNAL DA CONSTITUINTE. n. 56. Brasília: $1^{\circ}$ a 7 de agosto de 1988d. Disponível em: $\quad<$ http://www.senado.gov.br/noticias/especiais/constituicao25anos /jornal-daconstituinte.htm>. Acesso em: 12 mai. 2018.

JORNAL DA CONSTITUINTE. n. 57. Brasília: 8 a 14 de agosto de 1988e. Disponível em: $\quad<$ http://www.senado.gov.br/noticias/especiais/constituicao25anos /jornal-daconstituinte.htm>. Acesso em: 12 mai. 2018.

JORNAL DA CONSTITUINTE. n. 58. Brasília: 15 a 21 de agosto de 1988f. Disponível em: <http://www.senado.gov.br/noticias/especiais/constituicao25anos /jornal-daconstituinte.htm>. Acesso em: 12 mai. 2018.

KASHIURA JR., Celso Naoto. Sujeito de Direito e Capitalismo. São Paulo: Dobra Universitário. 2014.

KASHIURA JR., Celso Naoto. Apontamentos para uma crítica marxista da subjetividade moral e da subjetividade jurídica. In: KASHIURA JR., Celso Naoto; AKAMINE JR., Oswaldo; MELO, Tarso de. Para a crítica do Direito: reflexões sobre teorias e práticas jurídicas. São Paulo: Outras Expressões, 2015. p. 63-98. 
KERGOAT, Danièle. Divisão sexual do trabalho e relações sociais de sexo. In: HIRATA, Helena et al. (org.). Dicionário Crítico do Feminismo. São Paulo: Editora Unesp, 2009. p. 67-75.

KERGOAT, Danièle. Se battre, disent-elles... Paris: La Dispute, 2012.

KERGOAT, Danièle. O cuidado e a imbricação das relações sociais. In: ABREU, Alice Rangel de Paiva; HIRATA, Helena; LOMBARDI, Maria Rosa. Gênero e trabalho no Brasil e na França: perspectivas interseccionais. São Paulo, Boitempo, 2016. p. 17-26.

KROTOSCHIN, Ernesto. Tratado práctico de Derecho del Trabajo. v. 1. 3. ed. Buenos Aires: Ediciones Depalma, 1977.

KYMLICKA, Will. Filosofia política contemporânea: uma introdução. São Paulo: Martins Fontes, 2006.

LAGARDE, Marcela. De la igualdad formal a la diversidad. Una perspectiva étnica latinoamericana. Anales de la Cátedra Francisco Suárez, v. 37, p. 57-79, 2003.

LANQUETIN, Marie-Thérèse. Chronique juridique des inégalités de salaires entre les femmes et les hommes. Travail, genre et sociétés, Paris, v. 1, n. 15, p. 69-82, 2006.

LAUGIER, Sandra; PAPERMAN, Patricia. Présentation. In: GILLIGAN, Carol. Une voix différente. Paris : Champs Essais, 2008. p. III-XLI.

LAVINAS, Lena. A financeirização da política social: o caso brasileiro. Politika, Rio de Janeiro, n. 2, p. 35-51, jul. 2015. p. 4.

LAVINAS, Lena. É a macroeconomia, idiota! Estudos Feministas, Florianópolis, v. 24, n. 2, p. 621-627, mai./ago. 2016.

LAVINAS, Lena. Armadilhas da igualdade. O Globo, Rio de Janeiro, 5 mar. 2017. Disponível em: <https://oglobo.globo.com/economia/artigo-armadilhas-da-igualdade-porlena-lavinas-21013688>. Acesso em: 26 jun. 2017.

LAVINAS, Lena. The takeover of social policy by financialization: the Brazilian paradox. New York: Palgrave Macmillan, 2017b.

LAVINAS, Lena; COBO, Barbara; VEIGA, Alinne. Bolsa Família: Impacto das transferências de renda sobre a autonomia das mulheres e as relações de gênero. Revista Latinoamericana de Población, v. 6, n. 10, pp. 31-54, 2012.

LAVINAS, Lena; CORDILHA, Ana Carolina; CRUZ, Gabriela Freitas da. Assimetrias de gênero no mercado de trabalho no Brasil: rumos da formalização. In: ABREU, Alice Rangel de Paiva; HIRATA, Helena; LOMBARDI, Maria Rosa. Gênero e trabalho no Brasil e na França: perspectivas interseccionais. São Paulo, Boitempo, 2016. p. 93-109.

LAVINAS, Lena; GENTIL, Denise L. Brasil anos 2000. Novos Estudos, São Paulo, v. 37, n. 2, p. 191-211, mai./ago. 2018.

LEAGUE OF NATIONS. The Versailles Treaty. 28 jun. 1919. Disponível em: $<$ http://avalon.law.yale.edu/imt/partxiii.asp>. Acesso em: 11 mai. 2018. 
LETABLIER, Marie-Thérèse; LANQUETIN, Marie-Thérèse. Concilier travail et famille en France, approches socio-juridiques. Rapport de Recherche. Paris: Centre d'Études de l'Emploi, 2005.

LETOURNEAU, Jocelyn. La caja de herramientas del joven investigador: guía de iniciación al trabajo intelectual. Medellín: La Carreta Editores, 2009.

LYRA FILHO, Roberto. Direito do Capital e Direito do Trabalho. In: SOUSA JÚNIOR, José Geraldo de; AGUIAR, Roberto A. R. (orgs.). Introdução crítica ao Direito do Trabalho. Brasília: Universidade de Brasília, 1993. p. 62-.76

LOCHAK, Danièle. Dualité de sexe et dualité de genre dans les normes juridiques. Lex Electronica, Montréal, v. 15, n. 1, p. 659-690, 2008.

LOCHAK, Danièle. Le droit et les paradoxes de l'universalité. Paris: Presses Universitaires de France, 2010.

LOPES, Cristiane Maria Sbalqueiro. A efetivação do direito à creche no Brasil. Revista do Ministério Público do Trabalho, Brasília, n.40, p. 38-60, set.2010.

LOURO, Guacira Lopes. Nas redes do conceito de gênero. In: LOPES, Marta Julia Marques; MEYER, Dagmar Estermann; WALDOW, Vera Regina. Gênero \& Saúde. Porto Alegre: Artes Médicas, 1996. p. 7- 18.

LUNAS, Alessandra da Costa. Marcha das Margarida. Entrevista concedida a Regina Stela Corrêa Vieira [Skype], 03 mar. 2017.

LUTZ, Bertha. 13 princípios básicos: sugestões ao anteprojeto da Constituição. Rio de Janeiro: Editora Irmãos Pongetti, 1933.

MACHADO, Marta Rodriguez de Assis; LIMA, Márcia. Trabalho doméstico no Brasil: afetos desiguais e as interfaces de classe, raça e gênero. 2016. Disponível em: $<$ http://www.geledes.org.br/wp-content/uploads/2016/01/Texto_Domesticas_

Mascaro_final.pdf?cbe337>. Acesso em: 26.out.2016.

MAEDA, Patrícia. A era dos zero direitos: trabalho decente, terceirização e contrato zero-hora. São Paulo: LTr, 2017.

MAEDA, Patrícia. A contrarreforma na perspectiva da mulher trabalhadora: quando reformar significa precarizar. 08 mar. 2018. Disponível em: $<$ https://www.jorgesoutomaior.com/blog/a-contrarreforma-na-perspectiva-da-mulhertrabalhadora-quando-reformar-significa-precarizar>. Acesso em 15 set. 2018.

MALFORT, Kelli. Mulheres do MST criam novas relações de gênero dentro e fora do movimento. 31.jan.2014. Disponível em: <http://www.mst.org.br/2014/01/31/mulheresdo- mst-criam-novas-relacoes-de-genero-dentro-e-fora-do-movimento.html $>$. Acesso em 5.jul.2016.

MALLET, Estevão. Igualdade e discriminação em direito do trabalho. São Paulo: LTr, 2013.

MARÇAL, Katrine. O lado invisível da economia: uma visão feminista. Trad. Laura 
Folgueira. São Paulo: Alaúde Editorial, 2017.

MARCONDES, Mariana M.; YANNOULAS, Silvia C. Práticas sociais de cuidado e a responsabilidade do Estado. Revista Ártemis [online], v. 13, ed. V, p. 174-186, jan./jul. 2012.

MARCONDES FILHO, Alexandre. Trabalhadores do Brasil! São Paulo: Revista dos Tribunais, 1943a.

MACONDES FILHO, Alexandre. Exposição de motivos. Rio de Janeiro: 1943 b. Disponível em: <https://juslaboris.tst.jus.br/>. Acesso em: 10 mai. 2018.

MARELLA, Maria Rosa. The family economy versus the labour market (or housework as a legal issue). In: CONAGHAN, Joanne; RITTICH, Kerry (ed.). Labour law, work, and family: critical and comparative perspectives. Oxford: Oxford University Press, 2005. p. 157-175.

MARTIN, Claude. Comment le care s'impose-t-il à l'action publique? In: DAMAMME, Aurélie; HIRATA, Helena; MOLINIER, Pascale (coord.). Le travail entre public, privé et intime: comparaisons et enjeux internationaux du care. Paris: Éditions L'Harmattan, 2017. p. 195-206.

MARTINS, Sergio Pinto. Breve histórico a respeito do trabalho. Revista da Faculdade de Direito da Universidade de São Paulo, São Paulo, v. 95, p. 167-176, 2000.

MARUANI, Margaret (dir.). Les nouvelles frontières de l'inégalité : hommes et femmes sur le marché du travail. Paris: La Découverte, 1998.

MARUANI, Margaret; MERON, Monique. Como contar o trabalho das mulheres? França, 1901-2011. In: ABREU, Alice Rangel de Paiva; HIRATA, Helena; LOMBARDI, Maria Rosa. Gênero e trabalho no Brasil e na França: perspectivas interseccionais. São Paulo, Boitempo, 2016. p. 59-69.

MARX, Karl. O Capital. Livro I. São Paulo: Boitempo, 2013.

MATTAR, Laura Davis. Direitos maternos: uma perspectiva possível dos direitos humanos para o suporte social à maternidade. Tese (Doutorado). Faculdade de Saúde Pública da Universidade de São Paulo. Orientadora Carmen Simone Grilo Diniz. São Paulo, 2001.

MCGLYNN, Clare. Work, family, and parenthood: the European Union agenda. In: CONAGHAN, Joanne; RITTICH, Kerry (ed.). Labour law, work, and family: critical and comparative perspectives. Oxford: Oxford University Press, 2005. p. 217-236.

MÉDA, Dominique. Au-delà du PIB: pour une autre mesure de la richesse. Paris : Champs Actuel, 2008.

MÉDA, Dominique. Le travail: une valeur en voie de disparition? 2.ed. Paris: Flammarion, 2010. Não paginado (e-book).

MELO, Hildete Pereira de; PENA, Maria Valéria. A condição feminina e a teoria econômica. Literatura Econômica, Rio de Janeiro, Inpes/Ipea, fev. 1985. 
MELO, Hildete Pereira de; CONSIDERA, Claudio Monteiro; DI SABBATO, Alberto. Os afazeres domésticos contam. Economia e Sociedade, Campinas, v. 16, n. 3, p. 435-454, dez.2007.

MELO, Tarso de. Direito e ideologia: um estudo a partir da função social da propriedade rural. São Paulo: Dobra Universitário, 2013.

MELO, Tarso de. Direitos e lutas sociais: a crítica jurídica marxista entre ambiguidade e resistência. In: KASHIURA JR., Celso Naoto; AKAMINE JR., Oswaldo; MELO, Tarso de. Para a crítica do Direito: reflexões sobre teorias e práticas jurídicas. São Paulo: Outras Expressões, 2015. p. 769-809.

MERCURE, Daniel; SPURK, Jan. O trabalho na história do pensamento ocidental. Petrópolis: Editora Vozes, 2005.

MERCURE, Daniel. Adam Smith: as bases da modernidade. In: MERCURE, Daniel; SPURK, Jan. O trabalho na história do pensamento ocidental. Petrópolis: Editora Vozes, 2005. p. 116-136.

MINAYO, Maria Cecília de Souza; DESLANDES Sueli Ferreira; GOMES, Romeu. Pesquisa Social: teoria, método e criatividade. 28. ed. Petrópolis: Vozes, 2009.

MOLINIER, Pascale. Ética e trabalho do care In: GUIMARÃES, Nadya Araujo; HIRATA, Helena (org.). Cuidado e cuidadoras: as várias faces do trabalho do care. São Paulo: Atlas, 2012. p. 29-43.

MOLINIER, Pascale. Le travail du care. Paris: La Dispute, 2013.

MOLINIER, Pascale. Les écueils de la professionnalisation du care. In: DAMAMME, Aurélie; HIRATA, Helena; MOLINIER, Pascale. Le travail entre public, privé et intime: comparaisons et enjeux internationaux du care. Paris : L'Harmattan, 2017. p. 55-66.

MOLINIER, Pascale; LAUGIER, Sandra; PAPERMAN, Patricia. Qu'est-ce que le care? Souci des autres, sensibilité, responsabilité. Paris: Payot \& Rivages, 2009.

MOLINIER, Pascale; PAPERMAN, Patricia. Descompartimentar a noção de cuidado? Revista Brasileira de Ciência Política, Brasília, n. 18, p. 43-57, set./dez. 2015.

MONTEIRO, Luiz Augusto de Rego et. al. Relatório da Comissão. Diário Oficial dos Estados Unidos do Brasil, Suplemento ao n. 3, 5 de janeiro de 1943. Disponível em: <https://juslaboris.tst.jus.br/>. Acesso em 11. mai. 2018.

MORAES, Maria Lygia Quartim de. Marxismo e feminismo: atividades e diferenças. Crítica Marxista, São Paulo, n. 11, p. 89-97, 2000.

MORRIS, Anne; O’DONNEL, Thérèse. Feminist perspective on employment law. London: Cavendish Publishing Limited, 1999.

MTE. Classificação Brasileira de Profissões. Brasília: Ministério do Trabalho e Emprego, SPPE, 2010.

NASCIMENTO, Amauri Mascaro. Curso de Direito do Trabalho. 23. ed. São Paulo: 
Saraiva, 2008.

NASCIMENTO, Amauri Mascaro. Compêndio de Direito Sindical. 6. ed. São Paulo: LTr, 2009.

NAVES, Marcio Bilharinho. A questão do direito em Marx. São Paulo: Dobra Editorial, 2014.

NEILSON, Brett. Globalização e as biopolíticas do envelhecimento. In: DEBERT, Guita Grin; PULHEZ; Mariana Marques (org.). Desafios do cuidado: gênero, velhice e deficiência. Campinas: Unicamp/IFCH, 2017. p. $29-59$.

NICOLI, Pedro Augusto Gravatá. O sujeito trabalhador e o Direito Internacional Social: a aplicação ampliada das normas da Organização Internacional do Trabalho. Tese (Doutorado). Faculdade de Direito e Ciência do Estado da Universidade Federal de Minas Gerais. Orientadora Daniela Muradas Reis. Belo Horizonte, 2015.

NICOLI, Pedro Augusto Gravatá. Fundamentos de Direito Internacional Social. São Paulo: LTr, 2016.

NOBRE, Marcos. Apontamentos sobre a pesquisa em Direito no Brasil. Cadernos Direito GV, São Paulo. 2009.

NOBRE, Marcos; RODRIGUEZ, José Rodrigo (coord.). Igualdade de direitos entre homens e mulheres. Série Pensando o Direito, n. 11. Brasília: Secretaria de Assuntos Legislativos do Ministério da Justiça, 2009.

NOVAIS, Denise Pasello Valente. Discriminação da mulher e direito do trabalho: da proteção à promoção da igualdade. São Paulo: Dissertação de Mestrado, 2004.

OBSERVATÓRIO DE ANÁLISE POLÍTICA EM SAÚDE. Monitoramento da APS e promoção da saúde aponta que cenário exige cautela. Observatório de Análise Política em Saúde, UFBA, Salvador, 18 abr. 2018. Disponível em: $<$ https://www.analisepoliticaemsaude.org/oaps/noticias/758cfb5c5075ec3eb47daebd3e30 7efd/1/>. Acesso em: 24 abr. 2018.

OIT. Negociação de cláusulas relativas à equidade de gênero e raça 2007/2009. Brasília: Organização Internacional do Trabalho, 2011.

OIT. As boas práticas brasileiras e seguridade social. v.1. Brasília: Organização Internacional do Trabalho, 2012.

OKIN, Susan Moller. Justice, gender and the family. New York: Basic Books, 1989.

OKIN, Susan Moller. Gênero, o publico e o privado. Estudos feministas, Florianópolis, v. 16, n. 2, p. 320, mai./ago. 2008.

OLIVEIRA, Creuza Maria de. Federação Nacional das Trabalhadoras Domésticas. Entrevista concedida a Regina Stela Corrêa Vieira, Brasília, 10 nov. 2016.

OLIVEIRA, Creuza. 'Temos feito malabarismo para conseguir chegar perto dessas trabalhadoras, que foram ensinadas que a mulher não faz política'. Fundo de Investimento 
Social Elas, 12 mai. 2017. Disponível em: <http://www.fundosocialelas.org/noticiasconteudo.asp?cod=376>. Acesso em: 2 fev. 2018.

OLIVEIRA, Francisco de. A economia brasileira: crítica à razão dualista. Estudos Cebrap, São Paulo, n. 2, p. 4-82, 1972.

OLIVEIRA, Francisco de. Crítica à razão dualista/O ornitorrinco. São Paulo: Boitempo Editorial, 2003.

OLIVEIRA, Mauro Márcio. Fontes de Informações sobre a Assembleia Nacional Constituinte de 1987. Quais são, onde buscá-las e como usá-las. Brasília: Senado Federal, Subsecretaria de Edições Técnicas, 1993.

OLIVEIRA VIANNA, Francisco José de. Problemas de direito sindical. Rio de Janeiro: Max Limonad, 1943.

ONU MULHERES. Progress of the World's Women 2015-2016: transforming economies, realizing rights. New York: United Nations, 2015. Disponível em: $<$ http://progress.unwomen.org/en/2015/pdf/UNW_progressreport.pdf $>$. Acesso em: 02 out. 2018.

PAESE, Raquel. O trabalho doméstico e os desafios da sindicalização. Revista Themis Gênero e Justiça - Trabalhadoras domésticas: construindo igualdade no Brasil, Porto Alegre, v. 4, n. 4, p. 55-63, jun.2015.

PAPERMAN, Patricia. Care et discriminations : questions autour du handicap. In: DAMAMME, Aurélie; HIRATA, Helena; MOLINIER, Pascale (coord.). Le travail entre public, privé et intime: comparaisons et enjeux internationaux du care. Paris: Éditions L'Harmattan, 2017. p. 183-193.

PAPERMAN, Patricia; LAUGIER, Sandra (dir.). Le souci des autres: éthique et politique du care. 2. ed. Paris: Éditions de l'École des Hautes études en Sciences Sociales, 2011.

PAPERMAN, Patricia; MOLINIER, Pascale. L'éthique du care comme pensée de l'égalité. Travail, genre et sociétés [online], n. 26, p. 189-193, nov. 2011.

PARREÑAS, Rhacel Salazar. The care crisis in the Philippines: children and transnational families in the new global economy. In: EHRENREICH, Barbara; HOCHSCHILD, Arlie Russel (ed.). Global Woman: nannies, maids, and sex workers in the New Economy. New York: Metropolitan Books, 2003. p. 39-54.

PASUKANIS, Eugeny Bronislanovich. A teoria geral do direito e o marxismo. Rio de Janeiro: Renovar, 1989.

PATEMAN, Carole. O contrato Sexual. Rio de Janeiro: Paz e Terra, 1993.

PEREIRA, Luiza Batista. Federação Nacional das Trabalhadoras Domésticas. Entrevista concedida a Regina Stela Corrêa Vieira [via telefone], 13 abr. 2018. 
PÉREZ OROZCO, Amaia. Del trabajo domestico al trabajo de cuidados. In: CARRASCO, Cristina. Con voz propia: la economía feminista como apuesta teórica y política. Madrid: La Oveja Roja. p. 49-74.

PÉREZ OROZCO, Amaia. Crisis multidimensional y ajuste feminizado. In: CARRASCO, Cristina. Con voz propia: la economía feminista como apuesta teórica y política. Madrid: La Oveja Roja. p. 171-192.

PICCHIO, Antonella. Social reproduction: the political economy of the labour market. Cambridge: Cambridge University Press, 1992.

PICCHIO, Antonella. Introduction. In: PICCHIO, Antonella (ed.). Unpaid work and the new economy: a gender analysis of the standards of living. London: Routledge, 2005a. p. $1-10$.

PICCHIO, Antonella. A macroeconomic approach to an extended standard of living. In: PICCHIO, Antonella (ed.). Unpaid work and the new economy: a gender analysis of the standards of living. London: Routledge, 2005a. p. 11-28.

PICCHIO, Antonella. La economía política y la investigación sobre las condiciones de vida. In: CAIRÓ I CÉSPEDES, Gemma; MAYORDOMO RICO, Maribel (comp.). Por una economía sobre la vida: aportaciones desde un enfoque feminista. Barcelona: Icaria editorial, 2005b. p. 17-34.

PICCHIO, Antonella. La reproducción social y la estructura básica del mercado laboral. In: CARRASCO, Cristina; BORDERÍAS, Cristina; TORNS, Teresa (ed.). El trabajo de cuidados: historia, teoría y políticas. Madrid: Catarata, 2011.p. 122-144.

PINTO, Elisabete Aparecida. Etnicidade, gênero e educação: A trajetória de vida de Dona Laudelina de Campos Mello (1904-1991). 1993. Dissertação (Mestrado em Educação) - Faculdade de Educação, Universidade Estadual de Campinas, Campinas.

PIOVESANA, Claudia Urano Machado; VIEIRA, Regina Stela Corrêa Vieira. Notas sobre o pensamento de juristas no centro da formação do Direito do Trabalho na década de 1940. In: SOUTO MAIOR, Jorge Luiz (org.). Quem é quem no Direito do Trabalho. No prelo.

PISCITELLI, Adriana. Gênero: a história de um conceito. In: SZWAKO, José, ALMEIDA, Heloísa Buarque (orgs.). Diferenças, igualdade. São Paulo: Berlendis \& Vertecchia Ed., 2009. p. 116-148

PLÁ RODRIGUEZ, Américo. Princípios do Direito do Trabalho. 3. ed. São Paulo: Ltr, 2000 .

POLANYI, Karl. A grande transformação: as origens de nosso época. 2. ed. Rio de Janeiro: Campus, 2000

PORTAL BENEDITA DA SILVA. Conheça Benedita da Silva. s./d. Disponível em: $<$ http://www.beneditadasilva.com.br/benedita-da-silva/>. Acesso em: 14 abr. 2018.

RAMALHO, Maria do Rosário Palma. Da autonomia dogmática do direito do trabalho. Coimbra: Almedina, 2000. 
RAWLS, John. Uma teoria da Justiça. São Paulo: Martins Fontes, 1997.

RAWLS, John. Justice as fairness: a restatement. Cambridge: Harvard University Press, 2001.

REIS, Luciana Silva. A modernização crítica do pensamento jurídico brasileiro no século $X X$ : ciência do direito, ensino e pesquisa. São Paulo. 217 f. Tese [doutorado]. Faculdade de Direito da Universidade de São Paulo, 2018.

RIBAULT, Thierry. Cuidadoras domiciliares: que tipo de profissionalização? In GUIMARÃES, N. A. HIRATA, H. S. (org.) Cuidado e cuidadoras: as várias faces do trabalho do care. São Paulo: Atlas, 2012.

RIBEIRO, Raquel Noel. Cuidador de idoso: discussão do processo de regulamentação da profissão pela análise discursiva de audiências públicas. 2015. Tese (Doutorado em Psicologia) - Instituto de Psicologia, Universidade de São Paulo, São Paulo.

RIVAS, Lynn May. Invisible Labors: caring for the independent person. In: EHRENREICH, Barbara; HOCHSCHILD, Arlie Russel (ed.). Global Woman: nannies, maids, and sex workers in the New Economy. New York: Metropolitan Books, 2003. p. $70-84$.

RODRIGUEZ, Lola Pons. El origen de la palabra 'trabajo' es un tortura. El País, Verne, 01 mai. 2018. Disponível em: <https://verne.elpais.com/verne/ 2018/04/24/articulo/1524582530_120514.html>. Acesso em: 04 mai. 2018.

RUBIN, Gayle S. Thinking sex: Notes for a Radical Theory of the Politics of Sexuality. In: VANCE, Carole. Pleasure and Danger: exploring female sexuality. Boston: Rutledge, 1984. p. 267-319.

SAFFIOTI, Heleieth. Emprego doméstico e capitalismo. Petrópolis: Vozes, 1978.

SAFFIOTI, Heleieth. Mulher Brasileira: Opressão e Exploração. Rio de Janeiro: Achiamé, 1984.

SAFIOTTI, Heleieth. A mulher na sociedade de classes: mito e realidade. 3.ed. São Paulo: Expressão Popular: 2013.

SAKAMOTO, Leonardo. O Brasil que usa crianças como empregadas domésticas. UOL Notícias, Blog do Sakamoto, 05 abr. 2013. Disponível em: $<$ https://blogdosakamoto.blogosfera.uol.com.br/2013/04/05/o-brasil-que-usa-criancascomo-empregadas-domesticas/>. Acesso em: 13 mai. 2018.

SANTOS, Judith Karine Cavalcanti. Participação das trabalhadoras domésticas no cenário político brasileiro. In: Fazendo o Gênero 9 - Diásporas, Diversidades, Deslocamentos, 2010, Florianópolis. Anais do Fazendo Gênero 9, Florianópolis, 2010, p. $1-9$.

SANTOS, Natália Neris da Silva. A voz e a palavra do movimento negro na Assembleia Nacional Constituinte (1987/1988): um estudo das demandas por direitos. São Paulo. 205 f. Dissertação [mestrado]. Escola de Direito de São Paulo da Fundação Getúlio Vargas, 2015. 
SANTOS, Silvia Maria Azevedo dos. RIFIOTIS, Theophilos. Cuidadores familiares de idosos dementados: uma reflexão sobre a dinâmica do cuidado e da conflitualidade intrafamiliar. Florianópolis: Laboratório de Estudos de Violência - UFSC, 2006. Disponível em: <http://www.cfh.ufsc.br/ levis/downloads/artigos/CFIDRSDCCIF.pdf> Acesso em: 10 nov. 2017.

SANTOS, Silvia Maria da Silva. Sindicato dos Trabalhadores Domésticos do Município de São Paulo. Entrevista concedida a Regina Stela Corrêa Vieira, São Paulo, 26 jan. 2017.

SANTOS, Vanderlei Guilherme dos. Cidadania e justiça: a política social na ordem brasileira. Rio de Janeiro: Campus, 1979.

SANTOS, Yumi Garcia dos. Mulheres chefes de família entre a autonomia e a dependência: um estudo comparativo entre Brasil, França e Japão. São Paulo. 295 f. Tese [doutorado]. Faculdade de Filosofia, Letras e Ciências Humanas da Universodade de São Paulo, 2008.

SASAKI, Ko. Idoso japonês reincide no crime para fugir do custo de vida e voltar à prisão. Folha de São Paulo [Financial Times], Tóquio, 29 mar. 2016. Disponível em: $<$ http://www1.folha.uol.com.br/mercado/2016/03/1754949-idoso-japones-reincide-nocrime-para-fugir-do-custo-de-vida-e-voltar-a-prisao.shtml>. Acesso em: 22 abr. 2018.

SASSEN, Saskia. Global cities and survival circuits. In: EHRENREICH, Barbara; HOCHSCHILD, Arlie Russel (ed.). Global Woman: nannies, maids, and sex workers in the New Economy. New York: Metropolitan Books, 2003. p. 254-274.

SCHRITZMEYER, Ana Lúcia Pastore. Etnografia dissonante dos tribunais do Júri. Tempo soc. [online]. v. 19, n. 2, p. 111-129, 2007

SCHULTZ LEE, Kirsten. Gender, Care work and the complexity of Family Membership in Japan. Gender and Society, n 24 , p. 647-671, 2010.

SCHUMAHER, Schuma, BRAZIL, Érico V. (orgs). Dicionário Mulheres do Brasil: de 1500 até a atualidade biográfico e ilustrado. Rio de Janeiro: Jorge Zahar, 2000. Não paginado [ebook].

SCOTT, Joan W. Gênero: uma categoria útil de análise histórica. Educação \& Realidade, Porto Alegre, v. 20, n. 2, p. 71-99, jul./dez. 1995.

SCREPANTI, Ernesto; ZAMAGNI, Stefano. An outline oh the history of economic thought. 2. ed. Oxford: Oxford University Press, 2012.

SCRINZI, Francesca. Care. In : RENNES, Juliette. Encyclopédie Critique du Genre. Paris : La Découverte, 2016. p. 106-115.

SECOMBE, Wally. The housewife and her labour under capitalism. New Left Review [online], v. 1, n. 83, p. 3-24, jan./fev. 1974.

SEVERI, Fabiana Cristina. Direitos Humanos das mulheres e a transversalidade de gênero no sistema de Justiça. Revista de Estudos Jurídicos, a. 15, n. 22, p. 325-338, 2011. 
SEVERI, Fabiana Cristina. O gênero da justiça e a problemática da efetivação dos direitos humanos. Direito \& Praxis, Rio de Janeiro, v. 7, n. 13, p. 81-115, 2016.

SEVERO, Valdete Souto; SOUTO MAIOR, Jorge Luiz. Manual da Reforma Trabalhista: pontos e contrapontos. São Paulo: Sensus, 2017.

SILVA. Benedita. Em defesa da classe trabalhadora e dos movimentos populares: discursos pronunciados pela deputadas constituinte Benedita da Silva. Brasília: Câmara dos Deputados, 1988. Disponível em: <http://www.beneditadasilva.com.br/publicacoes/>. Acesso em: 12 mai. 2018.

SILVA, Benedita da. Deputada Federal. Entrevista concedida a Regina Stela Corrêa Vieira, Brasília, 27 mar. 2018.

SILVA, Eliete Ferreira da. Depoimento. Revista Themis Gênero e Justiça Trabalhadoras domésticas: construindo igualdade no Brasil, Porto Alegre, v. 4, n. 4, p. 67-69, jun.2015.

SILVA, Eliete Ferreira da. Sindicato das Trabalhadoras Domésticas de Campinas e Região. Entrevista concedida a Regina Stela Corrêa Vieira [via telefone], 26 jan. 2017.

SILVA, Homero Batista Mateus da. Direito do Trabalho Aplicado, vol. 3: Segurança e medicina do trabalho, trabalho da mulher e do menor. Rio de Janeiro: Elsevier, 2009.

SILVA, Homero Batista Mateus da. Curso de Direito do trabalho aplicado, vol. 7: Direito coletivo do trabalho. 2. ed. Rio de Janeiro: Elsevier, 2010.

SILVA, Homero Batista Mateus da. Comentários à Reforma Trabalhista: análise da Lei 13.476/2017 artigo por artigo. São Paulo: Editora Revista dos Tribunais, 2017.

SILVA, Homero Batista Mateus da. Terceirizar, verbo intransitivo. 31 ago. 2018. Disponível em: <https:/www.facebook.com/professorhomero/photos/a.1994558624100 772/2253945744828724/?type=3\&theater $>$. Acesso em: 03 out. 2018.

SILVA, Walkure Lopes Ribeiro da. Crise de representatividade e participação dos sindicatos em políticas ativas de emprego. São Paulo: Tese de Titularidade da Faculdade de Direito, Universidade de São Paulo, São Paulo.

SMITH, Adam. A riqueza das nações. v. 1. São Paulo: Martins Fontes, 2003.

SOARES, Angelo. As emoções do care. In: GUIMARÃES, Nadya Araujo; HIRATA, Helena (org.). Cuidado e cuidadoras: as várias faces do trabalho do care. São Paulo: Atlas, 2012. p. 44-60.

SOARES, Angelo. O preço de um sorriso: as emoções no trabalho, desafios para a saúde das trabalhadoras e dos trabalhadores. In: OLIVEIRA, Juliana Andrade; MATSUO, Myriam (org.). O trabalho emocional e o trabalho de cuidado. São Paulo: Fundacentro, 2014. p. 13-25.

SORJ, Bila. Trabalho e responsabilidades familiares: um estudo sobre o Brasil: relatório final. Rio de Janeiro: UFRJ, 2004. 
SORJ, Bila. Legislação trabalhista, políticas públicas e igualdade de gênero. In: CFEMEA. Perspectivas e críticas feministas sobre as reformas trabalhista e sindical. Brasília: CEFEMEA, 2006.

SORJ, Bila. Arenas de cuidado nas interações entre gênero e classe social no Brasil. Cadernos de Pesquisa, São Paulo, v. 43, n. 149, p. 478-491, 2013.

SORJ, Bila; FONTES, Adriana. O care como um regime estratificado: implicações de gênero e classe social. In: GUIMARÃES, Nadya Araujo; HIRATA, Helena (org.). Cuidado e cuidadoras: as várias faces do trabalho do care. São Paulo: Atlas, 2012. p. 103-116.

SOS CORPO. Quem somos. Recife: SOS Corpo, 2018. Disponível em: $<$ http://soscorpo.org/quem-somos/>. Acesso em: 17 fev. 2018.

SOUTO MAIOR, Jorge Luiz. História do Direito do Trabalho no Brasil: Curso de Direito do Trabalho, volume 1: parte II. São Paulo, LTr, 2017.

SOUZA-LOBO, Elizabeth. A classe operária tem dois sexos: trabalho, dominação e resistência. 2.ed. São Paulo: Editora Fundação Perseu Abramo, 2011.

STANDING, Guy. O precariado: a nova classe perigosa. Belo Horizonte: Autêntica Editora, 2014.

STEINEM, Gloria. My life on the road. New York: Random House, 2015. Não paginado (e-book).

SUPIOT, Alain et. al. Au-delà de l'emploi: les voies d'une vraie reforme du droit du travail. 2. ed. Paris: Flammarion, 2016. Não paginado [ebook].

SÜSSEKIND, Arnaldo. O cinquentenário da CLT. Revista da Academia Brasileira de Letras Jurídicas, Rio de Janeiro, n. 4, p. 13-24, 1993.

SÜSSEKIND, Arnaldo; LACERDA, Dorval de; VIANA, José de Segadas. Direito brasileiro do trabalho. Rio de Janeiro: Livraria Jacinto Editora, 1943.

TABET, P. La grande arnaque: sexualité des femmes et échange économico-sexuel. Paris: L'Harmattan, 2004

TEIXEIRA, Marilane. O desmonte trabalhista e previdenciário: reinventando novas formas de desigualdades entre os sexos. Análise n. 26. São Paulo: FES, jul. 2017.

TELES, Maria Amélia de Almeida. Breve história do feminismo no Brasil. São Paulo: Brasiliense, 1999.

TEODORO, Maria Regina. Sindicato das Trabalhadoras Domésticas de Campinas e Região. Entrevista concedida a Regina Stela Corrêa Vieira, Campinas, 09 nov. 2017.

THOMAS, Carol. De-constructing concepts of care. Sociology [online], v. 27, n. 4, p. 649-669, nov. 1993. 
THOME, Candy Florencio. O princípio da igualdade em gênero e a participação das mulheres nas organizações sindicais de trabalhadores. 2012. 343 f. Tese (Doutorado em Direito) - Universidade de São Paulo, São Paulo, 2012.

THOMPSON, Edward Palmer. Tempo, disciplina de trabalho e capitalismo industrial. In: THOMPSON, E. P. Costumes em comum. São Paulo: Companhia das Letras, 1998. p. 267-305.

TORNQUIST, Carmen Susana; FLEISCHER, Soraya Resende. Sobre a marcha mundial das mulheres: entrevista com Nalu Faria. Revista de Estudos Feministas, Florianópolis, v. 20, n. 1, p. 291-312, abr. 2012.

TRONTO, Joan. Beyond gender difference to a theory of care. Signs [online], v. 12, n. 4 , p. 644-663, 1987.

TRONTO, Joan. Moral boundaries: a political argument for an Ethic of Care. New York: Routledge, 1993.

TRONTO, Joan. Care as the work of citizens: a modest proposal. In: FRIEDMAN, Mailyn (ed.). Women and Citizenship. Oxford: Oxford University Press, 2005. p. 130145.

TRONTO, Joan. Assistência democrática e democracias assistenciais. Sociedade e Estado, Brasília, v. 22, n. 2, p. 285-308, mai./ago. 2007.

UNITED KINGDOM. Employing someone to work in your home: Au pairs. s./d. Disponível em: $<$ https://www.gov.uk/au-pairs-employment-law/au-pairs $>$. Acesso em 20 fev. 2018.

UGARTEMENDÍA, Cecilia M. Informação verbal, Faculdade de Filosofia, Letras e Ciências Humanas, 8 abr. 2018.

VARGAS, Getúlio. O bem-estar e a saúde das mães e das crianças. Discurso pronunciado no Palácio da Guanabara , em comemoração do Natal. Rio de Janeiro: Biblioteca da Presidência da República, 1939.

VENCATO, Anna Paula; VIEIRA, Regina Stela C. Divisão sexual do trabalho. História do movimento feminista. In: MOTTA, Flávia de Mattos (org). Cotidiano Escolar: Gênero e Docência. Palhoça: Unisul, 2014. pp. 25-47.

VIEIRA, Regina Stela Corrêa. Cuidadoras: a invisibilidade do trabalho de cuidado e o papel do Direito em seu reconhecimento. In: SOUTO MAIOR, Jorge Luiz; GNATA, Noa P. B. (org.). Trabalhos Marginais. São Paulo, LTr, 2013. p. 195-209.

VIEIRA, Regina Stela Corrêa. Saúde e Segurança no Trabalho das Mulheres: A perspectiva de gênero para a proteção e promoção do meio ambiente laboral equilibrado. São Paulo. 221 f. Dissertação [mestrado]. Faculdade de Direito da Universidade de São Paulo, 2014.

VIEIRA, Regina Stela Corrêa. Trabalho das mulheres e feminismo: uma abordagem de gênero do Direito do Trabalho. In: KASHIURA JR., Celso Naoto; AKAMINE JR., Oswaldo; MELO, Tarso de. Para a crítica do Direito: reflexões sobre teorias e práticas 
jurídicas. São Paulo: Outras Expressões, 2015. p. 497-524.

VOSKO, Leah F. Gender, Precarious Work, and the International Labour Code: The Ghost in the ILO Closet. In: FUDGE, Judy; OWENS, Rosemary (ed.). Precarious Work, Women, and the New Economy: The Challenge to Legal Norms. Oñati International Series in Law and Society. Onãti: Hart Publishing, 2006. p. 53-75.

WEST, Robin. Caring for Justice. New York: NYU Press, 1999.

WILLIAMS, Lucy. Poor women's work experiences: gaps in the 'work/family' discussion. In: CONAGHAN, Joanne; RITTICH, Kerry (ed.). Labour law, work, and family: critical and comparative perspectives. Oxford: Oxford University Press, 2005. p. 195-214.

YANNOULAS, Silvia Cristina. Estudos sobre questões de gênero na reforma sindical. In: CFEMEA. Perspectivas e críticas feministas sobre as reformas trabalhista e sindical. Brasília: CEFEMEA, 2006.

YOUNES, Mira; MOLINIER, Pascale. Le «familialisme», au-delà de la fausse conscience: une analyse à partir de récits de travailleuses domestiques (Colombie, Liban). In: DAMAMME, Aurélie; HIRATA, Helena; MOLINIER, Pascale (coord.). Le travail entre public, privé et intime: comparaisons et enjeux internationaux du care. Paris: Éditions L'Harmattan, 2017. p. 89-115.

YOUNG, Iris Marion. Beyond the Unhappy Marriage: a Critique of the Dual Systems Theory. In: SARGENT, Lydia. (ed.) Women and Revolution. Boston: South End, 1981.

YOUNG, Iris Marion. Responsibility and global justice: a social connection model. Anales de la Cátedra Francisco Suarez [online], v. 39, p. 709-726, 2005.

YOUNG, Iris Marion. Responsibility for justice. New York: Oxford University Press, 2011. 
ANEXOS 
Termo de consentimento livre e esclarecido

BRASÍLIA, 10 DE NOVEMBRO DE 2016 (local e data)

$\mathrm{Eu}$, Creuza maria Oliveira portador(a) do Documento de Identidade 0253504799 (RG-BA), concordei em participar, livre e espontaneamente da pesquisa "O cuidado como trabalho: uma conceituação do Direito do Trabalho com base no gênero", concedendo entrevista pessoal e/ou coletiva, virtual e/ou presencial. As entrevistas foram gravadas e transcritas e todo o material coletado será arquivado ao final da pesquisa. Estou ciente de que esse material será analisado e apresentado em forma de tese de doutoramento, relatório de pesquisa ou artigos científicos, em periódicos especializados e congressos. Minha participação foi voluntária, não remunerada e livre de despesas.

A referida pesquisa, financiada pela Fundação de Amparo à Pesquisa do Estado de São Paulo (FAPESP), é desenvolvida pela doutoranda Regina Stela Corrêa Vieira, sob orientação do prof. Homero Batista Mateus da Silva, vinculados ao programa de pósgraduação da Faculdade de Direito da Universidade de São Paulo - USP.

Em caso de dúvidas serei esclarecida(o) pela pesquisadora responsável, por telefone (11) 98303-7536 ou pelo e-mail: regina.vieira@usp.br

O termo é assinado por mim, pelo prof. orientador e pela entrevistadora:

Entrevistada(o):

Orientador:

Entrevistadora:

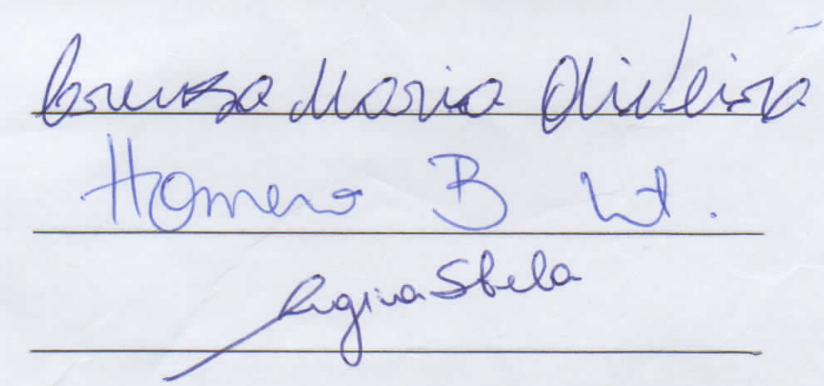




\section{Termo de consentimento livre e esclarecido}

Campinas, 26 de janeivo de 2017 (local e data) Eu, Elut Gerrena. Suhrar. portador(a) do Documento de Identidade $25028897-7$ concordei em participar, livre e espontaneamente da pesquisa "O cuidado como trabalho: uma conceituação do Direito do Trabalho com base no gênero", concedendo entrevista pessoal e/ou coletiva, virtual e/ou presencial. As entrevistas foram gravadas e transcritas e todo o material coletado será arquivado ao final da pesquisa. Estou ciente de que esse material será analisado e apresentado em forma de tese de doutoramento, relatório de pesquisa ou artigos científicos, em periódicos especializados e congressos. Minha participação foi voluntária, não remunerada e livre de despesas.

A referida pesquisa, financiada pela Fundação de Amparo à Pesquisa do Estado de São Paulo (FAPESP), é desenvolvida pela doutoranda Regina Stela Corrêa Vieira, sob orientação do prof. Homero Batista Mateus da Silva, vinculados ao programa de pósgraduação da Faculdade de Direito da Universidade de São Paulo - USP.

Em caso de dúvidas serei esclarecida(o) pela pesquisadora responsável, por telefone (11)98303-7536 ou pelo e-mail: regina.vieira@usp.br

O termo é assinado por mim, pelo prof. orientador e pela entrevistadora:

Entrevistada:

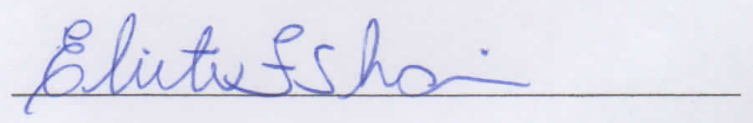

Orientador:

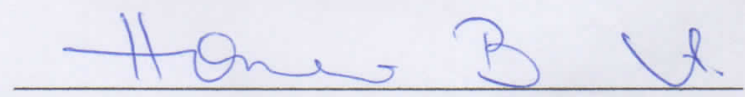

Entrevistadora:

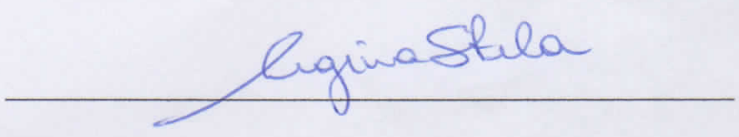




\section{Termo de consentimento livre e esclarecido}

Säe Paulo, 26 de janeiro de 2017 (local e data)

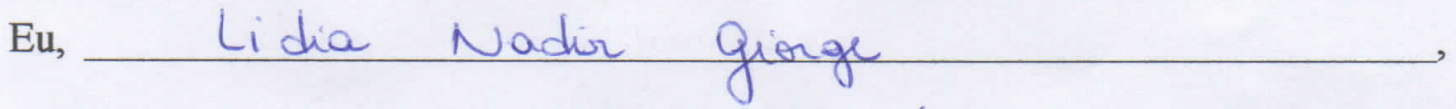

portador(a) do Documento de Identidade RG SSP/SP $5.093 .032-1$, concordei em participar, livre e espontaneamente da pesquisa "O cuidado como trabalho: uma conceituação do Direito do Trabalho com base no gênero", concedendo entrevista pessoal e/ou coletiva, virtual e/ou presencial. As entrevistas foram gravadas e transcritas e todo o material coletado será arquivado ao final da pesquisa. Estou ciente de que esse material será analisado e apresentado em forma de tese de doutoramento, relatório de pesquisa ou artigos científicos, em periódicos especializados e congressos. Minha participação foi voluntária, não remunerada e livre de despesas.

A referida pesquisa, financiada pela Fundação de Amparo à Pesquisa do Estado de São Paulo (FAPESP), é desenvolvida pela doutoranda Regina Stela Corrêa Vieira, sob orientação do prof. Homero Batista Mateus da Silva, vinculados ao programa de pósgraduação da Faculdade de Direito da Universidade de São Paulo - USP.

Em caso de dúvidas serei esclarecida(o) pela pesquisadora responsável, por telefone (11) 98303-7536 ou pelo e-mail: regina.vieira@usp.br

O termo é assinado por mim, pelo prof. orientador e pela entrevistadora:

Entrevistada(o):

Orientador:

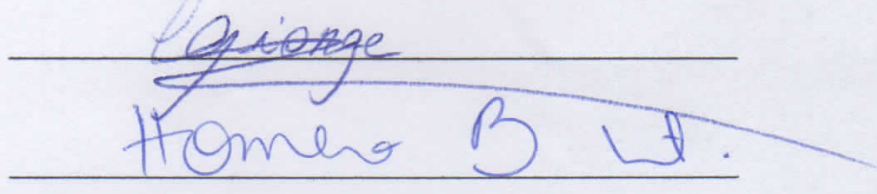

Entrevistadora:

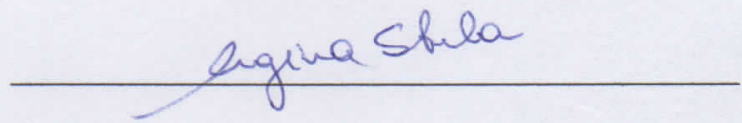




\section{Termo de consentimento livre e esclarecido}

Sáo Paulo $\longrightarrow 26$ de janeiro de 2017 (local e data)

$\mathrm{Eu}$, Silvia maria da Silva Santos

portador(a) do Documento de Identidade SSP/SP $38765461-6$, concordei em participar, livre e espontaneamente da pesquisa " $O$ cuidado como trabalho: uma conceituação do Direito do Trabalho com base no gênero", concedendo entrevista pessoal e/ou coletiva, virtual e/ou presencial. As entrevistas foram gravadas e transcritas e todo o material coletado será arquivado ao final da pesquisa. Estou ciente de que esse material será analisado e apresentado em forma de tese de doutoramento, relatório de pesquisa ou artigos científicos, em periódicos especializados e congressos. Minha participação foi voluntária, não remunerada e livre de despesas.

A referida pesquisa, financiada pela Fundação de Amparo à Pesquisa do Estado de São Paulo (FAPESP), é desenvolvida pela doutoranda Regina Stela Corrêa Vieira, sob orientação do prof. Homero Batista Mateus da Silva, vinculados ao programa de pósgraduação da Faculdade de Direito da Universidade de São Paulo - USP.

Em caso de dúvidas serei esclarecida(o) pela pesquisadora responsável, por telefone (11) 98303-7536 ou pelo e-mail: regina.vieira@usp.br

O termo é assinado por mim, pelo prof. orientador e pela entrevistadora:

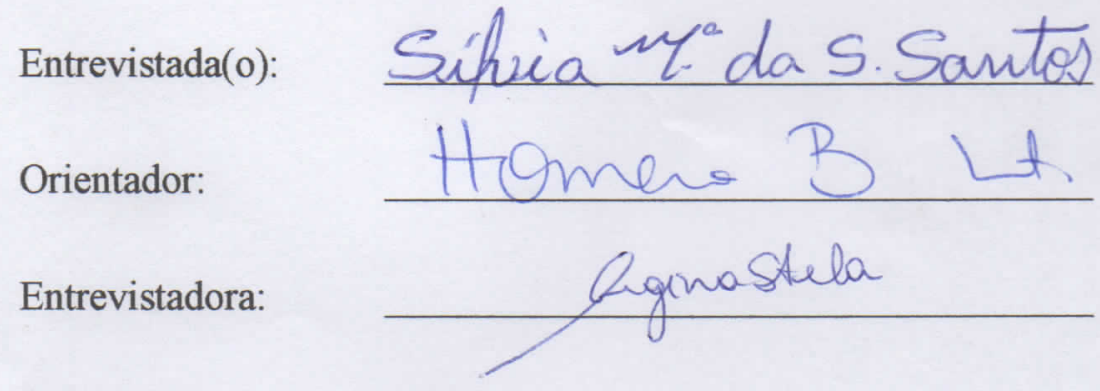




\section{Termo de consentimento livre e esclarecido}

Sáos Paulo, 27 de janeiro 2017 (local e data)

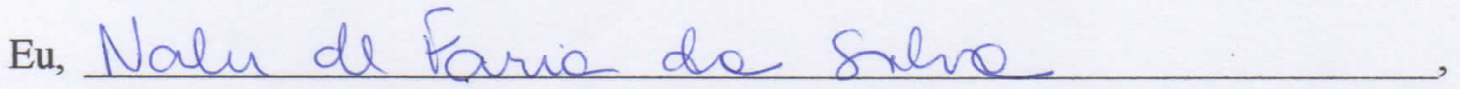

portador(a) do Documento de Identidade $20988997-4$ concordei em participar, livre e espontaneamente da pesquisa "O cuidado como trabalho: uma conceituação do Direito do Trabalho com base no gênero", concedendo entrevista pessoal e/ou coletiva, virtual e/ou presencial. As entrevistas foram gravadas e transcritas e todo o material coletado será arquivado ao final da pesquisa. Estou ciente de que esse material será analisado e apresentado em forma de tese de doutoramento, relatório de pesquisa ou artigos científicos, em periódicos especializados e congressos. Minha participação foi voluntária, não remunerada e livre de despesas.

A referida pesquisa, financiada pela Fundação de Amparo à Pesquisa do Estado de São Paulo (FAPESP), é desenvolvida pela doutoranda Regina Stela Corrêa Vieira, sob orientação do prof. Homero Batista Mateus da Silva, vinculados ao programa de pósgraduação da Faculdade de Direito da Universidade de São Paulo - USP.

Em caso de dúvidas serei esclarecida(o) pela pesquisadora responsável, por telefone (11) 98303-7536 ou pelo e-mail: regina.vieira@usp.br

O termo é assinado por mim, pelo prof. orientador e pela entrevistadora:

Entrevistada(o):

Orientador:

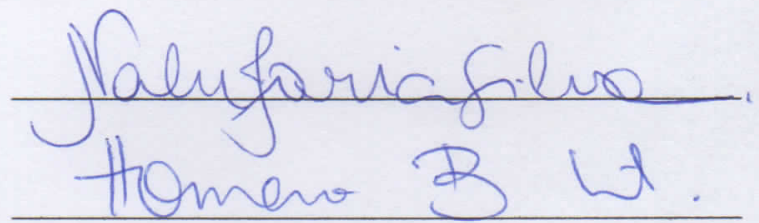

Entrevistadora:

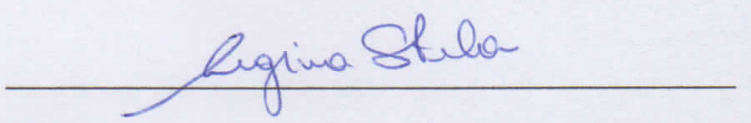




\section{Termo de consentimento livre e esclarecido}

São Paulo, 27 de janeiro de 2017 (local e data)

Eu, Solange Aparecida Caetano, portadora do Documento de Identidade 36.817.2533, concordei em participar, livre e espontaneamente da pesquisa "O cuidado como trabalho: uma conceituação do Direito do Trabalho com base no gênero", concedendo entrevista pessoal e/ou coletiva, virtual e/ou presencial. As entrevistas foram gravadas e transcritas e todo o material coletado será arquivado ao final da pesquisa. Estou ciente de que esse material será analisado e apresentado em forma de tese de doutoramento, relatório de pesquisa ou artigos científicos, em periódicos especializados e congressos. Minha participação foi voluntária, não remunerada e livre de despesas.

A referida pesquisa, financiada pela Fundação de Amparo à Pesquisa do Estado de São Paulo (FAPESP), é desenvolvida pela doutoranda Regina Stela Corrêa Vieira, sob orientação do prof. Homero Batista Mateus da Silva, vinculados ao programa de pósgraduação da Faculdade de Direito da Universidade de São Paulo - USP.

Em caso de dúvidas serei esclarecida(o) pela pesquisadora responsável, por telefone (11)98303-7536 ou pelo e-mail: regina.vieira@usp.br

O termo é assinado por mim, pelo prof. orientador e pela entrevistadora:

Entrevistada:

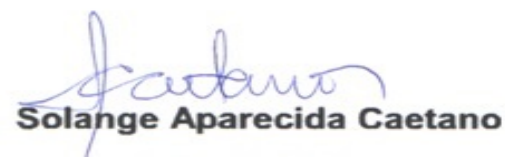

Orientador:

Entrevistadora:

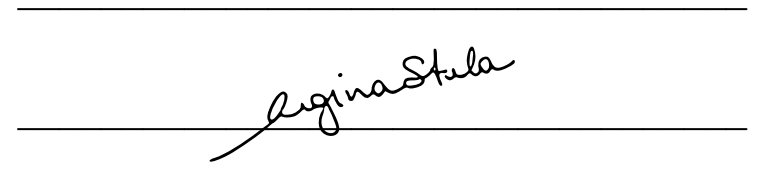




\section{Termo de consentimento livre e esclarecido}

Brasilia, 03 de maio de 2017

Eu, Alessandra da Costa Lunas, portadora do Documento de Identidade 2758837 SSPIDF, concordei em participar, livre c espontaneamente da pesquisa "o cuidado como trabalho: uma conceituaçăo do Direito do Trabalho com base no gênero", concedendo entrevista pessoal e/ou coletiva, virtual e/ou presencial. As entrevistas foram gravadas e transcritas e todo o material coletado setá arquivado ao final da pesquisa. Estou ciente de que esse material será analisado e apresentado em forma de tese de doutoramento, relatório de pesquise ou artigos científicos, em periódicos especializados e congressos. Minha participação fó voluntária, nåăo remunerada e livre de despesas.

A referida pesquisa, financiada pela Fundaçăo de Anipuro à Pesquisa do Estado de São Paulo (FAPESP), é desenvolvida pela doutoranda Rệina Stela Corrêa Vieira, sob orientação do prof. Honero Batista Mateus da Silva, vincúlados ao programa de pósgraduação da Faculdade de Direito da Universidade de Sæo Paulo - USP.

En caso de dúvidas serei esclarecida(o) pela pesquisedora responsável, por telefone (11) 98303-7536 ou pelo e-mail: regina.vieira@usp.br

O termo é assinado por mim, pelo prof. orientadoye êta éitrevistadora:

Entrevistada:

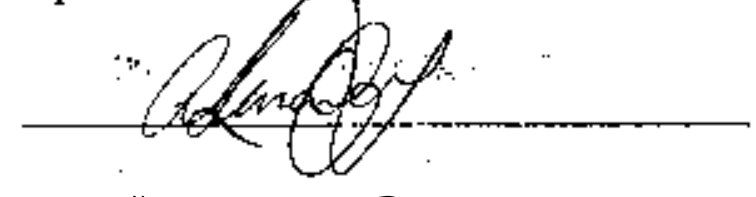

Orientador:

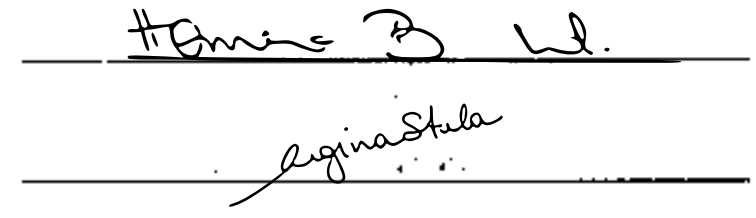

Entrevistadora: 


\section{Termo de consentimento livre e esclarecido}

Campinas - 04 de outubro de 2017 (local e data)

Eu, Glaucia cirstina Candion fraccaro

portador(a) do Documento de Identidade $27918071-8$

concordei em participar, livre e espontaneamente da pesquisa "O cuidado como trabalho: uma conceituação do Direito do Trabalho com base no gênero", concedendo entrevista pessoal e/ou coletiva, virtual e/ou presencial. As entrevistas foram gravadas e transcritas e todo o material coletado será arquivado ao final da pesquisa. Estou ciente de que esse material será analisado e apresentado em forma de tese de doutoramento, relatório de pesquisa ou artigos científicos, em periódicos especializados e congressos. Minha participação foi voluntária, não remunerada e livre de despesas.

A referida pesquisa, financiada pela Fundação de Amparo à Pesquisa do Estado de São Paulo (FAPESP), é desenvolvida pela doutoranda Regina Stela Corrêa Vieira, sob orientação do prof. Homero Batista Mateus da Silva, vinculados ao programa de pósgraduação da Faculdade de Direito da Universidade de São Paulo - USP.

Em caso de dúvidas serei esclarecida(o) pela pesquisadora responsável, por telefone (11) 98303-7536 ou pelo e-mail: regina.vieira@usp.br

O termo é assinado por mim, pelo prof. orientador e pela entrevistadora:

Entrevistada(o):

Orientador:

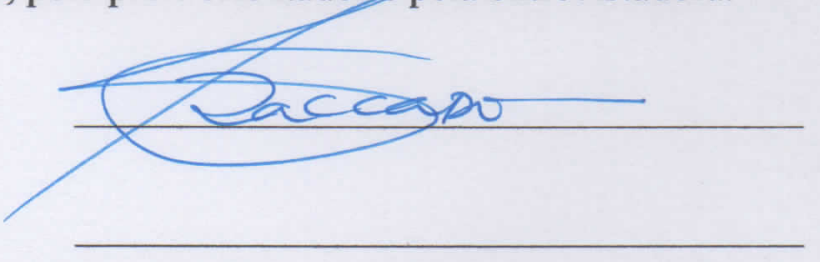

Entrevistadora:

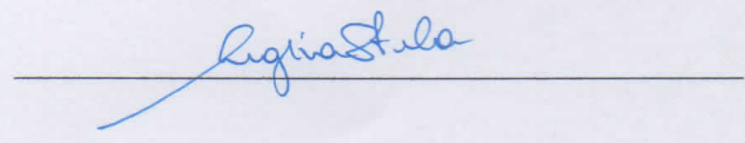


Termo de consentimento livre e esclarecido

Campinas, O9 de novembro de 2017 (local e data)

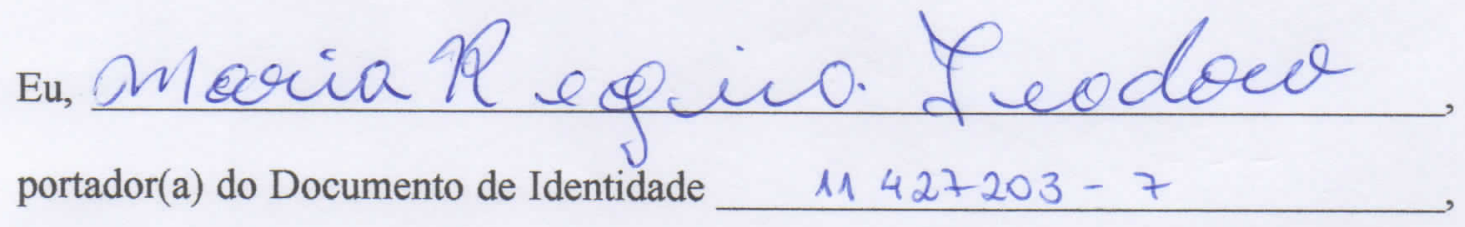
concordei em participar, livre e espontaneamente da pesquisa "O cuidado como trabalho: uma conceituação do Direito do Trabalho com base no gênero", concedendo entrevista pessoal e/ou coletiva, virtual e/ou presencial. As entrevistas foram gravadas e transcritas e todo o material coletado será arquivado ao final da pesquisa. Estou ciente de que esse material será analisado e apresentado em forma de tese de doutoramento, relatório de pesquisa ou artigos científicos, em periódicos especializados e congressos. Minha participação foi voluntária, não remunerada e livre de despesas.

A referida pesquisa, financiada pela Fundação de Amparo à Pesquisa do Estado de São Paulo (FAPESP), é desenvolvida pela doutoranda Regina Stela Corrêa Vieira, sob orientação do prof. Homero Batista Mateus da Silva, vinculados ao programa de pósgraduação da Faculdade de Direito da Universidade de São Paulo - USP.

Em caso de dúvidas serei esclarecida(o) pela pesquisadora responsável, por telefone (11)98303-7536 ou pelo e-mail: regina.vieira@usp.br

$\mathrm{O}$ termo é assinado por mim, pelo prof. orientador e pela entrevistadora:

Entrevistada:

Orientador:

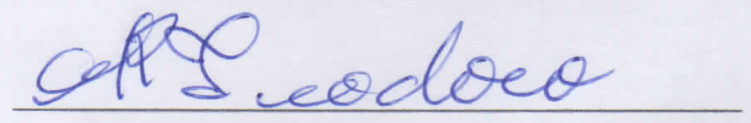

Entrevistadora:
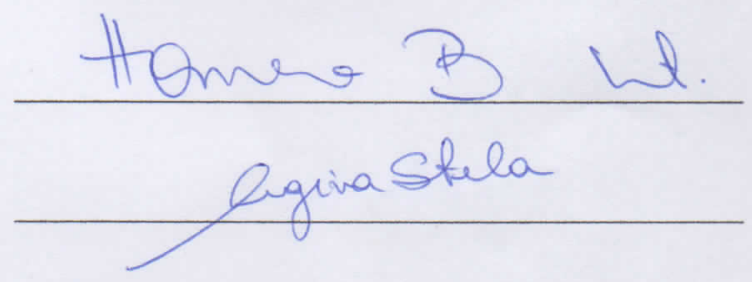


\section{Termo de consentimento livre e esclarecido}

Recife, 13 e abril de 2018 (local e data)

Eu, Luiza Batista Pereira, portadora do Documento de Identidade RG 1603643 SDS/PE, concordei em participar, livre e espontaneamente da pesquisa ${ }^{6} \mathrm{O}$ cuidado como trabalho: uma conceituação do Direito do Trabalho com base no gênero", concedendo entrevista pessoal e/ou coletiva, virtual e/ou presencial. As entrevistas foram gravadas e transcritas e todo o material coletado será arquivado ao final da pesquisa. Estou ciente de que esse material será analisado e apresentado em forma de tese de doutoramento, relatório de pesquisa ou artigos científicos, em periódicos especializados e congressos. Minha participação foi voluntária, não remunerada e livre de despesas.

A referida pesquisa, financiada pela Fundação de Amparo à Pesquisa do Estado de São Paulo (FAPESP), é desenvolvida pela doutoranda Regina Stela Corrêa Vieira, sob orientação do prof. Homero Batista Mateus da Silva, vinculados ao programa de pósgraduação da Faculdade de Direito da Universidade de São Paulo - USP.

Em caso de dúvidas serei esclarecida(o) pela pesquisadora responsável, por telefone (11) 98303-7536 ou pelo e-mail: regina.vieira@usp.br

O termo é assinado por mim, pelo prof. orientador e pela entrevistadora:

Entrevistada:

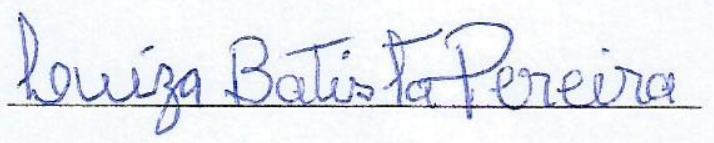

Orientador:

Entrevistadora:

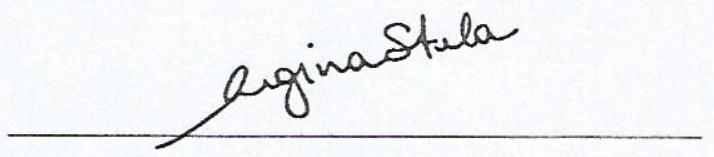




\section{Termo de consentimento livre e esclarecido}

Brasília , 28 de marce de 2018 (local e data)

Eu, Benedita Souza da silva Sampaio portador(a) do Documento de Identidade $\quad 362.933 .347-97$, concordei em participar, livre e espontaneamente da pesquisa "O cuidado como trabalho: uma conceituação do Direito do Trabalho com base no gênero", concedendo entrevista pessoal e/ou coletiva, virtual e/ou presencial. As entrevistas foram gravadas e transcritas e todo o material coletado será arquivado ao final da pesquisa. Estou ciente de que esse material será analisado e apresentado em forma de tese de doutoramento, relatório de pesquisa ou artigos científicos, em periódicos especializados e congressos. Minha participação foi voluntária, não remunerada e livre de despesas.

A referida pesquisa, financiada pela Fundação de Amparo à Pesquisa do Estado de São Paulo (FAPESP), é desenvolvida pela doutoranda Regina Stela Corrêa Vieira, sob orientação do prof. Homero Batista Mateus da Silva, vinculados ao programa de pósgraduação da Faculdade de Direito da Universidade de São Paulo - USP.

Em caso de dúvidas serei esclarecida(o) pela pesquisadora responsável, por telefone (11) 98303-7536 ou pelo e-mail: regina.vieira@usp.br

$\mathrm{O}$ termo é assinado por mim, pelo prof. orientador e pela entrevistadora:

Entrevistada:

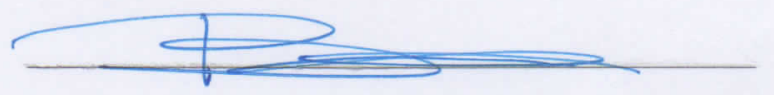

Orientador:

Entrevistadora:

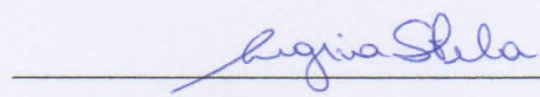




\section{Termo de consentimento livre e esclarecido}

São Paulo, 26 de abril de 2018 (local e data)

eu, Maria do Carmo Godinho Dellado.

portadora do Documento de Identidade 412.447 - SSP. MG concordei em participar, livre e espontaneamente da pesquisa "O cuidado como trabalho: uma conceituação do Direito do Trabalho com base no gênero", concedendo entrevista pessoal e/ou coletiva, virtual e/ou presencial. As entrevistas foram gravadas e transcritas e todo o material coletado será arquivado ao final da pesquisa. Estou ciente de que esse material será analisado e apresentado em forma de tese de doutoramento, relatório de pesquisa ou artigos científicos, em periódicos especializados e congressos. Minha participação foi voluntária, não remunerada e livre de despesas.

A referida pesquisa, financiada pela Fundação de Amparo à Pesquisa do Estado de São Paulo (FAPESP), é desenvolvida pela doutoranda Regina Stela Corrêa Vieira, sob orientação do prof. Homero Batista Mateus da Silva, vinculados ao programa de pósgraduação da Faculdade de Direito da Universidade de São Paulo - USP.

Em caso de dúvidas serei esclarecida(o) pela pesquisadora responsável, por telefone (11)98303-7536 ou pelo e-mail: regina.vieira@usp.br

O termo é assinado por mim, pelo prof. orientador e pela entrevistadora:

Entrevistada:

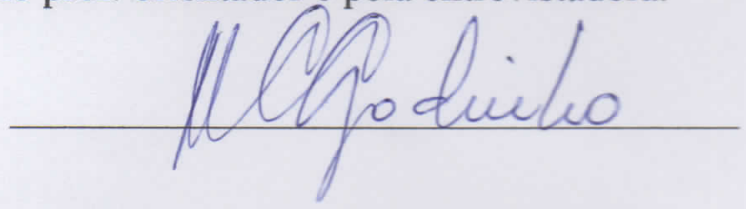

Orientador:

Entrevistadora:

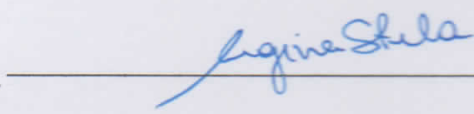




\section{Formulario de consentimiento para entrevistas}

Barcelona, 05 de junio de 2017

Yo, Cristina Carrasco, documento nacional de identidad $43680368 \times$ concuerdo en participar libre y espontáneamente en esta entrevista, parte del proyecto de investigación titulado "O cuidado como trabalho: uma conceituação do Direito do Trabalho com base no gênero". Concuerdo en que esta entrevista sea grabada y/o transcrita y que sus datos sean mantenidos para futuros propósitos de investigación. Yo comprendo que el material de esta entrevista será utilizado sólo para su análisis y que los extractos de la entrevista podrán ser utilizados en presentaciones de conferencias, informes de investigación y/o artículos de revista como resultado de la investigación. Mi participación es voluntaria, gratuita y libre de gastos.

Esta investigación, financiada por la Fundação de Amparo à Pesquisa do Estado de São Paulo (FAPESP), es desarrollada por la doctoranda Regina Stela Corrêa Vieira, bajo la supervisión del Prof. Homero Batista Mateus da Silva, vinculado al programa de posgrado de la Facultad de Derecho de la Universidad de São Paulo.

Para ponerse en contacto con la investigadora: +5511983037536 o regina.vieira@usp.br.

Firma de la entrevistada:

Firma del supervisor:

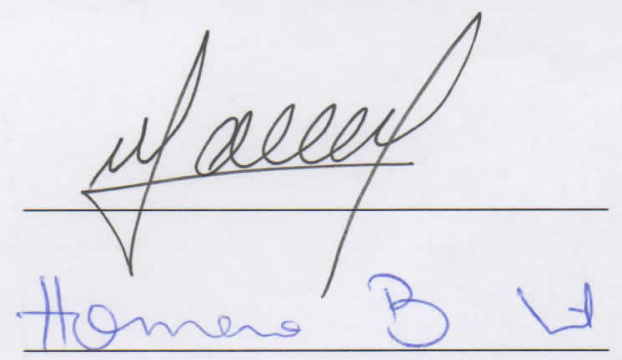

Firma de la entrevistadora:

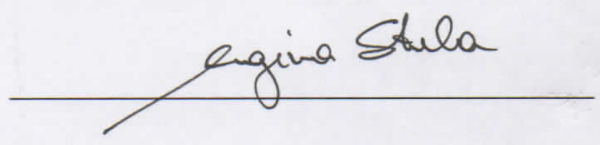




\section{Consent form for interviews}

Canterbury, 12th May 2017

I, Judy Fudge, ID number , agree to take part in this interview, freely and spontaneously, which is part of the research project entitled "Care as labour: a conceptualization of Labour Law based on Gender". I agree for this interview to be tape-recorded and/or transcribed and that its data will be kept for future research purposes. I understand that the material made of this interview will be used only for analysis and that extracts from the interview may be used in any conference presentation, report or journal article developed as a result of the research. My participation is voluntary, unpaid and free of expenses.

This research, funded by the São Paulo Research Foundation (FAPESP), is developed by $\mathrm{PhD}$ candidate Regina Stela Corrêa Vieira, under the supervision of Prof. Homero Batista Mateus da Silva, linked to the University of São Paulo Law School's postgraduate program.

To contact the Researcher: +5511983037536 or regina veira alusp.br.

Signature of interviewee:

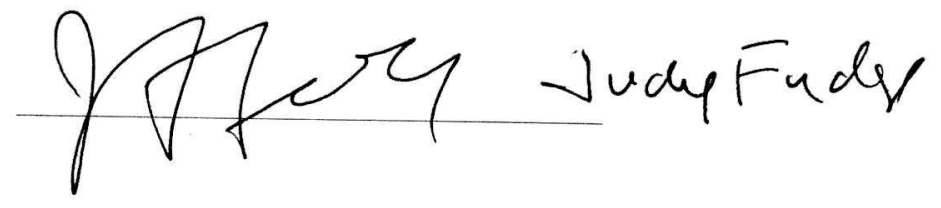

Signature of supervisor:

Signature of interviewer:

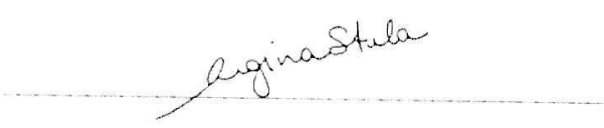

